UNIVERSIDADE DE BRASÍLIA - UnB

INSTITUTO DE GEOCIÊNCIAS - IG

\title{
MODELO CONCEITUAL DO AQUÍFERO FRATURADO DA ÁREA DA JAZIDA DE URÂNIO DE CAETITÉ, BAHIA: IMPLICACÕES PARA O FLUXO SUBTERRÂNEO
}

\author{
DISSERTAC̄̃̃ DE MESTRADO \\ PROGRAMA DE PÓS-GRADUAÇÃO EM GEOCIÊNCIAS APLICADAS
}

Dissertação de mestrado número 86

LILIANE FERREIRA DA SILVA

ORIENTADOR: JOSÉ ELOI GUIMARÃES CAMPOS

BRASÍLIA - DF, 2015. 
UNIVERSIDADE DE BRASÍLIA - UnB

INSTITUTO DE GEOCIÊNCIAS - IG

\title{
MODELO CONCEITUAL DO AQUÍFERO FRATURADO DA ÁREA DA JAZIDA DE URÂNIO DE CAETITÉ, BAHIA: IMPLICACÕES PARA O FLUXO SUBTERRÂNEO
}

\author{
LILIANE FERREIRA DA SILVA
}

Banca Examinadora:

Prof. Dr. José Eloi Guimarães Campos (IG/UnB)

Prof. Detlef Hans Gert Walde (IG/UnB)

Prof. Dr. Gerson Cardoso da Silva Junior (IG/UFRJ) 


\section{DEDICATÓRIA}

Dedico este trabalho a Deus que me fez uma pessoa

Batalhadora e Determinada. 


\section{AGRADECIMENTO}

Agradeço a Deus por tudo que já vivi. Essas experiências me tornaram a pessoa que hoje sou. Tenho muito a aprender ainda e espero ser uma aluna dedicada.

Aos meus pais por toda dedicação. Ao meu esposo que é o grande amor da minha vida.

Ao meu orientador, professor José Eloi, que acreditou nesse projeto, foi um orientador presente e se tornou um querido amigo.

Agradeço ainda as Indústrias Nucleares do Brasil pelos dados fornecidos e a permissão para realizar as atividades de campo, dentro de suas instalações em Caetité.

Finalmente, porém não menos importante, agradeço ao Instituto de Geociências da Universidade de Brasília, pela oportunidade de cursar o Mestrado nesta, que é uma das melhores instituições de ensino do país. 


\section{RESUMO}

A área de estudo é representada pelo Distrito Uranífero de Lagoa Real, localizada no centro-sul do estado da Bahia. Trata-se de região de clima semiárido, quente e seco, com déficit hídrico em todos os meses do ano e elevado índice de aridez. A população rural é especialmente afetada nos períodos de estiagem, pois as principais atividades econômicas na região são a agricultura e a pecuária extensivas em pequenas propriedades, as quais são vulneráveis aos períodos de seca. A água subterrânea representa importante fonte de abastecimento, tendo em vista que a maior parte dos corpos d'água é temporária e só apresenta fluxo nos períodos chuvosos.

O principal sistema aquífero da região é fraturado, e a presença de fluxo se dá através das descontinuidades das rochas, considerando que o maciço rochoso corresponde ao conjunto formado pela massa rochosa e pelas descontinuidades (fraturas, foliações, discordâncias, etc.). Nesse sentido, o objetivo principal desta Dissertação de Mestrado foi desenvolver um modelo conceitual para esse sistema aquífero, a partir da caracterização geotécnica das descontinuidades, na medida em que essas estruturas conferem a porosidade secundária do meio. O sistema aquífero é livre, entretanto, apresenta pontos de estagnação de fluxo compondo compartimentos sem comunicação com áreas adjacentes.

De acordo com a metodologia, da International Society for Rock Mechanics - ISRM, que consiste em caracterizar quali-quantitativamente as descontinuidades do maciço rochoso, scanlines foram construídas, sistematicamente, descrevendo os seguintes parâmetros das estruturas: atitude, espaçamento, persistência, abertura, preenchimento e rugosidade. A partir da análise dos resultados pode-se concluir que existem três famílias de descontinuidades principais que compõem o sistema aquífero, a família com mergulho para NE, para SW-W-NW e subhorizontal. A primeira e a segunda famílias são responsáveis pela recarga, já a terceira responde pela interconexão do aquífero fraturado. A parte superior do maciço apresenta-se bastante fragmentada, entretanto, conforme aumenta a profundidade, predominam estruturas mais penetrativas e com espaçamentos maiores entre si, representadas principalmente pela família NE. Essas anisotropias são fundamentais para o fluxo em zonas mais profundas. As estruturas sub-horizontais persistem até a profundidade de 150 metros, garantindo a interconexão do sistema em todo o maciço analisado.

Com base nas análises dos parâmetros físico-químicos amostrados nos poços, sejam eles: $\mathrm{pH}$, alcalinidade, condutividade, dureza, $\mathrm{Na}, \mathrm{K}, \mathrm{Mg}, \mathrm{Ca}, \mathrm{Ba}, \mathrm{Mn}, \mathrm{Fe}, \mathrm{Al}, \mathrm{SiO}_{2}, \mathrm{SO}_{4}, \mathrm{~F}, \mathrm{Cl}$, $\mathrm{NO}_{3}, \mathrm{~N}$ (amoniacal),e $\mathrm{NO}_{2}$ (em mg/L), assim como $\mathrm{U}$ natural, ${ }^{226} \mathrm{Ra},{ }^{228} \mathrm{Ra}$, Th natural e ${ }^{210} \mathrm{~Pb}$ (em $\mathrm{Bq} / \mathrm{L}$ ), buscou-se estabelecer o diagnóstico hidroquímico do aquífero, através de análises estatísticas, determinação de valores de background e correlação com as estruturas regionais, com o objetivo de auxiliar no entendimento do sistema aquífero. Os resultados mostraram que a distribuição das descontinuidades não foi fator preponderante para a homogeneização das 
concentrações dos parâmetros químicos analisados. Nesse caso, a composição das rochas se revelou fator fundamental. A influência do clima semiárido atua no aumento dos teores totais de sais dissolvidos, especialmente como se observa no caso do cloreto, devido aos longos períodos de estiagem aos quais toda a região é submetida. $O$ teor total de sais dissolvidos já se apresentava em concentrações elevadas, antes do início da atividade de mineração. O mesmo ocorre para os radionuclídeos, em especial o urânio. Além do background já ser elevado, considerando que se trata de região naturalmente anômala, alguns poços apresentam valores de radioatividade bem mais altos. Porém, esses teores estão ligados a natureza da rocha onde o poço está instalado, uma vez que não há indícios de ligação entre esses poços anômalos, e também não há indicadores de comunicação entre eles e os demais poços vizinhos, cujos valores encontram-se dentro do background. Ainda, foram constatados elevados teores de nitrato em toda a região, indicando contaminação antrópica intrinsecamente ligada a dejetos de animais e ao lançamento de esgoto sanitário sem tratamento.

Palavras-chave - Aquífero fraturado, background hidroquímico, urânio. 


\section{ABSTRACT}

The studied area is represented by the uraniferous district of Lagoa Real, located in the center-south of Bahia State, Brazil. The region is set in a semiarid climate context, with hot and dry weather parameters, with hydric deficit along all months of the year and high aridity index. Rural population is affected on drought periods since small agriculture and animal rearing are the main economic activities which are vulnerable in dry seasons. Groundwater represents the main supply source considering that most surface water sources are temporary and only exhibit flow in rainy periods.

The main aquifer system present on the region is fractured, and the presence of groundwater flow occurs through the discontinuities of the rock considering that the rock mass corresponds to the set formed by the rock matrix and all its discontinuities (fractures, foliations, discordances, etc). In this sense, the main purpose of this Master Dissertation was to develop a conceptual model for the aquifer system, through the geotechnical characterization of discontinuities, once these structures allow the secondary porosity of the medium. Hydrochemical data hand out as complement for physical characterization for the behavioral interpretation of the aquifer. The aquifer system is unconfined, however, presents points of stagnation of flow forming compartments without communication with the surrounding areas.

According to the International Society of Rock Mechanics ISRM method, which consist on qualitative and quantitative characterization of discontinuities of rock mass scanlines were constructed, systematically, describing, the following structure parameters: attitude, spacing, persistence, openness, infilling and roughness. From the results analysis it could be concluded that the aquifer system is composed of three discontinuities sets: one set which dips to NE, second set dipping to SW-W-NW and the last set sub-horizontal. The first and second sets are responsible for the aquifer recharge. The third set of discontinuities is related of the fractured aquifer communicability and interconnection. The upper part of the rock mass is highly fragmented, however, as depth increases, more penetrative structures and larger spacing between discontinuities prevails, mainly represented by the NE set. These anisotropies are important for deeper areas recharge, and the existence of water flow. Sub horizontal structures persist up to $150 \mathrm{~m}$ depth, ensuring the system communicability throughout the analyzed rock mass.

Based on the physical-chemical parameters analyses, such as: $\mathrm{pH}$, alkalinity, conductivity, hardness, $\mathrm{Na}, \mathrm{K}, \mathrm{Mg}, \mathrm{Ca}, \mathrm{Ba}, \mathrm{Mn}, \mathrm{Fe}, \mathrm{Al}, \mathrm{SiO}_{2}, \mathrm{SO}_{4}{ }^{2-}, \mathrm{F}^{-}, \mathrm{Cl}^{-}, \mathrm{NO}_{3}$, ammoniacal $\mathrm{N}$, and $\mathrm{NO}_{2}$ (all in $\mathrm{mg} / \mathrm{L}$ ), as well as natural $\mathrm{U},{ }^{226} \mathrm{Ra},{ }^{228} \mathrm{Ra}$, natural $\mathrm{Th}$ and ${ }^{210} \mathrm{~Pb}$ (in $\mathrm{Bq} / \mathrm{L}$ ), it was possible to establish an aquifer hydrochemical diagnosis, by statistical analysis, background determination and correlations with regional structures, with the intention to assist the understanding of the aquifer system. Results showed that discontinuity distribution were not a predominant factor to 
the concentrations homogenization of the chemical parameters. In this case, the composition of the rock was revealed as the most important factor. Still semiarid climate influenced on the total dissolved salt content increment, especially when referred to the chloride due to long dry periods, on which usually the region is submitted. Total dissolved salt content was present on high concentrations, before the beginnings of mining activity. The same occurs with uranium radionuclides. Besides having a high background and considering the anomalous nature of the region, some wells presented high radioactive values. However these high levels were linked to the nature of the rock where the well was installed once there was no connection evidence in between these anomalous wells and there were no connection indicators in between surrounding wells whose values were found within the background. Furthermore, it was identified high nitrate levels in the region evidencing anthropogenic pollution intrinsically connected, to animal waste and untreated sewage release.

Keywords - Fractured aquifer, hydrochemical background, Uranium. 


\section{SUMÁRIO}

\begin{tabular}{|l|c|}
\hline CAPÍTULO I - Introdução & \\
\hline 1.1 Considerações Iniciais & 1 \\
\hline 1.2 Localização da área de estudo & 1 \\
\hline 1.3 Justificativa & 5 \\
\hline 1.4 Objetivos & 7 \\
\hline 1.5 Métodos & 8 \\
\hline 1.6 Organização do Texto & 8 \\
\hline CAPITULO II - Contextualização da área de estudo & 10 \\
\hline 2.1 Geologia Regional & 11 \\
\hline 2.2 Geologia Local & 11 \\
\hline 2.3 Uraninita & 16 \\
\hline 2.4 Geomorfologia Regional e Local & 24 \\
\hline 2.5 Aspectos Meteorológicos & 28 \\
\hline 2.6 Pedologia & 30 \\
\hline 2.7 Hidrografia & 32 \\
\hline 2.8 Mecânica de Rochas & 35 \\
\hline 2.9 Aspectos Socioeconômicos & 37 \\
\hline CAPITULO III - Caracterização do Sistema Aquífero - Modelo Conceitual & 38 \\
\hline 3.1 Introdução & 42 \\
\hline 3.1.1 Propriedades mecânicas das rochas & 42 \\
\hline 3.1.2 Estado de tensões do maciço rochoso & 42 \\
\hline 3.2 Justificativa para uso do método & 43 \\
\hline 3.3 Metodologia & 44 \\
\hline 3.3.1 Orientação & 45 \\
\hline 3.3.2 Persistência & 48 \\
\hline 3.3.3 Espaçamento & 48 \\
\hline 3.3.4 Abertura & 48 \\
\hline 3.3.5 Preenchimento & 49 \\
\hline 3.3.6 Rugosidade & 49 \\
\hline 3.3.7 Percolação & 50 \\
\hline 3.3.8 Número de Famílias & 50 \\
\hline 3.3.9 Tamanho de Blocos & 51 \\
\hline 3.4 Resultados & 51 \\
\hline 3.4.1 Estereogramas e Análise de Fluxo & 52 \\
\hline 3.4.2 Família de Descontinuidades com Mergulho para NE & 58 \\
\hline 3.4.3 Família de Descontinuidades com Mergulho para SW-W-NW & 72 \\
\hline 3.4.4 Família de Descontinuidades Sub-horizontais & 55 \\
\hline 3.4.5 Descrição Comparativa das Famílias de Descontinuidades & 56 \\
\hline 3.4.6 Análise da Distribuição dos Parâmetros no Maciço & 57 \\
\hline CAPíTULO IV - Hidroquímica & 58 \\
\hline 4.1 Introdução & 62 \\
\hline 4.2 Diagnóstico do Aquífero & 67 \\
\hline 4.2.1 Distribuições de Sódio e Cálcio & 68 \\
\hline 4.2.2 Distribuição do Potássio & 75 \\
\hline
\end{tabular}




\begin{tabular}{|l|c|}
\hline 4.2.3 Distribuição do Ferro e Magnésio & 78 \\
\hline 4.2.4 Distribuição do Manganês & 79 \\
\hline 4.2.5 Distribuição do SO 4 & 80 \\
\hline 4.2.6 Distribuição do Cloreto & 82 \\
\hline 4.2.7 Distribuições da Sílica e Alumínio & 86 \\
\hline 4.2.8 Distribuição do Nitrato e Nitrito & 87 \\
\hline 4.2.9 Distribuição do Bário, Fósforo, Flúor e Molibdênio & 89 \\
\hline 4.2.10 Distribuição do Th, 226Ra, 228Ra e 210Pb & 90 \\
\hline 4.3 Determinação de valores de Background na Água Subterrânea & 92 \\
\hline 4.3.1 Urânio & 93 \\
\hline 4.3.2 Nitrato & 97 \\
\hline 4.3.3 Ca - Na - Cl e SO 4 & 98 \\
\hline 4.4 Fluxo & 104 \\
\hline 4.4.1 Poços secos e Produtores & 104 \\
\hline 4.4.2 Controle estrutural & 106 \\
\hline CAPiTULO V - Modelo Conceitual e Proposta para Gestão do Sistema & 111 \\
\hline 5.1 Modelo Conceitual de Fluxo & 111 \\
\hline 5.2 Proposta de Gestão dos Sistemas Aquíferos & 113 \\
\hline 5.2.1 Diagnóstico dos Problemas & 114 \\
\hline 5.2.1.1 Clima Semiárido $\rightarrow$ Déficit Hídrico $\rightarrow$ Salinização das Águas & 114 \\
\hline 5.2.1.2 Background alto para Cálcio - Sódio - Sulfato e Cloretos & 115 \\
\hline 5.2.1.3 Contaminação por Nitrato & 115 \\
\hline 5.2.1.4 Existência de Zonas de Estagnação nos Aquíferos & 115 \\
\hline 5.2.1.5 Anomalias Naturais de Urânio & 115 \\
\hline 5.2.1.6 Prioridades de Uso $\rightarrow$ Abastecimento Público & 116 \\
\hline 5.2.1.7 Falta de Reservatórios de Superfície & 117 \\
\hline 5.2.1.8 Risco Potencial de Contaminação nas Áreas de Lavra de Urânio & 117 \\
\hline 5.2.2 Propostas para Gestão do Sistema de Abastecimento & 117 \\
\hline CAPíTULO VI - Considerações Finais e Conclusões & 123 \\
\hline REFERÊnCIAS BIBLIOGRÁFICAS & \\
\hline
\end{tabular}




\section{LISTA DE FIGURAS}

\begin{tabular}{|l|l|l}
\hline Figura 1.1 - Captação de água em poço tubular profundo na região de Maniaçú, & 2 \\
\hline
\end{tabular} localizada a aproximadamente $30 \mathrm{~km}$ a noroeste de Caetité

\begin{tabular}{|l|l}
\hline Figura 1.2 - Leito do Córrego do Engenho, no mês de Janeiro de 2008, um período de 3
\end{tabular} estiagem prolongada

Figura 1.3 - Mapa de isoietas do estado da Bahia 3

\begin{tabular}{|l|l}
\hline Figura 1.4 - Representação gráfica completa do balanço hídrico climatológico na Estação & 4
\end{tabular} Vitória da Conquista

Figura 1.5 - Localização da área de estudo

Figura 2.1 - Mapa geológico da Província Uranífera da Lagoa Real

Figura 2.2 - Localização dos pontos visitados na atividade de campo

Figura 2.3 - Granito São Timóteo

Figura 2.4 - Gnaisse do Complexo Lagoa Real 18

Figura 2.5 - Foto cava da mina, Corpo III, planos de falha e fraturas sub-horizontais 19

Figura 2.6 - Foto de zona de cisalhamento 20

Figura 2.7 - Gnaisse Zebra 21

Figura 2.8 - Mapa Geológico da mina Cachoeira

Figura 2.9 - Seção geológica da Mina Cachoeira, Caetité 22

Figura 2.10 - Dobras meso a megascópicas na Mina Cachoeira 23

Figura 2.11 - Epidositos junto a área do Complexo mínero-industrial, observados durante atividade de campo em março de 2014

Figura 2.12 -Foto Uraninita

Figura 2.13 -Foto Uraninita

Figura 2.15 - Mapa de relevo do estado da Bahia

Figura 2.16 - Mapa de distribuição da região de clima Semiárido no Brasil

Figura 2.17 - Mapa Pedológico da área estudada

Figura 2.18 - Fotografia onde se pode observar a transição entre solo e rocha, ao longo dos afloramentos expostos na cava da mina

Figura 2.19 - Bacia Hidrográfica do Rio de Contas

Figura 2.20 - Leito do Córrego do Engenho

Figura 2.21 - Ilustração esquemática do aquífero fraturado

Figura 2.22 - Produto Interno Bruto do Município de Caetité

Figura 2.23 - Poço construído para abastecimento da população em São Timóteo

Figura 2.24 - Abastecimento através de poço

Figura 2.25 - Projeto para o desenvolvimento de mudas e irrigação

Figura 2.26 - Projeto para o desenvolvimento de mudas e irrigação 26

Figura 2.27 - Dessalinizador em funcionamento na localidade de São Timóteo

Figura 3.1 - Vista geral do Corpo III - Cava da mina 


\begin{tabular}{|c|c|}
\hline Figura 3.2 - Ilustração das diferentes escalas numa massa de rocha & 46 \\
\hline Figura 3.3 - Exemplos de diversos tipos de descontinuidades & 47 \\
\hline Figura 3.4 - Scanline do levantamento realizado & 47 \\
\hline Figura 3.5 - Distribuição de feições diagnósticas ao longo do plano de descontinuidade & 48 \\
\hline $\begin{array}{l}\text { Figura } 3.6 \text { - Ocorrência de água associada a presença de descontinuidades no maciço } \\
\text { rochoso }\end{array}$ & 50 \\
\hline Figura 3.7 - Classificação de rugosidades utilizados na atividade de campo & 51 \\
\hline Figura 3.8 - Localização dos pontos visitados na atividade de campo & 53 \\
\hline Figura 3.9 - Início da primeira scanline & 54 \\
\hline $\begin{array}{l}\text { Figura } 3.10 \text { - Contorno dos polos obtidos da projeção de } 623 \text { polos, a partir do } \\
\text { levantamento sistemático das estruturas }\end{array}$ & 55 \\
\hline $\begin{array}{l}\text { Figura 3.11- Strikes das descontinuidades, obtidos a partir da projeção dos dados, de } \\
\text { acordo com o levantamento sistemático }\end{array}$ & 55 \\
\hline $\begin{array}{l}\text { Figura } 3.12 \text { - Representatividade das Famílias de descontinuidades identificadas, a partir } \\
\text { do levantamento sistemático das anisotropias do maciço }\end{array}$ & 56 \\
\hline $\begin{array}{l}\text { Figura } 3.13 \text { - Contorno dos polos obtidos da projeção de } 318 \text { medidas, referentes à } \\
\text { família de descontinuidades com mergulho para NE }\end{array}$ & 56 \\
\hline $\begin{array}{l}\text { Figura } 3.14 \text { - Projeção dos strikes referentes à família de descontinuidades com mergulho } \\
\text { para NE }\end{array}$ & 57 \\
\hline $\begin{array}{l}\text { Figura } 3.15 \text { - Contorno dos } 179 \text { polos obtidos da projeção da família de descontinuidades } \\
\text { com mergulho para SW-W-NW }\end{array}$ & 58 \\
\hline $\begin{array}{l}\text { Figura 3.16 - Projeção dos strikes referentes à família de descontinuidades com mergulho } \\
\text { para SW-W-NW }\end{array}$ & 58 \\
\hline $\begin{array}{l}\text { Figura } 3.17 \text { - Projeção do contorno dos } 126 \text { polos, obtidos das descontinuidades sub- } \\
\text { horizontais }\end{array}$ & 59 \\
\hline $\begin{array}{l}\text { Figura } 3.18 \text { - Indícios de que determinada estrutura sub-horizontal é uma falha de } \\
\text { empurrão de baixo ângulo }\end{array}$ & 59 \\
\hline $\begin{array}{llllll}\text { Figura } 3.19- & \text { Parâmetros diagnosticados } & \text { no } & \text { levantamento } & \text { sistemático } & \text { das } \\
\text { descontinuidades, referente a Família NE } & & & & \end{array}$ & 60 \\
\hline 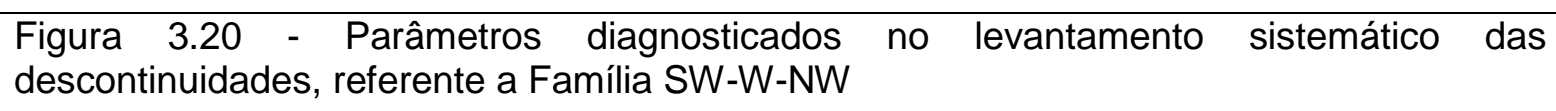 & 61 \\
\hline $\begin{array}{llllll}\text { Figura } 3.21- & \text { Parâmetros diagnosticados no levantamento } & \text { sistemático } & \text { das } \\
\text { descontinuidades, referente a Família Sub-horizontal } & & & \end{array}$ & 61 \\
\hline Figura 3.22 - Projeção estereográfica de todos os dados & 62 \\
\hline $\begin{array}{l}\text { Figura } 3.23 \text { - Parâmetros diagnosticados do levantamento sistemático, do intervalo } \\
\text { superior do Maciço rochoso }\end{array}$ & 63 \\
\hline $\begin{array}{l}\text { Figura } 3.24 \text { - Parâmetros diagnosticados do levantamento sistemático, do intervalo } \\
\text { intermediário do Maciço rochoso }\end{array}$ & 64 \\
\hline $\begin{array}{l}\text { Figura } 3.25 \text { - Parâmetros diagnosticados do levantamento sistemático, do intervalo inferior } \\
\text { do Maciço rochoso }\end{array}$ & 64 \\
\hline $\begin{array}{l}\text { Figura } 3.26 \text { - Proposta de modelo representativo da distribuição das descontinuidades no } \\
\text { maciço }\end{array}$ & 65 \\
\hline 1 & 69 \\
\hline
\end{tabular}




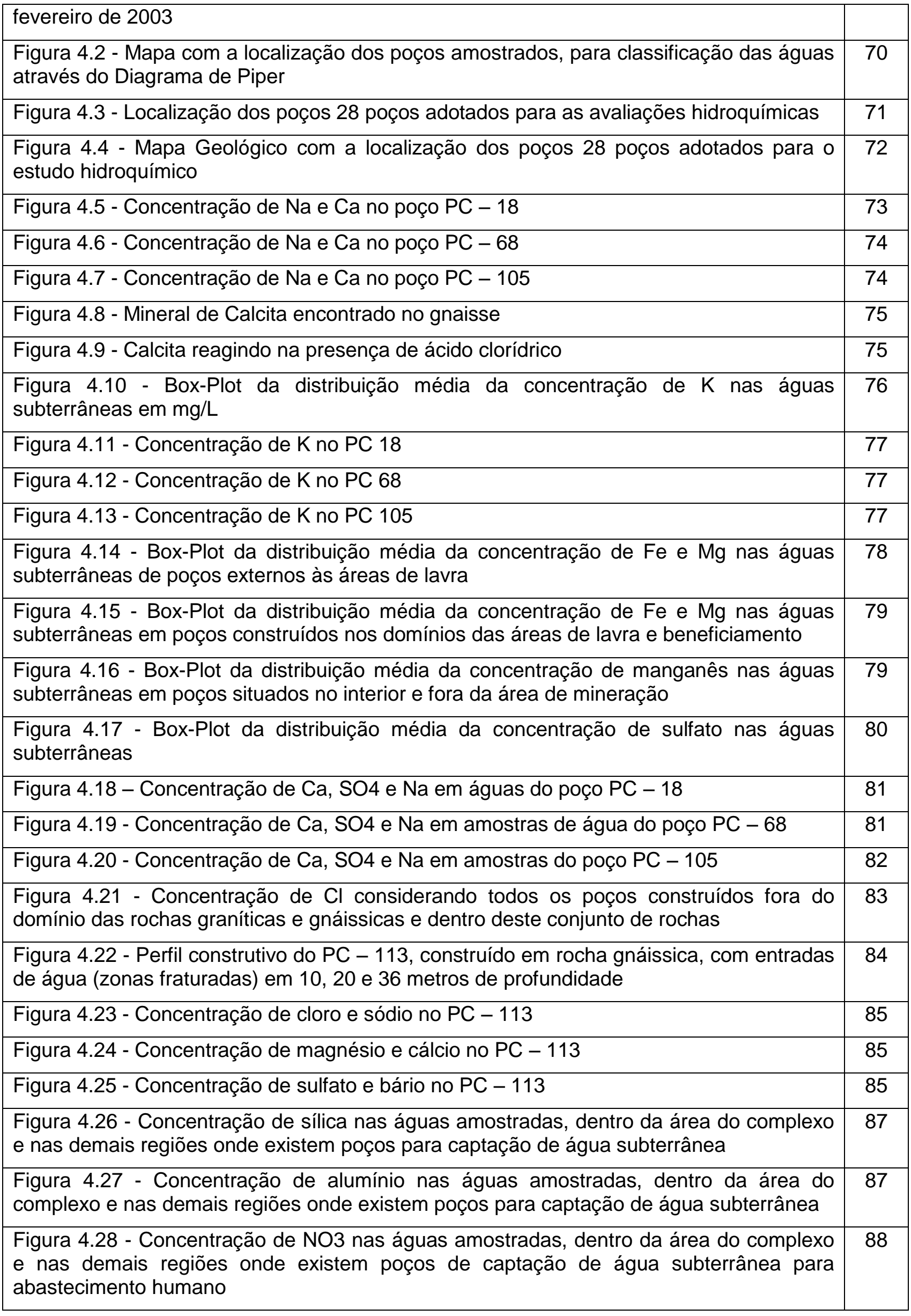


Figura 4.29 - Concentração de NO2 nas águas amostradas, dentro da área do complexo

e nas demais regiões onde existem poços para captação de água subterrânea

Figura 4.30 - Concentrações de $\mathrm{Ba}, \mathrm{P}, \mathrm{F}$ e Mo nas águas amostradas, considerando todos os poços

Figura 4.31 - Distribuição da radioatividade medida nas águas amostradas, considerando todos os poços, para 226Ra, 228Ra, Th natural e $210 \mathrm{~Pb}$

Figura 4.32 - Valores de pH amostrados nas águas subterrâneas, considerando todos os poços e todo o conjunto de dados disponíveis

Figura 4.33 - Concentrações de U natural nas águas amostradas, considerando todos os valores (geral), poços dentro da área do Complexo da INB (dentro), poços fora da área da INB (fora) e todos os poços, porém, desconsiderando as anomalias

Figura 4.34 - Concentrações de U natural nas águas amostradas, considerando os poços dentro dos limites da INB

Figura 4.35 - Concentrações de U natural nas águas amostradas, considerando os poços fora dos limites da INB

Figura 4.36 - Concentrações de U natural nas águas amostradas, considerando todos os poços

Figura 4.37 - Concentrações de U natural nas águas amostradas, considerando todos os poços

Figura 4.38 - Background para a radioatividade do U natural

Figura 4.39 - Baseline para nitrato

Figura 4.40 - Distribuição das concentrações médias de cálcio, sulfato, sódio e cloro obtidas das análises dos poços até o início da operação. Tais resultados representam as análises mais antigas, que serviram de base para a determinação dos valores de background

Figura 4.41 - Distribuição das concentrações médias de cálcio, sulfato, sódio e cloro obtidas das análises históricas englobando todos os poços

Figura 4.42 - Background para o cálcio

Figura 4.43 - Background para o sulfato

Figura 4.44 - Valores de background para o sódio

Figura 4.45 - Background para o cloreto

Figura 4.46 Diagramas de Stiff

Figura 4.47 - Localização dos poços secos e produtores, fruto dos esforços para captação de água na região

Figura 4.48 - Exemplo de perfil construtivo de poços secos. No primeiro caso, PC-08, instalado em rocha granítica e no segundo, PC-73 construído em rocha gnáissica

Figura 4.49 - Exemplos de perfis construtivos de poços produtores. No primeiro caso, PC01 , instalado em rocha gnáissica e no segundo, PC-36 construído no contato entre os gnaisses e o dique de diabásio

Figura 4.50 - Correlação entre a distribuição de U natural e os lineamentos estruturais identificados na região estudada

Figura 4.51 - Correlação entre a distribuição de cloreto com os parâmetros climáticos 109

Figura 4.52 - Lineamentos estruturais identificados baseados no Modelo Digital do Terreno (MDT/ASTER), obtido com posição de luz a N45E e $45^{\circ}$ sob a imagem ASTER 


\begin{tabular}{|l|c|}
\hline $\begin{array}{l}\text { GLOBAL DEM, consultado em 25/07/2015 através do site do Serviço Geológico } \\
\text { Americano (USGS) }\end{array}$ & 113 \\
\hline Figura 5.1 - Bloco diagrama esquemático do sistema de fluxo & 113 \\
\hline Figura 5.2 - Desenho esquemático das descontinuidades ao longo do Riacho das Vacas & 122 \\
\hline $\begin{array}{l}\text { Figura 5.3 - Foto da região de São Timóteo, onde a água subterrânea captada a partir de } \\
\text { poços tubulares profundos é usada para o desenvolvimento da agricultura familiar e } \\
\text { criação de animais }\end{array}$ & 123 \\
\hline Figura 5.4 - Foto de cisterna para captação da água de chuva no semiárido nordestino & 124 \\
\hline Figura 5.5 - Unidade dessalinizadora de São Timóteo & 12 \\
\hline
\end{tabular}




\section{LISTA DE TABELAS}

Tabela 2.1 - Dados de comparação entre uraninita e torianita

Tabela 3.1 - Classificação da persistência das descontinuidades segundo International Society for Rock Mechanics

Tabela 3.2 - Classificação do espaçamento entre as descontinuidades segundo International Society for Rock Mechanics

Tabela 3.3 - Classificação dos tipos

International Society for Rock Mechanics

Tabela 4.1 - Distribuição média da concentração de Na nas águas subterrâneas em mg/L

Tabela 4.2 - Distribuição média da concentração de Na nas águas subterrâneas em mg/L

Tabela 4.3 - Distribuição média da concentração de $\mathrm{K}$ nas águas subterrâneas em $\mathrm{mg} / \mathrm{L}$

Tabela 4.4 - Tratamento estatístico das concentrações médias de cálcio, sulfato, sódio e cloro obtidas das análises de amostras de água oriundas dos poços até o início da operação. Essas são as análises mais antigas, que serviram de base para a determinação do background

Tabela 4.5 - Tratamento estatístico das concentrações médias de cálcio, sulfato, sódio e cloro obtidas das análises históricas englobando todos os poços 


\section{LISTA DE ABREVIATURAS E SIGLAS (EM ORDEM ALFABÉTICA)}

\begin{tabular}{|l|}
\hline ABAS - Associação Brasileira de Águas Subterrâneas. \\
\hline AIE - International Energy Agency - Agência Internacional de Energia. \\
\hline ANA - Agência Nacional de Águas. \\
\hline CBPM - Companhia Baiana de Pesquisa Mineral. \\
\hline CGA/DNPM - Centro de Geofísica Aplicada/Departamento Nacional de Produção Mineral. \\
\hline FEBRABAN - Federação Nacional dos Bancos. \\
\hline IBGE - Instituto Brasileiro de Geografia e Estatística. \\
\hline INB - Indústrias Nucleares do Brasil. \\
\hline ISRM - International Society for Rock Mechanics - Sociedade Internacional de Mecânica de \\
Rochas. \\
\hline USGS - United States Geological Survey - Serviço Geológico Americano. \\
\hline ONU - Organização das Nações Unidas. \\
\hline URA - Unidade de Concentração de Urânio/Complexo Mínero-industrial. \\
\hline
\end{tabular}




\section{INTRODUÇÃO}

\section{$1.1 \quad$ Considerações Iniciais}

A água subterrânea é um recurso cada vez mais escasso e por isto, valioso. Segundo a Agência Nacional de Águas (ANA, 2014) "a possibilidade concreta da escassez de água doce torna-se, cada vez mais, a grande ameaça ao desenvolvimento econômico e à estabilidade política do mundo nas próximas décadas. As disputas pelo uso da água poderão, inclusive, desencadear conflitos e guerras em escala imprevisivel".

A Organização das Nações Unidas (ONU) já alertou: "em 2025, cerca de 2,7 bilhões de pessoas, em todo o mundo, enfrentarão a falta d'água se as populações continuarem a tratá-la como um bem inesgotável. Os países que detêm grandes reservas naturais de água doce como o Brasil - são acompanhados de perto como potenciais fornecedores." Dessa forma percebe-se o valor estratégico deste recurso. Quando se fala de recurso, nos referimos à água doce, própria para o consumo humano desde a sua origem ou após tratamento. Em se tratando de quantidade, é nítida a importância dos aquíferos, pois o volume das águas subterrâneas supera em abundância aproximadamente 100 vezes as águas superficiais, de acordo com a Associação Brasileira de Águas Subterrâneas (ABAS).

Nesse sentido não se deve falar de vulnerabilidade da água subterrânea sem mencionar a necessidade da gestão dos recursos hídricos. Infelizmente, desde os primórdios da civilização a sociedade tem explotado os recursos naturais do planeta com uma visão muito predadora e imediatista. Há pouco tempo começou-se a pensar nas futuras gerações, mas esta tendência ainda é incipiente e sofre com os conflitos de interesses pelo uso destes recursos. Países com grandes populações e economias dinâmicas, tais como China e Estados Unidos ainda resistem em comprometer-se com programas de controle e diminuição da degradação ambiental. No Brasil, o pensamento desenvolvimentista que dominou o país, numa tentativa de atenuar o atraso tecnológico, estrutural e industrial frente aos países desenvolvidos, provocou uma cultura de olhar simplista sobre o meio ambiente e suas questões. Mesmo com a legislação avançada nessa área, o cumprimento dessas leis esbarra na burocracia e ineficiência dos órgãos gestores.

A consequência dessa visão imediatista, que admite o recurso hídrico como inesgotável, é traduzida nos conflitos pelo uso da água e na falta de gestão por parte dos governos e da iniciativa privada. Os usuários competem pelo recurso para diversas finalidades, desde as mais nobres, como o caso do abastecimento humano, até recreação e usos onde praticamente $90 \%$ da água se tornará efluente líquido e não será reaproveitada. 
Esse conflito pelo uso da água ocorre na área de estudo, uma região de clima semiárido onde os recursos hídricos subterrâneos têm grande importância para o abastecimento, tanto da população rural quanto urbana, sendo os aquíferos a única fonte perene de água disponível durante todo o ano (Figura 1.1).

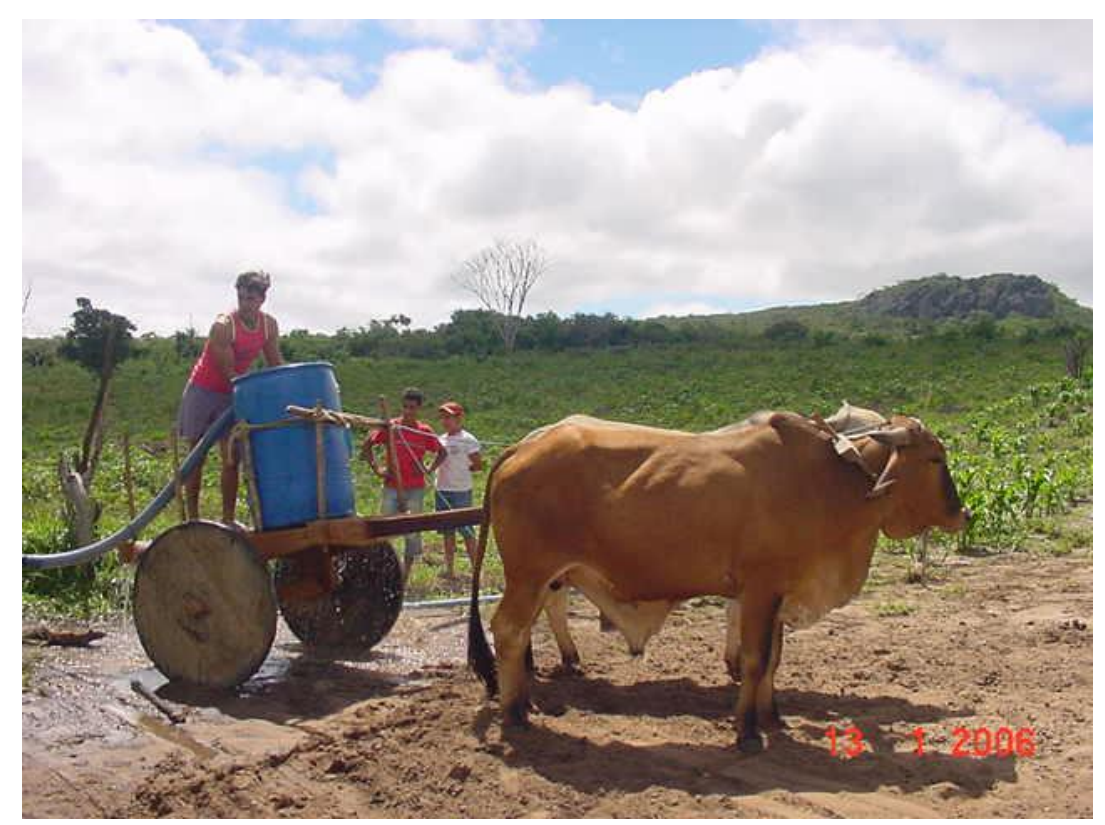

Figura 1.1 - Moradores captando água em poço tubular profundo na região de Maniaçu, localizada a aproximadamente $30 \mathrm{~km}$ a noroeste de Caetité.

A área de estudo é o Distrito Uranífero de Lagoa Real, localizado numa região de relevo suave ondulado a ondulado do centro-sul do estado da Bahia, a cerca de $20 \mathrm{~km}$ a nordeste da cidade de Caetité. Na região, a maior parte das chuvas se concentra em três a quatro meses na estação úmida, acarretando um balanço hídrico negativo, com déficit hídrico no balanço climatológico em todos os meses do ano, além de elevado índice de aridez.

O clima semiárido brasileiro caracteriza-se por ser quente e seco, com estação seca prolongada (Figura 1.2), com distribuição irregular das chuvas e pluviosidade situada entre as isoietas de 500-800 $\mathrm{mm}$ anuais (Figura 1.3).

Baseado nos dados climáticos da estação meteorológica do Instituto Nacional de Meteorologia (INMET), localizada em Vitória da Conquista/BA, foi elaborado o balanço hídrico climatológico. A representação gráfica do balanço hídrico segue as recomendações de Camargo \& Camargo (1993), sendo elaborada a partir do extrato dos dados de precipitação, temperatura e evapotranspiração potencial e evapotranspiração real que possibilita visualizar, além da deficiência e excedente hídrico, as áreas de retirada de água do solo (alteração negativa) e de reposição de água no solo. No caso da região em estudo fica claro que não há excedente hídrico em nenhum mês do ano e apenas retirada, reposição de umidade nos solos e déficit hídrico (Figura 1.4). 


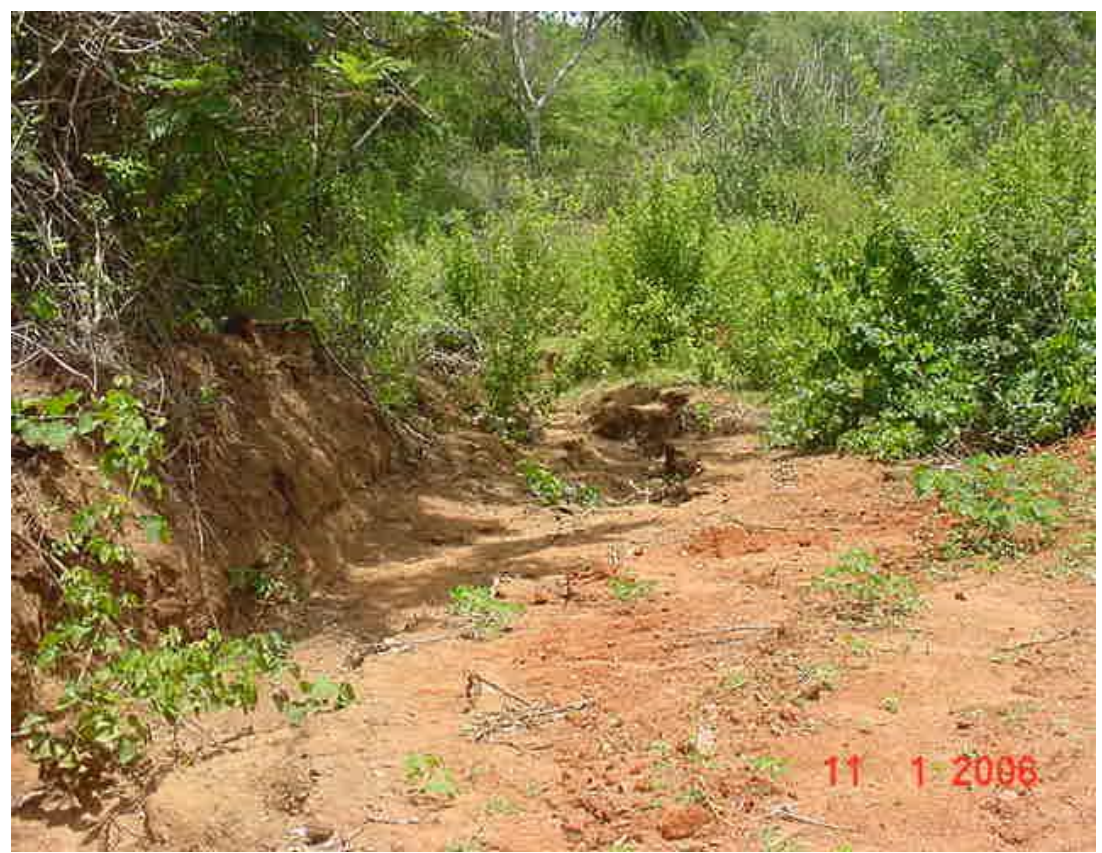

Figura 1.2 - Leito do Córrego do Engenho, no mês de Janeiro de 2008. Mesmo estando na estação chuvosa houve um período de estiagem prolongada.

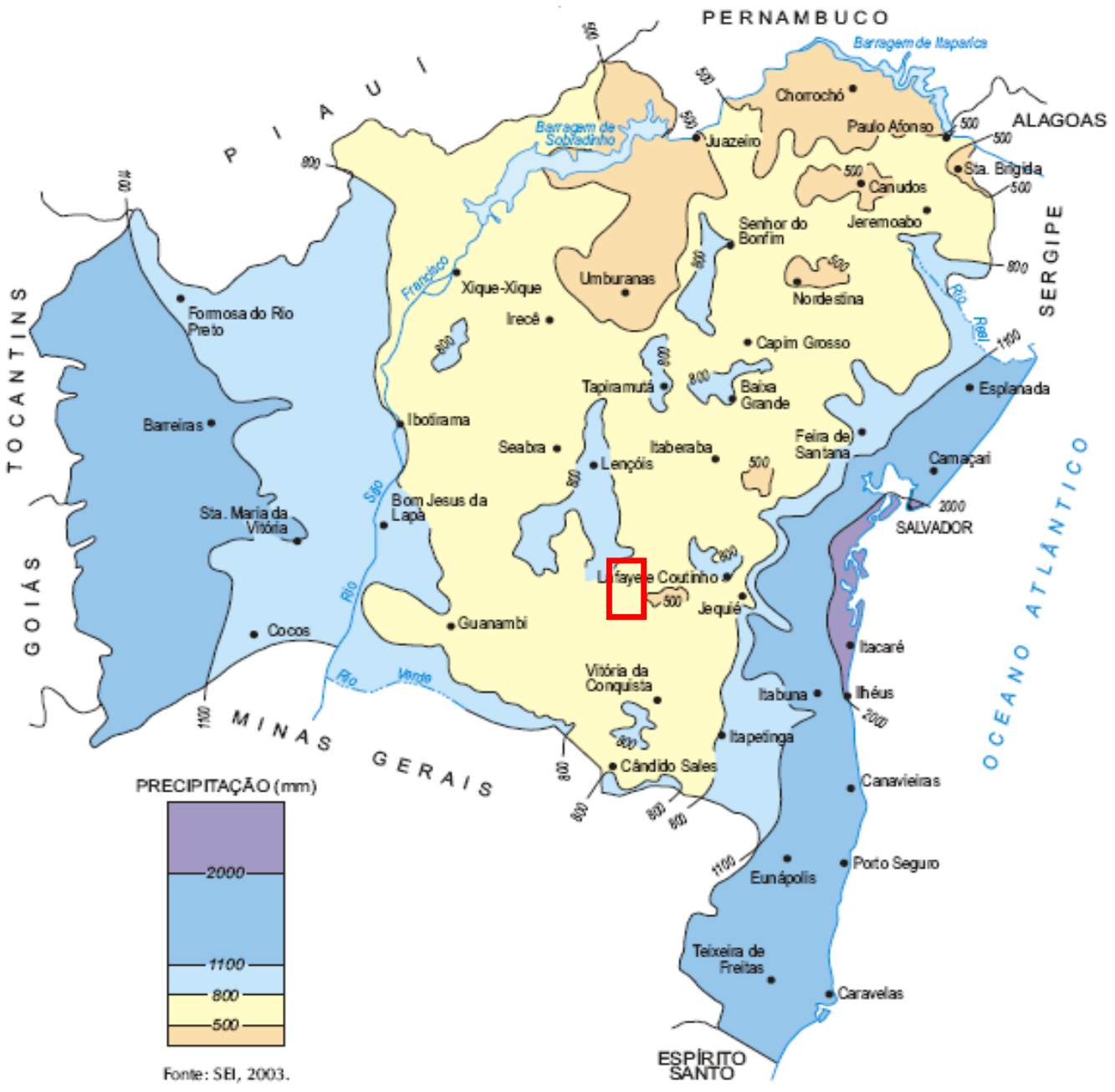

Figura 1.3 - Mapa de isoietas anuais do estado da Bahia. Destacado em vermelho a área em estudo. 


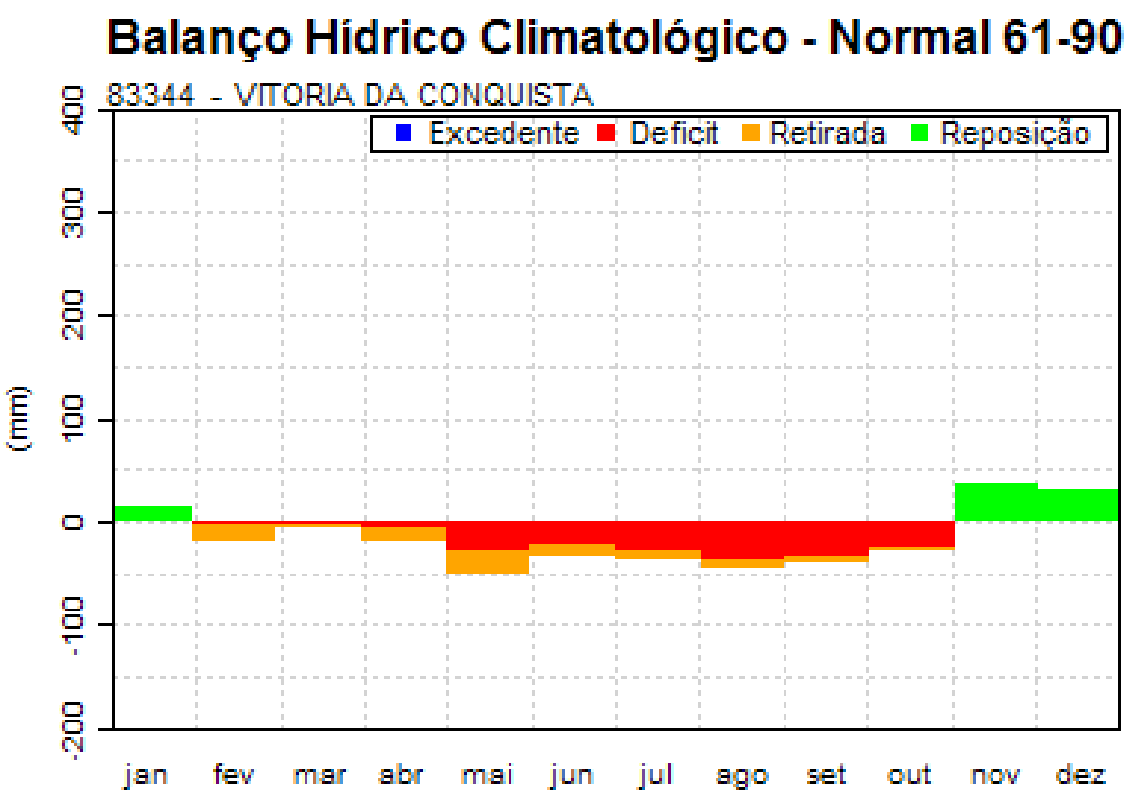

Figura 1.4 - Representação gráfica completa do balanço hídrico climatológico na Estação Vitória da Conquista (INMET, consulta no ano de 2014).

Conforme observado na região, a população rural é especialmente afetada nos períodos de estiagem, por ter renda associada à plantação e criação de animais em pequenas propriedades, atividades bastante vulneráveis aos períodos de seca. Nas regiões mais baixas, nos vales encontram-se muitos poços tubulares que se destinam tanto ao consumo humano, quanto à dessedentação de animais e irrigação de pequenas culturas.

A gestão das múltiplas finalidades de uso da água torna-se fundamental para equacionar os conflitos, devido a escassez dos recursos hídricos, como ocorre no caso dos volumes de água requeridos para abastecimento público e demais finalidades de uso da população, e aqueles necessários a atividade de mineração por exemplo. Em se tratando da mineração de urânio,deve-se considerar ainda que se trata de atividade estratégica para o país. O Brasil possui uma das maiores reservas de urânio do mundo, o que permite o suprimento das necessidades domésticas de longo prazo, e a disponibilização do excedente ao mercado externo, ressaltando ainda o grande potencial de áreas não prospectadas.

Segundo aponta INB (2008), dono da sexta maior reserva do minério no mundo, e com apenas 25 a $30 \%$ do território prospectado (muito embora, especula-se no meio geológico que este percentual não alcance $5 \%$ do território) o país atrai a atenção de empresas privadas nacionais e estrangeiras.

Somam-se a isto, as projeções de aumento da demanda pelo minério em todo o mundo. De acordo com Paul \& Jungblut (2008), "segundo o governo, a construção da usina nuclear de Angra 3 está garantida, como já indica o planejamento do setor elétrico, e as projeções comportam a existência de oito usinas no país até 2030". Especificamente em relação a Angra 3 , cerca de $50 \%$ das obras civis já foram concluídas e a Eletronuclear, empresa subsidiária da estatal Eletrobrás, já iniciou processo para contratação de funcionários para operar essa usina (Eletronuclear, 2014). 
Além da importância econômica das usinas nucleares, existe o interesse ambiental, visto que as usinas nucleares apresentam a inegável vantagem de não emitir gases responsáveis pelo efeito estufa e, por isso, vêm sendo consideradas uma das principais formas para se combater o aquecimento global (Paul \& Jungblut, op cit).

Ainda, de acordo com Kuramoto (2008), "em seu mais recente relatório, a Agência Internacional de Energia (AIE) afirma que, para reduzir em $50 \%$ as emissões de gases responsáveis pelo efeito estufa entre 2010 e 2050, seria necessário adicionar 32 GW de energia nuclear a cada ano à produção mundial". Desta forma, as usinas nucleares ganham reforço para aumentar a sua participação na matriz energética internacional.

Este cenário reforça a importância da gestão dos recursos hídricos subterrâneos na área de estudo, bem como o planejamento e inserção de outras fontes de água para melhor aproveitamento da pluviosidade e escoamento superficial. O abastecimento público é preferencial, entretanto, como única mina de urânio em operação no país a continuidade de suas atividades é estratégica ao desenvolvimento nacional.

A gestão da água subterrânea deve ser precedida do diagnóstico dos aquíferos, à medida que o entendimento da sua formação, dos processos de fluxo e acumulação de água, bem como do tempo necessário à renovação desses recursos hídricos compõem o arcabouço técnico, base para a tomada de decisão pelos gestores. Dessa forma, o conhecimento desse sistema aquífero e a proposição de um modelo que represente o seu comportamento é referência básica para qualquer trabalho posterior, sem o qual nenhuma proposta de gerenciamento poderá ser formulada.

\subsection{Localização da área de estudo}

O distrito uranífero de Lagoa Real foi descoberto durante a execução de uma série de levantamentos geofísicos (gamaespectometria aérea e terrestre), realizados entre 1974 e 1979 , que levaram a identificação de 19 anomalias regionais com elevado potencial para formação de depósitos econômicos. Levantamento posterior mais detalhado de aerogamaespectrometria levou à descoberta de 34 ocorrências uraníferas adicionais. Dentre as áreas mineralizadas está a jazida Cachoeira (anomalia 13), mais conhecida como Complexo Minero-industrial, dentro dos limites do qual se encontra a área de interesse desse estudo (Figura 1.5) (Silva, 2008).

Essa região onde se encontra a URA situa-se no município de Caetité, no sudoeste do Estado da Bahia. O Complexo Mínero-industrial desenvolve atividades de pesquisa, lavra e beneficiamento de minério de urânio (U), objetivando a produção de concentrado de urânio natural sob a forma de Diuranato de Amônio (DUA ou yellow cake) (Cardoso et al., 2009). A produção de yellow cake foi iniciada em 1999 e consiste de planta química, a base de ácido sulfúrico, com capacidade nominal para $400 \mathrm{t} \mathrm{U}_{3} \mathrm{O}_{8} /$ ano. Em 2009, o recorde de produção atingiu $406 \mathrm{t}$ (Pires, 2012). 

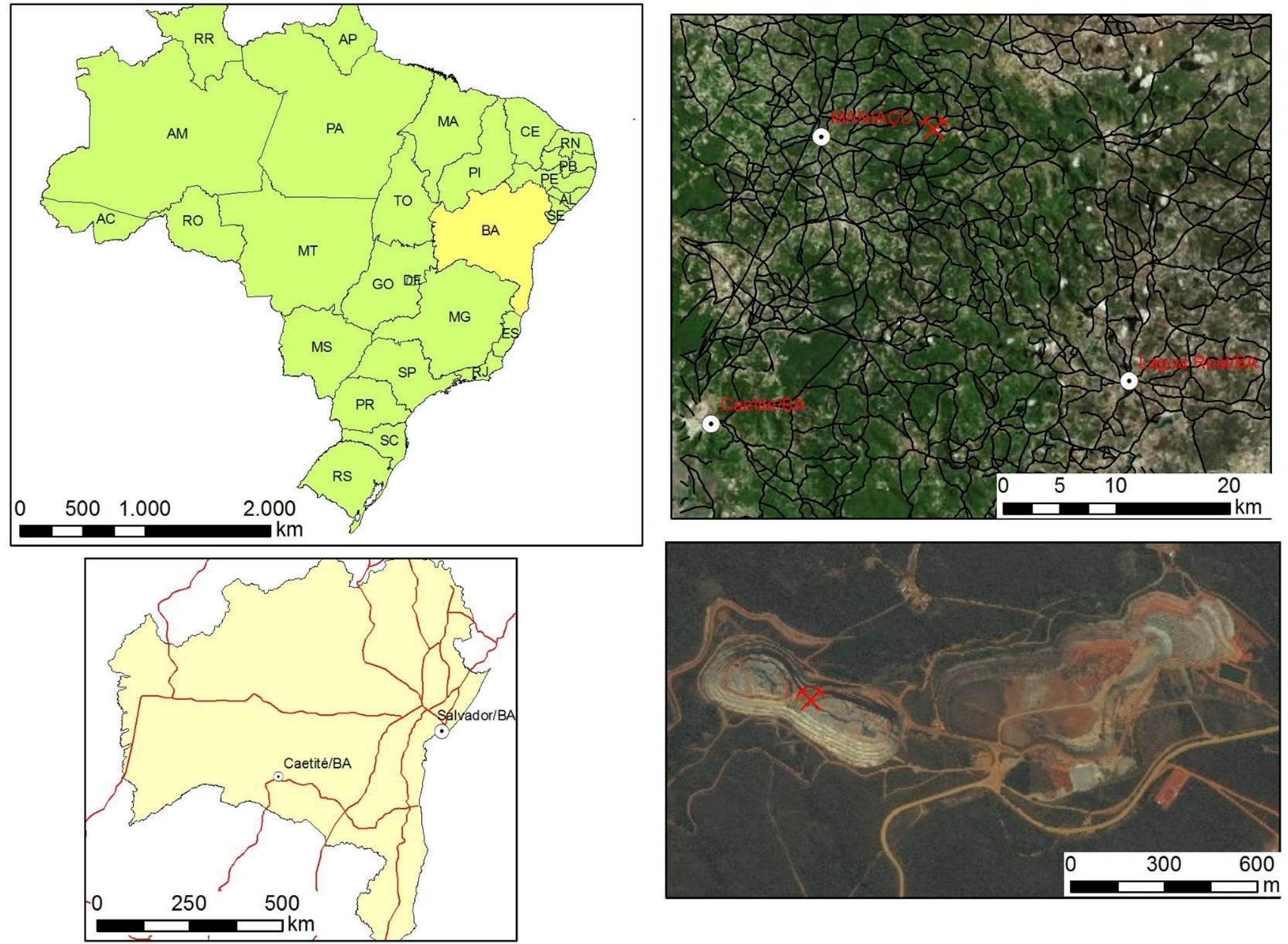

Figura 1.5 - Localização regional e de detalhe da área de estudo. 
O acesso rodoviário principal se dá a partir de Salvador, através da BR 116/030 que interliga as cidades de Vitória da Conquista-Brumado-Caetité, totalizando 740 quilômetros. Já o acesso à Mina Cachoeira, partindo de Caetité, é feito pela BR-122, percorrendo-a por $28 \mathrm{Km}$ até Maniaçu, quando a continuação passa a ser apenas por estrada de terra por $12 \mathrm{Km}$.

As distâncias aproximadas dos núcleos populacionais mais significativos e mais próximos, em torno da área são: Maniaçu e Juazeiro, pertencentes ao Município de Caetité, a 12 km; da sede do município de Lagoa Real, $35 \mathrm{Km}$; São Timóteo, pertencente ao Município Livramento do Brumado, 20 Km (Simões Filho et al., 2008 e Silva, 2008).

\subsection{Justificativa}

De acordo com o que já foi apresentado, a região em que esta dissertação de Mestrado foi desenvolvida está inserida no contexto climático do semiárido nordestino, onde os corpos hídricos superficiais são fortemente afetados pelas condições climáticas. Os rios da região são temporários com fluxo apenas na estação chuvosa. O abastecimento de água das populações rural e urbana é proveniente, preferencialmente, dos recursos hídricos subterrâneos.

Na região a atividade de mineração compete pelo uso da água, tendo em vista que usa a mesma fonte de abastecimento, para o beneficiamento mineral que ocorre até a produção do yellow cake (fase sólida final do processo de concentração do Urânio).

Nesse sentido, torna-se notório o conflito pelo uso dos mananciais subterrâneos. Se por um lado o abastecimento público é prioritário; a mineração, que faz uso de volumes de água significativos é diretamente responsável pelo desenvolvimento econômico da região.

Ainda, existe o conflito entre os recursos destinados a irrigação e dessedentação animal com o consumo e higiene humana.

Finalmente, o conflito mais alarmante relaciona-se a informação disseminada através de diversos veículos de comunicação, ONGs e diversos outros intervenientes, que associam a atividade de mineração com uma possível contaminação da água subterrânea. Essas declarações provocam receio na população leiga quanto ao consumo da água e, em muitos momentos, desencadeiam pânico, tendo em vista que as opções de fontes de abastecimento são escassas.

No que se refere a captação de água pela mineradora, historicamente, os diversos poços para uso do empreendimento minerário foram feitos sem considerar o controle da geologia estrutural. Perfurou-se a procura de água concentrando os esforços nos vales e drenagens onde os primeiros poços eram produtores. Até hoje não se construiu um modelo para o aquífero fraturado presente na área. Isto é fundamental, considerando-se a necessidade de entender a dinâmica das descontinuidades que compõem esse aquífero, no sentido de fazer a gestão desse recurso hídrico e responder aos questionamentos relacionados ao risco potencial de contaminação dessas águas, pela atividade de extração e processamento mineral. 
Esse cenário conflituoso, com múltiplos atores, cujos impactos podem chegar à esfera internacional motivou o desenvolvimento do presente trabalho. Ademais, dessas questões políticas, econômicas e socioambientais, o contexto geológico estrutural e as características geotécnicas das descontinuidades que formam esse sistema aquífero evidenciam a importância de se desenvolver o presente trabalho.

\subsection{Objetivos}

Os objetivos da presente dissertação são:

$\checkmark \quad$ Fazer a caracterização geotécnica das descontinuidades que compõem o aquífero fraturado estudado;

$\checkmark \quad$ Analisar os levantamentos hidrogeoquímicos das águas subterrâneas, de acordo com as amostragens dos poços na área da Mina Cachoeira;

$\checkmark \quad$ Analisar as descrições dos perfis construtivos dos poços com a ocorrência de água ou as causas da improdutividade desses poços;

$\checkmark \quad$ Elaborar modelo conceitual do aquífero, com base na caracterização do meio físico e na hidroquímica;

$\checkmark \quad$ Propor ações para a gestão dos recursos hídricos subterrâneos integrados aos superficiais no contexto econômico e socioambiental.

\subsection{Métodos}

O detalhamento da metodologia que embasou o desenvolvimento desta dissertação será exposto mais adiante em detalhes durante o desenvolvimento de cada capítulo, entretanto, é apresentada síntese com o intuito de situar o leitor no contexto geral do trabalho:

1. Levantamento bibliográfico - foram levantadas informações sobre a geologia, geologia estrutural, pedologia, geomorfologia e climatologia, com o intuito de caracterizar fisicamente a região. Além disso, foram levantados os critérios para tratamento e análise dos dados referentes aos parâmetros físico-químicos das águas subterrâneas disponibilizados pela INB, concernentes aos perfis de descrições dos poços para abastecimento, bem como métodos para realizar o levantamento sistemático das descontinuidades. Conforme o conteúdo for abordado, a revisão bibliográfica teórica e metodológica relacionada será introduzida, de modo a facilitar a contextualização e entendimento por parte do leitor;

2. Discussão de critérios - com base no diagnóstico físico e metodológico fruto do levantamento bibliográfico, procurou-se estabelecer as premissas que balizaram o desenvolvimento da pesquisa. Nessa etapa estabeleceu-se a forma de abordagem dos temas, com foco nos resultados, inclusive identificando as etapas fundamentais para a construção do modelo conceitual do aquífero, de acordo com os dados disponíveis. Essa etapa encontra-se distribuída ao longo do texto conforme os assuntos são abordados; 
3. Atividades de campo - durante as visitas a campo efetuou-se o reconhecimento da área, a avaliação da geologia regional e local e a caracterização das descontinuidades, nos locais com afloramento de rocha dentro dos limites do empreendimento da INB. Obteve-se a maior parte dos dados geológicos levantados na área de exposição de rocha, que correspondem as cavas da mina, e em menor volume em locais onde houve o desvio do canal dos rios temporários, parte da logística necessária a atividade de mineração;

4. Caracterização física do sistema aquífero - esta etapa compreendeu o diagnóstico do meio físico, a partir da caracterização das descontinuidades, igualmente da concepção dos estereogramas, da determinação das características hidráulicas da zona não saturada e da definição dos parâmetros hidrodinâmicos e dimensionais do sistema fraturado;

5. Caracterização hidroquímica do sistema aquífero - nesta fase os parâmetros físico-químicos, investigados sistematicamente pela INB, por meio de amostragens das águas dos poços de abastecimento, foram analisados com foco em identificar os valores de background e eventuais anomalias. Esse estudo fundamentou as interpretações relativas à ocorrência de mistura de águas, a existência de zonas de estagnação, e finalmente, os sistemas de fluxo da água subterrânea;

6. Elaboração do Modelo Conceitual do Aquífero Fraturado - em conformidade com os resultados, nesse estágio construiu-se o modelo conceitual do sistema aquífero fraturado em questão. Essa conceituação buscou descrever fisicamente o aquífero, salientando o sistema de fluxo observado, de acordo com a comunicação das descontinuidades e a variação dos parâmetros analisados, conforme a profundidade. Ademais, foram confeccionadas ilustrações (por exemplo, na forma de bloco-diagrama) que visam esclarecer o modelo estabelecido para o regime hídrico subterrâneo. Estas ilustrações devem convergir todos os resultados obtidos, que discriminam o comportamento desse aquífero;

7. Formulação de proposta para gestão do sistema aquífero - nessa etapa foram identificados os principais conflitos pelo uso da água, desde competição de diversos tipos de usos até o potencial de contaminação das águas subterrâneas com isótopos radioativos, em decorrência da atividade de mineração. Essa análise considerou critérios fundamentais a gestão dos aquíferos, tais como: os diversos cenários de conflito identificados, o domínio do clima semiárido da região sobre o regime de chuvas e o modelo conceitual proposto. A partir desses fundamentos foi desenvolvida a proposta preliminar de gestão dos recursos hídricos dessa região. Ressalta-se que essas recomendações para gerenciamento desses recursos representam uma proposição inicial, considerando-se os diversos setores públicos e privados envolvidos. Para que culmine em êxito, faz-se necessária a intervenção governamental no sentido de arbitrar as disputas de forma isonômica e transformar a proposta de gestão dos recursos hídricos num mecanismo que possa ser implantado na região;

8. Elaboração do artigo e submissão para publicação. 


\subsection{Organização do Texto}

Este texto apresenta-se distribuído em 7 capítulos, divididos de acordo com o tema central tratado em cada um. O presente capítulo apresenta uma introdução ao tema, a localização da área, as justificativas para o trabalho, os objetivos e a síntese da metodologia adotada.

O Capítulo 2 apresenta a revisão bibliográfica relacionada à caracterização física, regional e local, da área. A contextualização da geologia (regional e local, tectônica e estrutural), pedologia, geomorfologia, aspectos climáticos e geotécnicos, são o alicerce para a construção do modelo conceitual do aquífero estudado. Nessa fase, tanto dados secundários, quanto aqueles obtidos durante as atividades de campo são apresentados.

O Capítulo 3 inicia com uma revisão bibliográfica sucinta, visando justificar a metodologia adotada, de acordo com as características da área analisada. Em seguida expõem-se toda a caracterização das descontinuidades, desde os métodos até a execução das atividades na área e os resultados, acompanhadas da caracterização hidrodinâmica, a partir dos perfis construtivos dos poços, testes de bombeamento e recuperação. Por último, a individualização das distintas famílias de estruturas e sua importância para o fluxo de água. Este capítulo é apresentado na forma de artigo, já enviado para publicação.

O Capítulo 4 trata da caracterização hidrogeoquímica do sistema aquífero. Trata-se da construção dos gráficos com a variação dos parâmetros físico-químicos analisados ao longo do tempo. Posteriormente exibe as análises desses dados, abrangendo desde a identificação dos valores de background, até as eventuais anomalias. Finalmente discorre sobre a classificação das águas utilizando o Diagrama de Stiff.

No Capítulo 5 os conflitos pelo uso da água na região são abordados. A partir de seu diagnóstico elabora-se uma proposta de gerenciamento desses recursos hídricos.

Por fim, o Capítulo 6 apresenta uma análise crítica da dissertação como um todo e em seguida elenca os principais resultados desse trabalho. 


\section{CAPÍTULO II}

\section{CONTEXTUALIZAÇÃO DA ÁREA DE ESTUDO}

De acordo com Chaves (2013) a única mina de urânio atualmente em operação na América Latina é a Mina Cachoeira, na Província Uranífera de Lagoa Real. Essa região foi descoberta em 1977, durante levantamentos aerogeofísicos na região do Espinhaço, no denominado Projeto Urandi, Centro de Geofísica Aplicada/Departamento Nacional de Produção Mineral (CGA/DNPM), contratado pela Nuclebrás em 1975 e cobrindo uma área de 6.000 km² (Pires, 2012).

Posteriormente, em 1979, foram detectadas 115 anomalias. Em 1981, efetuou-se convênio entre a Nuclebrás e a Companhia Baiana de Pesquisa Mineral (CBPM), para a realização de mapeamento geológico em escala de 1/25.000, numa extensão de 1.150 km², identificando jazidas e anomalias. No período compreendido entre os anos de 2010 e 2011 essa área foi reduzida para $64 \mathrm{~km}^{2}$, graças ao Projeto Maniaçú (CBPM-INB), que contou com levantamentos de geologia e geofísica (gamaespectrometria e magnetometria) terrestres, resultando na descoberta de 17 anomalias.

Essa área constitui o distrito uranífero mais importante para a INB, onde se encontra a Mina Cachoeira (anomalia 13) e quatro jazidas dormentes (03-Rabicha, 06-Laranjeiras, 08Quebradas e 09-Engenho), com reserva total estimada em cerca de $90.000 \mathrm{t} \mathrm{U}_{3} \mathrm{O}_{8}(60.000 \mathrm{t}$ $\mathrm{U}_{3} \mathrm{O}_{8}$ de reservas medidas + indicadas e 30.000 t $\mathrm{U}_{3} \mathrm{O}_{8}$ de reservas inferidas). Aguardam definição 33 anomalias adicionais (Pires, 2012).

A contextualização apresentada aqui focará principalmente os aspectos físicos, que caracterizam a região e são fundamentais para o entendimento do sistema aquífero estudado, incluindo a integração entre os meios geológico, topográfico, meteorológico, pedológico e geomorfológico.

\subsection{Geologia Regional}

Segundo Bizzi et al., (2003) após a descoberta da província uranífera de Caetité, diversos trabalhos foram realizados com vistas a definir os corpos mineralizados em urânio e suas encaixantes, caracterizar o seu arcabouço estrutural, cronologia e entendimento da gênese da mineralização uranífera e sua distribuição espacial. Com estas características, podem ser citados os trabalhos publicados por Geisel Sobrinho et al., (1980), Raposo \& Matos (1982), Lobato et al., (1983), Brito et al., (1984), Costa et al., (1985), Lobato (1985), Caby \& Arthaud (1987), Maruèjol et al., (1987), Turpin et al., (1988), Lobato \& Fyfe (1990), Maruèjol (1989), Cordani et al., (1992), Pimentel et al., (1994). Recentemente dois trabalhos foram produzidos, Chaves (2013) tece análise propondo novo modelo geológico para os Albititos de Lagoa Real e, 
principalmente, o livro Urânio no Brasil, de autoria do professor Fernando Pires, publicado em 2012, que expõe o "estado da arte", relativo a situação dos depósitos de uranio no Brasil, as perspectivas de cada uma das províncias, distritos e ocorrências.

O maciço de Caetité está localizado na faixa marginal do Cráton São Francisco, a leste da Serra do Espinhaço, tem cerca de $80 \mathrm{~km}$ de comprimento e largura variável entre 30 e $50 \mathrm{~km}$. O embasamento Arqueano/Paleoproterozoico dessa região é formado por rochas granulíticas, migmatíticas e gnáissicas (Complexo Lagoa Real), que pertencem aos blocos Paramirim e Gavião. Estes terrenos são intrudidos por vários corpos graníticos porfiríticos, conhecidos como granito São Timóteo, datados em 1,74 Ga (Turpin et al., 1988; Cordani et al., 1992; Pimentel et al., 1994 e Chaves 2013).

Os gnaisses do Complexo Lagoa Real e o granito São Timóteo são afetados por zonas de cisalhamento regionais, ao longo das quais se localizam uma série de corpos de albititos lenticulares que hospedam as mineralizações uraníferas (Geisel Sobrinho et al., 1980; Brito et al., 1984; Lobato et al., 1982, 1983). Os albititos mineralizados estão distribuídos ao longo de dois alinhamentos principais determinados por cisalhamento, que ocorreram sob influência de fluidos hidrotermais ricos em urânio e sódio (Lobato \& Fyfe, 1990; Chaves 2013). Isso mostra que os processos de cisalhamento, de metassomatismo sódico e de mineralização são contemporâneos (Lobato \& Fyfe, 1990).

Nos depósitos, a uraninita ocorre como principal mineral econômico. Os albititos mineralizados constituem corpos lenticulares (Figura 2.1), localizados ao longo de zonas de cisalhamento. A maioria dos corpos apresenta orientação N40E a N30W e mergulho de $30^{\circ}$ a $90^{\circ}$ para sudoeste ou noroeste, a exceção dos depósitos mais setentrionais, que mergulham para o leste, e aqueles situados na parte central da região, que são quase verticais. Esses corpos de albititos têm comprimento e largura máximos de $3 \mathrm{~km}$ e 30 metros respectivamente e formam "charutos" alongados. A mineralização foi datada em $960 \mathrm{Ma}$, determinada por U-Pb sobre titanita (Pimentel et al., 1994) e provavelmente sofreu recristalização e remobilização em aproximadamente $550 \mathrm{Ma}$, isto é, durante o evento tectono-termal brasiliano (Pimentel et al., 1994 apud Dardenne \& Schobbenhaus, 2001).

Com relação às anomalias uriníferas de Lagoa Real, afloram rochas metamórficasmetassomáticas do embasamento cristalino, com estrutura cataclástica, notadamente granitóides, microclina-plagioclásio augen gnaisses e albititos, parcialmente sob cobertura de sedimentos cenozoicos e solos. 


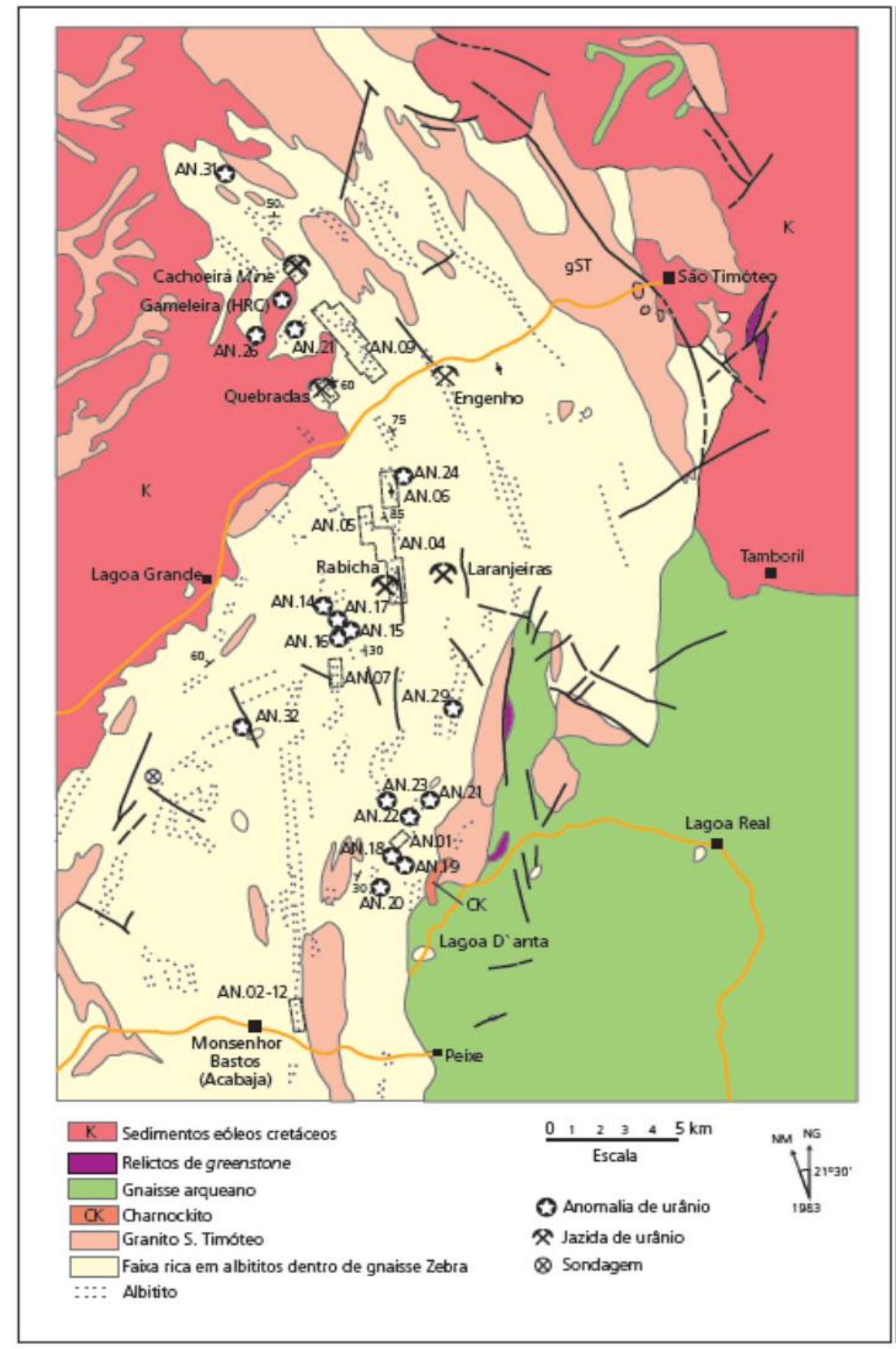

Figura 2.1 - Mapa geológico da Província Uranífera da Lagoa Real que mostra os corpos de albitito, as principais mineralizações e a Mina Cachoeira (Pires 2012, modificado de Maruéjol et al., 1987). 
Do ponto de vista geoquímico, Maruèjol et al., (1987) classificaram os granitoides do Complexo Lagoa Real como intracontinentais, de filiação subalcalina rica em ferro e metaluminosa. Segundo estes autores, a cristalização do magma que originou esses granitos teria ocorrido em condições iniciais de baixa $\mathrm{PH}_{2} \mathrm{O}$ e $f_{2}$, favorecendo a formação do clinopiroxênio e da ilmenita, seguida de um aumento daqueles índices, permitindo o aparecimento da hastingsita e magnetita a partir do piroxênio e da ilmenita, respectivamente.

Teixeira (2000) caracterizou como metaluminoso e calcioalcalino de alto $\mathrm{K}$ o magma que deu origem a esses granitos e postulou que ele teria sido produzido pela fusão parcial de uma crosta ígnea com provável contribuição sedimentar. Contudo, a assinatura geoquímica de alguns elementos traços indicaria que houve, mesmo que com menor importância, a participação de material mantélico alcalino na formação desse magma.

No que se refere à análise cinemática, Hoffmann (1982, apud Brito et al., 1984) propõe que dobras intrafoliais, em bainha, deveriam representar 0 principal controle para 0 acondicionamento da mineralização de urânio nos albititos. Os corpos lenticulares de albititos mineralizados estariam localizados nos flancos de grandes dobras isoclinais, com distribuição preferencial nos locais de intersecção entre duas foliações. Além disso, as lineações minerais observadas nos tectonitos do Complexo Lagoa Real poderiam ser interpretadas como intersecção de duas foliações ou representar eixos de dobras secundárias, localizadas em flancos de dobras isoclinais maiores. Por outro lado, Raposo \& Matos (1982) e Raposo et al., (1984) sugerem que o controle da mineralização de urânio seria dado por falhas regionais.

A gênese dos albititos tem sido atribuída a processos metassomáticos por diversos autores, dentre eles Fyfe (1979, apud Brito et al., 1984), Stein et al., (1980), Brito et al., (1984), Raposo et al., (1984), Lobato (1985), Maruèjol et al., (1987), Maruèjol (1989), Lobato \& Fyfe (1990). De acordo com Stein et al., (1980), Brito et al., (1984), Raposo et al., (1984), Maruèjol et al., (1987) e Maruèjol (1989), o metassomatismo que deu origem aos albititos mineralizados em urânio do Complexo Lagoa Real ocorreu em duas fases principais: (i) metassomatismo sódico, permitindo a substituição do feldspato potássico pelo plagioclásio sódico e neoformação da albita, a formação de piroxênio sódico, a dessilicificação dos minerais; (ii) metassomatismo cálcico, acompanhado de desidratação do anfibólio em piroxênio e granada, neoformação de piroxênio, granada, calcita e fluorita, sendo essas duas últimas tardias. Para Stein et al., (1980), o metassomatismo sódico seria antecedido por um metassomatismo potássico, que teria dado origem aos granitóides alcalinos da região. Lobato (1985) e Lobato \& Fyfe (1990) consideraram a existência apenas do metassomatismo sódico nessas rochas.

Caby \& Arthaud (1987), Maruèjol et al., (1987) e Maruèjol (1989) propõem que os metassomatismos sódico e cálcico estariam associados ao próprio magmatismo anorogênico que deu origem aos granitóides do Complexo Lagoa Real. Para Caby \& Arthaud (1987), esse metassomatismo foi responsável pela formação de um aleitamento primário de albititos enriquecido em urânio. 
De acordo com Stein et al., (1980), o urânio dos albititos Lagoa Real teria sido remobilizado a partir de rochas clásticas dos depósitos vulcanossedimentares de idade arqueana distribuídos no embasamento da região ou a partir de rochas magmáticas colocadas durante o Paleoproterozoico. Posteriormente, Maruèjol et al., (1987) e Maruèjol (1989) concluíram que os minerais ricos em elementos incompatíveis presentes nas rochas encaixantes dos albititos seriam a fonte para o urânio do Complexo Lagoa Real.

Diversos autores reconheceram a associação entre os albititos e as zonas de cisalhamento que deram origem aos gnaisses do Complexo Lagoa Real, tais como Raposo \& Matos (1982), Hoffmann (1982, apud Brito et al., 1984), Costa et al., (1985), Brito et al., (1984), Ribeiro et al., (1984).

Stein et al., (1980), por sua vez, propõem que o metassomatismo que deu origem aos albititos foi anterior à principal fase de deformação registrada nessas rochas. Entre 1,8 e 1,5 Ga, teria havido a formação de bacias sedimentares, acompanhadas de extenso vulcanismo. Os albititos e a mineralização de urânio teriam se formado nessa época, através de processos envolvendo fluidos alcalinos provenientes de granitos tardios ao Evento Transamazônico. A atual distribuição dos corpos de albititos seria o resultado da reconcentração do urânio ao longo de falhas reativadas no Evento Brasiliano.

Sobrinho et al., (1980) sugeriram que as rochas cataclásticas e metassomáticas do complexo foram formadas por processos diapíricos policíclicos. A ascensão de sucessivos de diápiros culminaria com o seu posicionamento epizonal ao iniciar-se o Evento Brasiliano. A reativação diapírica teria propiciado os eventos metassomáticos superpostos aos eventos cataclásticos, afetando as rochas granitizadas do embasamento.

Segundo Chaves (2013), os albititos uraníferos devem ser classificados como sienitos, e não como albititos hidrotermais. Estudos de micropetrografia revelaram textura magmática original, e além disso, as antipertitas demonstraram composição mais sódica do que potássica, dos feldspatos potássicos antes da exsolução. Misturas de texturas magmáticas e metamórficas e frequente textura exclusivamente granoblástica foram geradas durante o cisalhamento. 0 modelo genético proposto para a Província Uranífera de Lagoa Real associa urânio a processos cíclicos de diapirismo, entretanto, difere dos demais quando geocronologicamente aponta o magmatismo como Orosiriano.

De acordo com Pires (2012) os albititos hidrotermais foram formados durante o metamorfismo em fácies anfibolito, ao longo de zonas de cisalhamento, em vários estágios de alteração metassomática:

- albitização precoce de feldspatos, com total eliminação do quartzo;

- transformação da hornblenda em piroxênio;

- formação de andradita a partir da aegirina-augita;

- substituição da magnetita por hematita;

- alteração final, incluindo hornblenda, biotita, carbonatos e prehnita, sendo o protolito 
representado pelo ortognaisse regional (Lobato \& Fyfe, 1990, apud Pires, 2012).

Fyfe propôs que imensa falha de empurrão thin-skinned thrust tenha produzido inversão termal com consequente retrometamorfismo e metassomatismo (no bloco superior), e metamorfismo progressivo (no bloco inferior) sob ação de fluidos meteóricos, pois os valores isotópicos de oxigênio $(\delta 18 \mathrm{OH} 2 \mathrm{O}=-3,7 \%$ a $+2,6 \%$ sMOW nos albititos mineralizados e $\delta 18 \mathrm{OH} 2 \mathrm{O}=-0,8 \%$ o $+7,3 \%$ SMOW nos albititos não mineralizados) contrariam a hipótese de circulação de fluidos magmáticos ou metamórficos (Lobato \& Fyfe, 1990, apud Pires, 2012).

Ainda, de acordo com Pires (2012), aparentemente a uraninita concentra-se principalmente nas fases máficas (piroxênio, granada, allanita e anfibólio) e na interface albitaminerais máficos, em temperaturas decrescentes, em que ocorrem reações de desidratação e metassomatismo de $\mathrm{CO}_{2}$.

O metassomatismo de $\mathrm{CO}_{2}$ contribuiu para formar mineralizações uraníferas em mecanismo ainda pouco compreendido, assim como a dissolução da sílica e a expulsão do K do sistema, se é que eles existiram no protolito. Outro ponto importante é que o biotita gnaisse (que recebeu a denominação durante as atividades de campo de gnaisse tipo "zebra") encaixante da mineralização se torna avermelhado e magnético, devido ao conteúdo de magnetita (e hematita não reequilibrada), podendo-se concluir aumento da fugacidade de oxigênio para as encaixantes e consequente diminuição de oxigênio para a zona mineralizada. Ressalta-se ainda que foram descritos albititos não mineralizados (ou estéreis), mas não foi explicada a razão de serem estéreis. Provavelmente estes albititos não tenham sido submetidos à deformação máxima, permitindo a entrada de fluídos uraníferos sob alta pressão.

Segundo Chaves (2013) os sedimentos aluviais terciários e quaternários complementam a configuração geológica da região.

\subsection{Geologia Local}

A área onde se desenvolve este trabalho foi alvo de várias atividades de campo, ao longo dos últimos seis anos. Com isso pode-se acompanhar as alterações que o meio sofreu nesse período. Em 2008 existiam duas cavas em operação, alcançando profundidade máxima de 90 metros. Nos anos seguintes houve exploração subterrânea - finalizada atualmente, abertura de mais uma cava e a profundidade alcançada no ano de 2014 foi de 150 metros.

No contexto dos locais visitados (Figura 2.2,), que inclui além dos domínios do Complexo Mínero-industrial a região de Maniaçú, São Timóteo, Lagoa Real, afloram rochas do Granito São Timóteo (Figura 2.3) e Gnaisses do Complexo Lagoa Real (Figura 2.4). 


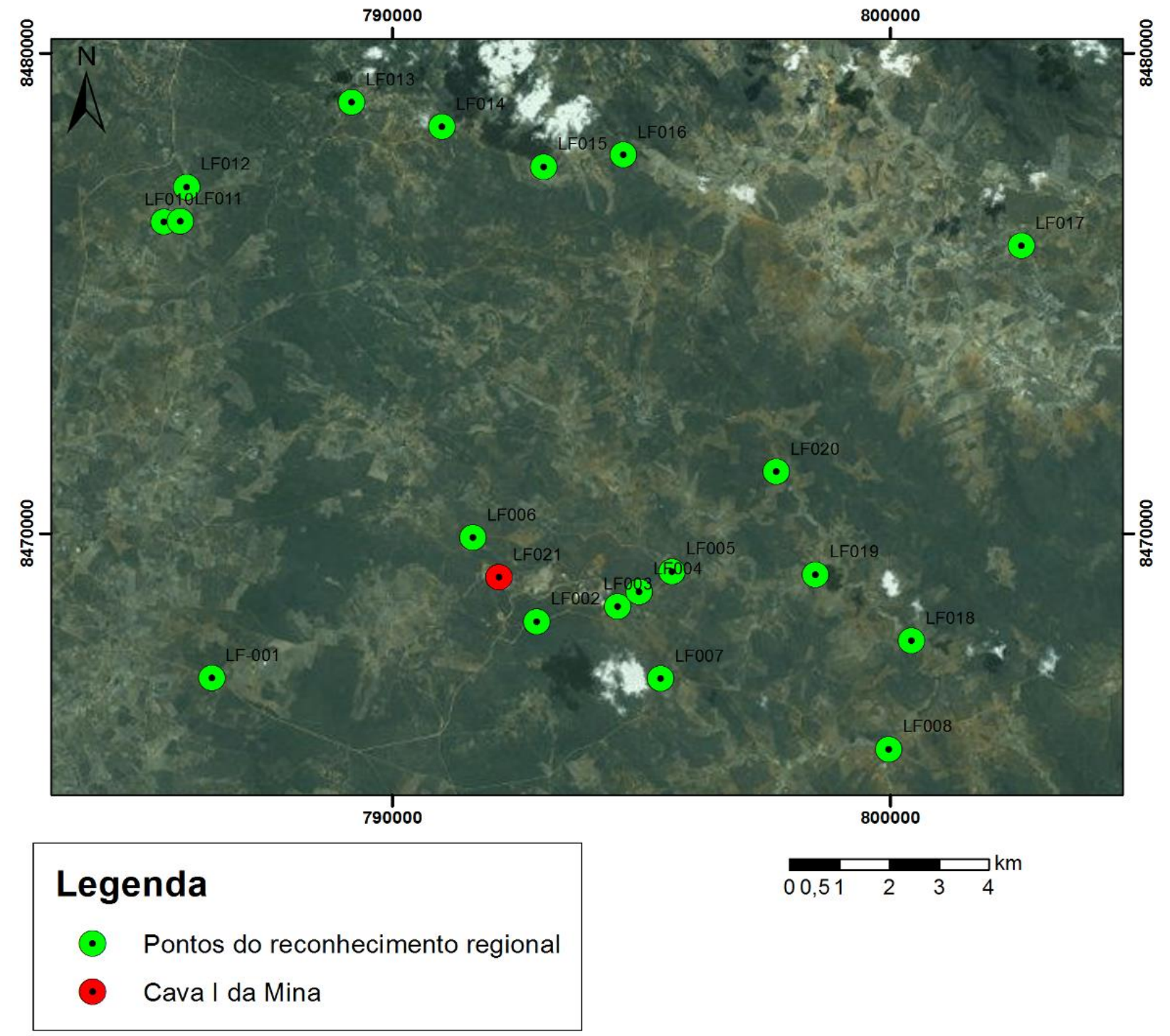

Figura 2.2 - Localização dos pontos visitados na atividade de campo realizada em março de 2014.

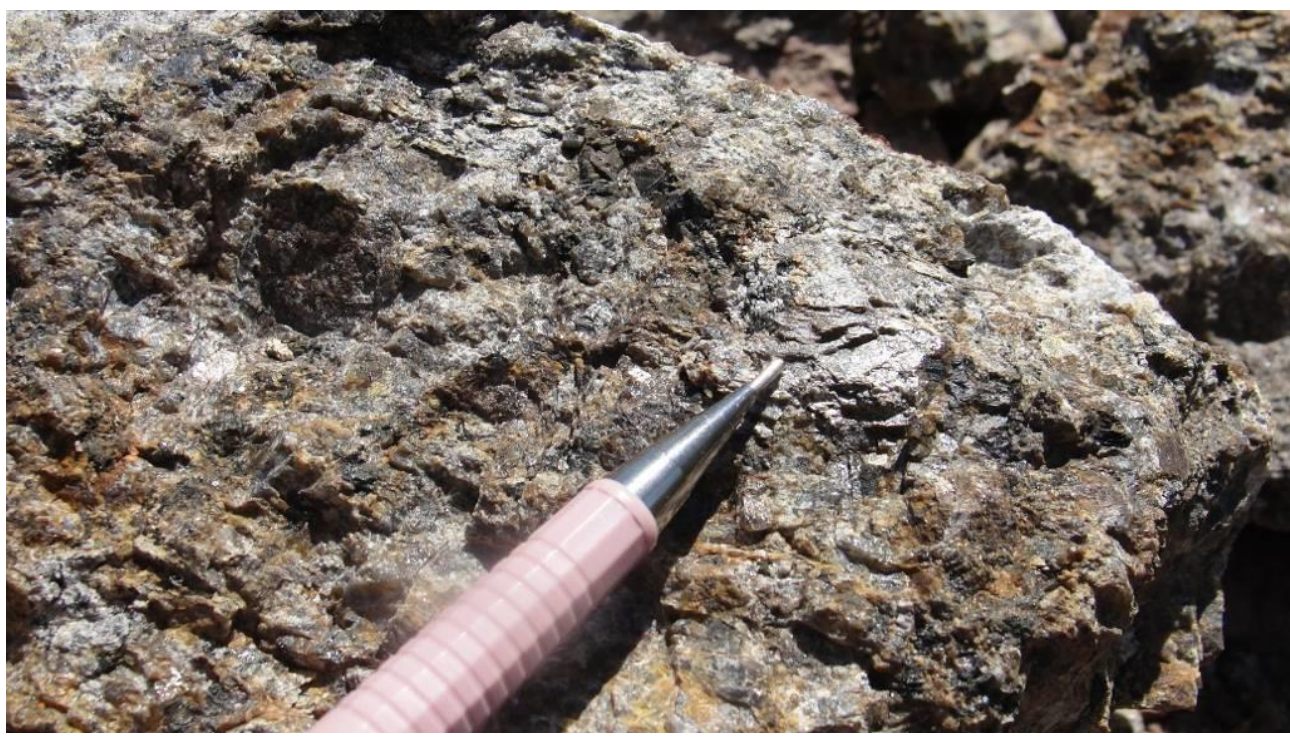

Figura 2.3 - Granito São Timóteo (fotografia registrada em março de 2014, durante visita a área). 


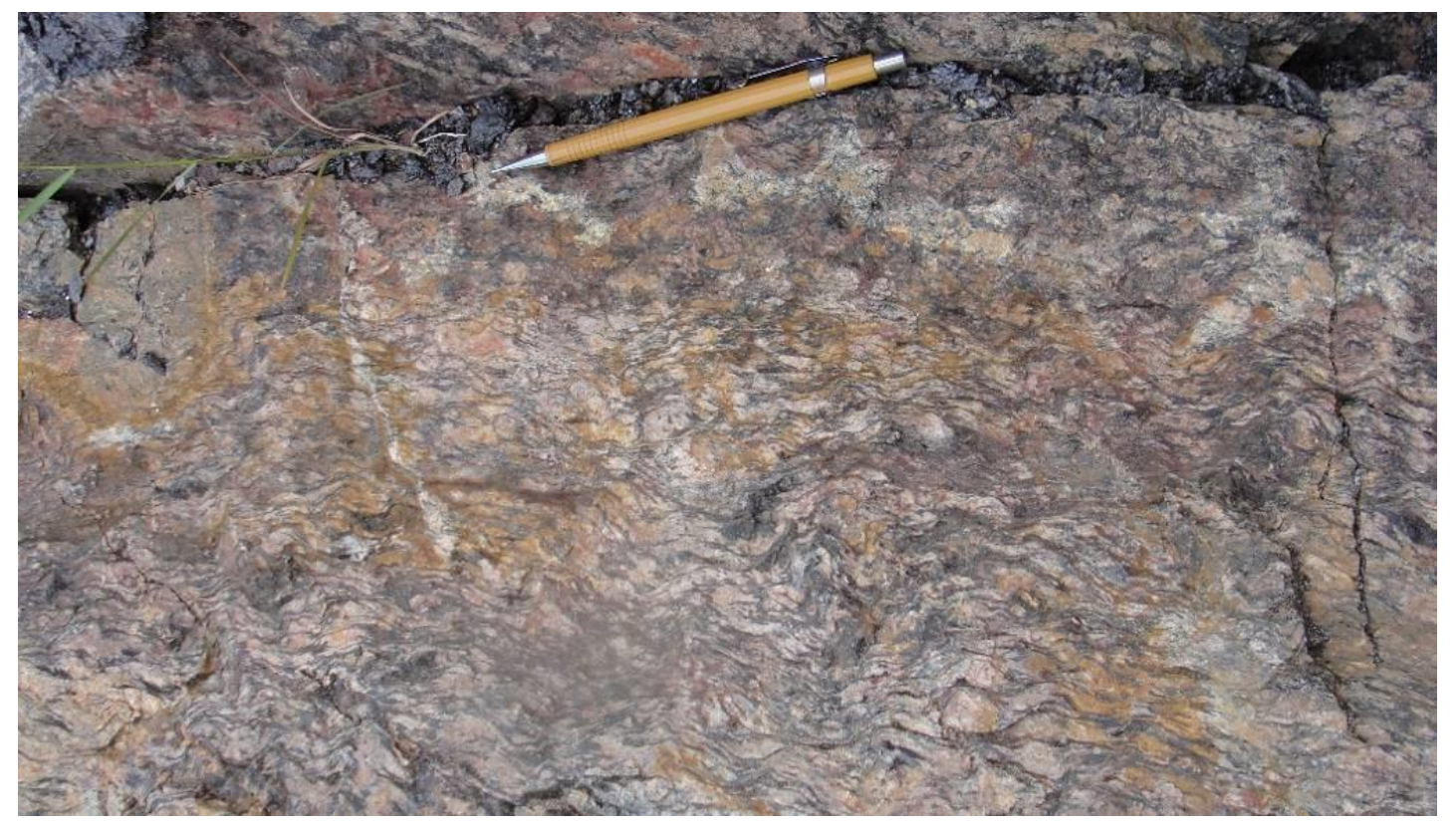

Figura 2.4 - Gnaisse do Complexo Lagoa Real (fotografia registrada em março de 2014, durante trabalho de campo).

O Granito São Timóteo caracteriza-se pela coloração cinza média a cinza rosada, de granulação grossa, isotrópica e textura pegmatóide. Os principais minerais são a microclína pertítica, quartzo, plagioclásio, biotita e anfibólio. Possui composição granítica, quartzomonzonítica ou quartzo-sienítica. Nos afloramentos visitados, observou-se um biotita granito grosso a muito grosso, porfirítico e isotrópico, cor cinza claro, com quartzo azul. Ainda apresentava cristais de k-feldspato com cerca de 1-2 cm, alguns zonados, com inclusões de biotita. Outro aspecto comum é o caráter magnético da rocha.

De acordo com Geocervices (2004), os gnaisses do Complexo Lagoa Real na área de estudo foram subdivididos nos seguintes tipos litológicos: augen-gnaisses, plagioclásio-augengnaisses, quartzo-plagioclásio-microclínio-gnaisse ondulado, microclínio-gnaisse fitado, quartzoplagioclásio-gnaisse fitado e albititos.

Augen-gnaisses - correspondem aos gnaisses quartzo-feldspáticos, de coloração cinza rosada a cinza média, granulação média a muito grossa e foliação gnáissica irregular. Os fenoclastos de microclínio ou de oligoclásio, de formato tabular ou arredondado (de até $10 \mathrm{~cm}$ de comprimento) ocorrem em meio a uma matriz composta de quartzo, plagioclásio e máficos.

Plagioclásio Augen-gnaisse - estes se diferenciam dos augen-gnaisses pela dominância do plagioclásio em relação ao microclínio.

Quartzo-Plagioclásio-Microclínio gnaisse ondulado - composicionalmente aproximam-se dos gnaisses fitados e dos augen-gnaisses, correspondendo à transição entre estes dois tipos. Os principais minerais formadores são o microclínio, albita-oligoclásio, quartzo, biotita e/ou anfibólio, ocorrendo a segregação dos minerais máficos e félsicos em bandas máficas e félsicas, de espessura milimétrica.

Microclínio-gnaisses Fitados - correspondem a rochas de coloração rosada ou 
esbranquiçada, granulação fina a média, finamente fitado, com segregação de minerais, separando o quartzo, anfibólio e biotita e dos agregados sacaroidais de feldspato branco e rosado. As faixas segregadas ocorrem regularmente na rocha, possuindo espessura média de 1 $\mathrm{cm}$. As faixas de minerais félsicos podem atingir, ocasionalmente, até $50 \mathrm{~cm}$ de espessura Geocervices (2004).

Durante as atividades de campo foram constatadas nos gnaisses variações texturais e composicionais, além de exibir forte controle estrutural (foliação regional) de direção NW-SE. As medidas de xistosidade (Sx) são de aproximadamente $020 \% 55^{\circ}$ (dip/dip), podendo haver variações locais tais como: $055^{\circ} / 65^{\circ}, 090^{\circ} / 70^{\circ}, 070^{\circ} / 68^{\circ}$ (dip/dip). Todo o conjunto de rochas está fortemente fraturado, com fraturas que vão de subverticais a sub-horizontais (Figura 2.5). As fraturas sub-horizontais recortam as demais estruturas e chegam a profundidades de 150 metros, o que é confirmado com observações nas cavas das minas e nas descrições dos furos de sondagem fornecidos pela INB.

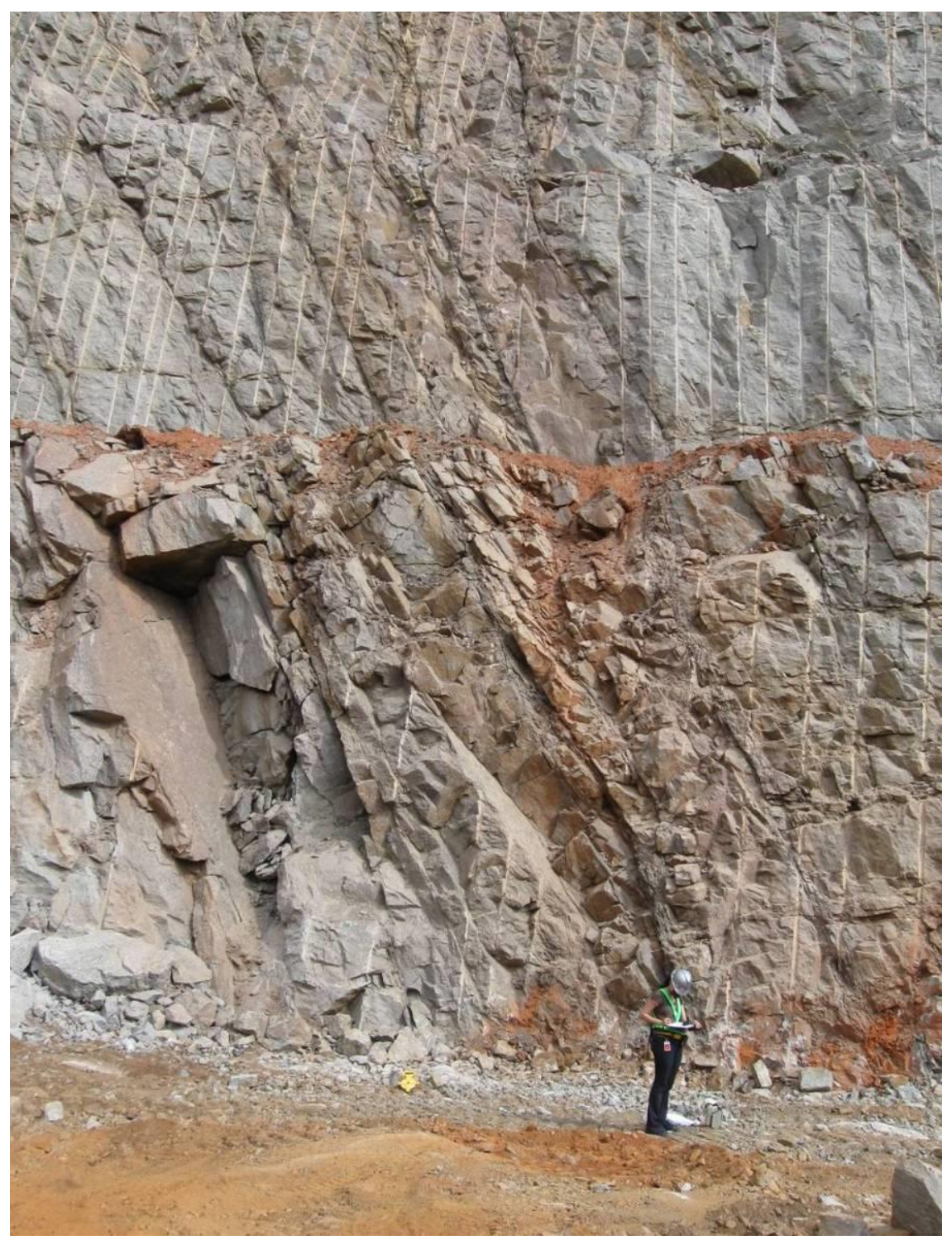

Figura 2.5 - Foto cava da mina, Corpo III, planos de falha e fraturas sub-horizontais. 
Há também expressiva zona de cisalhamento na área de estudo, especialmente nítida nos afloramentos, resultantes da extração mineral. Essas zonas cisalhadas apresentam alternância de faixas com graus de cisalhamento distintos. As bandas pouco cisalhadas caracterizam-se pela ocorrência de gnaisses com variação textural, desde protomilonitos até milonitos e ultramilonitos. As zonas onde o cisalhamento é mais forte definem-se por apresentar estruturas sigmoides, orientação preferencial de $080^{\circ} / 80^{\circ}$ e formação de bandas de biotitito (Figura 2.6).

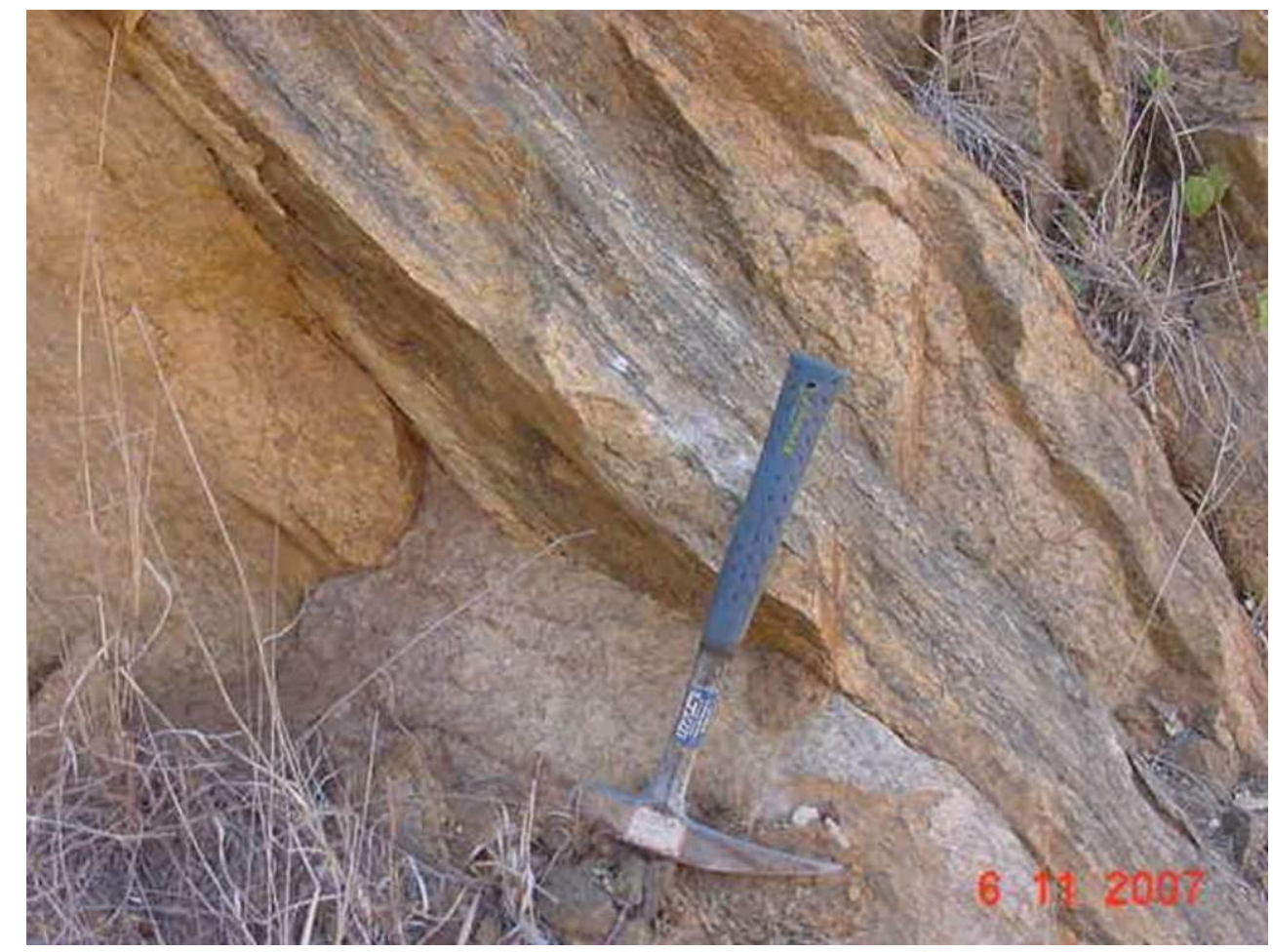

Figura 2.6 - Foto de banda enriquecida em biotitita em zona de cisalhamento, compondo rocha caracterizada como biotitito.

O Gnaisse "Zebra", notadamente um Quartzo Biotita gnaisse, foi assim denominado por apresentar lentes de Biotita (Figura 2.7). Este é bastante comum em toda a área do empreendimento minerário. Apresenta Sx $020 \% 65^{\circ}$ e lineação down dip. A associação mineral é formada por plagioclásio (albita) pertítica, quartzo, microclínio, biotita, hornblenda, titanita, carbonato, minerais opacos, zircão e apatita. Os minerais opacos apresentam-se envoltos por titanita e algumas vezes por carbonato encontrando-se também neles fission tracks, estruturas causadas por radioatividade. Ainda ressalta-se que, em alguns locais, este gnaisse expõe finas intercalações de Biotita e bandas miloníticas. Nessas rochas pode-se observar, nos níveis mais cisalhados, bolsões de carbonato com epidoto, martita, siderita, granada e sulfetos associados.

Microclínio Albita gnaisse, mais félsico com assembleia mineral composta por microclínio, quartzo, epidoto, titanita, plagioclásio e minerais opacos.

Biotita Albitito gnaisse, em que as lamelas de biotita encontram-se orientadas segundo Sx da rocha e há foliação anastomosada. A paragênese mineralógica é composta por pertita, plagioclásio, microclínio, quartzo, carbonato e minerais opacos. 


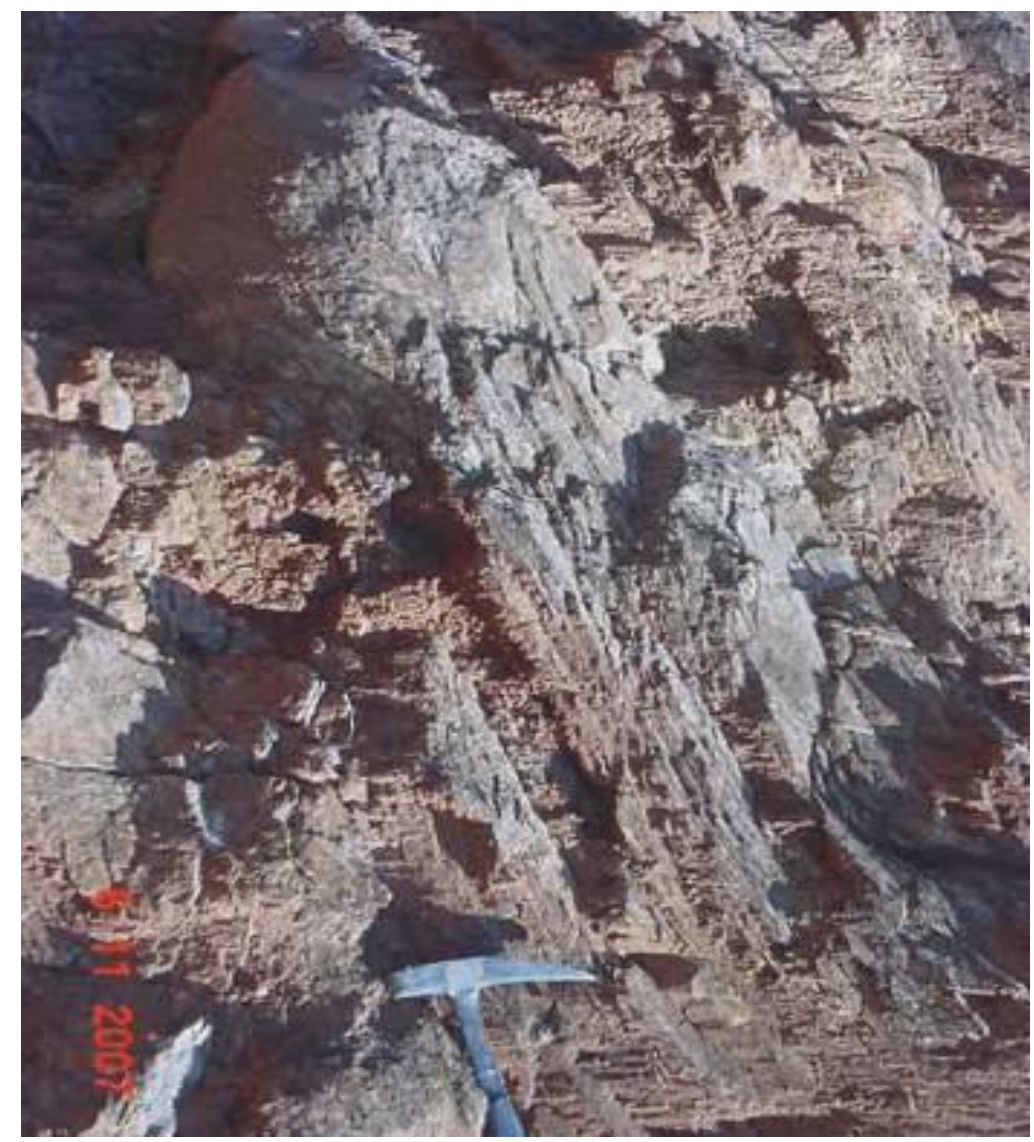

Figura 2.7 - Gnaisse Zebra, exposto no canal de desvio das águas de drenagem da cava das minas.

As estruturas observadas na área são a foliação tectono-metamórfica (gnáissica), os sistemas de falhas e fraturas que variam desde subverticais até sub-horizontais e as zonas de cisalhamento. Com exceção das cavas da Mina Cachoeira, os afloramentos são pouco expressivos na área. As fraturas sub-horizontais encontram-se até a profundidade de 150 metros, de acordo com o observado nos afloramentos, resultantes da exposição de rocha pela atividade de mineração. Essas estruturas têm sua gênese relacionada, tanto ao alívio de tensões do maciço rochoso, quanto a falhas de empurrão de baixo ângulo, como será apresentado no capítulo 3.

De acordo com Pires (2012) o mapeamento detalhado da Mina Cachoeira e arredores possibilitou a identificação de padrão de dobramento fechado em sequência de sinformais e antiformais (Figuras 2.8, 2.9 e 2.10, Anexos 01 e 02), zona de cisalhamento com elevadíssimo strain, qualitativamente, controlando a mineralização uranífera, bordejada por gnaisses e biotititos em zona de cisalhamento com menor strain e, na parte mais externa, faixas delgadas com epidositos (Figura 2.11). 


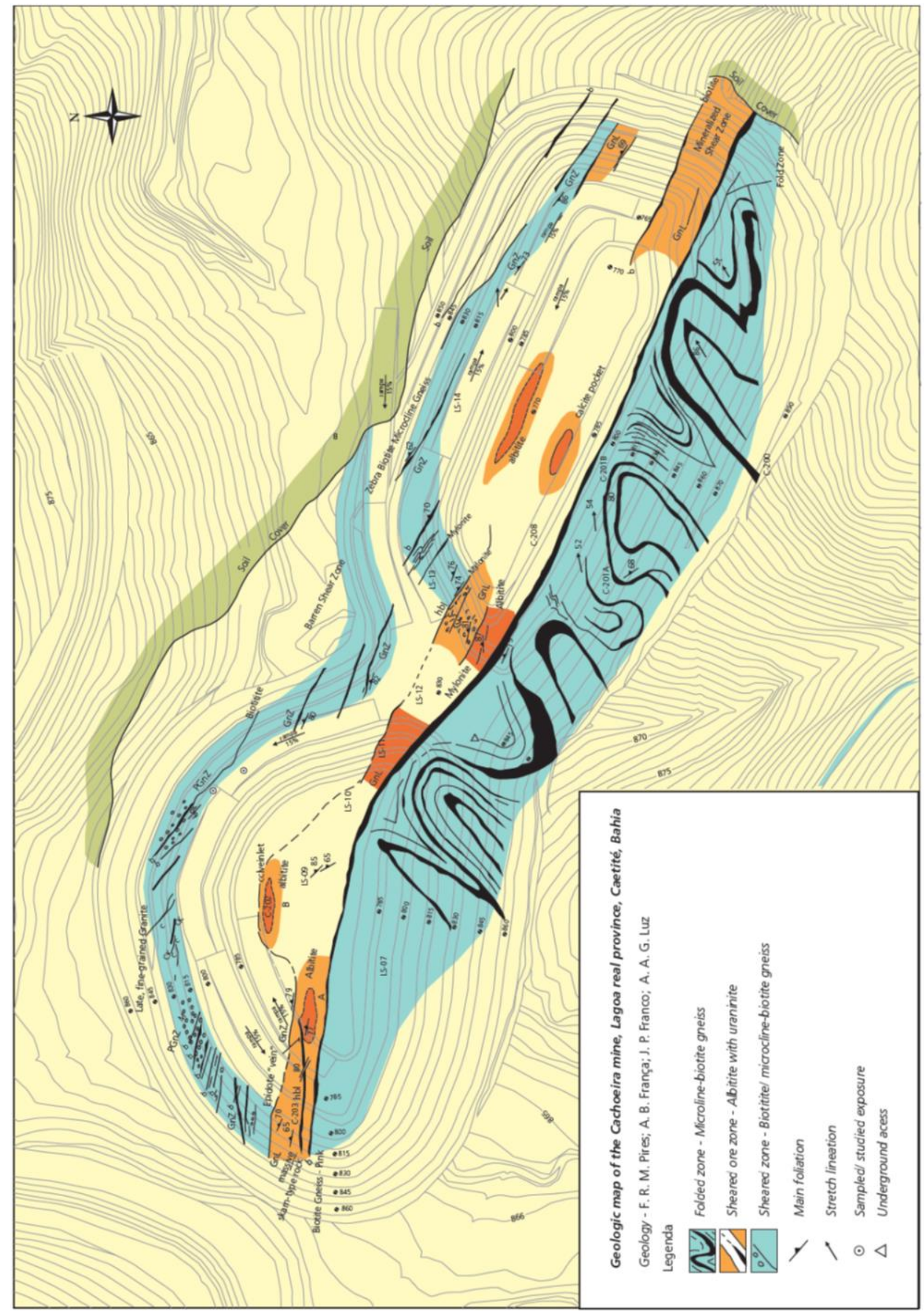

Figura 2.8 - Mapa Geológico da mina Cachoeira, corpo I e II de baixo para cima da imagem (Pires, 2012). 


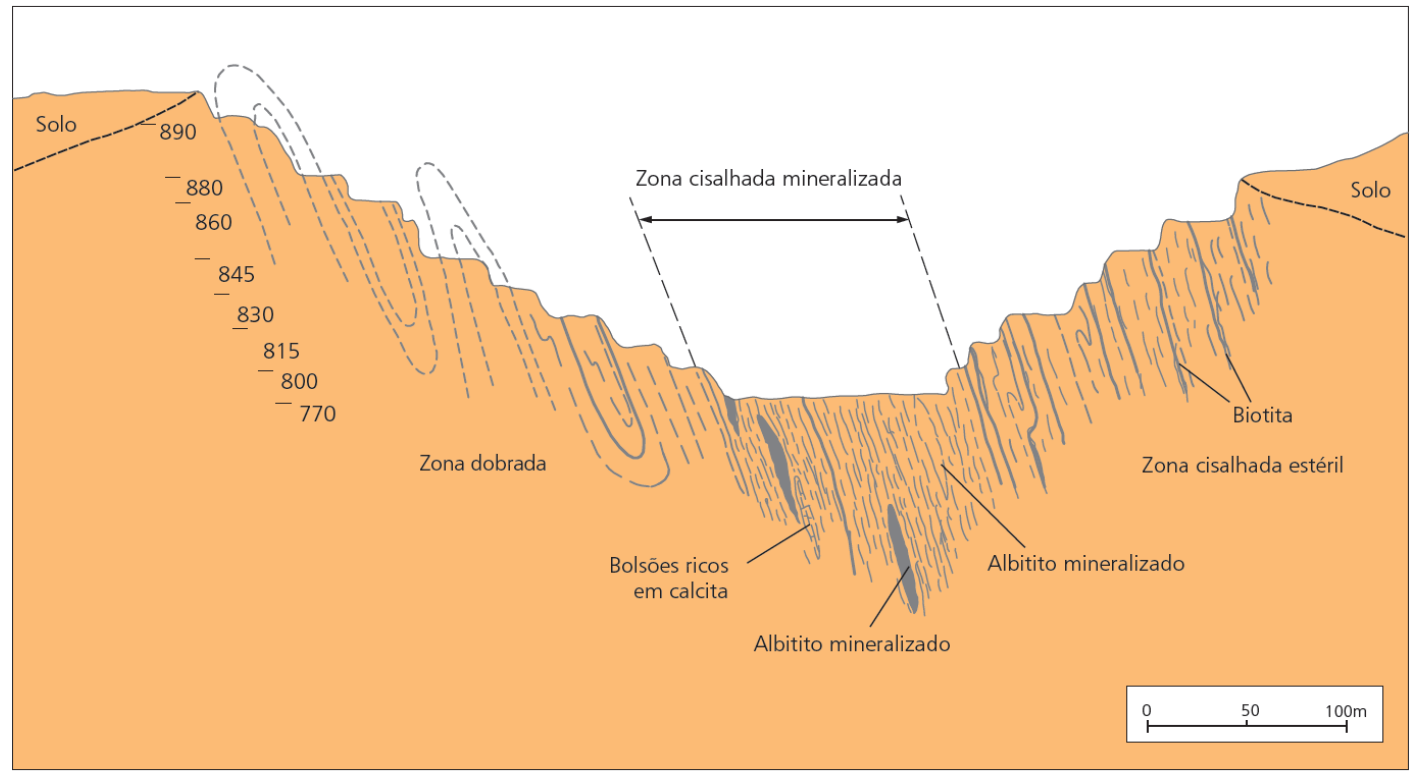

Figura 2.9 - Seção geológica da Mina Cachoeira, Caetité, Bahia (Pires et al., 2010, apud Pires, 2012).

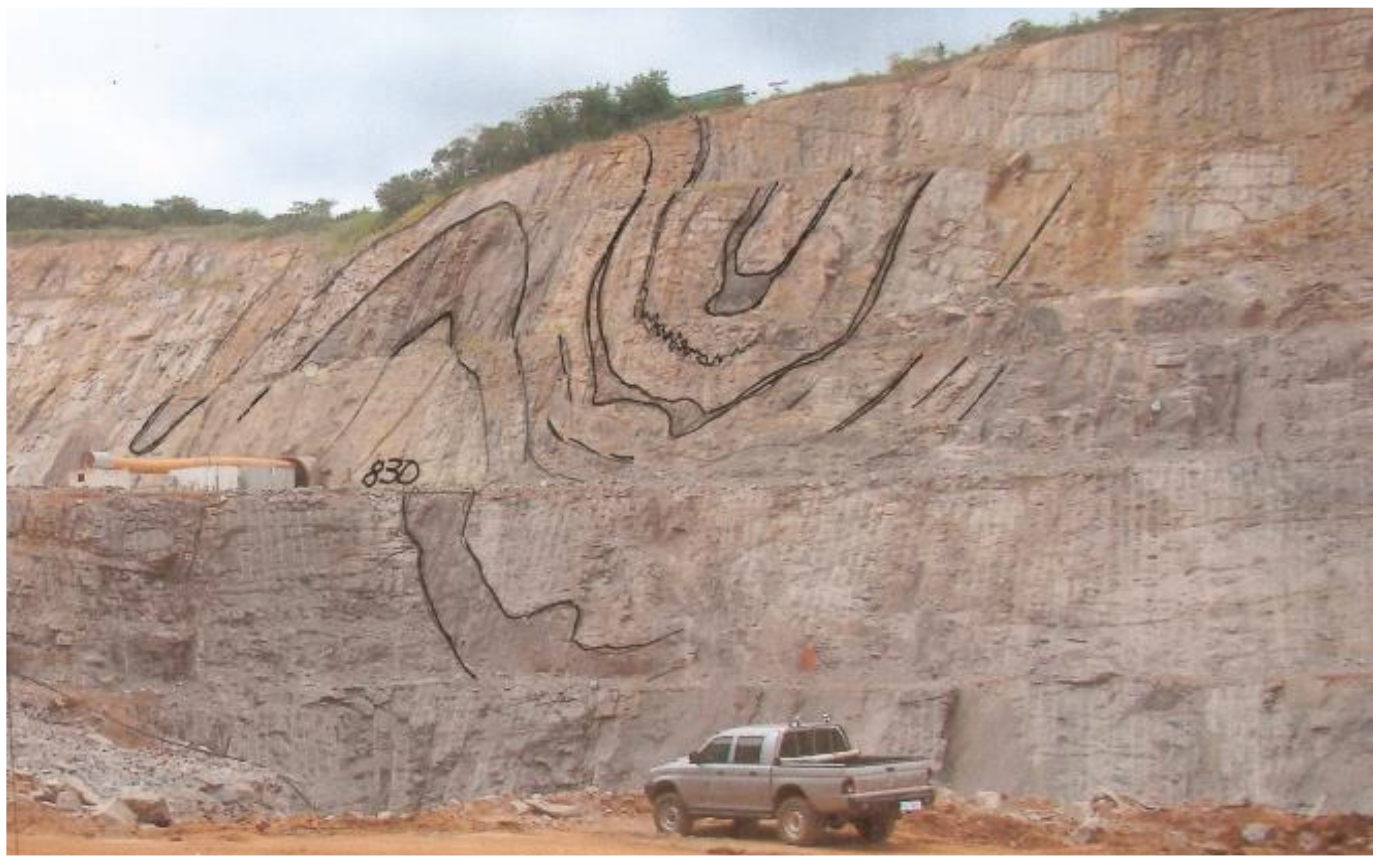

Figura 2.10 - Dobras meso a megascópicas, Mina Cachoeira (foto: Jamyle Praxedes apud Pires, 2012).

Ainda, de acordo com Pires (2012), observou-se no mapeamento da cava da mina que os eixos das dobras são paralelos ao cisalhamento e variam de mergulhos verticais a suaves, em frequentes gradações, a dobras normais a reclinadas. Aparentemente, os corpos mineralizados paralelos foram repetidos pelo dobramento, mas em zonas fortemente cisalhadas e boudinadas, os corpos tomam a forma prolata ("charutos"), gradando à forma oblata ("panquecas"), obrigando ao planejamento cuidadoso de sondagens e de lavra. Aparentemente, as zonas sigmoides desaparecem nas zonas de maior deformação, apagadas pela milonitização e subsequente forte recristalização. 


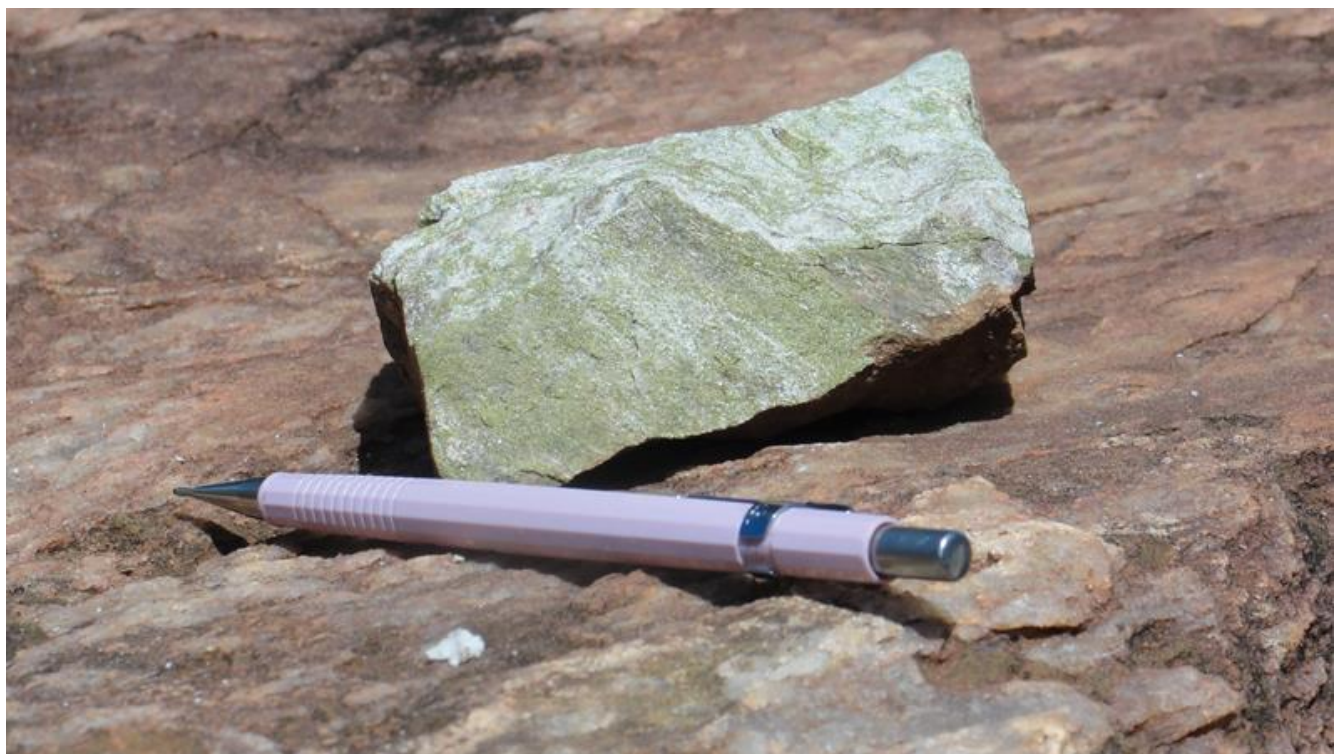

Figura 2.11 - Epidositos junto a área do Complexo mínero-industrial, observados durante atividade de campo em março de 2014.

\subsection{Uraninita}

O urânio é o último elemento químico natural da tabela periódica. É o átomo com o núcleo mais pesado que existe naturalmente no planeta que contém em seu núcleo 92 prótons e, de 135 a até 148 nêutrons. Faz parte do grupo de elementos naturais radioativos.

Esse elemento pode ser encontrado em quase todos os tipos de rochas crustais. Pela ação do intemperismo de rochas contendo seus isótopos, o urânio se oxida facilmente de $\mathrm{U}^{+4}$ a $\mathrm{U}^{+6}$, sendo lixiviado facilmente, migrando em forma de complexos orgânicos, principalmente sob a ação do $\mathrm{CO}_{2}$ do ar ou presente na rocha hospedeira (Scislewski, 2004). Também é transformado em produtos de alteração intempérica. O mineral de urânio mais comum é a uraninita. Minerais resultantes de alteração intempérica mais comuns são uranofana e autunita.

Em Webmineral (2009), site da Sociedade Americana de Mineralogistas, são apresentadas as definições de mineral adotadas pela comunidade científica ao longo do tempo:

$\checkmark$ "A mineral is an element or chemical compound that is normally crystalline and that has been formed as a result of geological processes" (Nickel, 1995, apud Webmineral, 2009).

$\checkmark$ "Minerals are naturally-occurring inorganic substances with a definite and predictable chemical composition and physical properties" (O' Donoghue, 1990, apud Webmineral, 2009).

$\checkmark$ "A mineral is a naturally occurring homogeneous solid, inorganically formed, with a definite chemical composition and an ordered atomic arrangement" (Mason, et al., 1968, apud Webmineral, 2009).

$\checkmark \quad$ "These... minerals ...can be distinguished from one another by individual characteristics that arise directly from the kinds of atoms they contain and the arrangements these atoms make inside them" (Sinkankas, 1966, apud Webmineral, 2009).

$\checkmark$ "A mineral is a body produced by the processes of inorganic nature, having usually a 
definite chemical composition and, if formed under favorable conditions, a certain characteristic atomic structure which is expressed in its crystalline form and other physical properties" (Dana \& Ford, 1932, apud Webmineral, 2009).

$\checkmark$ "Every distinct chemical compound occurring in inorganic nature, having a definite molecular structure or system of crystallization and well-defined physical properties, constitutes a mineral species" (Brush \& Penfield, 1898, apud Webmineral, 2009).).

Adota-se aqui a definição de mineral como "substância sólida, normalmente inorgânica, de ocorrência natural, homogênea e com composição química e estrutura cristalina constantes e definidas". Os minerais podem ocorrer como cristais ou amorfos. Os primeiros são corpos com forma geométrica limitada por faces arranjadas de maneira regular, relacionadas com a orientação da estrutura interna. Os amorfos não têm estrutura cristalina definida, mas a composição química é constante e a estrutura é amorfa (Silva, 2009).

As propriedades físicas dos minerais resultam diretamente de sua composição química e de suas características estruturais, que são geneticamente produzidas pelas condições de pressão, temperatura e disponibilidade química no momento da formação desse mineral.

Segundo Heinrich (1966), a uraninita (Figuras 2.12 e 2.13) é o principal mineral-minério de urânio. Trata-se de um óxido de urânio, marrom-aveludado, preto, cinza aço ou verde-escuro. Forma cubos ou octaedros com brilho de piche. Pode conter tório, rádio, cério, e metais do grupo do ítrio. Forma série isomórfica com a torianita $\left(\mathrm{ThO}_{2}\right)$. Segundo Branco (1979) ocorre em veios de chumbo, estanho e cobre, em arenitos, granitos e pegmatitos. Mesmo sendo o principal, existem outros minerais contendo urânio na sua composição química além da uraninita.

A composição ideal da uraninita é $\mathrm{UO}_{2}, \mathrm{com} U=46,5$ a 88,2 \%, mas não existe nenhuma substância natural que seja exatamente $\mathrm{UO}_{2}$. Normalmente, o $U^{4+}$ se oxida a $U^{6+}$. Como o $U^{6+}$ é um íon menor, o oxigênio penetra e ocupa posições intersticiais. A uraninita se converte a $\mathrm{U}_{3} \mathrm{O}_{8}$ quando aquecida ao ar durante cinco minutos.

$\mathrm{Na}$ Tabela 2.1 são comparadas as propriedades mineralógicas da uraninita e da torianita. Em muitas uraninitas pegmatíticas, a relação $\mathrm{UO}_{2} / \mathrm{UO}_{3}$ é elevada, sendo esta, também, uma característica da uraninita metassomática de contato, mas, normalmente, a razão é pequena em uraninitas não pegmatíticas. 


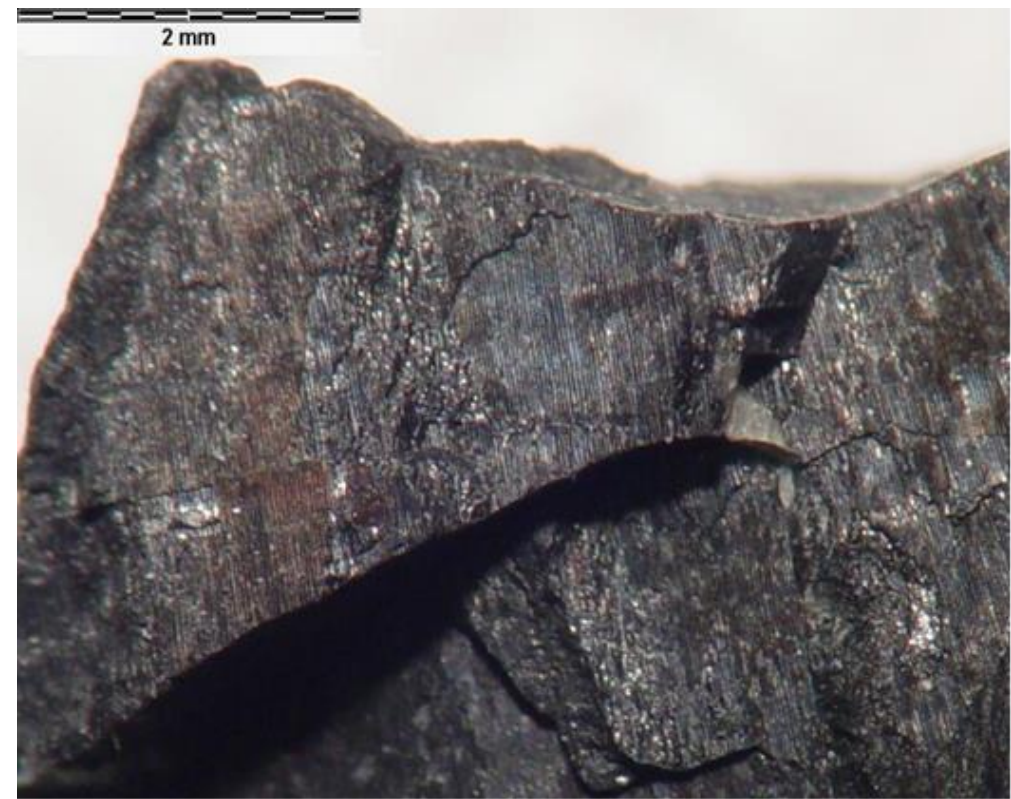

Figura 2.12 - Uraninita (Webmineral, 2009, apud Silva, 2009).

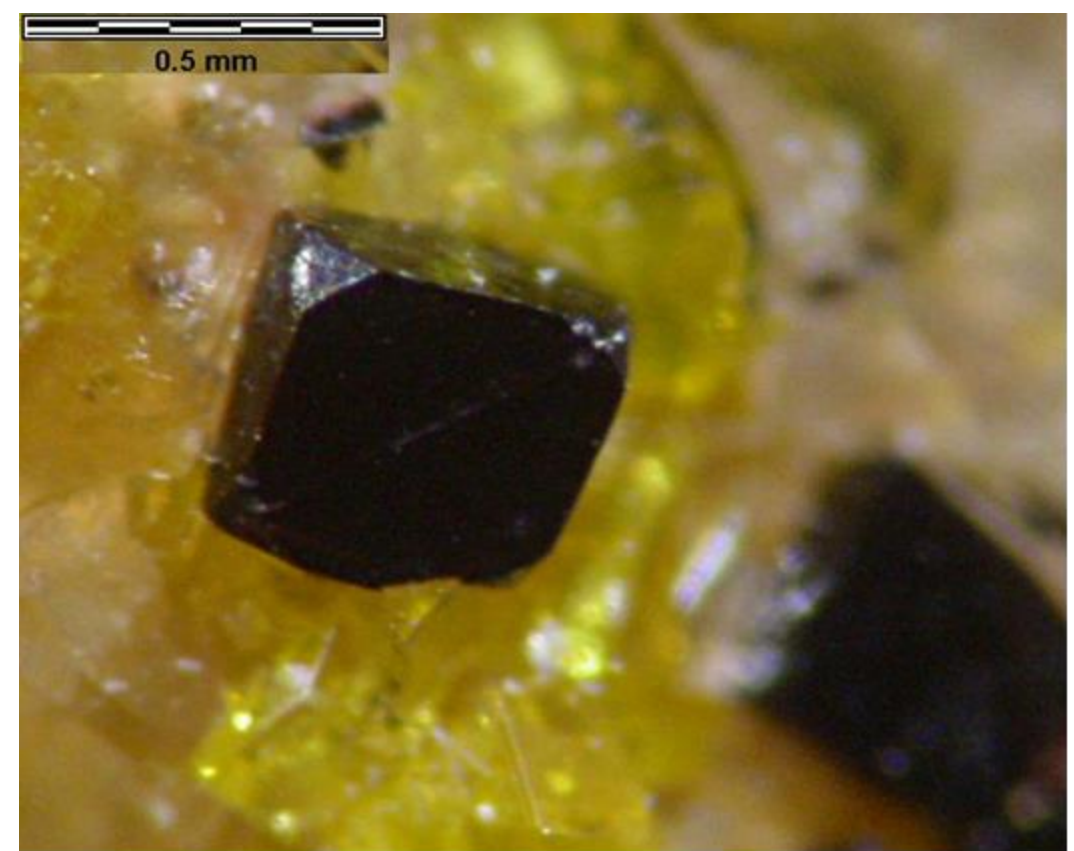

Figura 2.13 - Uraninita (Webmineral, 2009, apud Silva, 2009).

\begin{tabular}{|c|c|c|c|c|c|}
\hline Mineral & Forma & Cor, traço & $\begin{array}{c}\text { Clivagem e } \\
\text { fratura }\end{array}$ & Densidade & $\begin{array}{c}\text { Peso } \\
\text { específico }\end{array}$ \\
\hline Uraninita & $\begin{array}{l}\text { Isométrica, cubos, } \\
\text { octaedros; são } \\
\text { comuns as faces } \\
\text { octaédricas nos } \\
\text { tipos com baixo } \\
\text { conteúdo em Th. } \\
\text { Não metamítica. }\end{array}$ & $\begin{array}{l}\text { De negro a } \\
\text { cinza escuro. } \\
\text { Brilho } \\
\text { submetálico a } \\
\text { resinoso; } \\
\text { Traço: de negro } \\
\text { a verde oliva } \\
\text { escuro }\end{array}$ & $\begin{array}{l}\text { Fraturas } \\
\text { irregulares a } \\
\text { conchoidais }\end{array}$ & $\begin{array}{l}\text { 5-6,5 que diminui } \\
\text { quando aumenta o } \\
\text { conteúdo de } U^{6} \text {. Os } \\
\text { tipos fuliginosos têm } \\
\text { agregados com } \\
\text { densidade e peso } \\
\text { específico muito mais } \\
\text { baixos. }\end{array}$ & $8,0-10,5$ \\
\hline Torianita & $\begin{array}{l}\text { Isométrica, cubos. } \\
\text { Maclas comuns } \\
\text { segundo (111). } \\
\text { Não metamítica. }\end{array}$ & $\begin{array}{l}\text { Cinza a negro. } \\
\text { Traço: verde a } \\
\text { cinza. Brilho } \\
\text { submetálico a } \\
\text { gorduroso. }\end{array}$ & $\begin{array}{l}\text { (001) } \\
\text { Poucas }\end{array}$ & $5-7$ & $9,2-9,7$ \\
\hline
\end{tabular}

Tabela 2.1 - Dados de comparação entre uraninita e torianita (Heinrich,1966, apud Silva, 2009). 
É possível que parte do $\bigcup_{6}$ seja primário e que a quantidade inicial de $U^{6+}$ dependa da temperatura de formação da uraninita, que ao ser produzida em temperaturas mais baixas, tenha quantidades maiores desse $U^{6+}$ Wasserstein (1954) apud Heinrich 1966 (op. cit.) classificou a uraninita em três classes:

1) a-uraninita: $\mathrm{U}_{4} \mathrm{O}_{7}$ (deficiente em oxigênio);

2) $\beta$-uraninita: $\mathrm{U}_{2} \mathrm{O}_{4}$ (uraninita strictu sensu); e

3) Y-uraninita: $\mathrm{U}_{3} \mathrm{O}_{7}$ (oxigênio em excesso, pechblenda strictu sensu).

Importante substituto do $U$ é o Th, e existe uma série contínua entre a uraninita e a torianita, mas a divisão entre as duas espécies se define pela razão $U: T h=1: 1$. O conteúdo de Th na uraninita chega a 45,3\%. As uraninitas de filões hidrotermais podem conter menos de $0,25 \%$ de $\mathrm{ThO}_{2}$, mas as uraninitas pegmatíticas, normalmente, têm acima de $2 \%$ (Silva, 2009).

A uraninita se altera facilmente em numerosos óxidos secundários hidratos, carbonatos, sulfatos, fosfatos, arseniatos, vanadatos e silicatos de $U$ e outros elementos. Também pode ser substituída por tucolita (mistura de hidrocarbonetos com uraninita e sulfetos), em alguns casos, pseudomorficamente, e por vários sulfetos, sobre tudo a calcopirita (sulfeto de cobre e ferro$\mathrm{CuFeS}_{2}$ ). Os cristais de uraninita podem apresentar zonas de alteração muito bem definidas devido à lixiviação seletiva de alguns elementos (Silva, 2009). O Th é lixiviado com maior facilidade do que o $U^{4}$. O Pb migra mais facilmente que o $U^{4+}$, mas depois da conversão $U^{4}$ em $\mathrm{U}^{6+}$, o $\mathrm{U}^{6+}$ se perde muito mais rapidamente que o Th e o $\mathrm{Pb}$ (Ellsworth, 1932 apud Heinrich, op.cit.). A uraninita é facililmente alterada por intemperismo, soluções hidrotermais, soluções meteóricas e auto-oxidação.

Heinrich (op.cit) descreve que a uraninita apresenta as seguintes formas de ocorrências / paragêneses:

1) em pegmatitos graníticos se associa com zircão (silicato de zircônio- $\mathrm{ZrSiO}_{4}$ ), monazita (silicato de cério, lantânio, neodímio e tório), quartzo fumê, feldspato vermelho, berilo, turmalina, muscovita, biotita, granada, apatita e, também, com a tucolita. Menos frequentemente, com óxidos complexos radioativos que contêm Ta e $\mathrm{Nb}$, como a columbita-tantalita (COLTAN), betafita (tântalo-niobato de cálcio, sódio e urânio) e fergusonita (tântatlo-niobato de ítrio). Há vários exemplos pelo mundo, já no Brasil, pode-se citar Brejeúba e Engenho Central, em Minas Gerais, Picuí, na Paraíba e Parelhas, Acari e Currais Novos, no RN;

2) em pegmatitos sieníticos com núcleo de calcita-fluorita-apatita, encontrado em Wilberforce, Ontário;

3) raramente em jazimentos pirometassomáticos: no contato alterado de mármores e metapiroxenitos, em serpentinitos e em piroxenitos;

4) em filões hidrotermais de altas temperaturas: com hematitas, com arsenetos de Co-Ni e molibdenitos; e

5) em alguns tipos de filões hidrotermais de baixas temperaturas, filões e jazimentos disseminados: a) filões com minerais de Co-Ni-Bi-Ag-As. Algo parecido com os filões de Sn de 
Cornualls; b) filões com pirita e galena; c) filões ricos em fluorita; d) disseminações em rochas metamórficas: com tucolita e ouro; com pirita, monazita e brannerita; e e) em disseminações epigenéticas não oxidadas: filões de substituição em arenitos e conglomerados (tipo Meseta do Colorado), com a) uma associação vanadífera que engloba coffinita e óxidos de vanádio de valência baixa; e b) associação não vanadífera de sulfetos de $\mathrm{Pb}, \mathrm{Cu}, \mathrm{Zn}, \mathrm{Fe}, \mathrm{Co}$ e $\mathrm{Ni}$.

A composição da torianita é $\left(\mathrm{Th}, \mathrm{U}_{4}\right) \mathrm{O}_{2}$. O U4 se oxida em parte ou completamente a U6. Forma uma série, química e estrutural, completa com a uraninita com razão Th : $U=1: 1$. Pequenas quantidades de $\mathrm{Fe}^{3}$ e $\mathrm{Zr}$ podem ser também isomórficas com o Th. Os elementos do grupo do Ce substituem o Th em parte ou completamente (cerianita, $\mathrm{CeO}_{2}$ ). O Pb existente é, provavelmente, radiogênico. Quantidades menores ou traços são: $\mathrm{Ca}, \mathrm{Mn}, \mathrm{Mg}$ e He. A torianita se altera para torogumita facilmente devido à oxidação do $U^{4+}$ a $U^{6+}$ e pela adição de $\mathrm{H}_{2} \mathrm{O}$ e outros elementos. As espécies com elevado teor de tório se alteram menos facilmente do que as mais próximas à uraninita (uranotorianita). A torianita (uraninita torífera) é muito menos comum em pegmatitos do que a uraninita.

\subsection{Geomorfologia Regional e Local}

No contexto geomorfológico do estado da Bahia (Figura 2.15) a área de interesse está inserida nos compartimentos regionais de relevos denominados de Serra Geral do Espinhaço e Depressão Periférica e Interplanar.

Segundo Geocervices (2004), o Compartimento Regional Serra do Espinhaço engloba o conjunto de serras, patamares e pediplanos da denominada Serra do Espinhaço, com alinhamento N-NW/S-SE, e sustentada por rochas metassedimentares e metaígneas de idade Mesoproterozoica. Pode ser subdividida em 2 unidades geomorfológicas:

a) Pediplano Cimeiro

Superfície de aplainamento instalada em cotas altimétricas elevadas (900 a 1000 metros), conhecidas como "Gerais" e exposta entre Caetité e Maniaçu.

b) Patamares Marginais

Constituído por blocos rochosos com topos quase planos, com feições estruturais salientes e intensa dissecação do relevo (ex. Serra da Jurema, entre Caetité e São Timóteo). 


\section{RELEVO}

\section{Estado da Bahia}

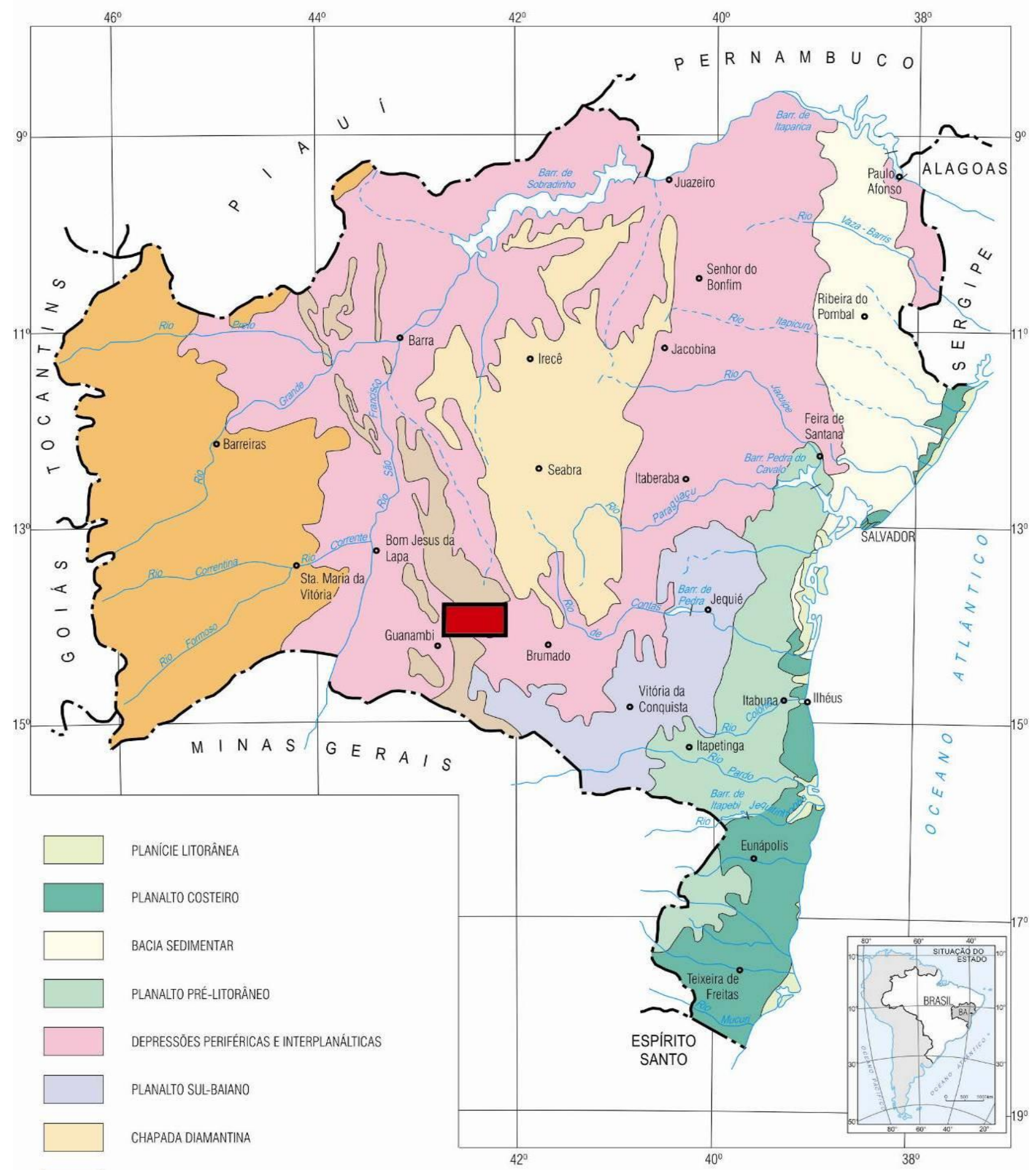

SERRA GERAL DO ESPINHAÇO

CHAPADÃO OCIIENTAL DO SÃo FRANCISCO

Localização da área de estudo extendida

$\frac{130 \mathrm{~km} .}{65}$

Fonte: Radambrasil, 1983.

Figura 2.15 - Mapa de relevo do estado da Bahia. Entenda-se por "'área estendida" a região abrangendo as localidades de Caetité, Lagoa Real, Maniaçú, Complexo Mínero-industrial e São Timóteo (modificado de Superintendência de Estudos Econômicos do Estado da Bahia - SEl- 2007). 
A Depressão Periférica e Interplanática compreende os pediplanos e serras residuais da bacia do rio de Contas, construídas pela erosão das rochas metamórficas de idade Arqueana a Paleoproterozoica. É subdividida em:

\section{a) Pediplano Sertanejo}

Representa a superfície de erosão associada aos processos de pediplanação que atuaram sobre as rochas do Complexo Metamórfico-Migmatítico Lagoa Real, aparecendo na região de Lagoa Real, Ibiassucê e rio do Antônio.

b) Pedimentos

Compreendem os relevos planos a suavemente inclinados que se desenvolvem pelo recuo das vertentes montanhosas (observado na região de São Timóteo, sobre as litologias dos Complexos Metamórfico e Lagoa Real).

\section{c) Serras Residuais}

Representado pelas elevações residuais que resistiram aos processos erosivos que geraram o Pediplano Sertanejo. Exemplos podem ser vistos na região de Lagoa Real e à leste de São Timóteo. Localmente na área de estudo, de acordo com Lamego et al., (2003), o maciço de Caetité é limitado geomorfologicamente, ao norte e ao sul, respectivamente por superfícies aplainadas de Paramirim e Caculé. As altitudes variam de 750 a $1.100 \mathrm{~m}$, sendo o relevo colinoso, modelado pela ação erosiva dos rios São João e Paramirim, que progressivamente avançam sobre o platô de Maniaçú, correlacionável ao ciclo Sul-americano.

Existem três unidades principais de relevo: plano, encostas e baixadas aluvionares. A Unidade Relevo Plano ocupa a porção topográfica mais elevada da área, com declividades inferiores a 10\% e sustentada por litologias graníticas e álcali-gnáissicas. A Unidade Encosta ocupa a porção topográfica intermediária entre os topos planos e as baixadas, possuindo declividade variável entre 10 a $20 \%$, e apresentam vertentes desenvolvidas sobre rochas do tipo granítico e gnáissico. As vertentes exibem morfologia do tipo retilínea suave, convexa e raramente côncava. A Unidade Baixadas Aluvionares ocupa as calhas dos vales e planícies de inundação das principais drenagens da região (Lamego et al., 2003).

Já em se tratando da região do semiárido nordestino, de forma abrangente, $85 \%$ do seu espaço total se estende pelas depressões interplanálticas, sob a forma de colinas, cuja composição do material rochoso varia entre xistos e gnaisses, com baixo nível de decomposição química das rochas (Dossiê Nordeste Seco, 1999).

\subsection{Aspectos Meteorológicos}

O clima Semiárido brasileiro é caracterizado pelo balanço hídrico negativo na maior parte do ano, resultante das precipitações médias anuais inferiores a $800 \mathrm{~mm}$ concentradas na estação chuvosa, insolação média de 2800 h.ano $^{-1}$, temperaturas médias anuais de $23^{\circ}$ a $27^{\circ} \mathrm{C}$. Estende-se, em sua maioria, por grande parte da região Nordeste, além de uma fração do norte de Minas Gerais (Figura 2.16). 


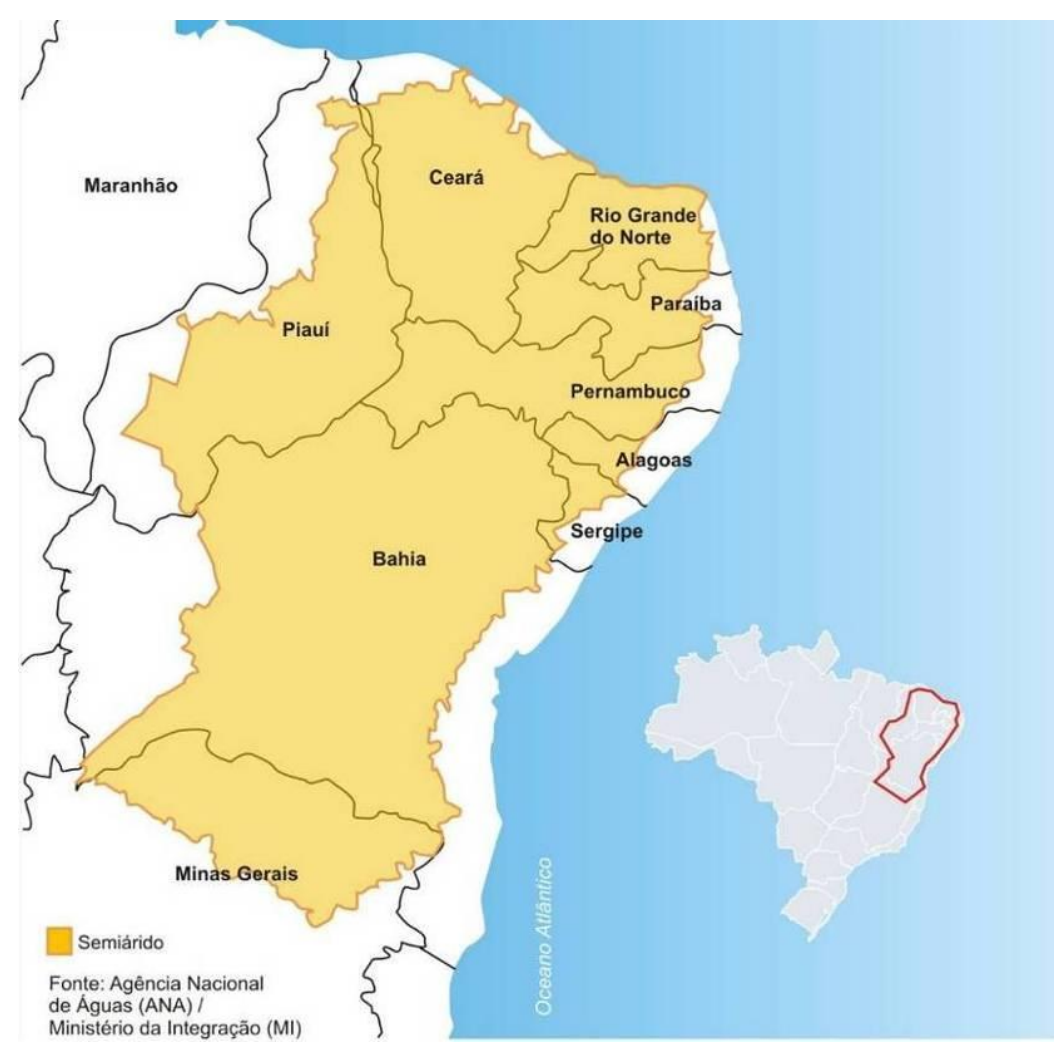

Figura 2.16 - Mapa de distribuição da região de clima semiárido no Brasil (Agência Nacional de Águas - ANA).

Essa região apresenta elevada variabilidade na distribuição espacial e temporal das chuvas, e essa variação compreende um dos principais fatores do desencadeamento das secas, aliada a reduzida capacidade de retenção da água das chuvas pelo solo (Mendes, 1997).

Cabe ressaltar aqui que déficit hídrico não é sinônimo de pouca chuva. O grande problema é a distribuição temporal das mesmas, quando se concentram num curto período do ano, e no restante há balanço hídrico negativo. Nesse sentido, o Semiárido também sofre com enchentes, na estação chuvosa.

O Aquecimento Global, no caso do surgimento de eventos extremos, só agrava esses problemas. Fenômenos como El Niño são responsáveis por piorar as condições habitáveis e de subsistência da população que vive nessas áreas. Esses episódios potencializam as secas e acarretam grandes prejuízos ao cultivo e criação de animais. Os habitantes dessa área são altamente dependentes dos recursos hídricos subterrâneos, tendo em vista que a maior parte dos rios são temporários. Como fonte alternativa, alguns moradores da zona rural captam água de chuva, no período mais úmido.

Tratando-se do local de interesse, a precipitação da região é em média 600 a $800 \mathrm{~mm}$ de chuva por ano, sendo que em Caetité a precipitação média anual é de 797,1 mm/ano, em São Timóteo é de 672,3 mm/ano, e em Maniaçú, de 834,7 mm/ano. As chuvas são concentradas no verão e final da primavera, principalmente nos meses de novembro, dezembro, janeiro e fevereiro. Nessa região o período correspondente ao inverno é o que apresenta a maior redução nos índices pluviométricos (Silva, 2008 e Simões Filho et al., 2006). 


\subsection{Pedologia}

$\mathrm{Na}$ área estudada existem quatro grupos de solo, de acordo com o apresentado em PLANARQ (1997) atualizado de acordo com a classificação atual proposta por Embrapa (2013): Cambissolo eutrófico, Latossolo Vermelho-Amarelo distrófico e associação de Argissolo Vermelho-Amarelo distrófico / Nitossolo Háplico, e gleissolos (Figura 2.17).

\section{Cambissolo Háplico Eutrófico}

São solos de textura média, argilosa ou muito argilosa comprofundidade rasa a moderada. O horizonte A é normalmente raso a moderado, com espessura entre 10 e $25 \mathrm{~cm}$, e cor amarelo-avermelhado a vermelho amarelado. O horizonte Bi já é mais espesso (30 a $80 \mathrm{~cm}$ ), sem gradiente textural, e segue-se um horizonte $C$ de alteração de rochas graníticas e gnáissicas. Essa classe é dividida em duas subclasses, de acordo com o grau de declividade do terreno: os cambissolos eutróficos em áreas de relevo suave a ondulado e os cambissolos eutróficos em áreas de relevo ondulado a fortemente ondulado (PLANARQ, 1997).

O potencial erosivo destes solos é limitado pela presença de ampla pedregosidade que se destaca como uma camada superficial rica em cascalhos de quartzo de veio. Quando esta camada é removida o potencial erosivo é ampliado de forma significativa, principalmente sob fluxo de escoamento superficial concentrado.

\section{Latossolo Vermelho-Amarelo}

De acordo com PLANARQ (1997), a classe do Latossolo Vermelho-Amarelo compreende solos profundos ou muito profundos (profundidade efetiva maior que 1 metro), textura muito argilosa, argilosa a média, e saturação de bases baixa a extremamente baixa. Apresentam horizonte A normalmente moderados $(20$ a $30 \mathrm{~cm}$ ), horizonte $B$ de cores amarelo-avermelhado a vermelho amarelado.

O potencial erosivo é naturalmente limitado em função da declividade dos terrenos inferiores a $5 \%$ nas áreas de ocorrência destes solos. Entretanto, quando submetidos a concentração de fluxo os processos erosivos podem produzir sulcos e ravinas.

\section{Associação de Argissolo Vermelho-Amarelo e Nitossolo Háplico}

Tratam-se de solos profundos, apresentando os horizontes A, Bt ou Bn e C. Apresentam horizonte $A$ normalmente moderados $(20$ a $40 \mathrm{~cm}$ ), de textura arenosa, média e argilosa; horizonte B espesso (1 a 2 m) e de gradiente textural variável de 30 a 60\%, com textura argilosa a média e cores vermelho amarelado a amarelo-avermelhado. Essa associação de solos é dividida em subclasses, de acordo com a declividade do terreno: os solos podzolizados em áreas de relevo suave a ondulado e os solos podzolizados em áreas de relevo ondulado a forte ondulado, PLANARQ (1997). A rochosidade é uma feição comum desta associação de solos. 


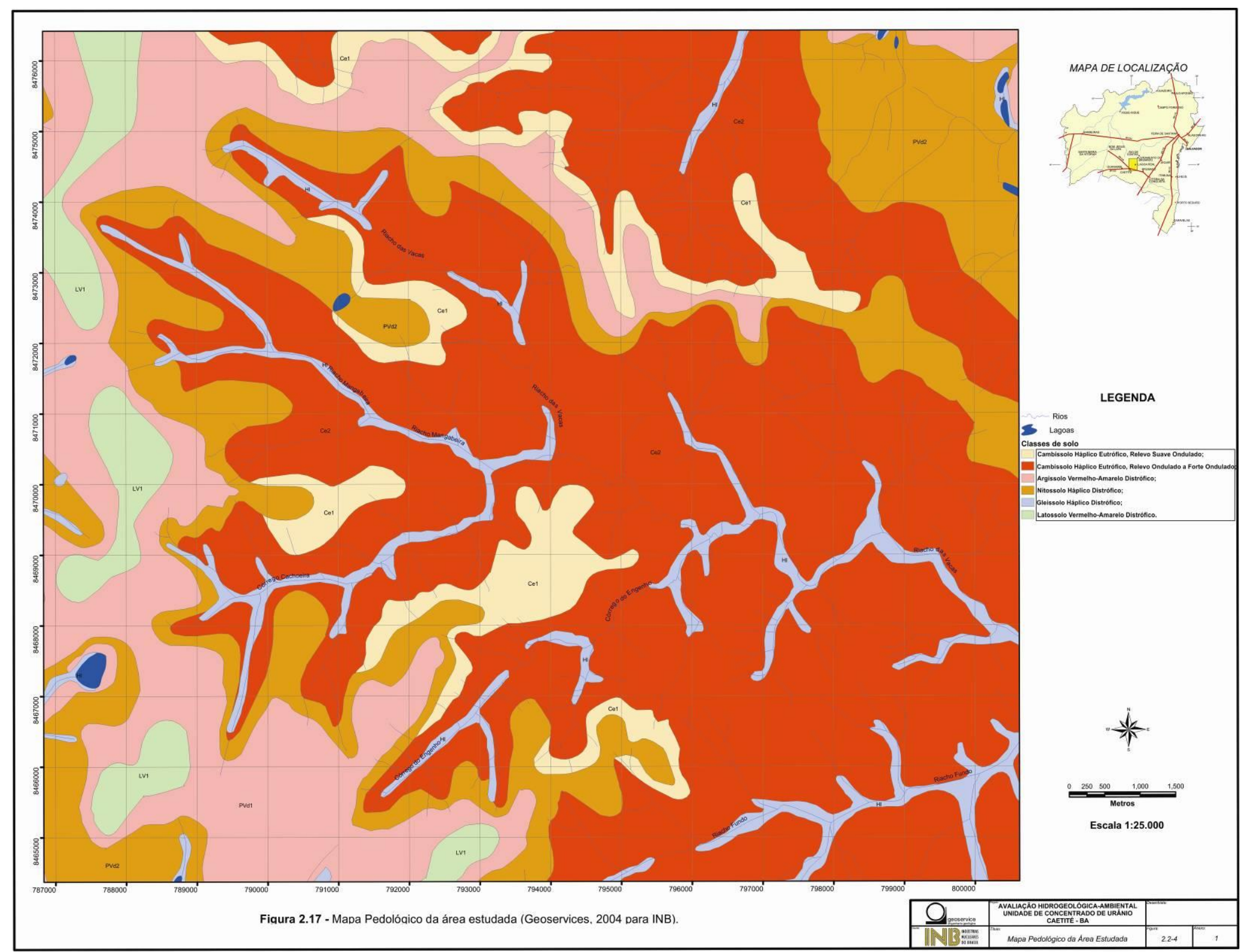


Os processos erosivos são comumente observados nesta associação de solos, principalmente em áreas de agricultura e pecuária, devido ao relevo e textura associada a estas classes de solos.

\section{Solos Hidromórficos Indiscriminados}

Compreende solos minerais, hidromórficos, cuja característica é a presença o horizonte $B$ glei, de cor cinzenta, à no máximo $50 \mathrm{~cm}$ da superfície. São medianamente profundos, mal a muito mal drenados, que ocorrem nas calhas dos principais cursos d'água da área (principalmente nas cabeceiras). São desenvolvidos a partir de sedimentos recentes, PLANARQ (1997). Essa classe não foi encontrada durante as atividades de campo nas áreas circunvizinhas ao empreendimento minerário, entretanto foram observadas em restritas manchas nos estudos de geologia regional.

Durante as atividades de campo pode-se observar que, nas regiões de relevo plano, nos topos onde encontra-se a área da mineração, a cobertura de solos apresenta-se pouco espessa e pouco evoluída (Figura 2.18). Pode-se distinguir apenas uma camada de solo sobreposta ao substrato rochoso e, raramente, visualiza-se um misto de rocha alterada e horizonte $\mathrm{C}$ coberto por um nível de horizonte $A$, mantendo as características do protolito. Nas drenagens, às margens dos rios, ocorrem depósitos aluvionares com seixos em matriz suportada. A matriz é composta por areia muito grossa, que denota regime de tração de alta energia.

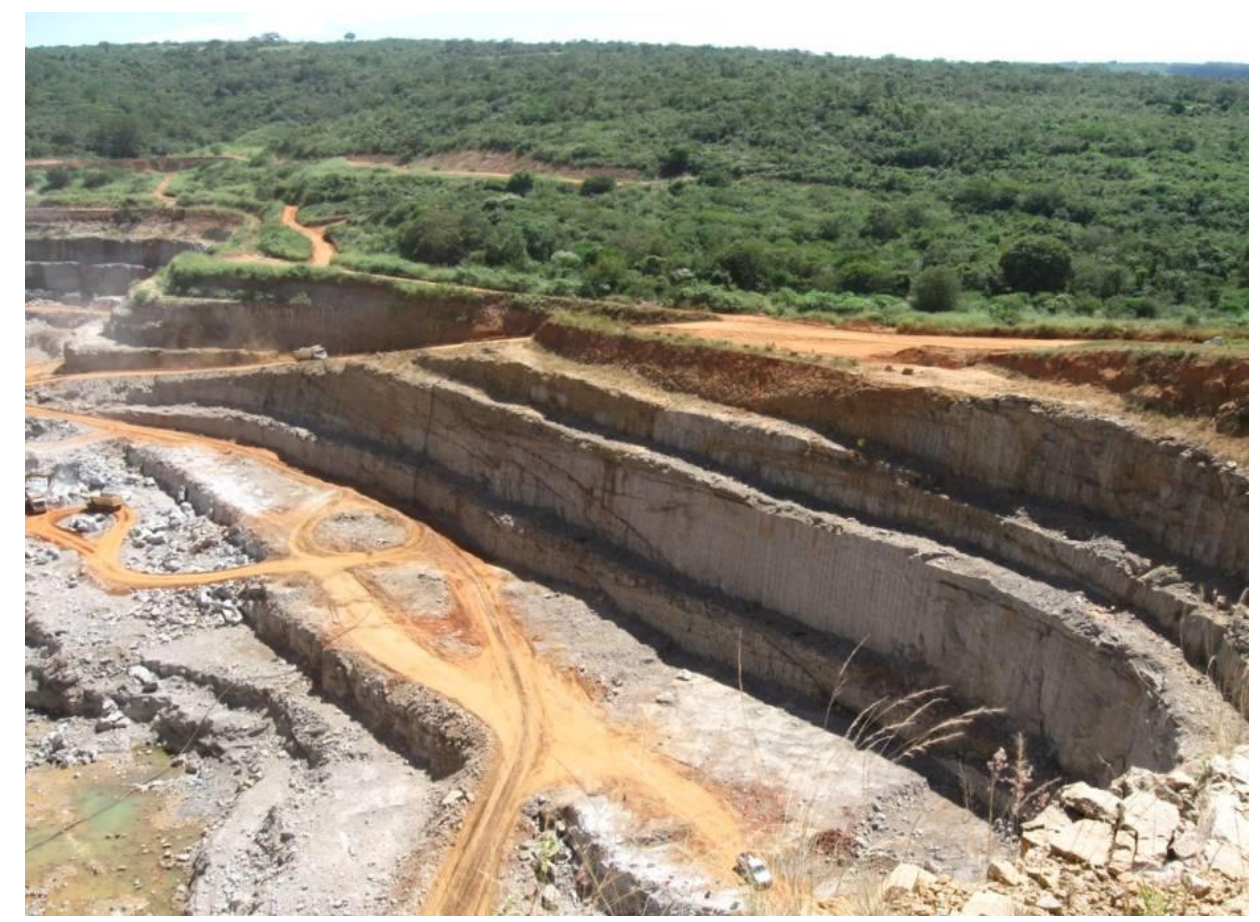

Figura 2.18 - Fotografia onde se pode observar a transição entre solo e rocha, ao longo dos afloramentos expostos graças a cava da mina (Campo realizado em 2007). 


\subsection{Hidrografia}

As características climatológicas e hidrológicas supracitadas, associadas a conformação do relevo regional com escoamentos para vertente atlântica, dão origem a uma rede hidrográfica na qual são recorrentes os cursos com nascentes intermitentes, cuja descarga ocorre apenas durante restritos períodos de chuva torrencial (Simões Filho et al., 2003).

As drenagens exibem controle geológico, possuindo preferencialmente orientação NWSE, e secundariamente SW-NE (padrão retangular). O controle geológico-estrutural das drenagens é observado em quase todas elas, mas principalmente no alto curso dos riachos Fundo, Mangabeira, das Vacas e Córrego do Engenho. Na borda leste do domínio geomorfológico, as drenagens exibem padrão dendrítico (PLANARQ, 1997).

A bacia mais importante na área de estudo é a bacia hidrográfica do Riacho das Vacas, até as proximidades de sua afluência ao Riacho Fundo; e esta bacia está inserida na Bacia Hidrográfica do Rio de Contas (Geosesvices, 2004).

O Riacho das Vacas é afluente da margem esquerda do Riacho Fundo; este último é afluente da margem esquerda do Rio São João, que é afluente da margem direita do Rio Brumado, e este, por sua vez, deságua na margem direita do Rio de Contas (Figura 2.19).

O Riacho Fundo, como os outros rios que afluem para o Rio Brumado, têm suas nascentes nas vertentes da Serra do Espinhaço Setentrional, correndo preferencialmente de oeste para leste.

Como a bacia hidrográfica do Rio Brumado está em uma zona de grande restrição pluviométrica, a contribuição (de água) desta bacia para o Rio de Contas ocorre principalmente nas épocas de chuvas intensas (Geoservices, 2004), sendo que na maior parte do tempo as drenagens exigem leito seco (Figura 2.20). 


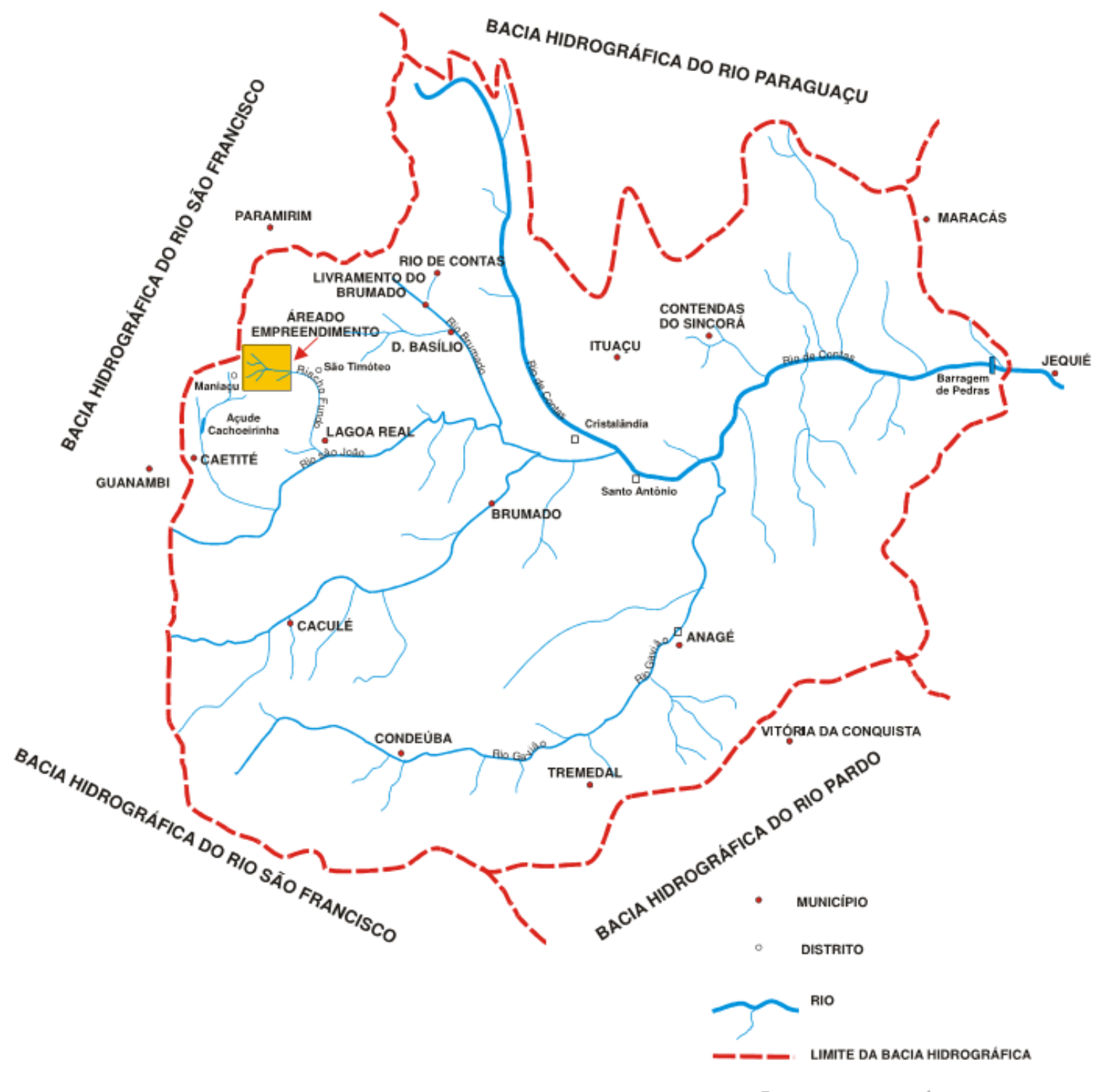

Figura 2.19 - Bacia Hidrográfica do Rio de Contas (Indústrias Nucleares do Brasil).

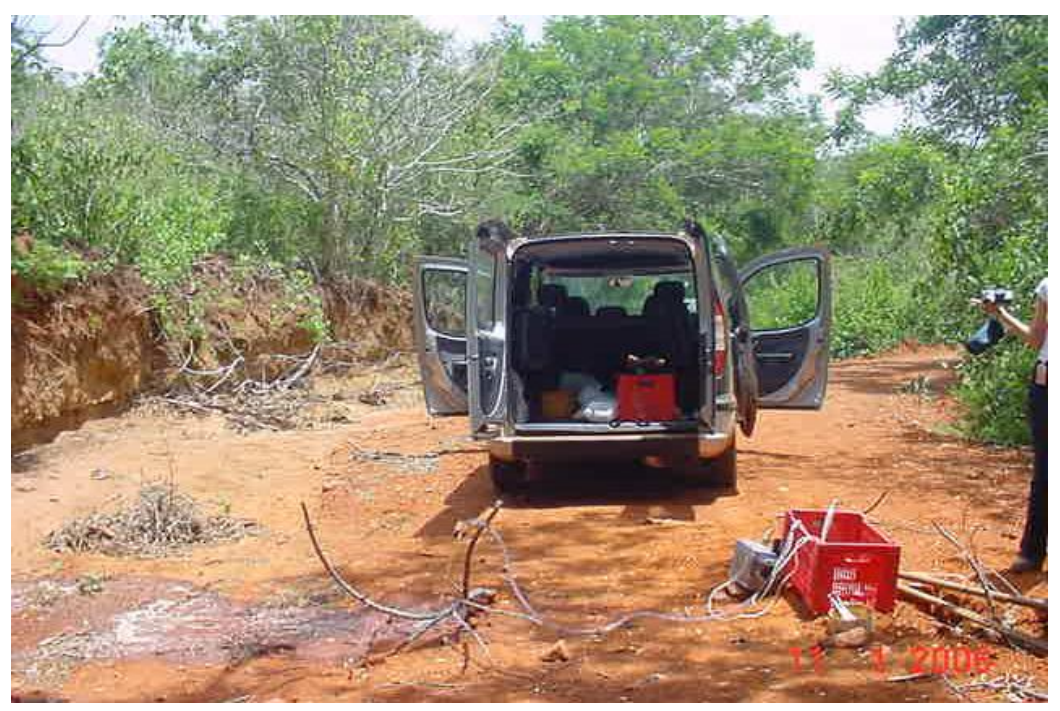

Figura 2.20 - Leito do Córrego do Engenho (Visita realizada em janeiro de 2006). 


\subsection{Mecânica de Rochas}

Do ponto de análise da mecânica de rochas, desconsiderando as classificações petrológicas distintas, os litotipos encontrados na área de estudo correspondem a gnaisses e granitos.

Os granitos são as rochas ígneas de maior variedade de aplicações na engenharia, por apresentarem baixíssima porosidade primária e elevada resistência mecânica. Essas propriedades o tornam um material com múltiplas aplicações, desde uso como agregado, blocos, placas serradas, placas polidas (rocha ornamental), e também "in situ" como material de autosuporte, para construção das mais diversas obras, tais como barragens, túneis, taludes artificiais, dentre tantas outras. Os gnaisses são muito semelhantes aos granitos, no que se refere às propriedades geomecânicas, contudo podem apresentar planos preferenciais que diminuem a resistência do material para certas aplicações.

Dentre os estudos em desenvolvidos para caracterização do aquífero em questão, o levantamento sistemático das descontinuidades compreendeu uma das etapas fundamentais à elaboração do modelo conceitual. Por descontinuidade entendem-se todas as estruturas que rompem a continuidade do maciço, ou seja, segundo Oliveira et al., (1998) todas as feições geológicas que representam ou induzem zonas de fraqueza mecânica e vias de percolação preferencial no interior das massas rochosas. Sendo assim, percebe-se que juntas, falhas, discordâncias, foliação, planos de acamamento, etc., podem conferir descontinuidades ao maciço, considerando a matriz rochosa (caso de rochas ígneas e metamórficas) contínua, do ponto de vista geomecânico.

Em se tratando do sistema aquífero fraturado estudado, a presença de fluxo das águas subterrâneas ocorre através das descontinuidades. Essas estruturas conferem porosidade secundária ao maciço rochoso, e graças à intersecção entre elas existe a comunicabilidade do aquífero (Figura 2.21).
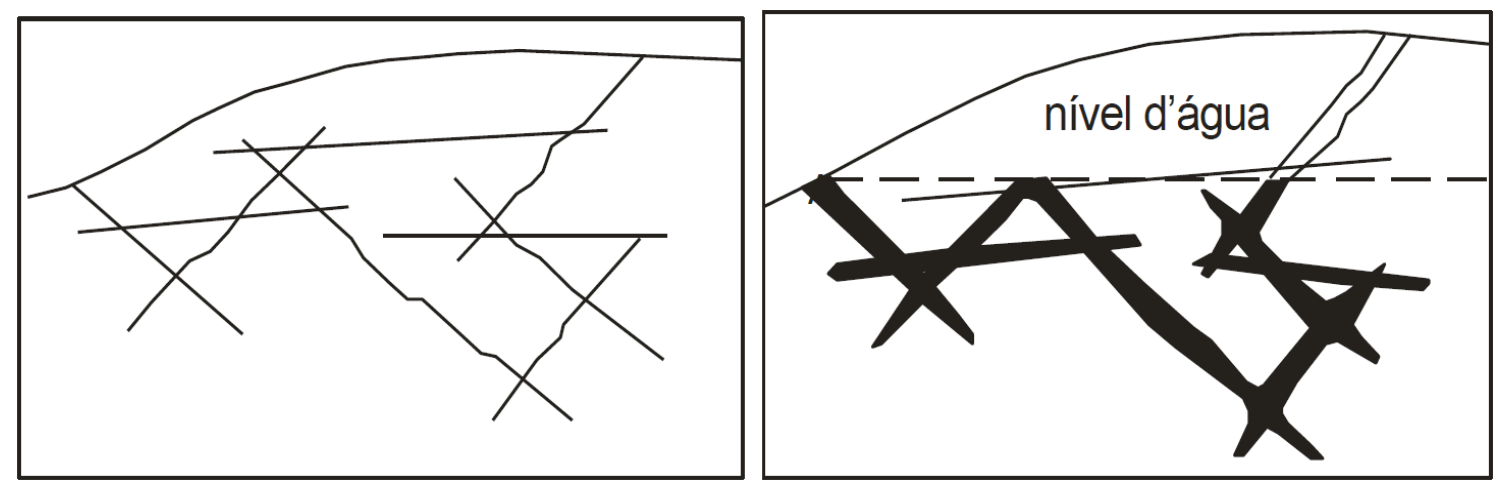

Figura 2.21 - Ilustração esquemática do aquífero fraturado. Observa-se exemplo da organização espacial das estruturas, e de como se dá o acúmulo de água (Silva, 2008). 


\subsection{Aspectos Socioeconômicos}

Ab' Sáber (1999), o Semiárido brasileiro é a área semiárida mais povoada do mundo e, em função das adversidades climáticas, aliadas a outros fatores históricos, geográficos e políticos, que remontam centenas de anos, abriga a parcela mais pobre da população brasileira.

Tal qual já citado, nessa região, devido ao acentuado déficit hídrico, a ampla maioria dos corpos d'água são temporários. Desse modo, tanto a população rural, quanto urbana são fortemente dependentes dos recursos hídricos subterrâneos.

Segundo o Instituto Brasileiro de Geografia e Estatística (IBGE, 2015) a renda per capita mensal da população rural, do município de Caetité/Bahia é de $R \$ 162,00$ (cento e sessenta e dois reais), contra RS 350,00 (trezentos e cinquenta reais) em se tratando da mesma renda, no caso da população urbana. A economia é sustentada pelo setor de serviços (Figura 2.22).

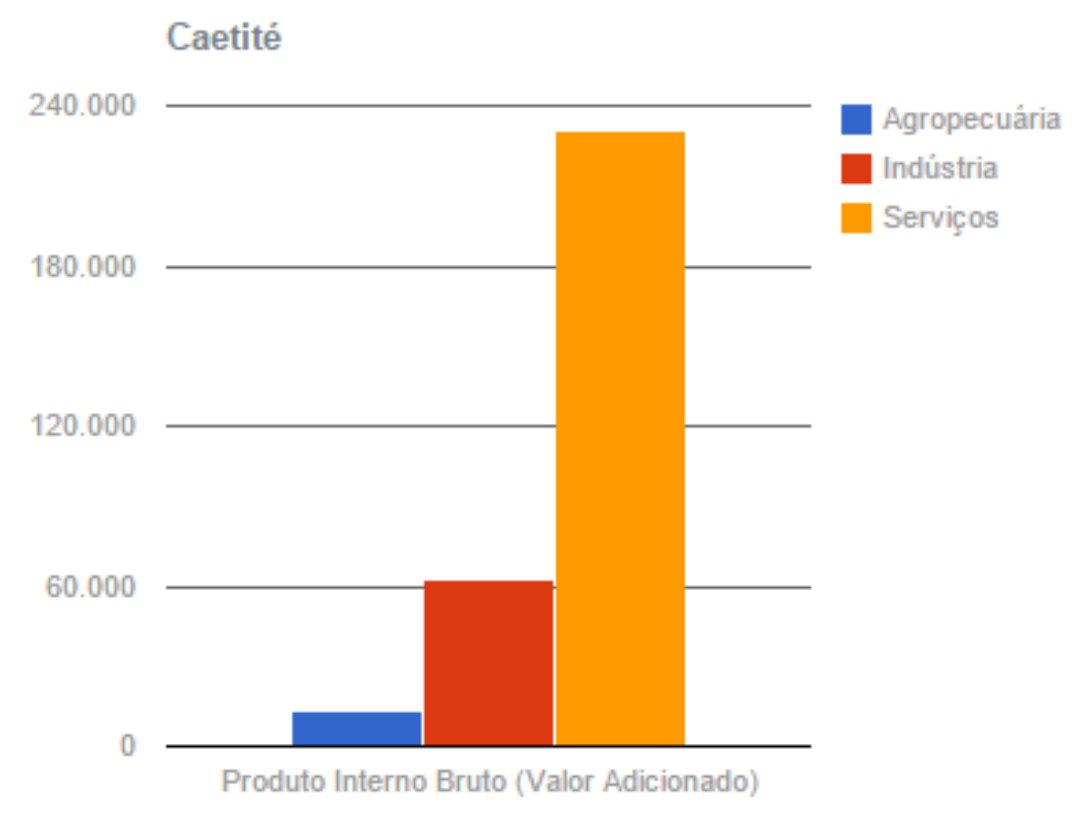

Figura 2.22 - Produto Interno Bruto do Município de Caetité (IBGE, 2015).

Graças a programas governamentais para construção de poços de abastecimento e instalação de cisternas para captação de água de chuva, pode-se observar nas visitas a campo o desenvolvimento de atividades agrícolas, principalmente nos fundos dos vales, nas localidades de Caetité, Maniaçú, São Timóteo e Lagoa Real (Figuras 2.23, 2.24, 2.25 2.26).

Já outras iniciativas não obtiveram tal êxito, a exemplo da tentativa de implantação de dessalinizadores. Tanto na área de estudo, quanto no norte de Sergipe e sul de Alagoas, o que se pode observar foram estruturas abandonadas, sem manutenção pelo poder público. Os poucos que ainda estão em funcionamento, ou foram construídos em propriedades privadas ou a população assumiu o custo para manutenção de seu funcionamento (Figura 2.27). 


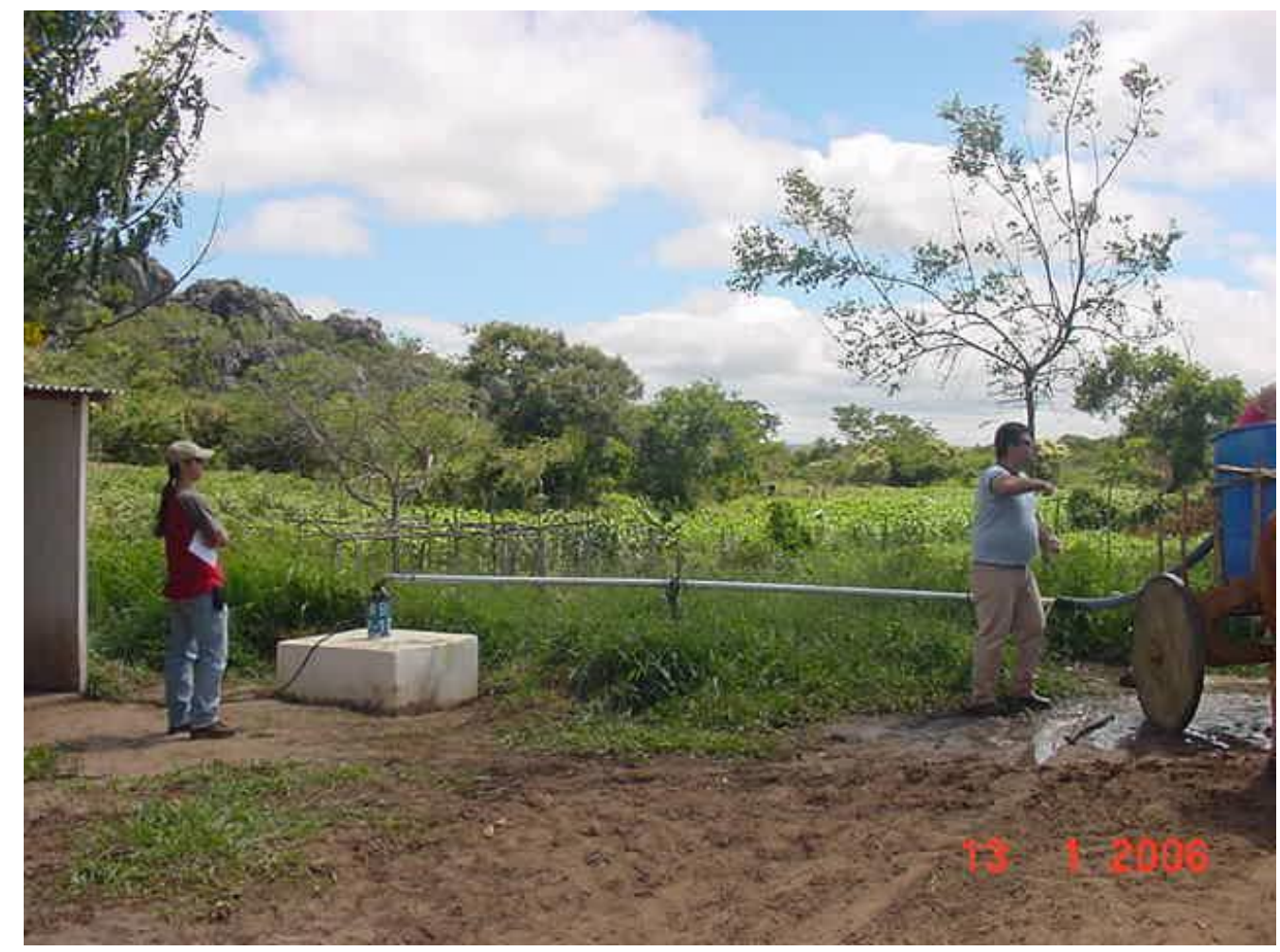

Figura 2.23 - Poço construído para abastecimento da população em São Timóteo.

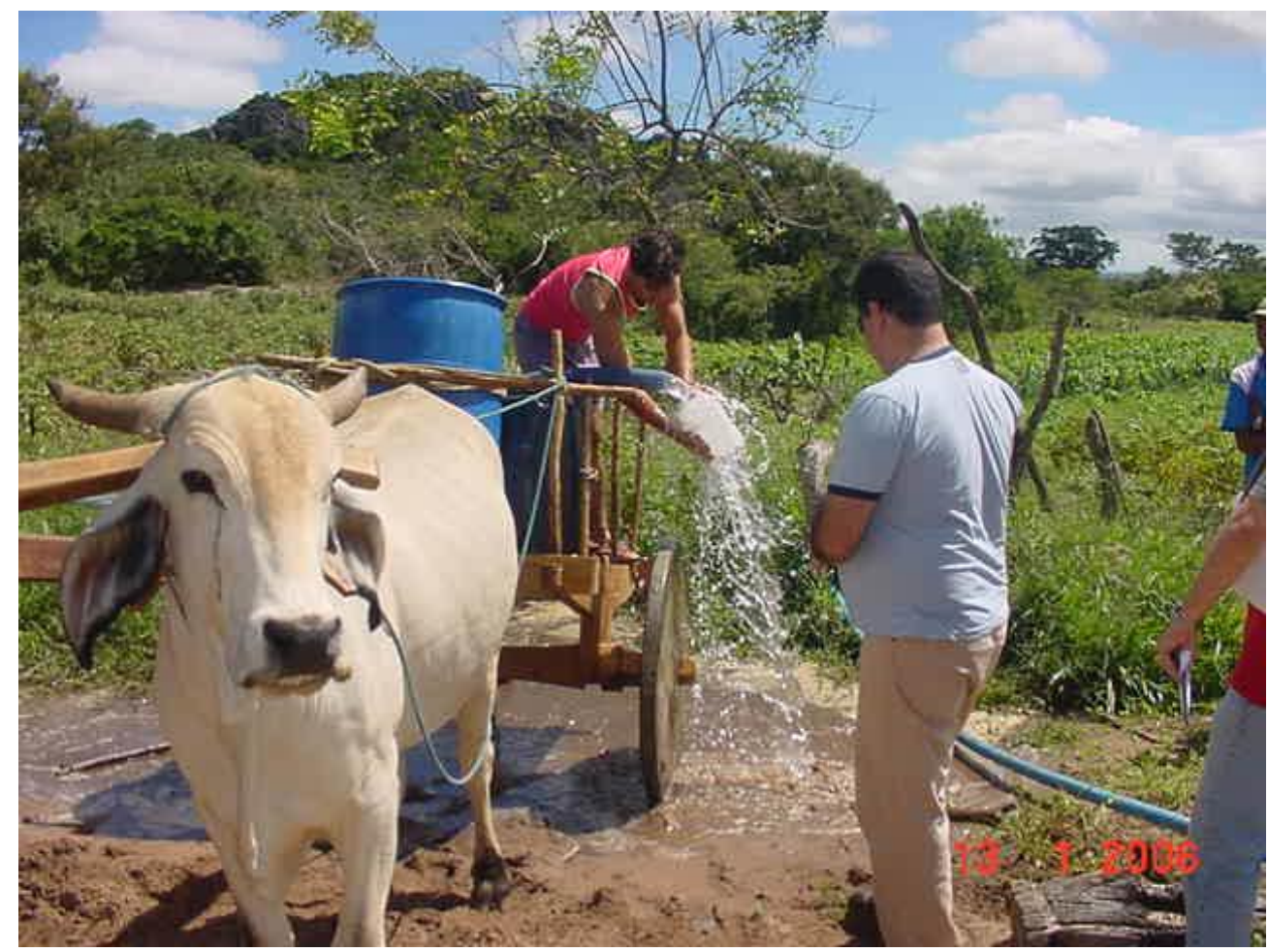

Figura 2.24 - Abastecimento através de poço de captação. 


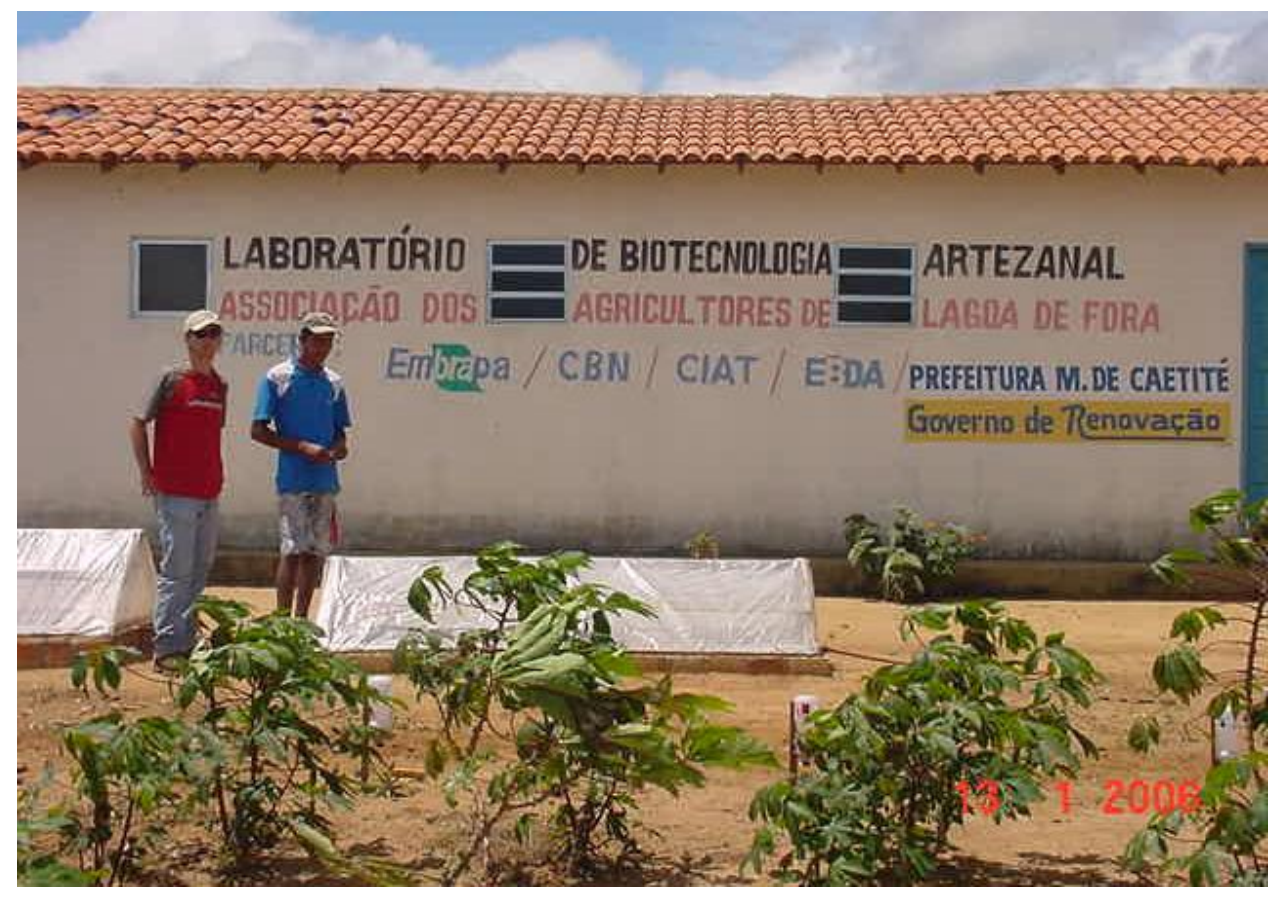

Figura 2.25 - Projeto para o desenvolvimento de mudas e irrigação.

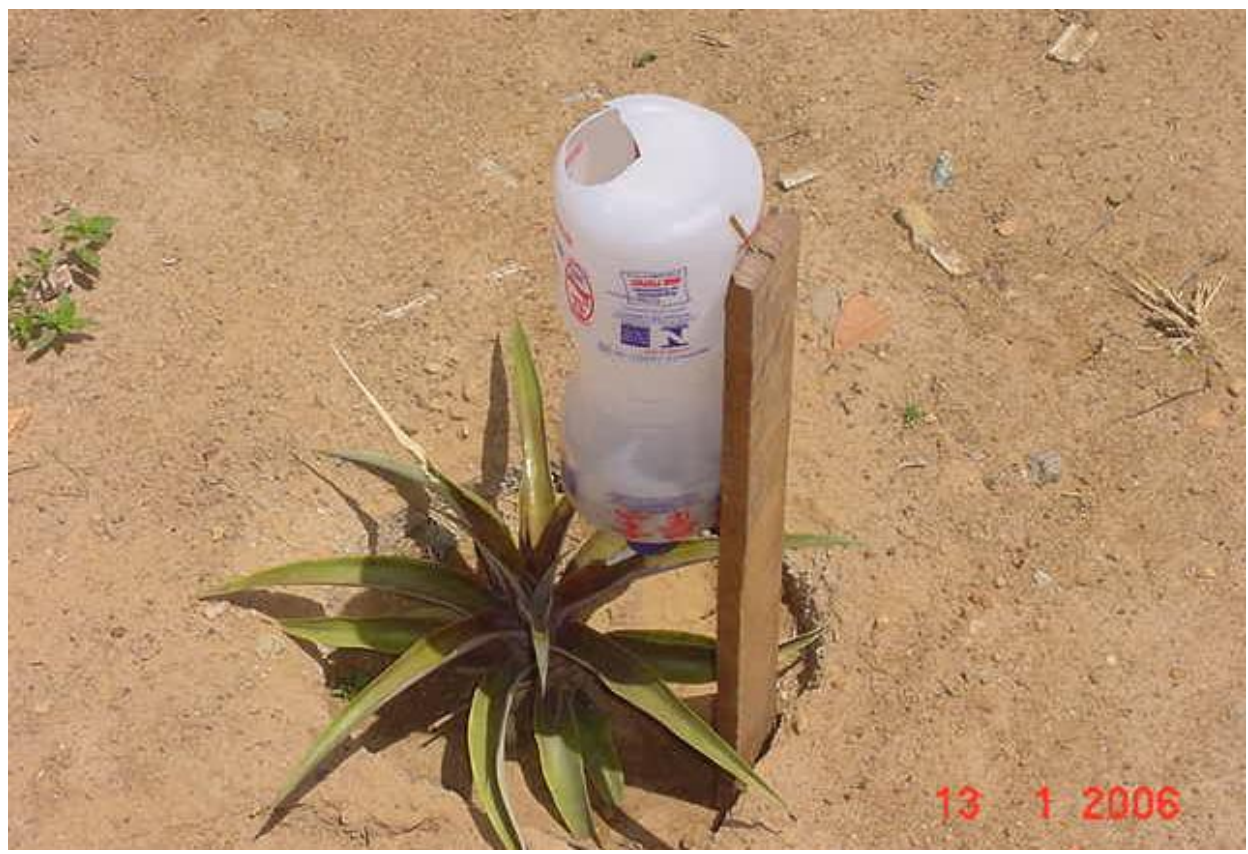

Figura 2.26 - Projeto para o desenvolvimento de mudas e irrigação.

De acordo com os tópicos já tratados neste capítulo, percebe-se que a água subterrânea é o recurso natural mais fundamental a subsistência da população do semiárido. Sendo assim, muitos conflitos pelo uso da água ocorrem, inclusive na área de estudo. A construção indiscriminada de poços, sem que se conheça a potencialidade do aquífero que o poço explota e sem a devida preocupação técnica, pode causar interrupções na oferta (Simões Filho et al., 2003) e ampliar os risco de contaminação. O resultado disto é a criação de conflitos de uso, especialmente quando a questão da distribuição não é equacionada de forma satisfatória (Simões Filho et al., 2006). 


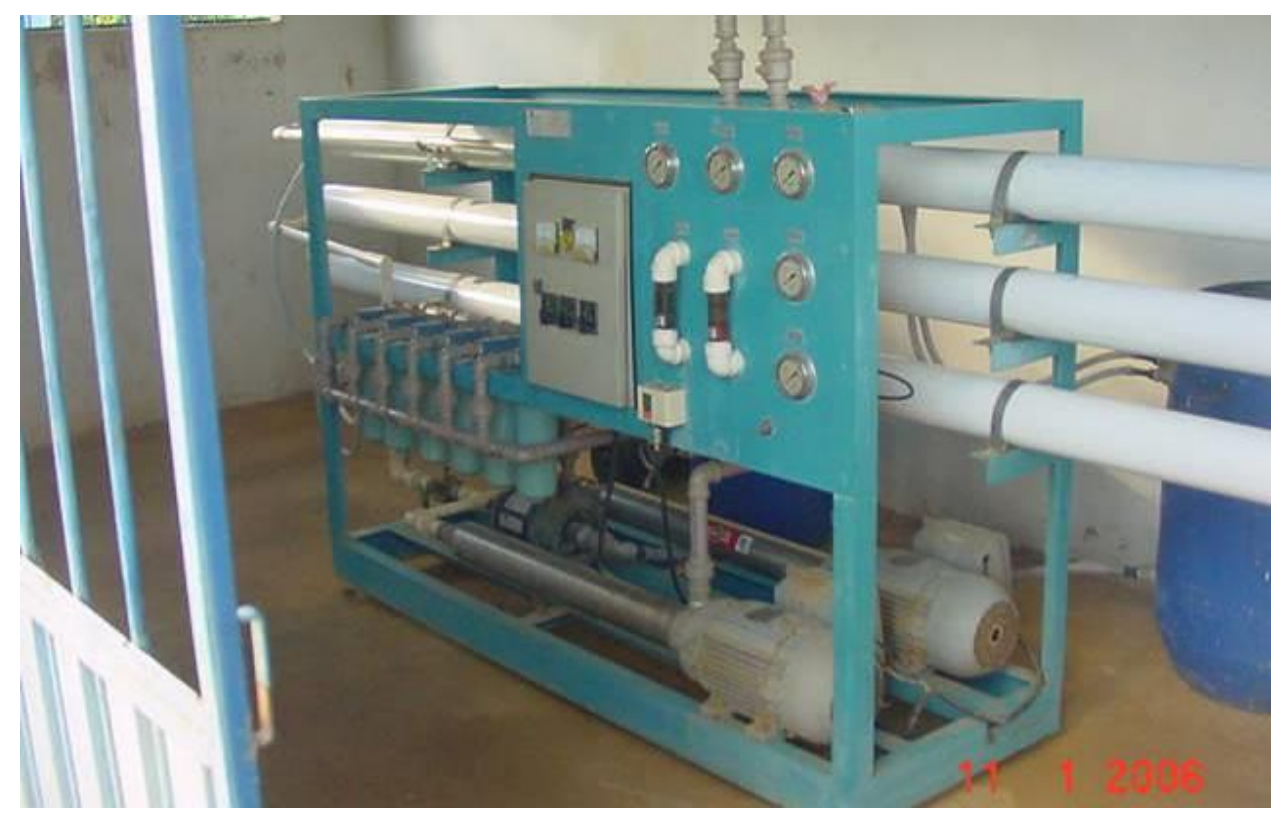

Figura 2.27 - Dessalinizador em funcionamento na localidade de São Timóteo (campo, 2006).

Entretanto, especialmente nesta área, existe um fator agravante dentro dos múltiplos usos da água, que inclui usos vinculados a mineração de urânio. Se por um lado, todo o complexo tenha sido projetado para não liberar efluentes líquidos para o meio ambiente (incluindo drenagem do escoamento superficial da água das chuvas), por outro lado a desinformação, ou o mau uso da informação, agravam ainda mais os problemas socioambientais. Em função do impacto negativo que a radioatividade exerce na população, já fragilizada e vítima de tantos problemas sociais, o medo de contaminação desses recursos hídricos resulta em um problema que foge estritamente do aspecto ambiental, e passa a ter cunho político-econômico.

Ressalta-se que, toda a região, independente da atividade da mineração, representa uma área anômala para urânio, em relação a crosta terrestre. Nesse sentido, concentrações desse elemento nas águas subterrâneas correspondem, fundamentalmente, a lixiviação exercida pelas águas nessas rochas. Se os valores encontrados nessa área forem comparados com outros locais do planeta, que geologicamente não representem anomalia para urânio, as concentrações observadas na área de estudo serão muito mais elevadas.

Diante do exposto, o conhecimento do sistema aquífero fraturado é fundamental, tanto para a exploração mineral, quanto para prover informação e esclarecer as dúvidas da população a respeito da possibilidade de contaminação dos aquíferos pela atividade de mineração, e principalmente, sobre o contexto geológico no qual a região se encontra, e o impacto que ele exerce no processo de formação dos solos e na qualidade das águas subterrâneas. 


\section{CAPÍTULO III}

\section{CARACTERIZAÇÃO DO SISTEMA AQUÍFERO - MODELO CONCEITUAL}

\subsection{Introdução}

O estudo do maciço rochoso, seja para implementação de obra que altere o seu estado de tensões, ou para captação de recursos hídricos e até para uso como agregado requer o estabelecimento de propriedades que retratem o seu grau de qualidade, intrinsecamente ligado as possíveis formas de uso. Nesse caso, o exame minucioso das descontinuidades é fundamental, tendo em vista que elas são as grandes responsáveis pela heterogeneidade e isotropia do maciço rochoso e em última análise respondem pela qualidade do maciço como reservatório de água, pela estabilidade de taludes e pela capacidade de suporte de carga.

Segundo Goodman (1989), a mecânica de rochas é vital para as obras de engenharia em rocha. Desde os anos de 1960 ela foi organizada em disciplina específica e cursos nos programas de engenharia, em virtude das demandas de atividades de engenharia em rocha, tais como: instalações de complexos subterrâneos, construção de túneis, cortes profundos para vertedouros e minas a céu aberto, dentre outras aplicações. Trata-se de uma ciência teórica e aplicada que estuda o comportamento mecânico das rochas e maciços rochosos e a resposta desses materiais quando sujeitos à ação de esforços que alterem seu estado de tensões.

Ainda, de acordo com Goodman (1989), as aplicações da mecânica das rochas podem ser divididas, no que diz respeito às obras de engenharia, em "Atividades de Superfície" e "Atividades em Profundidade". As primeiras referem-se a fundações de edifícios e estruturas em geral, fundações de barragens, estradas, cortes em geral, minas a céu aberto, túneis próximos a superfície, dentre outros. As segundas relacionam-se a minas em profundidade, túneis para uso civil, câmaras subterrâneas, indústria petrolífera, disposição de lixo nuclear, dentre outros.

\subsubsection{Propriedades mecânicas das rochas}

A homogeneidade é uma medida da continuidade física de um corpo. Num material homogêneo qualquer parte do corpo terá as mesmas propriedades em todas as direções. Quando há variações os corpos são denominados heterogêneos

Isotropia é uma propriedade direcional de um material, significa que as propriedades não variam com a direção. Nos casos em que há variações tridimensionais de propriedades os maciços são ditos anisotrópicos.

Os maciços rochosos são, de forma geral, heterogêneos e descontínuos por causa da presença de descontinuidades em várias escalas. 


\subsubsection{Estado de tensões do maciço rochoso}

Segundo Hayett et al., (1986) e Herget (1988) os estados de tensões, aos quais os maciços rochosos estão submetidos, podem ter sua origem atribuída a própria formação desse maciço, ou podem ser induzidos por solicitações antrópicas. A tensão de origem natural, ou tensão in situ, pode ser definida como a tensão resultante da interação entre o peso próprio do maciço, que gera as tensões gravitacionais; o tectonismo, que gera as tensões tectônicas; os efeitos térmicos e os processos físico-químicos, como a precipitação mineral e a recristalização, que estão constantemente modificando a estrutura das rochas. Os movimentos tectônicos afetam o campo de tensões através da criação de falhas, fraturas e dobramentos, que afetados pela erosão, podem gerar um padrão complexo de direção das tensões tectônicas.

As tensões induzidas, de acordo com Hoek \& Brown (1981), são resultado da redistribuição das tensões pré-existentes provocada por alguma solicitação ao maciço, como por exemplo, uma escavação ou a construção de um prédio.

Além destas, a tensão residual é o estado de tensão que permanece no maciço rochoso depois de dissipada a energia e o processo/mecanismo que lhe deu origem. Isso está relacionado às condições de pressão e temperatura do ambiente de formação dessas rochas, que diferem bastante das condições apresentadas pelo ambiente em que elas se encontram atualmente. Os maciços constituídos por rochas metamórficas, por exemplo, podem apresentar estruturas geológicas e conteúdos mineralógicos indicativos de que essas rochas se formaram em grandes profundidades e foram submetidas a altas pressões e temperaturas. Quando, por razões tectônicas ou por erosão, as rochas que se formaram em grandes profundidades se encontram em profundidades menores e submetidas a temperaturas mais baixas, as tensões, em muitos casos, não são totalmente aliviadas, restando ainda esforços "acumulados" nos maciços (as denominadas tensões residuais).

Nesse sentido, podem-se encontrar maciços cujas tensões residuais chegam a superar o acréscimo de tensão solicitado por uma obra. Pode-se citar, por exemplo, um maciço que tenha suportado o acréscimo de tensões do peso de uma geleira (em um período glacial), após uma rápida deglaciação, ele ainda apresenta as tensões residuais referentes ao histórico de tensões a que estava submetido. Outra situação similar pode ser representada por maciços que sofreram ciclos erosivos relativamente rápidos, ou exposição devido à movimento rúptil de soerguimento, tal qual aquele produzido por uma falha.

A presença e o estado das descontinuidades de um maciço (juntas, falhas, juntas preenchidas com argilominerais e etc.), alteram o estado de tensões do maciço rochoso (Goodman 1989). Isso é especialmente relevante na avaliação da resposta do maciço as alterações no estado de tensões, devido a uma obra de engenharia, por exemplo. Assim, grande parte dos estudos em mecânica de rochas foi desenvolvida para prever o comportamento de uma massa rochosa frente a acréscimos de tensões, e solicitações requeridas por obras de engenharia diversas. 
Deste modo, além dos estudos amplamente desenvolvidos pela mecânica de solos e também aplicados a mecânica de rochas, que buscam a resistência ao cisalhamento dos materiais, a caracterização individualizada das descontinuidades tornou-se imprescindível principalmente no que se refere às alterações do estado de tensões do maciço, como resposta a determinada obra de engenharia ou para a determinação dos ângulos máximos de talude de cavas a céu aberto. Contudo, como se constatará mais adiante, o levantamento sistemático das descontinuidades tem aplicações diversas, dentre elas o estudo de aquíferos fraturados.

\subsection{Justificativa para Uso do Método}

Embora fique claro que a mecânica de rochas foi desenvolvida para caracterizar o maciço rochoso, tendo em vista a necessidade de prever seu comportamento quando submetido a solicitações de obras diversas, esses estudos ganharam aplicações das mais variadas. A metodologia de levantamento sistemático das descontinuidades, no que se refere a caracterização quali-qualtitativa, é primordial na elaboração do modelo conceitual do aquífero fraturado em questão. Elas trazem medidas diretas e propiciam a visualização da distribuição espacial dessas estruturas no maciço e sua forma geométrica.

Partindo da premissa que, para tratar de aquífero fraturado é imprescindível conhecer as descontinuidades que o formam (Figura 3.1), a relação matriz rochosa e descontinuidades é fundamental para a caracterização deste tipo de reservatório subterrâneo. A partir daí, pode-se obter outros parâmetros, como a porosidade, condutividade hidráulica, permeabilidade, direção preferencial de fluxo, dentre tantas outras informações hidrodinâmicas.

A existência de fluxo de água subterrânea através de rocha sã de baixa porosidade primária vai depender da densidade, conectividade e abertura das fraturas presentes que são controladas pela tectônica formadora (orogênese) e pela tectônica modificadora (neotectônica) a que a região está submetida.

Nesse sentido, observa-se que na área de estudo as estruturas que compõem o aquífero fraturado não são "apenas" as fraturas, como termo estabelecido nesse trabalho. Além de falhas diversas e juntas que quebram a continuidade do maciço, as zonas de cisalhamento e os próprios planos de foliação (quando alterados) representam zonas de fraqueza também inseridas na classe geral de descontinuidades. Todos estes planos ampliam sua abertura a partir da ação do intemperismo que auxilia na geração de descontinuidades nos maciços rochosos.

Ressalta-se que no caso do exemplo a ser estudado, o levantamento é realizado em escala de detalhe, executado aproveitando a exposição do maciço nas cavas das minas a céu aberto e a variação dos parâmetros com a profundidade, que atualmente alcança em torno de 150 metros. O conhecimento da gênese das estruturas observadas é fundamental para replicar as interpretações para regiões adjacentes, onde a deformação é análoga, mas com carência de afloramentos significativos. 


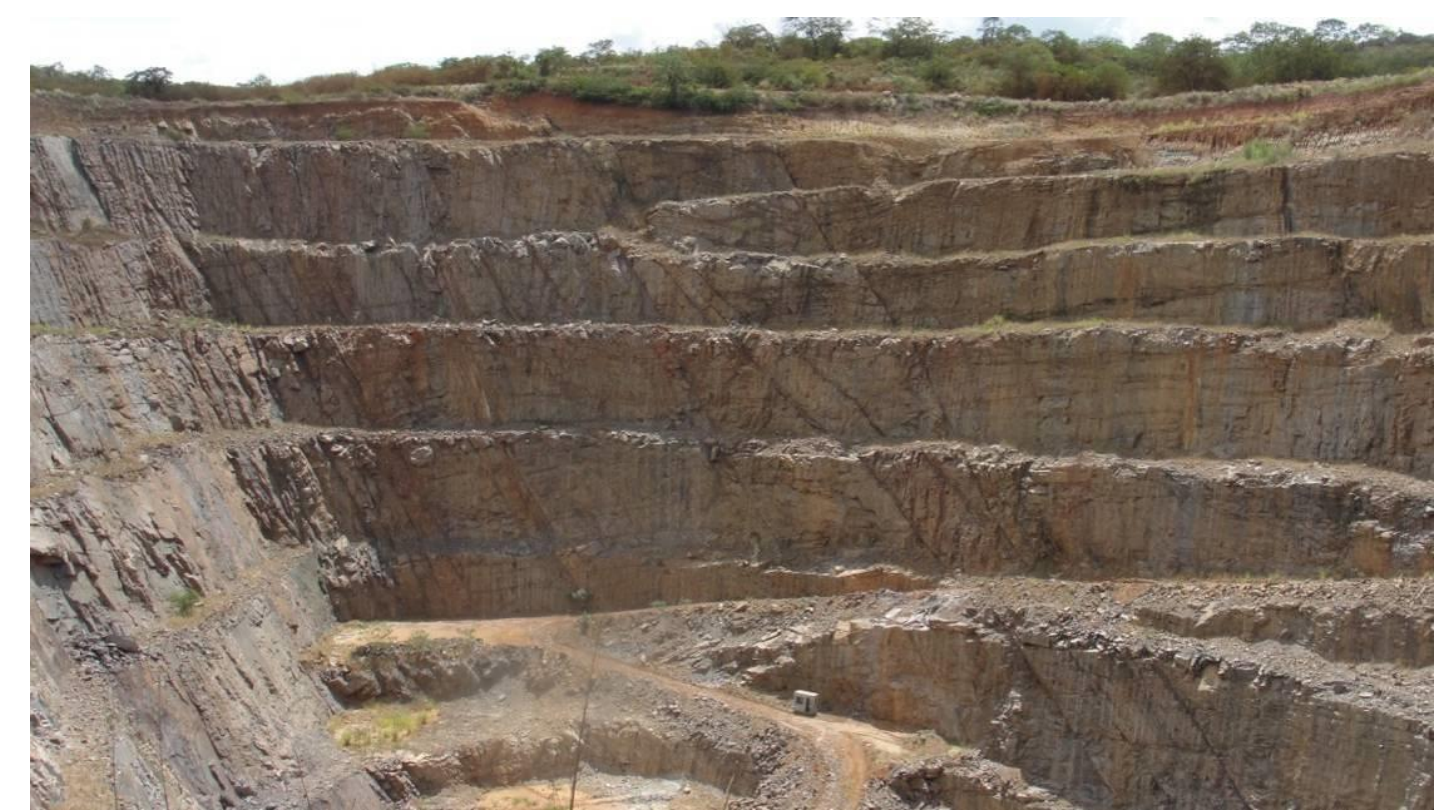

Figura 3.1 - Vista geral do Corpo III onde a casinha branca (na porção inferior central) tem 2 metros de altura.

Já a caracterização das descontinuidades adotada fornece o dado quali-quantitativo das estruturas, possibilitando o entendimento da distribuição espacial e representatividade no maciço. Dessa forma podem-se hierarquizar as famílias de descontinuidades e as suas funções, do ponto de vista do sistema aquífero. Importa ainda frisar que os parâmetros levantados na área serão confrontados com o observado nas adjacências, para ponderar se a alteração do estado de tensões dentro da cava produziu mudanças nas estruturas presentes no maciço.

Finalmente, em se tratando da acumulação e fluxo de água no meio fraturado, usar somente mapeamento estrutural não subsidia a identificação da distribuição das estruturas no maciço, tampouco aquelas que são mais persistentes ou que apresentem maior abertura e são mais propícias ao fluxo de água. Também faltaria mostrar como elas variam com a profundidade. A caracterização geotécnica das descontinuidades levanta parâmetros fundamentais para o entendimento de como essas estruturas funcionam enquanto aquífero.

\subsection{Metodologia}

Segundo a International Society for Rock Mechanics - ISRM (2007), descontinuidade é o termo geral para qualquer descontinuidade mecânica, em um maciço rochoso, que apresenta baixa ou nenhuma resistência à tração. Este é o termo coletivo que pode ser aplicado a maioria dos tipos de juntas, planos de fraqueza do acamamento, planos de fraqueza da xistosidade, zonas de alteração ou de falhas.

As descontinuidades condicionam fortemente as propriedades geotécnicas dos maciços rochosos, conferindo-Ihes um comportamento, em termos de, deformabilidade, resistência ao cisalhamento e permeabilidade substancialmente diferente da rocha que constitui esses maciços. 
De acordo com Jaeger (1979), em se tratando de anisotropia dos maciços rochosos, as propriedades tecnológicas (de resistência ao cisalhamento, por exemplo) dependem muito mais do sistema de separações físicas dentro desse maciço (descontinuidades) do que, propriamente, da resistência do material rochoso. O maciço rochoso é definido como o conjunto formado pela matriz rochosa e por todas as descontinuidades (fraturas, foliações, discordâncias, e etc.) nela contidas. Essas descontinuidades conferem heterogeneidade e anisotropia ao maciço, tendo em vista que a matriz rochosa pode ser considerada, para efeitos práticos, homogênea (Oliveira 1998). Por isso, o estudo e a caracterização de um maciço rochoso deverão, em grande parte dos casos, analisar os seus dois constituintes, ou seja, a matriz rochosa e as descontinuidades.

A caracterização dessas estruturas varia de acordo com a escala de trabalho. Dessa forma, fica claro que a escala da porção do maciço analisada, em um estudo qualquer é fator preponderante na definição da condição do meio, conforme ilustra a Figura 3.2. Dois exemplos de escalas diferentes de trabalho podem ser visualizados quando se compara uma caracterização para fins de conceituação de um aquífero fraturado e a construção de um furo de sondagem raso. No primeiro caso considera-se o maciço numa escala mais ampla, englobando todas as estruturas, já no segundo caso, espera-se que a parte amostrada represente uma escala de maior detalhe e consequentemente, menos abrangente.

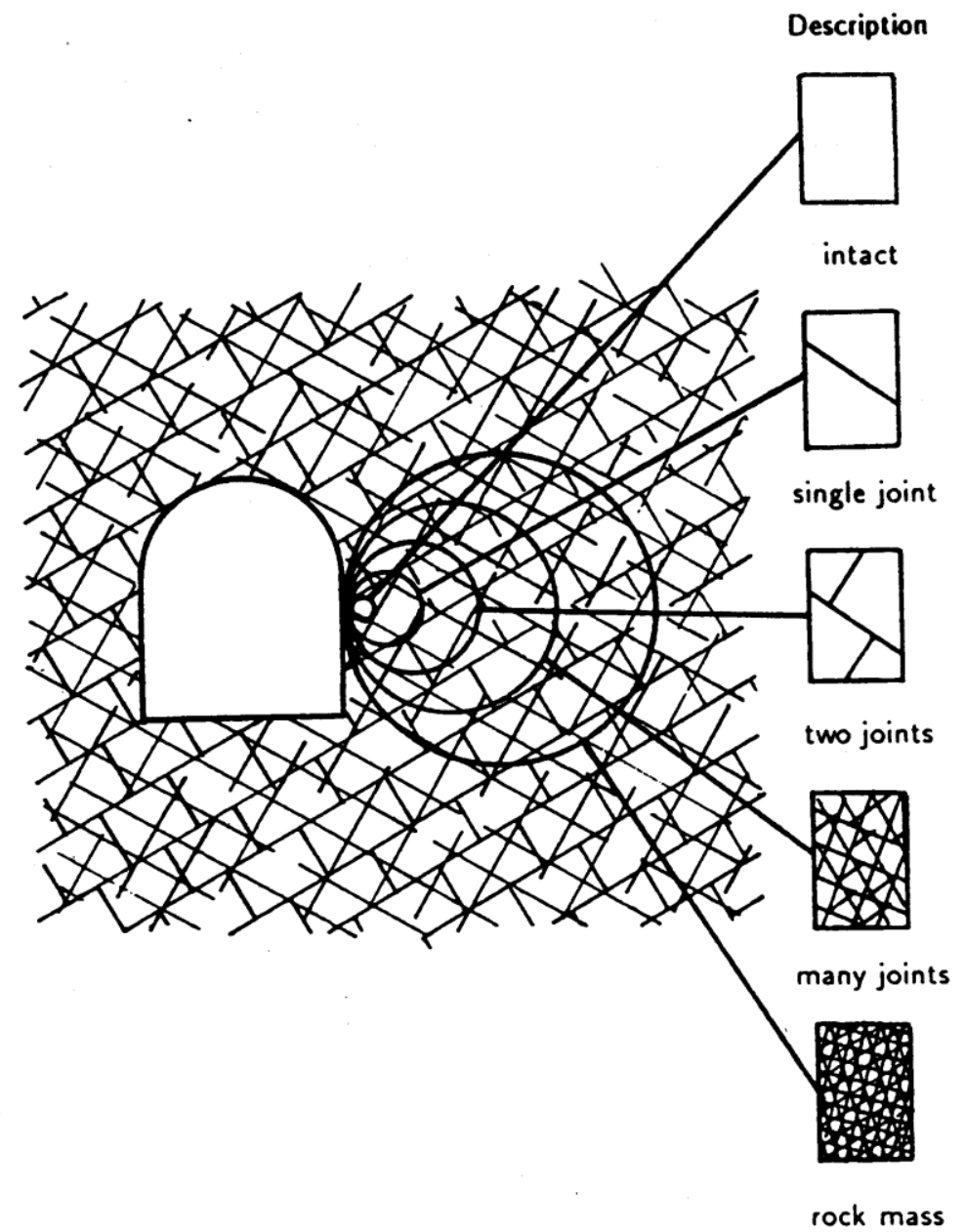

Figura 3.2 - Ilustração esquemática das diferentes escalas numa massa de rocha (Hoek \& Brown 1981). 
A descrição das descontinuidades (Figura 3.3) para caracterização do maciço deve basear-se no levantamento sistemático quantitativo dessas estruturas e na amostragem e ensaios que mostrem como elas se comportarão quando submetidas a alterações do estado de tensões in situ, ao qual estão submetidas. Para o objetivo desse trabalho, a primeira etapa basta, visto que importa a percolação natural que ocorre através dessas descontinuidades. O método adotado é o mundialmente utilizado, proposto pela ISRM (1978/2007), para descrição de descontinuidades de maciços rochosos, como será descrito a seguir.

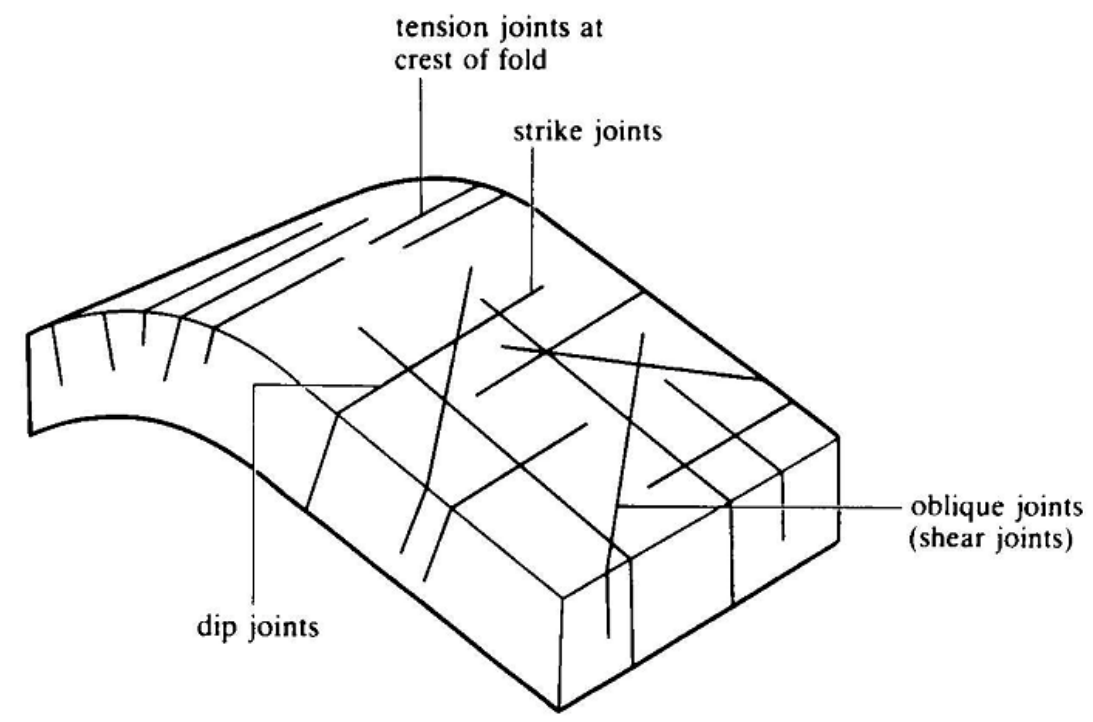

Figura 3.3 - Exemplos de diversos tipos de descontinuidades (Hoek \& Brown 1980).

Os parâmetros determinados na caracterização das descontinuidades, segundo o método da ISRM (1978), foram: orientação espacial, persistência (tamanho), espaçamento (frequência), rugosidade (geometria da superfície), abertura e preenchimento. Segundo este método, ao longo de uma scanline (referência métrica de base para posicionamento das estruturas mapeadas) todos esses parâmetros são descritos, tal como na Figura 3.4 (foto da scanline).

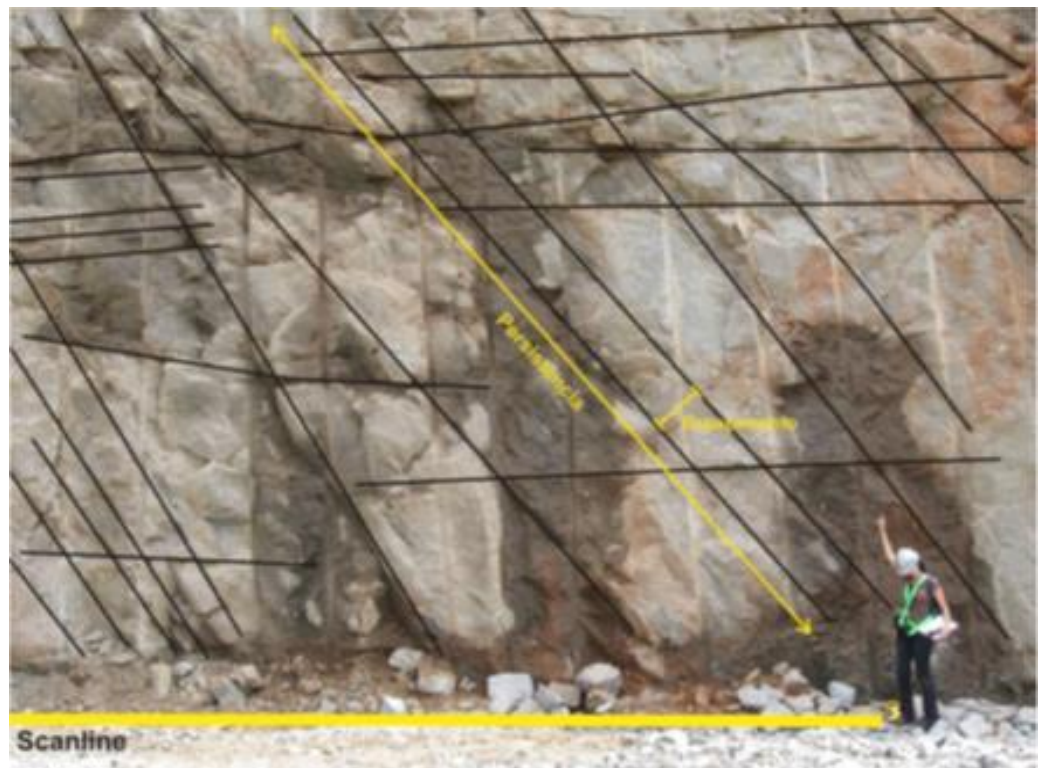

Figura 3.4 - Scanline representando exemplo de escala de observação do levantamento realizado. 


\subsubsection{Orientação}

A posição ocupada no espaço por uma estrutura geológica planar pode ser definida pela sua direção e mergulho ( $\alpha$ ), ou pela sua direção de mergulho $(\alpha)$ e mergulho ( $\beta$ ) (Figura 3.5).

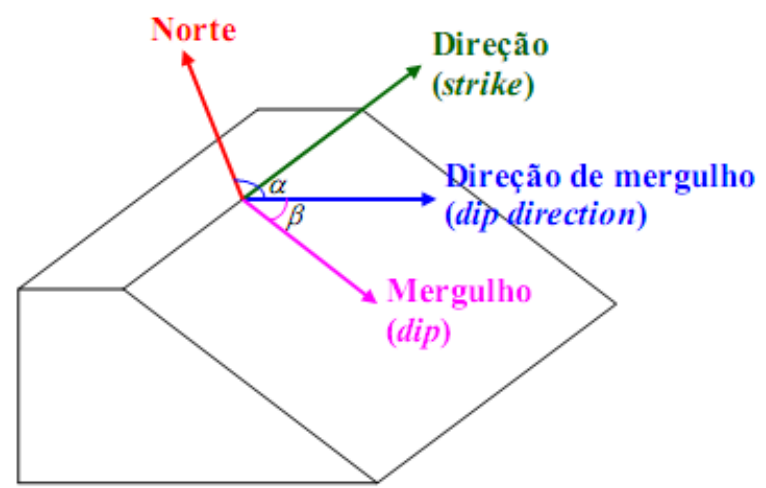

Figura 3.5 - Distribuição de feições diagnósticas ao longo do plano de descontinuidade (Hoek \& Brown 1980).

Os dados levantados em campo são úteis para a elaboração de estereogramas utilizando programas comerciais como o Dips ou o Stereonet e posterior análise da distribuição das estruturas no espaço, obtendo-se as direções mais importantes e, por conseguinte, a orientação preferencial do fluxo de água através das descontinuidades. Através de projeções estereográficas as distintas famílias de estruturas foram separadas, com vistas a possibilitar uma análise individualizada, para cada caso.

\subsubsection{Persistência}

É a extensão em área (ou dimensão) da descontinuidade, e estimada pelo comprimento dos traços das juntas nas faces dos maciços rochosos. A classificação adotada será a proposta pela ISRM (2007), sendo atribuída conforme Tabela 3.1.

\begin{tabular}{lc}
\hline Grau da Persistência & Comprimento da descontinuidade $(\mathbf{m})$ \\
\hline Muito baixa & $<1$ \\
Baixa & $1-3$ \\
Média & $3-10$ \\
Alta & $10-20$ \\
Muito alta & $>20$ \\
\hline
\end{tabular}

Tabela 3.1 - Classificação da persistência das descontinuidades segundo ISRM, 2007.

\subsubsection{Espaçamento}

O espaçamento é a distância entre duas fraturas medida ao longo de uma linha com localização e orientação específicas. Podem-se considerar três diferentes tipos de espaçamentos: espaçamento total, espaçamento de uma família de fraturas e espaçamento ao longo da normal da família de fraturas. 
O espaçamento total corresponde ao espaçamento entre duas fraturas imediatamente adjacentes, medida ao longo de uma linha com orientação e localização específicas. O espaçamento de uma família de fraturas corresponde ao espaçamento entre duas fraturas adjacentes de uma família de fraturas, medida ao longo de uma linha com orientação e localização específicas. O espaçamento ao longo da normal da família de fraturas corresponde ao espaçamento entre duas fraturas adjacentes de uma família de fraturas, medida ao longo de uma linha paralela à média da normal daquela família. A classificação segundo ISRM é descrita na Tabela 3.2.

\begin{tabular}{cc}
\hline Descrição do Espaçamento & Espaçamento (mm) \\
\hline Extremamente pouco espaçada & $<20$ \\
Muito pouco espaçada & $20-60$ \\
Pouco espaçada & $60-200$ \\
Moderadamente espaçada & $200-600$ \\
Espaçada & $600-2000$ \\
Muito espaçada & $2000-6000$ \\
Extremamente espaçada & $>6000$ \\
\hline
\end{tabular}

Tabela 3.2 - Classificação do espaçamento entre as descontinuidades segundo ISRM, 2007.

Em levantamento de campo, em geral é adotado o espaçamento ao longo da normal da família de fraturas, medindo-se a distância real entre fraturas subsequentes de mesma família, ao longo dos perfis/scanlines.

\subsubsection{Abertura}

A abertura da descontinuidade é a distância perpendicular entre paredes adjacentes de uma mesma descontinuidade. Este espaço pode estar preenchido por água ou por ar. Será adotada a classificação do ISRM, conforme Tabela 3.3. As medidas podem ser tomadas com o auxílio de fita métrica, graduada em centímetros com subdivisão até o milímetro ou com paquímetros.

\subsubsection{Preenchimento}

É o material que ocupa o espaço entre as paredes adjacentes de uma descontinuidade. É comumente menos resistente que o material da matriz rochosa. Pode ser fruto da alteração da própria rocha pela passagem de fluídos (argilominerais), ou ser composto por material transportado e precipitado na abertura da descontinuidade (exemplo dos sais e hidróxidos) ou ainda por fases minerais secundárias devido a efeitos hidrotermais ou tardi-magmáticos. Está diretamente relacionado à resistência ao cisalhamento, a deformabilidade e permeabilidade das descontinuidades. 


\begin{tabular}{|lll|}
\hline \multicolumn{1}{l}{ ABERTURA } & DESCRIÇÃO & GRUPO \\
\hline$<0,1 \mathrm{~mm}$ & Muito estreita & \\
$0,1-0,25 \mathrm{~mm}$ & Estreita & Feições fechadas \\
$0,25-0,5 \mathrm{~mm}$ & Parcialmente estreita & \\
\hline $0,5-2,5 \mathrm{~mm}$ & Aberta & \\
$2,5-10 \mathrm{~mm}$ & Moderadamente aberta & Feições entreabertas \\
$>10 \mathrm{~mm}$ & Larga & \\
\hline $1-10 \mathrm{~cm}$ & Muito larga & \\
$10-100 \mathrm{~cm}$ & Extremamente larga & Feições abertas \\
$>1 \mathrm{~m}$ & Cavernosa & \\
\hline
\end{tabular}

Tabela 3.3 - Classificação dos tipos de abertura entre descontinuidades segundo ISRM, 2007.

\subsubsection{Rugosidade}

É caracterizada por ondulações na superfície da descontinuidade. As medidas podem ser feitas através de perfis lineares destas estruturas, determinando-se com o auxílio de pente de aço ou rugosímetro a rugosidade de sua superfície. No mapeamento de campo, entretanto, as medidas de rugosidade são de forma geral obtidas por comparação com os perfis típicos, apresentados na Figura 3.6.

Como resultado desse levantamento, outras características podem ser determinadas, tais como:

\subsubsection{Percolação}

Fluxo de água e umidade livre, visíveis em descontinuidades individuais ou no maciço rochoso como um todo (Figura 3.7).

A percolação de água no maciço rochoso resulta principalmente do fluxo através de descontinuidades.

Figura 3.6 - Ocorrência de água associada a presença de descontinuidades no maciço rochoso evidenciada pela coloração mais escura na frente de lavra. 


\subsubsection{Número de Famílias}

É a quantidade de famílias que compõem um sistema de juntas. O maciço rochoso pode conter também descontinuidades individuais. Essas famílias foram diferenciadas, a partir das projeções estereográficas.

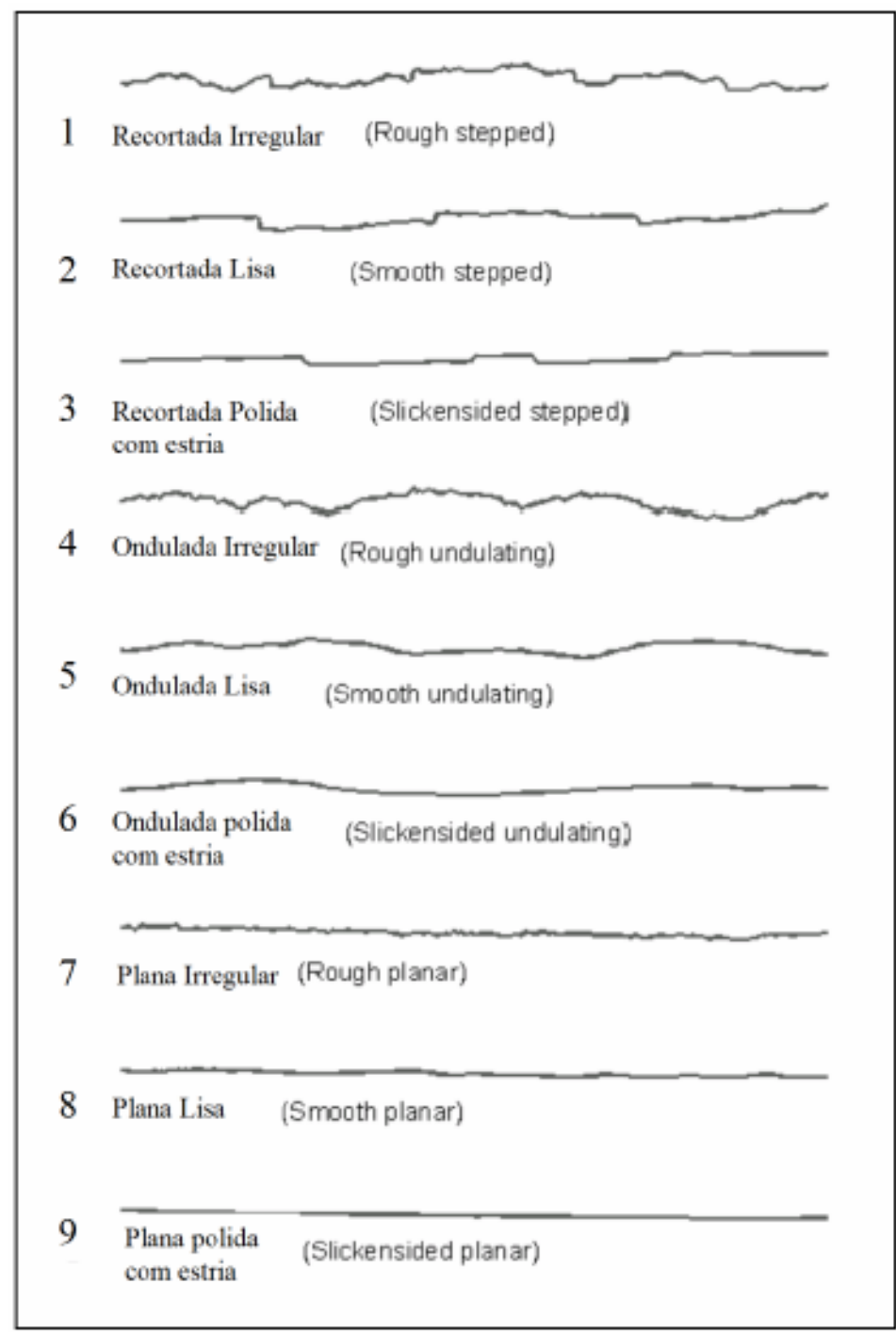

Figura 3.6 -Classificação da rugosidade da superfície das estruturas não preenchidas, de acordo com ISRM (1978).

\subsubsection{Tamanho de Blocos}

São as dimensões dos blocos de rocha que resultam da orientação das famílias de juntas que se interceptam e do espaçamento das famílias individuais. Descontinuidades individuais podem influenciar o tamanho e a forma dos blocos.

Dentre os parâmetros analisados, alguns são determinantes, no que se refere às propriedades hidráulicas do aquífero. Já outros estão diretamente relacionados com a determinação de fluxo. Sendo assim temos que:

- Propriedades Hidráulicas associadas à caracterização física dos maciços, incluindo porosidade, condutividade hidráulica e transmissividade. 
Em relação a porosidade, nota-se que a abertura, o preenchimento e a rugosidade das descontinuidades são as propriedades mais relevantes. No que se refere a porosidade, condutividade hidráulica e transmissividade, somam-se a esses parâmetros a persistência e o espaçamento que, quanto maiores, aumentam as chances de conectividade entre as estruturas.

- Propriedades de Fluxo vinculadas à caracterização dinâmica incluindo direção das linhas de fluxo e escoamento em meios fraturados.

A determinação da direção do fluxo de água subterrânea depende da atitude das descontinuidades, aliada a sua persistência e espaçamento. Para o escoamento acrescenta-se a abertura e seu preenchimento.

Para a determinação da abrangência do modelo conceitual proposto, além do levantamento sistemático dos dados, considerou-se o mapeamento estrutural realizado pela INB e levantamento de estruturas aleatório, dentro das cavas das minas e no contexto regional das áreas visitadas (Figura 3.8). Destaca-se que esses dados adicionais não se aplicam a caracterização do maciço, posto que sua obtenção não seguiu uma metodologia sistemática, de acordo com sua distribuição na massa de rocha. Entretanto pode-se ampliar a partir destas estruturas a ampliação da natureza do modelo do aquífero para as áreas circunvizinhas visitadas, e de forma mais ampla, para locais de natureza similar (rochas graníticas e gnáissicas, sob mesmo regime tectônico e mesmo clima).

\subsection{Resultados}

No levantamento sistemático das descontinuidades obteve-se 623 estruturas, distribuídas ao longo das bancadas, até a profundidade de 100 metros.Dados mais recentes, considerando o aprofundamento das cavas, cuja bancada mais profunda alcança os 150 metros, referem-se ao mapeamento estrutural executado pela INB, que compreende 135 medidas. Além deste conjunto, na última campanha de campo realizada em março de 2014, foram obtidos mais 379 dados de descontinuidades, totalizando 1.137 estruturas, cujas atitudes foram medidas e projetadas, para avaliar as características do sistema aquífero analisado.

A aquisição dos dados no âmbito da construção das scanlines balizou-se na determinação de um sistema de coordenadas local, tomando como origem $(0,0)$ no início de cada bancada (Figura 3.9, início do primeiro perfil), onde o X representa a distância horizontal, em relação a origem do perfil, e o Y representa o comprimento das estruturas. Para aquelas estruturas cujo comprimento do traço mapeável no afloramento, se dá na horizontal, tem sua persistência refletida no eixo x.As scanlines foram construídas de modo a representar o comportamento das descontinuidades, ao longo da profundidade do maciço rochoso. Na época deste levantamento, a mina mais profunda atingia 100 metros de exposição de rochas. 


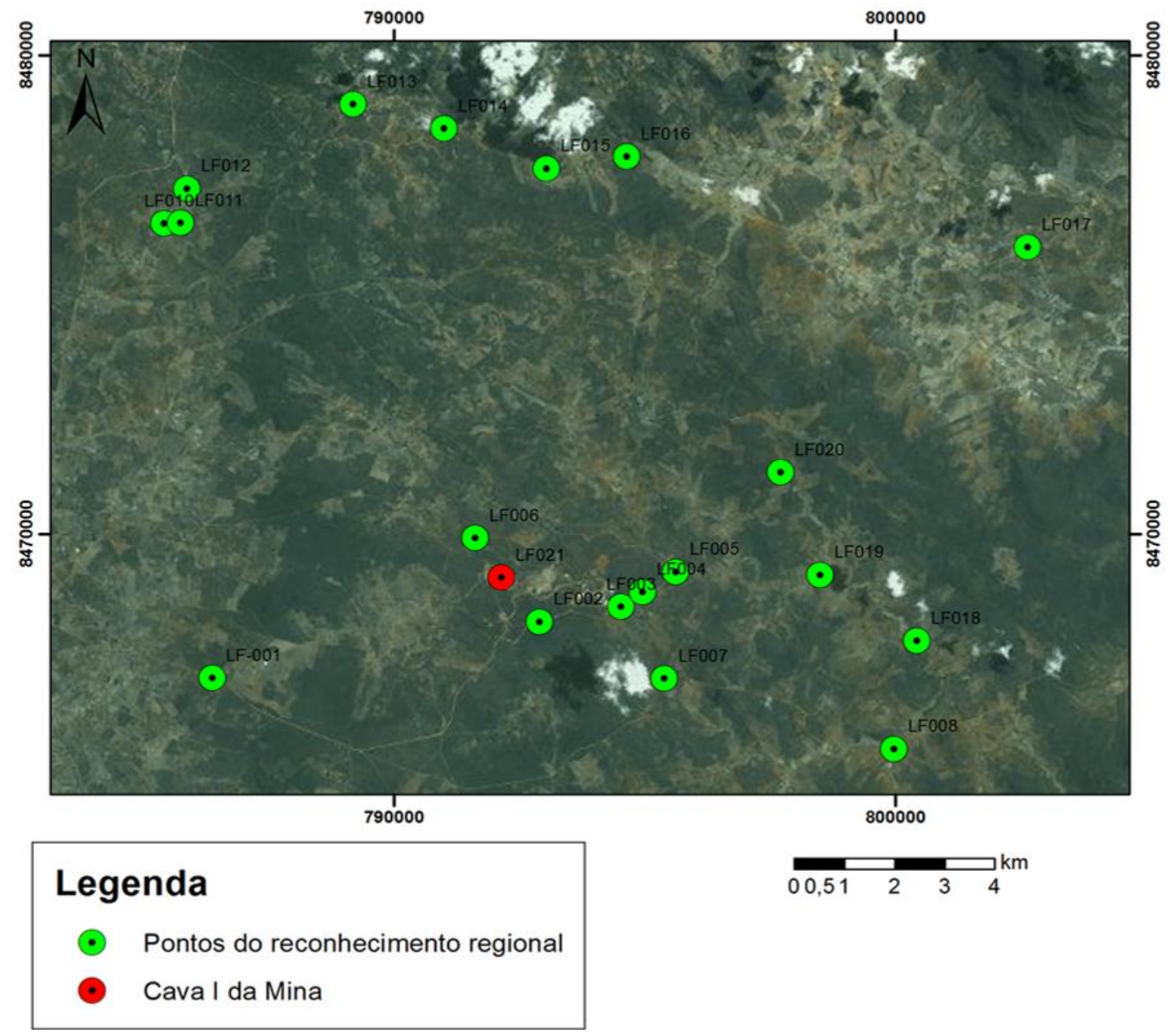

Figura 3.8 - Localização dos pontos visitados na atividade de campo realizada em março de 2014.

É importante ressaltar que as cavas foram construídas visando gerar a menor relação de estéril-minério possível. Nesse sentido, foram produzidos taludes quase verticais, bem como bancadas estreitas. Soma-se a isso a instabilidade gerada em determinadas áreas da cava, onde a direção do caimento dos taludes coincidia com a direção das descontinuidades e orientação dos gnaisses, provocando o deslizamento de blocos. Tendo em vista este empecilho, a construção dos perfis ficou condicionada as regiões onde a equipe de controle e segurança da mina considerou seguro caminhar. Como resultado, as cotas levantadas foram: primeira scanline em 890 metros, segunda em 830 metros e terceira na cota de 800 metros (lembrando que o eixo $x$ coincide com a cota). Sendo assim, o primeiro foi denominado intervalo superior, o segundo intervalo intermediário e o terceiro, intervalo inferior. 


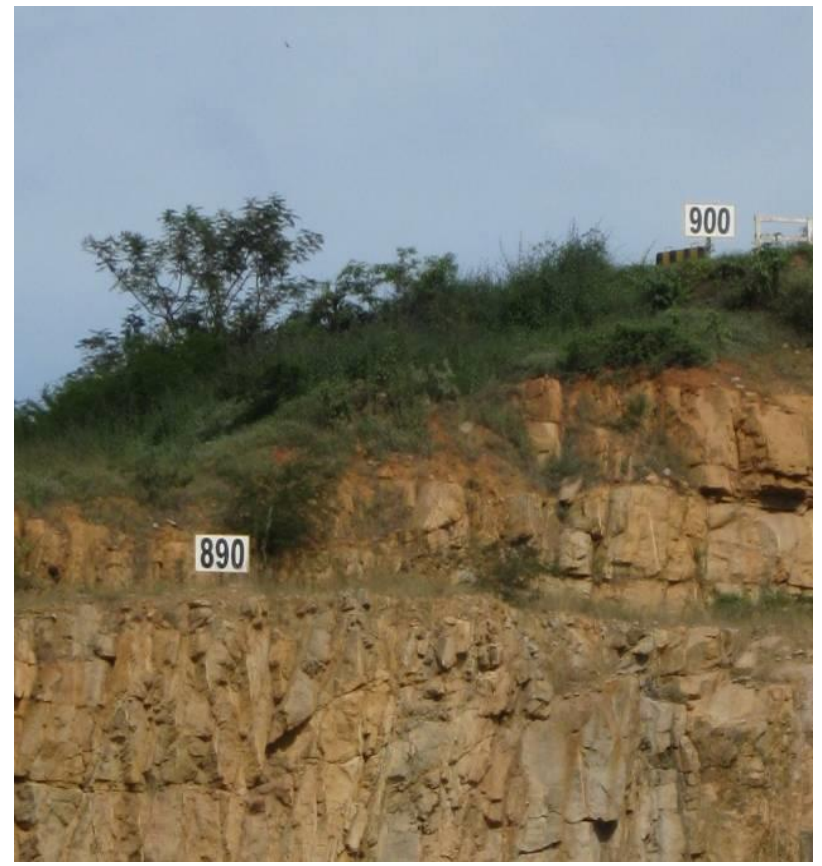

Figura 3.9 - Início da primeira scanline (mapeamento realizado nas áreas de mineração da URA).

\subsubsection{Estereogramas e Análise de Fluxo}

As projeções estereográficas das descontinuidades (Figuras 3.10 e 3.11), a partir dos dados obtidos no levantamento sistemático, indicam a presença de três famílias de estruturas dominantes. A primeira família mergulha na direção NE, a segunda tem caimento para a direção W (SW-W-NW), e a terceira (FA-SH) corresponde a descontinuidades sub-horizontais. Nota-se, ainda que existem em concentração muito baixa algumas estruturas com caimento para $\mathrm{E}$.

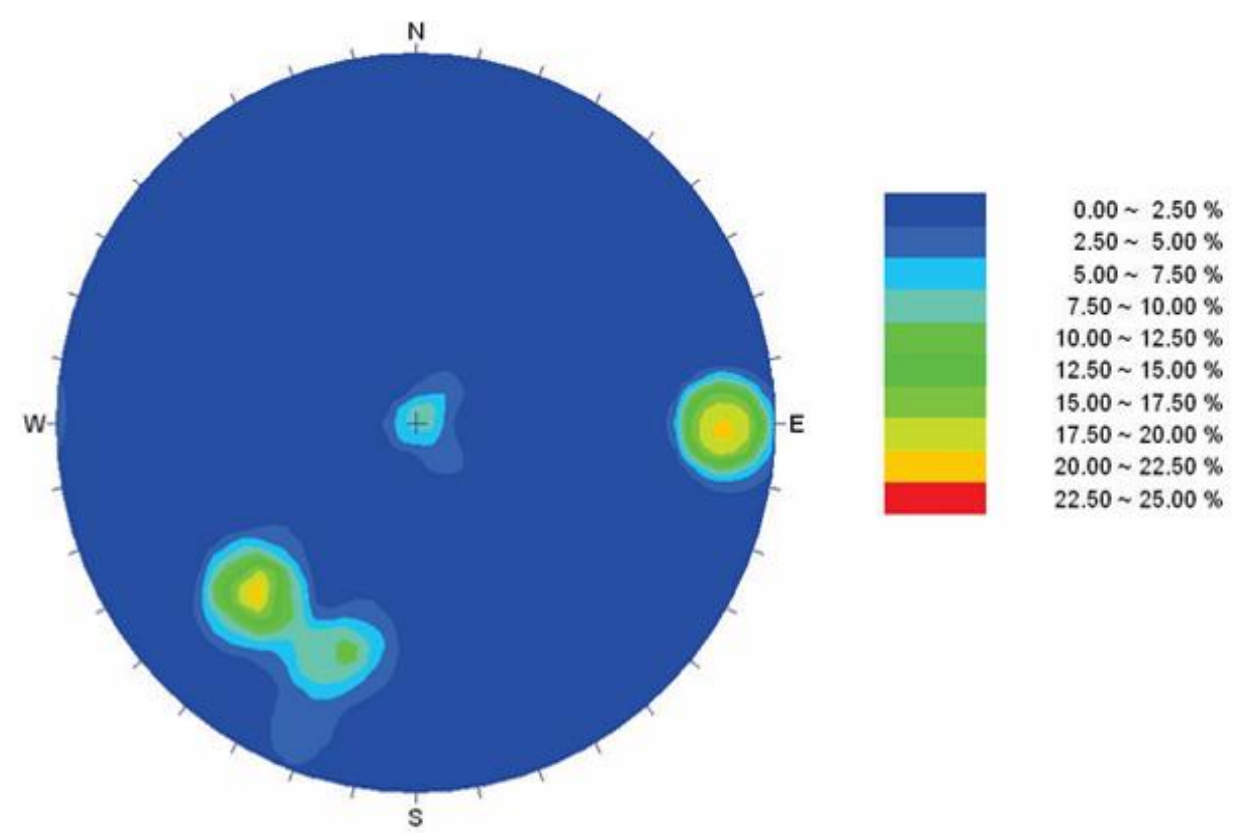

Figura 3.10 - Contorno dos polos obtidos da projeção de 623 polos, a partir do levantamento sistemático das estruturas. 


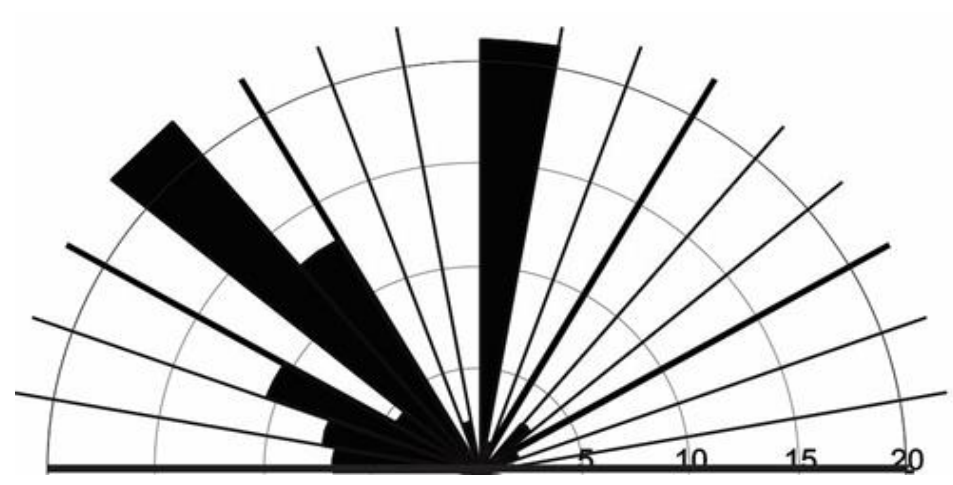

Figura 3.11 - Strikes das descontinuidades, obtidos a partir da projeção dos dados, obtidos no levantamento sistemático.

De acordo com a Figura 3.12, em conformidade com o levantamento sistemático, a FANE, FA- SW-W-NW e FA-SH correspondem respectivamente a $51,3 \%, 21,5 \%$ e $20,2 \%$ do total de descontinuidades identificadas.

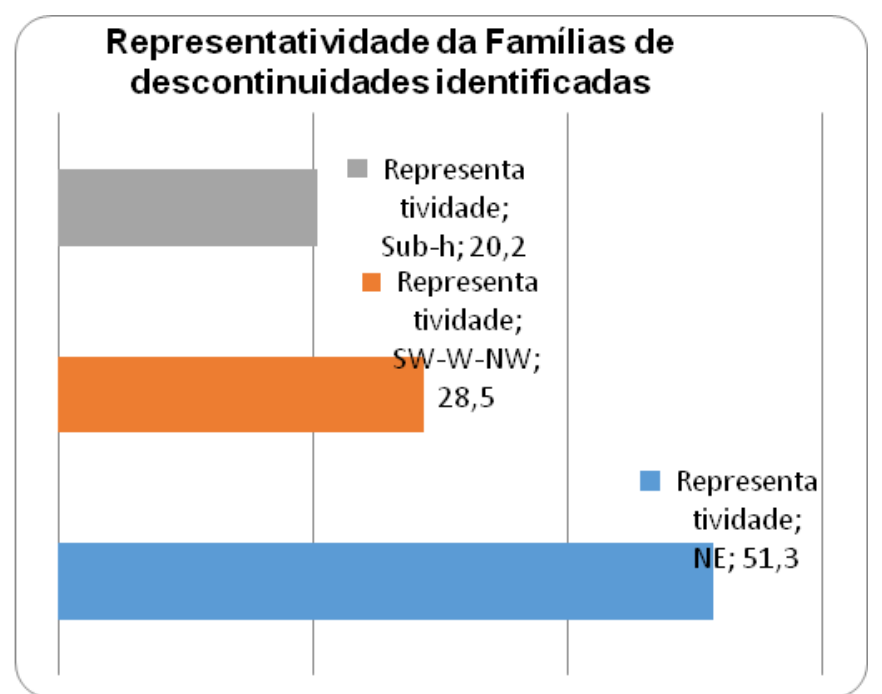

Figura 3.12 - Representatividade (em porcentagem) das Famílias de descontinuidades identificadas, a partir do levantamento sistemático das anisotropias do maciço.

\subsubsection{Família de Descontinuidades com Mergulho para NE}

Esta família de estruturas (Figuras 3.13 e 3.14) mergulha na mesma direção da foliação (Sx) dos gnaisses presentes na área, cujas medidas observadas em campo foram, aproximadamente, $020^{\circ} / 55^{\circ}$ (todas as medidas obtidas na notação dip/dip), podendo haver variações locais de $055^{\circ} / 65^{\circ}, 090^{\circ} / 70^{\circ}$ e $070^{\circ} / 68^{\circ}$. Dentre as descontinuidades encontradas nesse grupo, ressalta-se a ocorrência de falhas bastante penetrativas na massa de rochas, cujos mergulhos predominam entre $045^{\circ} / 70^{\circ}$ e $055 / 70^{\circ}$, com variações de $030^{\circ} / 70^{\circ}$, $015 / 60^{\circ}$, 050은 Estas estruturas apresentam persistência muito alta, de acordo com ISRM (1981), com valores que ultrapassam os 40 metros. Normalmente estas falhas não estão preenchidas e suas aberturas variam de $1 \mathrm{~mm}$ a $3 \mathrm{~mm}$, classificadas como abertas a moderadamente abertas. 


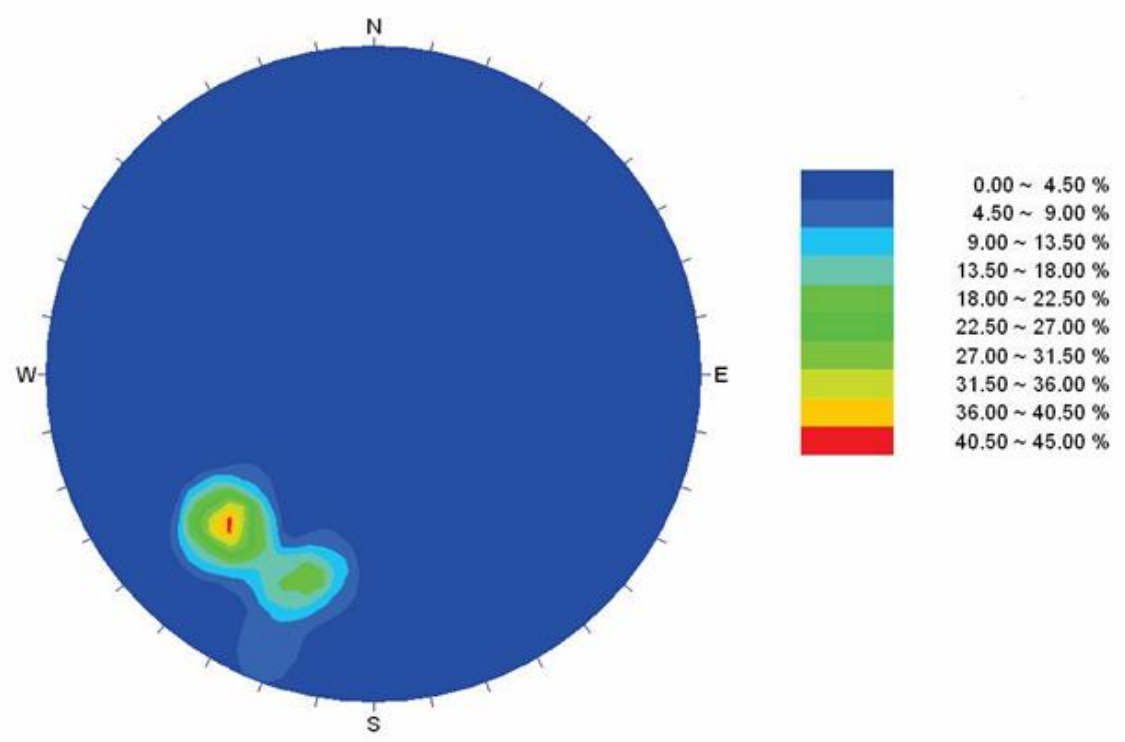

Figura 3.13 - Contorno dos polos obtidos da projeção de 318 medidas, referentes à família de descontinuidades com mergulho para NE.

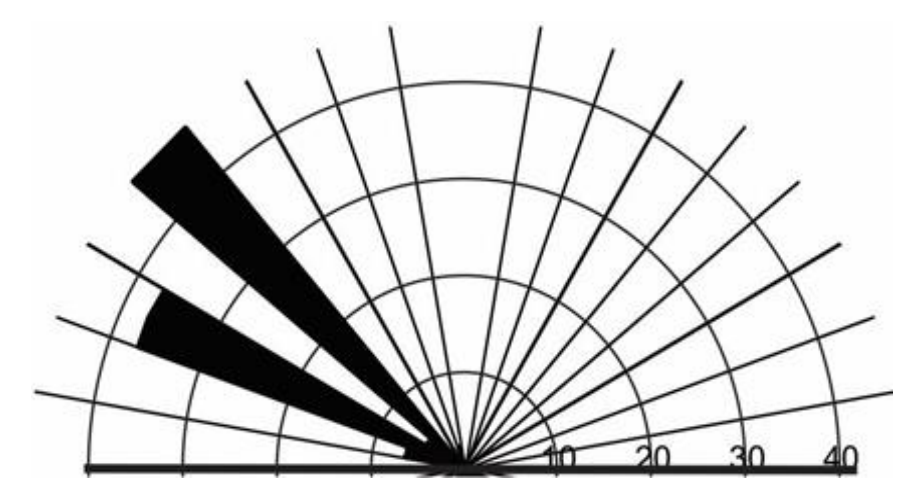

Figura 3.14 - Projeção dos strikes referentes à família de descontinuidades com mergulho para NE.

Ainda observam-se zonas de cisalhamento com mergulho $070^{\circ} / 71^{\circ}$, $042^{\circ} / 64^{\circ}$ e $040^{\circ} / 59^{\circ}$. Nessas zonas há migração de minerais máficos (principalmente biotita), que se apresentam, em grande parte da área, alterados pela presença de água, formando preenchimento argiloso. Se por um lado, nessas áreas a frequência grande de descontinuidades (espaçamentos de poucos centímetros) favorece a percolação de água, por outro, o preenchimento por material argiloso dificulta o fluxo.

\subsubsection{Família de Descontinuidades com Mergulho para SW-W-NW}

O segundo grupo de anisotropias mais importante tem mergulho predominante para $W$ $\left(270^{\circ}\right)$. Com a ampliação da profundidade (chegando a cota de $860 \mathrm{~m}$ ) estas estruturas diminuem a frequência. A sua persistência preponderante está nas classes média e baixa, indicando que têm entre 1 e 10 metros.

No talude SE onde o levantamento foi iniciado, nas cotas $900 \mathrm{~m}$ a $860 \mathrm{~m}$ o maciço encontra-se bastante fraturado. Com 0 aumento da profundidade, prevalecem as descontinuidades para NE. 
Ressalta-se que as estruturas mais penetrativas dessa família (com persistência superior a 40 metros), correspondem a zonas de cisalhamento, subverticais, com strike Norte/Sul e mergulho para W $\left(270^{\circ} / 80^{\circ}\right)$. Essas estruturas equivalem a cerca de $17 \%$ do total desta família.

Optou-se por englobar numa mesma família as estruturas para W, SW e NW (Figuras 3.15 e 3.16) pela avaliação das projeções estereográficas, onde as descontinuidades com mergulho para $\mathrm{W}$ predominam sobre as demais, entretanto, apresentam características bastante semelhantes.

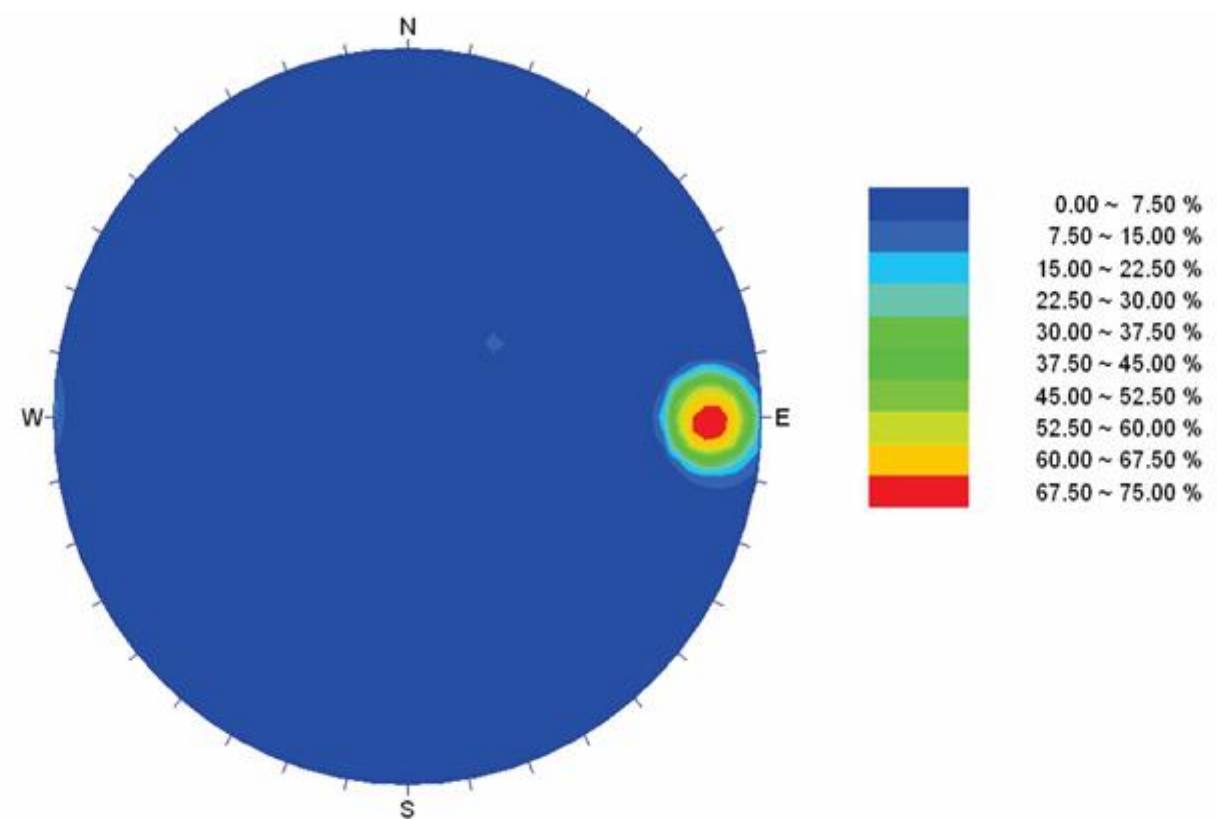

Figura 3.15 - Contorno dos 179 polos obtidos da projeção da família de descontinuidades com mergulho para SW-W-NW.

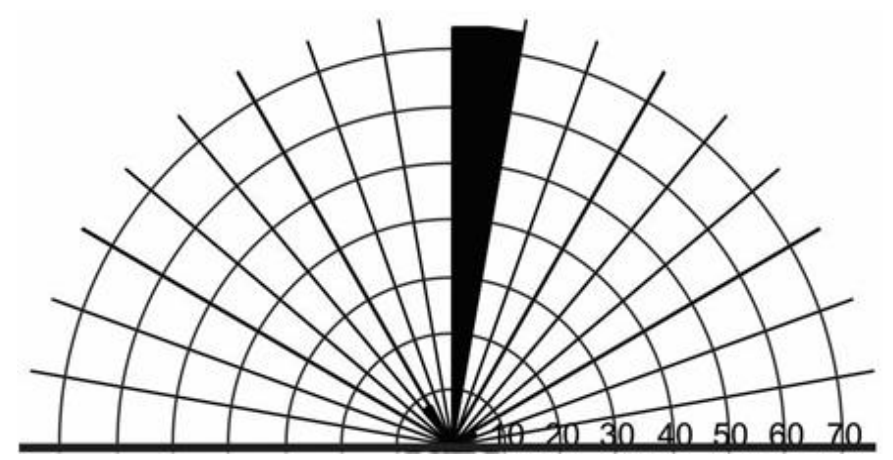

Figura 3.16 - Projeção dos strikes referentes à família de descontinuidades com mergulho para SW-WNW.

\subsubsection{Família de Descontinuidades Sub-horizontais - FA-SH}

A presença de descontinuidades sub-horizontais,associadas a falhas de empurrão de baixo ângulo ou alívio do estado de tensões do maciço, resulta em valores significativamente maiores de condutividade hidráulica horizontal.Apesar das condutividades hidráulicas mais elevadas serem comuns a algumas estruturas, o armazenamento e comportamento do aquífero,em longo prazo,rege-se pela densidade e conectividade dessa rede de descontinuidades. 
No estudo do sistema fraturado, as juntas de alívio e falhas sub-horizontais (como foram chamadas), são as descontinuidades mais relevantes para a interconexão do aquífero. Estas estruturas têm atitudes abrangendo todos os quadrantes do sistema de projeção, destacando- se as famílias que mergulham em baixo ângulo para NW e SW $\left(314^{\circ} / 16^{\circ}\right.$ e $\left.220^{\circ} / 20^{\circ}\right)$ e as completamente horizontais (Figura 3.17). A gênese dessas estruturas está relacionada, tanto ao alívio de carga, quanto a falhas de empurrão de baixo ângulo (Figura 3.18).

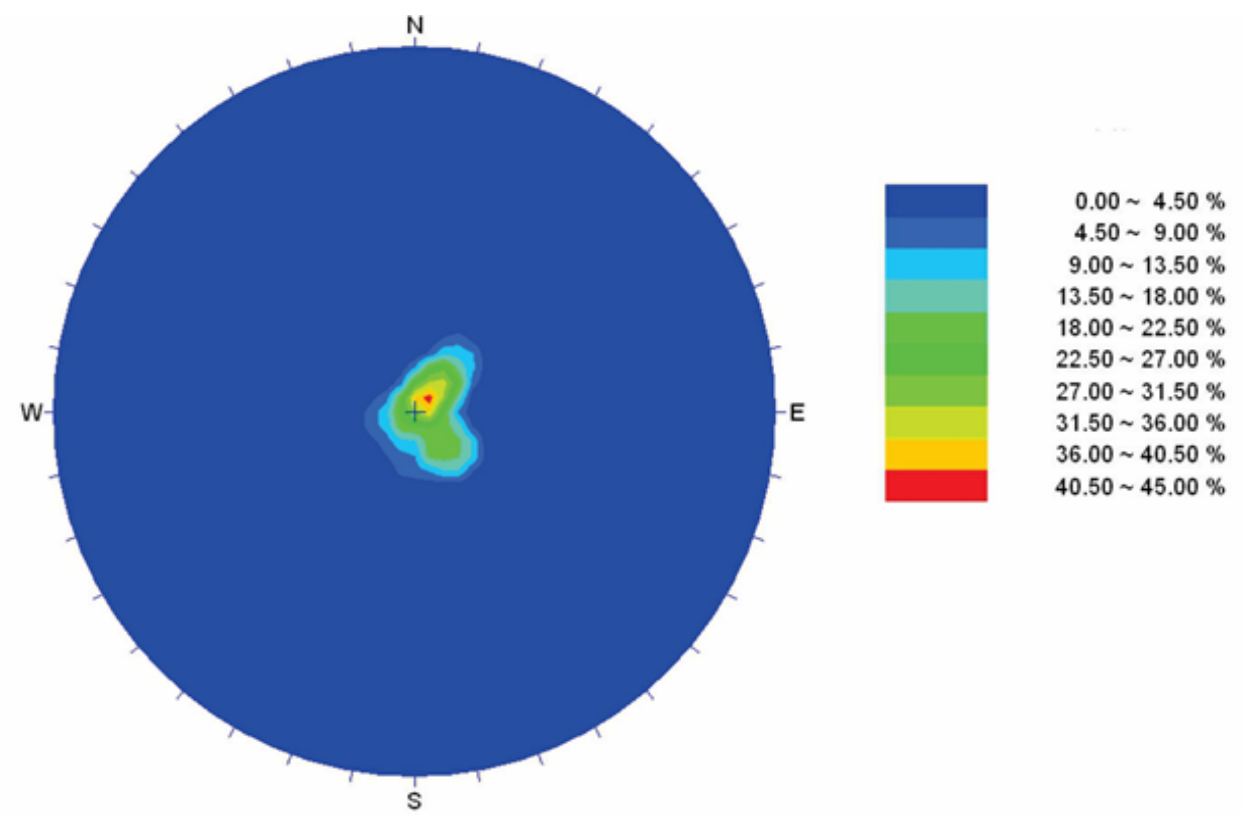

Figura 3.17 - Projeção do contorno dos 126 polos, obtidos das descontinuidades sub-horizontais.

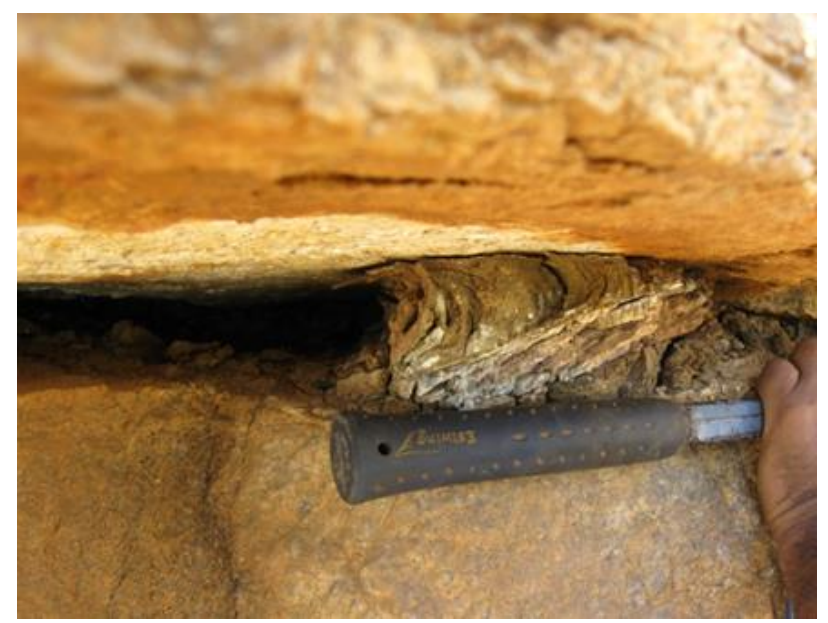

Figura 3.18 - Indício de que a estrutura sub horizontal é uma falha de empurrão de baixo ângulo (Registro realizado durante atividade de campo na área).

\subsubsection{Descrição Comparativa das Famílias de Descontinuidades}

Dentre as famílias individualizadas, a Família NE (Figura 3.19) destaca-se por apresentar persistência muito alta, em mais de $60 \%$ do total, assim como os menores espaçamentos. Isso implica em descontinuidades muito penetrativas e com frequência alta. Considerando também que a distribuição das aberturas, mesmo com $72 \%$ concentrando-se na classe "aberta", são 
distribuídas por todos os intervalos. Esses atributos favorecem a percolação de fluxo através dessas anisotropias. A exceção das zonas de cisalhamento supracitadas, essa família exerce papel fundamental na recarga do aquífero, propiciando a infiltração de água até grandes profundidades, dentro deste sistema estudado.

No caso da família SW-W-NW (Figura 3.20), suas persistências apresentam-se mais constantes nas classes média e baixa ( $41 \%$ e $33 \%$ respectivamente), entretanto, distribuem-se, mesmo que com menor representatividade, em todas as demais classes. Com estruturas principalmente abertas e espaçamentos variando de muito pouco espaçados, a espaçados. A recarga através dessa família está condicionada a interceptação com outras estruturas quepropiciem a formação de uma rede interconectada. Ressalta-se que, cerca de $17 \%$ dessas anisotropias tem persistência muito alta, e estão associadas a zonas de cisalhamento.

Por fim, como grande responsável pela conectividade desse sistema aquífero tem-se as descontinuidades sub-horizontais (Figura 3.21). Essas estruturas são fundamentais ao fluxo e armazenamento de água subterrânea, na área de estudo. Estendendo-se por todo o maciço da cava da mina, que atualmente encontra-se com 150 metros de profundidade. Apresentam espaçamento e persistência com distribuição mais uniforme, em comparação com as demais e suas aberturas sobressaem nas classes abertas e moderadamente largas, todavia em campo observou-se algumas estruturas cujas aberturas enquadram-se como cavernosas.

Em resumo, a parte superior do maciço (concentrando-se em torno da cota de 890 metros) é bastante fraturada, apresentando estruturas menos persistentes, com pouco espaçamento entre elas. Conforme se aprofunda nas cavas observa-se aumento das estruturas com mergulho para NE. A zona de cisalhamento mais relevante tem orientação $270^{\circ} / 80^{\circ}$. Em se tratando de recarga, prevalece a família com mergulho para NE, dada sua alta persistência, apesar de menos frequentes. Zonas de falhas muito persistentes, com espaçamentos pequenos, abertas e sem preenchimento compõem parte essencial das anisotropias que favorecem a recarga, nessa última família. Finalmente, como grandes responsáveis pelo armazenamento e fluxo de água, encontram-se as descontinuidades sub-horizontais. Essas são constantes, e acham-se ao longo de toda a profundidade de afloramentos observada. 


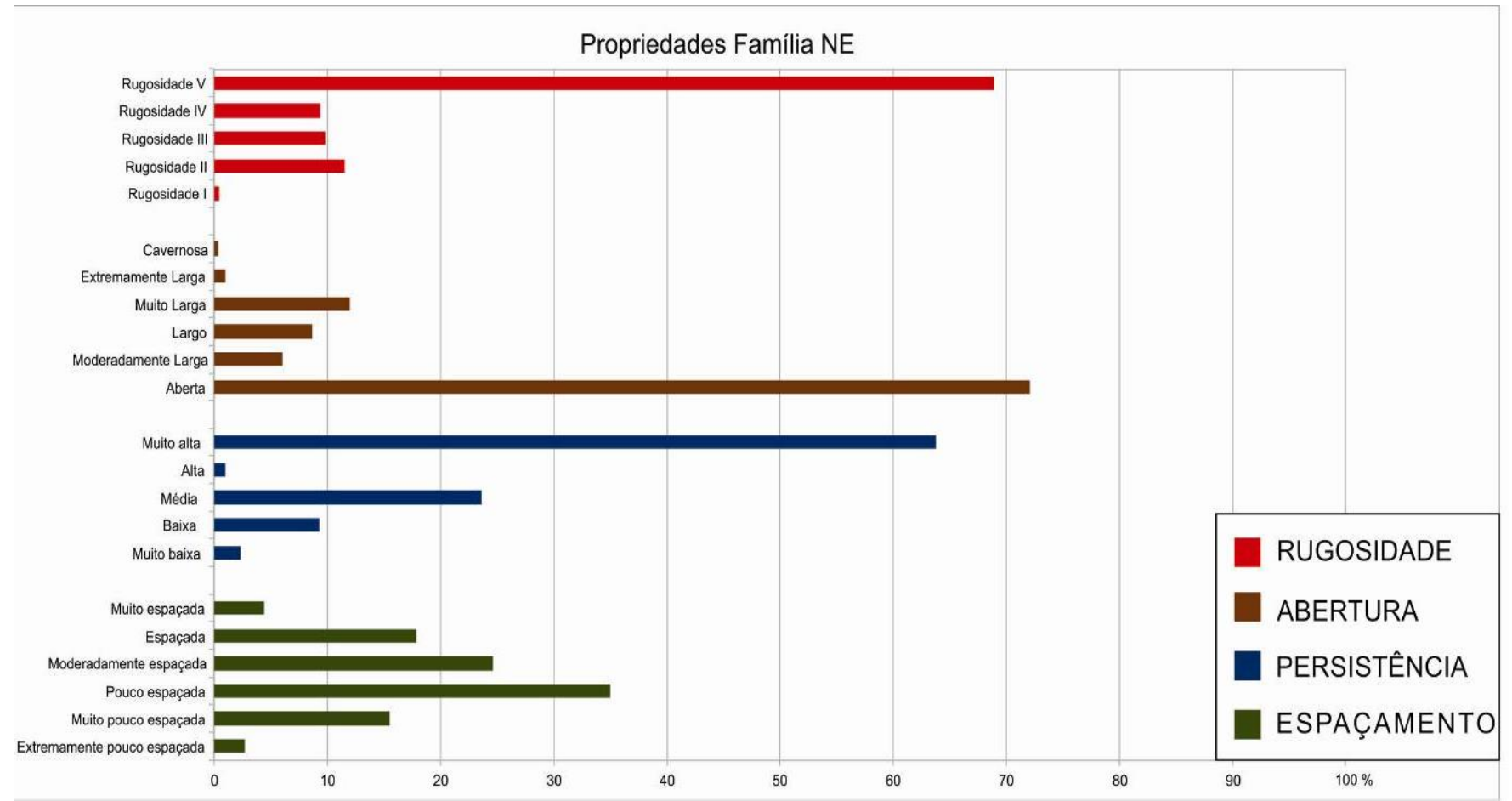

Figura 3.19 - Parâmetros diagnosticados no levantamento sistemático das descontinuidades, referente a Família NE.

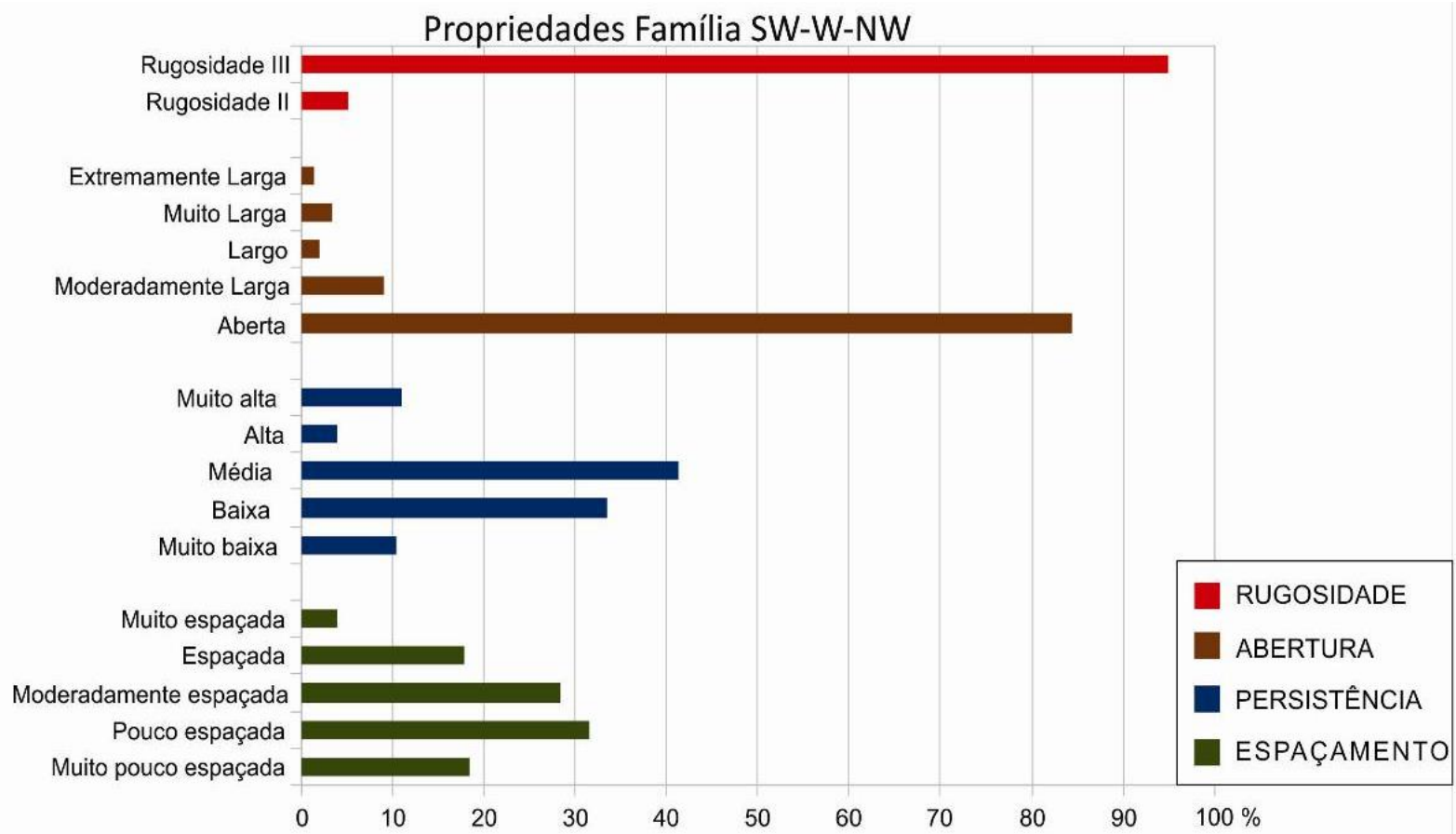

Figura 3.20 - Parâmetros diagnosticados no levantamento sistemático das descontinuidades, referente a Família SW-W-NW. 


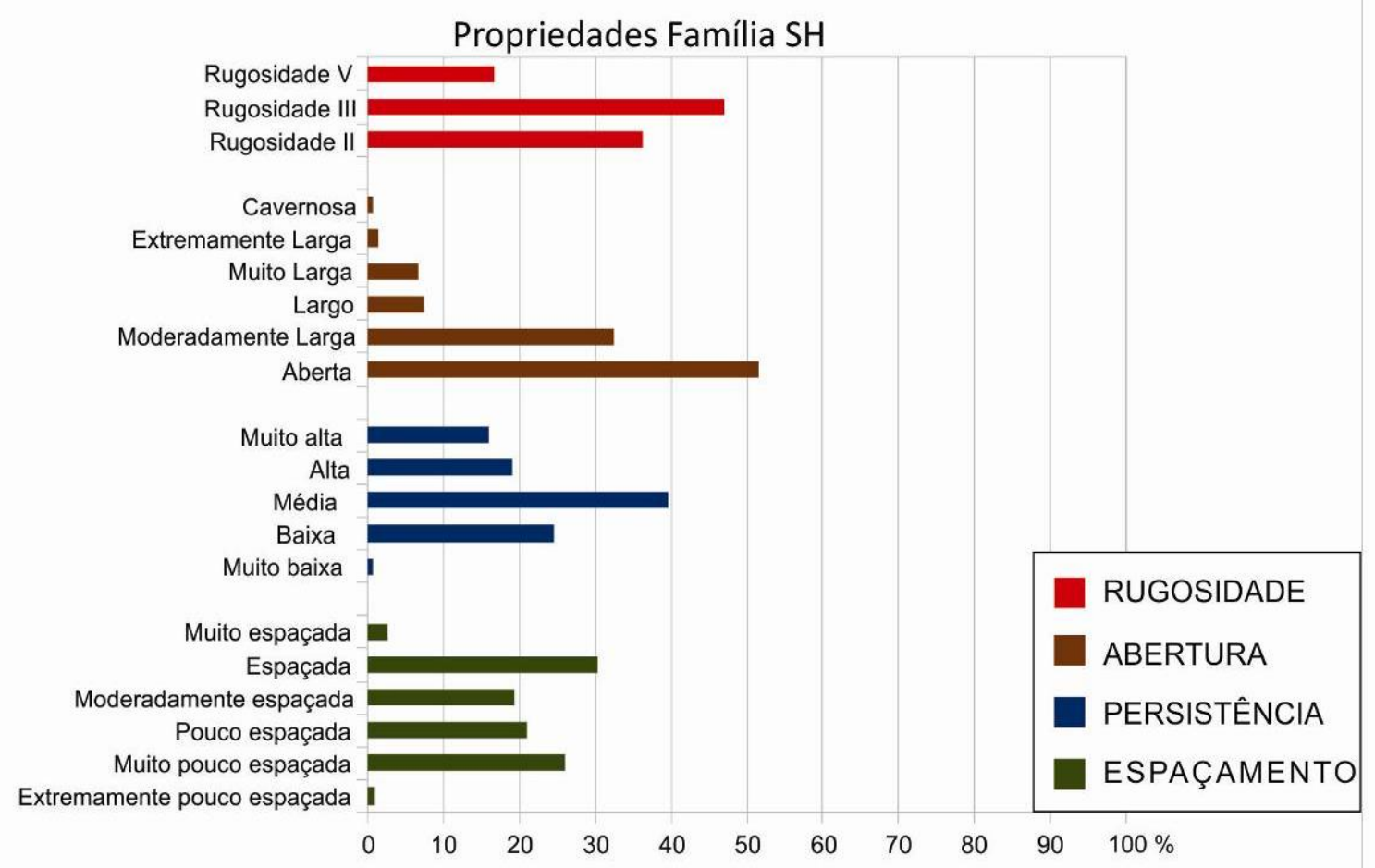

Figura 3.21 - Parâmetros diagnosticados no levantamento sistemático das descontinuidades, referente a Família Sub-horizontal.

Considerando os dados produzidos por levantamentos aleatórios, realizados tanto pela INB no final de 2012, quanto no último campo regional realizado em 2014, nas áreas das cavas (Corpo I e III) e em regiões circunvizinhas ao complexo da URA, construiu-se estereogramas para visualizar a distribuição dessas descontinuidades, como se observa na Figura 3.22.
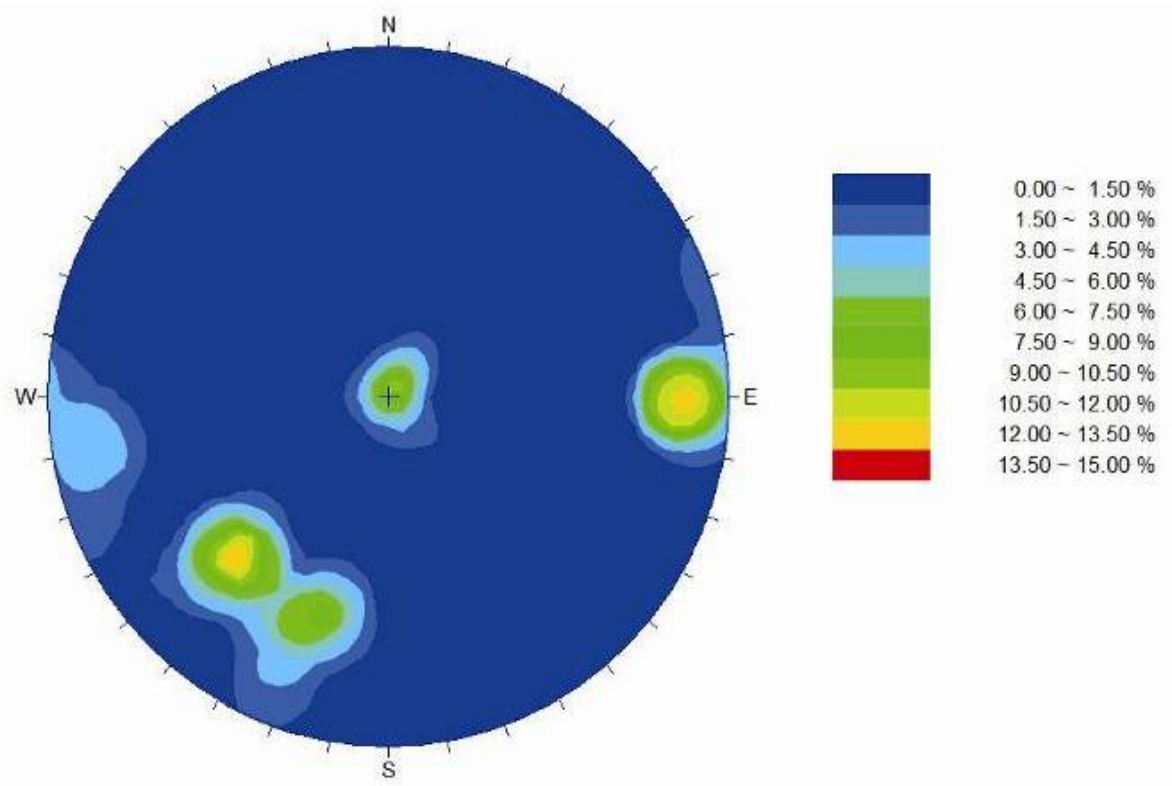

Figura 3.22 - Projeção estereográfica de todos os dados (levantamento da INB, mapeamento das áreas circunvizinhas ao Complexo, bem como levantamento sistemático das estruturas).

Observa-se que as três famílias individualizadas anteriormente persistem. Entretanto, as estruturas com mergulho aproximado para $E$ tornam-se mais claras e visíveis, visto que eram menos expressivas. As justificativas para essa diferença podem estar associadas ao caráter não 
sistemático dos levantamentos considerados, que podem representar certa tendência na eleição das estruturas obtidas nesses mapeamentos. Além disso, o levantamento realizado fora dos limites do Complexo Mínero Industrial se restringiu a afloramentos em forma de lajedos, considerando a escassez de afloramentos para serem estudados.

De modo geral, as três famílias de descontinuidades individualizadas representam as estruturas mais relevantes na área analisada, em se tratando de recarga, acumulação e existência de fluxo de água.

\subsubsection{Análise da Distribuição dos Parâmetros no Maciço}

De acordo com o descrito, o levantamento consistiu da elaboração de scanlines, ao longo da qual todos os parâmetros foram colhidos sistematicamente. Buscou-se caracterizar toda a profundidade do maciço, respeitadas as limitações de segurança. Isto se deu, em virtude do ângulo de taludamento quase vertical, para produzir a menor relação estéril/minério, o que gerou deslizamento de blocos e impossibilitou a circulação segura de pedestres em determinadas áreas. Por conseguinte, respeitando o objetivo de aplicar a metodologia ao longo da profundidade, bem como os limites de segurança impostos pela mineradora, as scanlines foram construídas nas cotas de 890, 830 e 800 metros, denominadas de compartimentação superior, intermediária e inferior, respectivamente.

Estruturas com persistência muito alta, que ultrapassaram os limites dos taludes, foram diagnosticadas considerando ainda o tamanho das bancadas sobrejacentes.

Essa compartimentação do maciço buscou determinar as variações dos parâmetros, relativos as descontinuidades, na massa de rochas. Os resultados obtidos seguem nas Figuras $3.23,36.24$ e 3.25 .

De acordo com o levantamento, o espaçamento varia de muito pouco espaçado a espaçado, ao longo de todos os intervalos de profundidade do maciço. Isso implica dizer que o espaçamento está entre 2 centímetros e 2 metros, o que denota um maciço bastante descontínuo, fragmentado.

Em se tratando de persistência, esse parâmetro apresenta a maior diversificação, conforme se aprofunda nas cavas. No trecho superior, classifica-se de muito baixa a média, associado as descontinuidades com mergulho para SW-W-NW. No intervalo intermediário encontra-se entre baixa e alta. Já na parte inferior do maciço a persistência é muito alta, principalmente por conta da família que mergulha para NE.

No que se refere a abertura, o maciço, na sua parte superior, tem descontinuidades proporcionalmente mais abertas. Esse afastamento entre as paredes das estruturas tende a diminuir, conforme aumenta a profundidade. Esse fator favorece a recarga do sistema aquífero. 


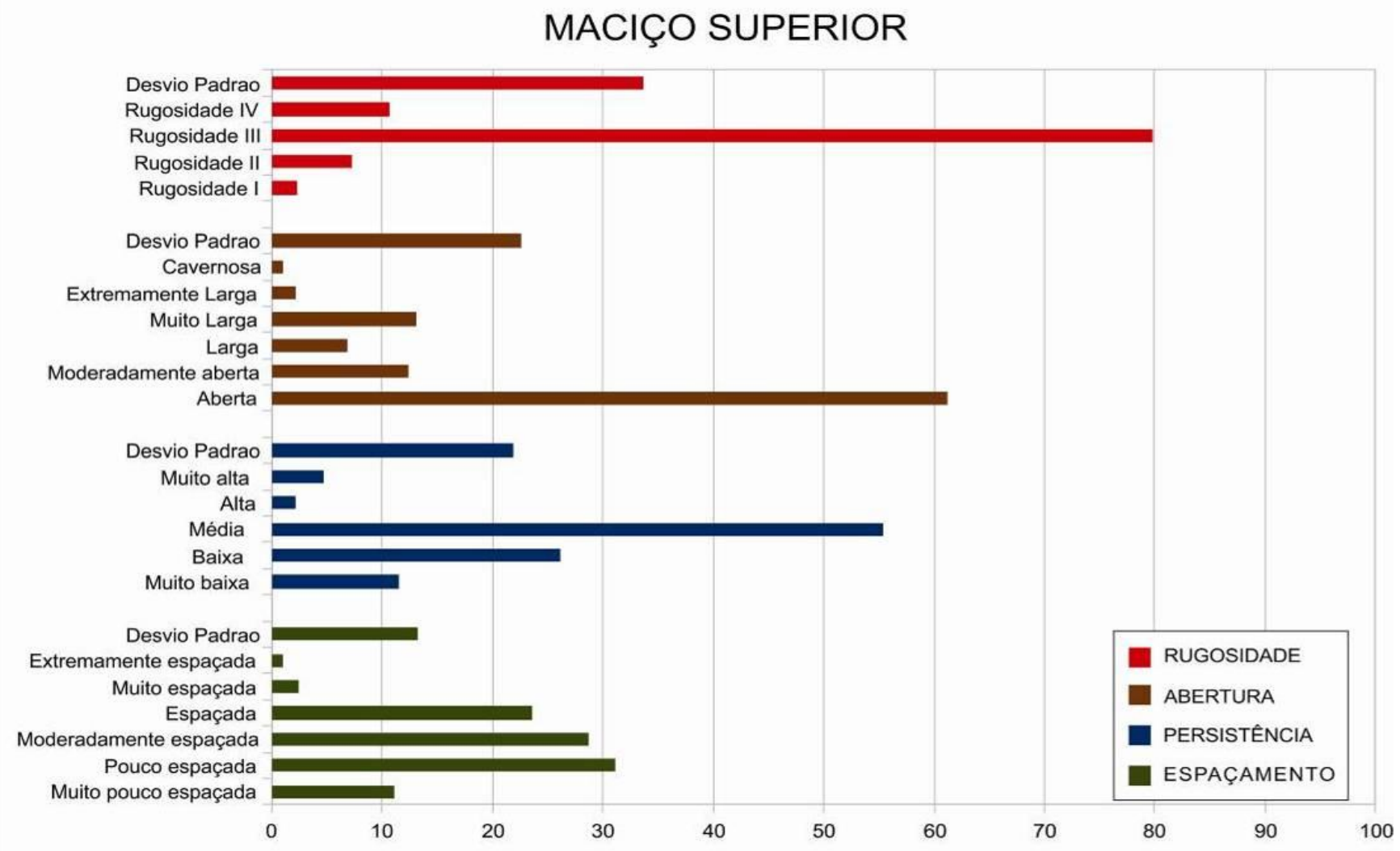

Figura 3.23 - Parâmetros diagnosticados do levantamento sistemático, do intervalo superior do Maciço rochoso.

O preenchimento não foi individualizado nas figuras, tendo em vista a baixa representatividade diagnosticada. Quando ocorre, está comumente vinculado a zonas de cisalhamento, principalmente nos intervalos superior e intermediário. Pôde-se constatar que, composicionalmente, constituem-se da alteração de minerais máficos, notadamente biotita (formando biotititos), que enriquecem as regiões das zonas de cisalhamento. Nesses casos, constituem fator inibidor a presença de fluxo, dada a baixa porosidade dos argilominerais formados. 


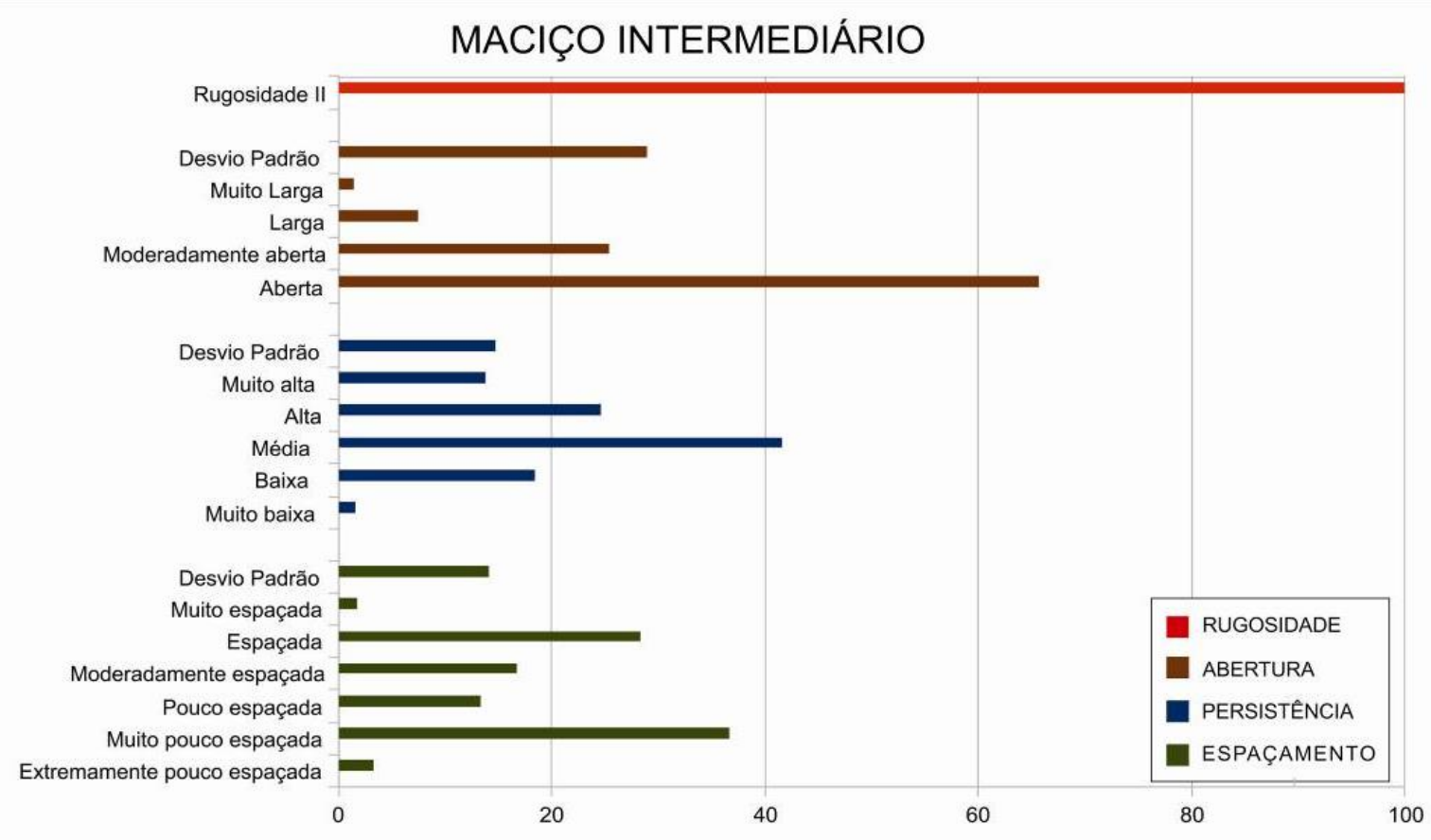

Figura 3.24 - Parâmetros diagnosticados do levantamento sistemático, do intervalo intermediário do Maciço rochoso.

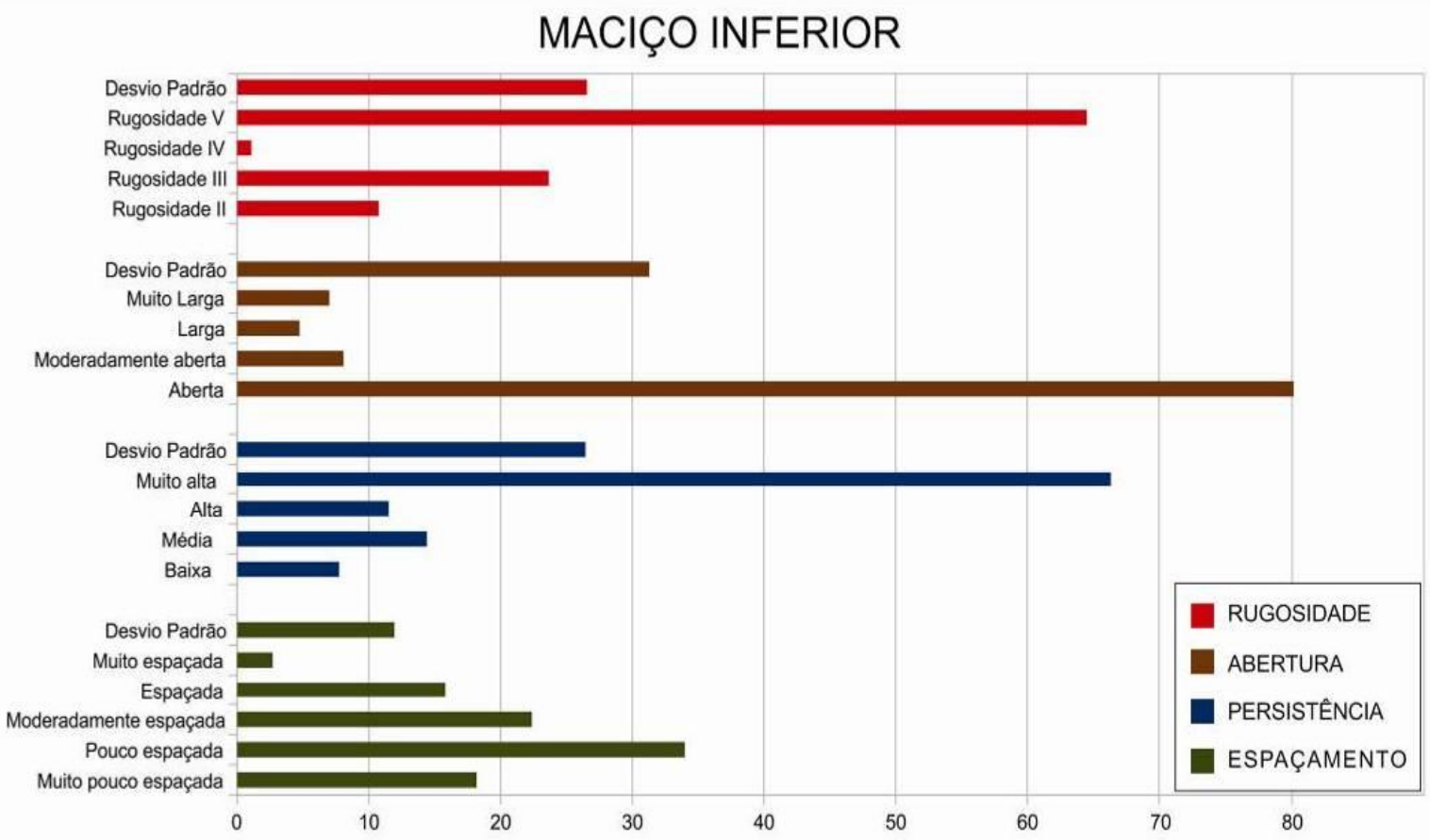

Figura 3.25 - Parâmetros diagnosticados do levantamento sistemático, do intervalo inferior do Maciço rochoso.

No tocante a rugosidade, no que diz respeito às famílias de estruturas definidas neste trabalho, nota-se que no caso das anisotropias com mergulho para SW-W-NW a rugosidade predominante pertence a classe III. Com relação a família sub-horizontal esse parâmetro distribui-se entre as classes II, III e V. Quanto a família NE, a rugosidade concentra-se na classe V. Pode-se dizer que, em relação aos aspectos geotécnicos, a rugosidade favorece a resistência 
ao cisalhamento, conferindo um incremento ao ângulo de atrito, segundo Serra Junior e Ojima (1998). Já em relação a natureza do fluxo de água, esse parâmetro tem implicação direta (fluxo laminar ou turbulento). Sendo assim, considerando que o objeto desse estudo não considera este nível de detalhamento, e limita-se a estabelecer um modelo conceitual do aquífero, a delimitação das classes de rugosidade foi suficiente.

Considerando os resultados supracitados, construiu-se representação gráfica simplificada da distribuição das descontinuidades do maciço rochoso, até a profundidade analisada (Figura $3.26)$.

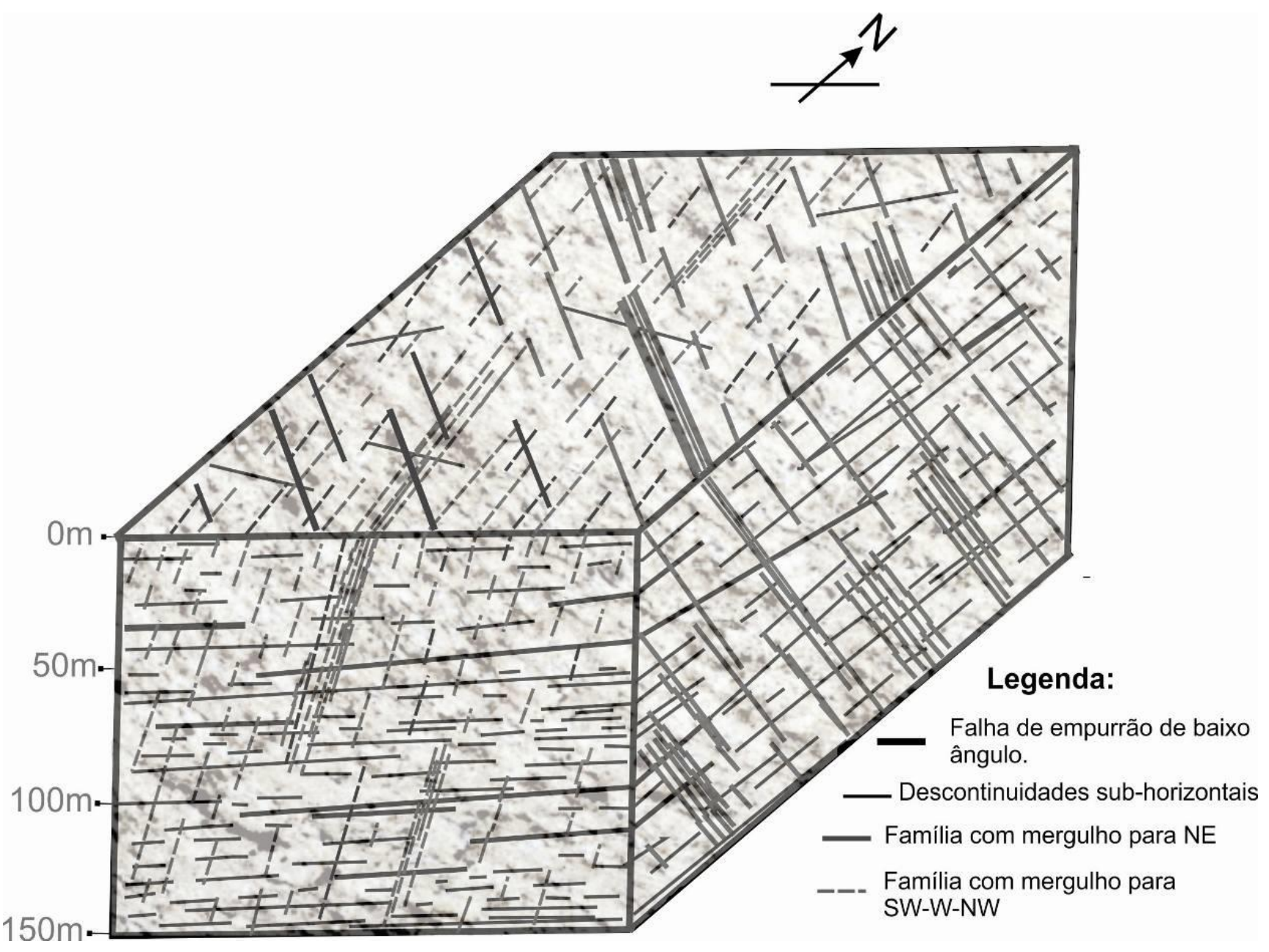

Figura 3.26 - Proposta de modelo representativo da distribuição das descontinuidades no maciço.

\subsection{CONSIDERAÇÕES FINAIS}

De acordo com os resultados obtidos unicamente do levantamento sistemático das descontinuidades, pode-se afirmar que o aquífero fraturado é um sistema livre e aberto. Existem três famílias de descontinuidades principais que o compõem, as famílias NE, SW-W-NW e Subhorizontal. A primeira e a segunda são especialmente responsáveis pela recarga, já a terceira responde pela interconexão de todo o sistema.

A parte superior do maciço apresenta-se com volume maior de anisotropias, pouco espaçadas e com persistências mais baixas, formando uma zona bastante fragmentada. Com a 
profundidade, predominam estruturas mais penetrativas e com espaçamentos maiores entre si, representadas principalmente pela família NE. Essas descontinuidades têm papel fundamental na recarga dessas zonas mais profundas, e a existência de fluxo d'água. Ainda existem zonas de cisalhamento que, quando não preenchidas, suas aberturas constituem caminhos preferenciais ao fluxo, em virtude de representarem zonas penetrativas no maciço.

As estruturas sub-horizontais persistem até a profundidade de 150 metros, garantindo a interconexão do sistema aquífero em toda a massa de rochas analisada. Este dado indica que o senso comum de que a profundidade máxima dos poços em aquíferos cristalinos do semiárido do nordeste deve ser inferior a 100 metros pode estar equivocado. Há possibilidade real de que, pelo menos ao longo das principais zonas de cisalhamento, ocorram poços com entradas d'água a maiores profundidades (como no caso estudado).

A importância das anisotropias sub-horizontais é evidenciada na cava da Mina de Urânio que mostra percolação de água mais intensa e evidente que as estruturas verticais ou de elevado ângulo.

O modelo conceitual do aquífero estudado pode ser considerado como um tipo fraturado clássico, pois o conjunto de rochas não apresenta nenhuma porosidade intergranular ou espaços matriciais residuais, por se tratar de rochas metamórficas de alto grau ou rochas plutônicas.

Os resultados obtidos devem ser aplicados para a previsão do fluxo de plumas de contaminação, para locação de novos poços, para locação de sítios de recarga e demais ações para a gestão dos aquíferos fraturados em estudo, especialmente no que se refere ao fechamento da mina, quando findar o bombeamento dos poços e o fluxo da água subterrânea voltar ao estado natural.

Para a localização de seções aquíferas potencialmente produtoras os pontos prioritários para a locação de poços encontram-se nas zonas de intersecção de anisotropias das famílias NE com aquelas associadas à Família SW-W-NW. Como as estruturas sub-horizontais são persistentes até maiores profundidades o sucesso na explotação da água subterrânea é significativamente ampliado.

A fim de reduzir as dificuldades de determinação das estruturas em locais com maior cobertura de solos sugere-se a aplicação de estudos geofísicos. Mesmo os métodos que estudam pequenas profundidades são úteis, uma vez que nas regiões semiáridas as coberturas pedológicas são pouco espessas (Pádua et al. 2013). 


\section{CAPÍTULO IV}

\section{HIDROQUÍMICA}

\subsection{Introdução}

Este capítulo de Hidrogeoquímica tem o propósito de tecer a caracterização química do aquífero estudado, com base nas análises físico-químicas que a INB realiza, periodicamente, em poços para captação de água, com diversas finalidades. Mais especificamente, considerando questões de caráter socioambiental, principalmente no que se refere às concentrações de urânio nas águas, espera-se contribuir com o esclarecimento das possíveis fontes desse radionuclídeo, bem como, identificar relações com atividades antrópicas, caso existam. Ainda, de acordo com as variações dos teores dos elementos amostrados nos poços, ao longo do tempo, pretende-se buscar indícios de comunicação no aquífero, e características que possam colaborar com o entendimento do modelo conceitual proposto para o aquífero, no capítulo anterior.

Importa ressaltar que o enfoque dado a avaliação dos dados não se refere a comparações entre os valores encontrados, com os limites estabelecidos para consumo humano. Neste trabalho buscou-se estabelecer correlações estritamente com o meio físico, que no caso refere-se a estrutura do aquífero (matriz rochosa e descontinuidades), assim como ao clima da região.

As Indústrias Nucleares do Brasil (INB) analisam parâmetros físico-químicos, tanto das águas dos poços de abastecimento, quanto daqueles destinados ao monitoramento da água subterrânea. As amostras de água subterrânea analisadas foram extraídas de poços tubulares de abastecimento da usina e de comunidades de rurais, localizados em um raio de $15 \mathrm{~km}$ da mineração de urânio. Essas análises químicas e radiológicas foram efetuadas entre janeiro de 1998 e setembro de 2013. No total foram 28 poços de abastecimento (PCs), 9 poços para abastecimento humano (LRs) e 40 poços de monitoramento (PMs). As análises históricas disponibilizadas foram:

a) Parâmetros físico-químicos: $\mathrm{pH}$, alcalinidade, condutividade e dureza;

b) Dados químicos (em mg/L): $\mathrm{Na}, \mathrm{K}, \mathrm{Mg}, \mathrm{Ca}, \mathrm{Ba}, \mathrm{Mn}, \mathrm{Fe}, \mathrm{Al}, \mathrm{SiO}_{2}, \mathrm{SO}_{4}, \mathrm{~F}, \mathrm{Cl}, \mathrm{NO}_{3}$, $\mathrm{N}$ (amoniacal) e $\mathrm{NO}_{2}$ para determinados poços;

c) Radioatividade (em Bq/L): U natural, ${ }^{226} \mathrm{Ra},{ }^{228} \mathrm{Ra}$, Th natural e ${ }^{210} \mathrm{~Pb}$.

Além dos dados supracitados, obteve-se os perfis construtivos dos poços de abastecimentos, informações sobre o nível estático e dinâmico desses poços, vazões máximas obtidas nos testes de bombeamento, mapas Geológico, Pedológico, carta Topográfica, localização dos poços de abastecimento, e etc.Essas informações basearam toda a análise que se segue. 
A metodologia adotada para tratamento dos dados consistiu da elaboração de gráficos que relacionaram os valores encontrados, para cada parâmetro, ao histórico de amostragens disponibilizado. Além disso, buscaram-se os valores da média, mediana, máximos e mínimos, terceiro quartil e primeiro quartil, de cada parâmetro em cada um dos poços, para construção dos Box-Plots, com vistas a ilustrar o comportamento dos dados químicos estudados.

O objetivo dessa etapa foi fazer um diagnóstico geral do aquífero, relacionar os dados levantados nos poços a geologia da área e verificar as diferenças de comportamento. O próximo passo consistiu na determinação dos valores de background para alguns elementos analisados, escolhidos com base nos resultados da etapa anterior e nas questões socioambientais, especialmente aquelas relativas à ocorrência de teores de urânio nas águas subterrâneas, que resultam em sérios problemas para a população, do ponto de vista da desinformação. Finalmente, a partir das anomalias detectadas foram averiguadas as correlações entre elas e indícios de comunicação no aquífero.

\subsection{Diagnóstico do Aquífero}

O domínio das rochas cristalinas, que predomina na região de estudo, em associação ao clima semiárido, favorece a presença de sistemas aquíferos fraturados. Nos vales dos principais cursos d'água da área, o nível da água subterrânea é mais raso, por vezes atingindo a camada de sedimentos constituída por solo residual das rochas do embasamento, coberturas detríticas terciário-quaternárias e depósitos aluvionares. Entretanto, em consequência do déficit hídrico que prejudica a recarga desses aquíferos sedimentares, sua importância, enquanto fonte de abastecimento torna-se restrita e inexpressiva. Nesse sentido, os aquíferos fraturados representam a principal fonte para captação de água destinada ao uso da população.

De acordo com Geocervices (2004), que utilizou a classificação através do diagrama de Piper, para 14 amostras de águas subterrâneas, sendo uma amostra de água por poço tubular estudado, as águas foram classificadas como bicarbonatadas sódicas (Figura 4.1). Ainda, o predomínio do ânion bicarbonato e do cátion sódio nas amostras de água subterrânea analisadas são típicas de aquíferos associados a rochas graníticas ou metamórficas de protolito granítico, principalmente quando submetidas a processos de albitização que substitui o potássio pelo sódio. 


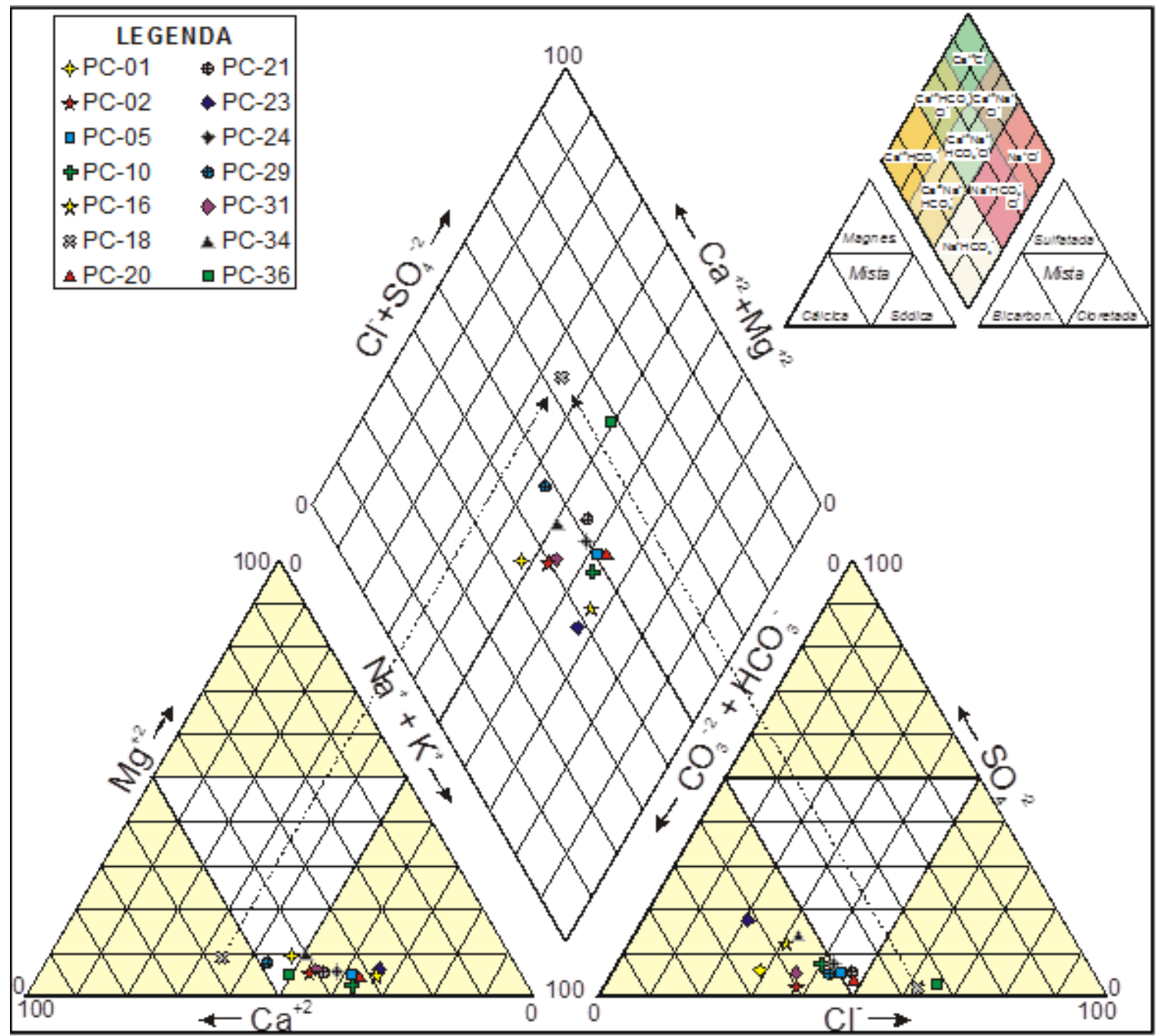

Figura 4.1 - Diagrama de Piper para 14 amostras de água subterrânea analisadas em fevereiro de 2003. (Geocervices, 2004).

De acordo com os perfis construtivos dos poços, os PCs 01, 02, 20, 23 foram perfurados em rochas gnáissicas. Os PCs 05, 10, 16, 18, 24, 29, foram instalados no Granito São Timóteo. Já os poços 34 e 36 situam-se no contato entre gnaisses e o dique de diabásio (Figura 4.2). Observa-se que, de forma geral, a natureza da rocha, no caso de granitos e gnaisses, não resultou em distinções significativas nas classificações químicas das águas. 
MAPA DE LOCALIZAÇÃO DOS POÇOS NA ÁREA DO COMPLEXO MINERO INDUSTRIAL

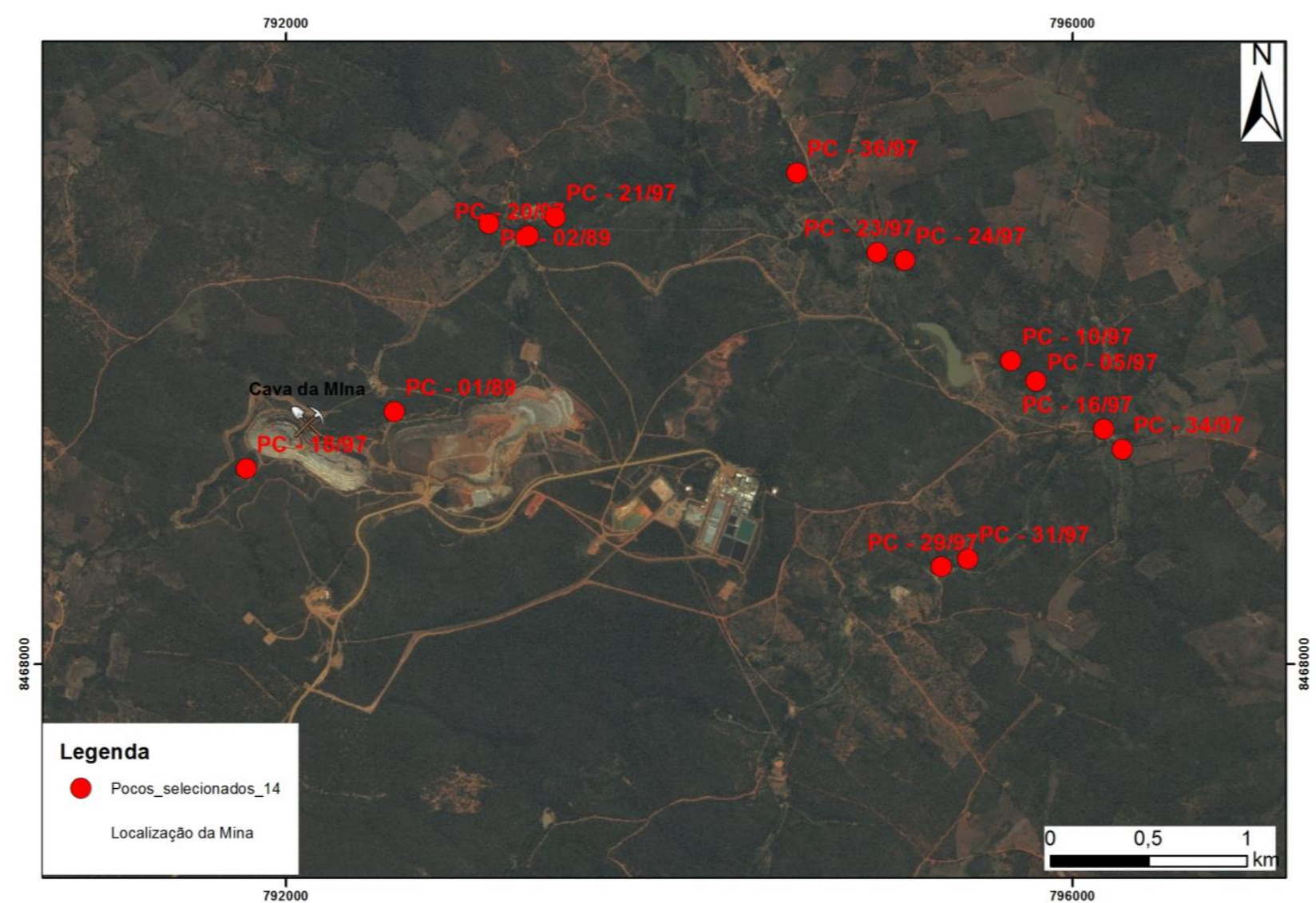

Figura 4.2 - Mapa com a localização dos poços amostrados, para classificação das águas através do Diagrama de Piper.

A fim de caracterizar o aquífero, com base nas análises químicas dos poços, disponibilizadas pela INB, optou-se por utilizar aqueles destinados ao abastecimento (PCs). Para esses poços foram disponibilizados, além das análises químicas, dados como coordenadas, nível estático, nível dinâmico, vazão e perfis construtivos. Incluindo os poços que não são produtivos (poços secos) existem 166 pontos de monitoramento. Destes foram selecionados aqueles com dados completos, ou seja, análises físico-químicas, perfis construtivos, coordenadas, NE, ND e vazão, num total de 28 poços produtores (Figura 4.3 e Anexo 01 - Mapa com localização dos poços da INB). 


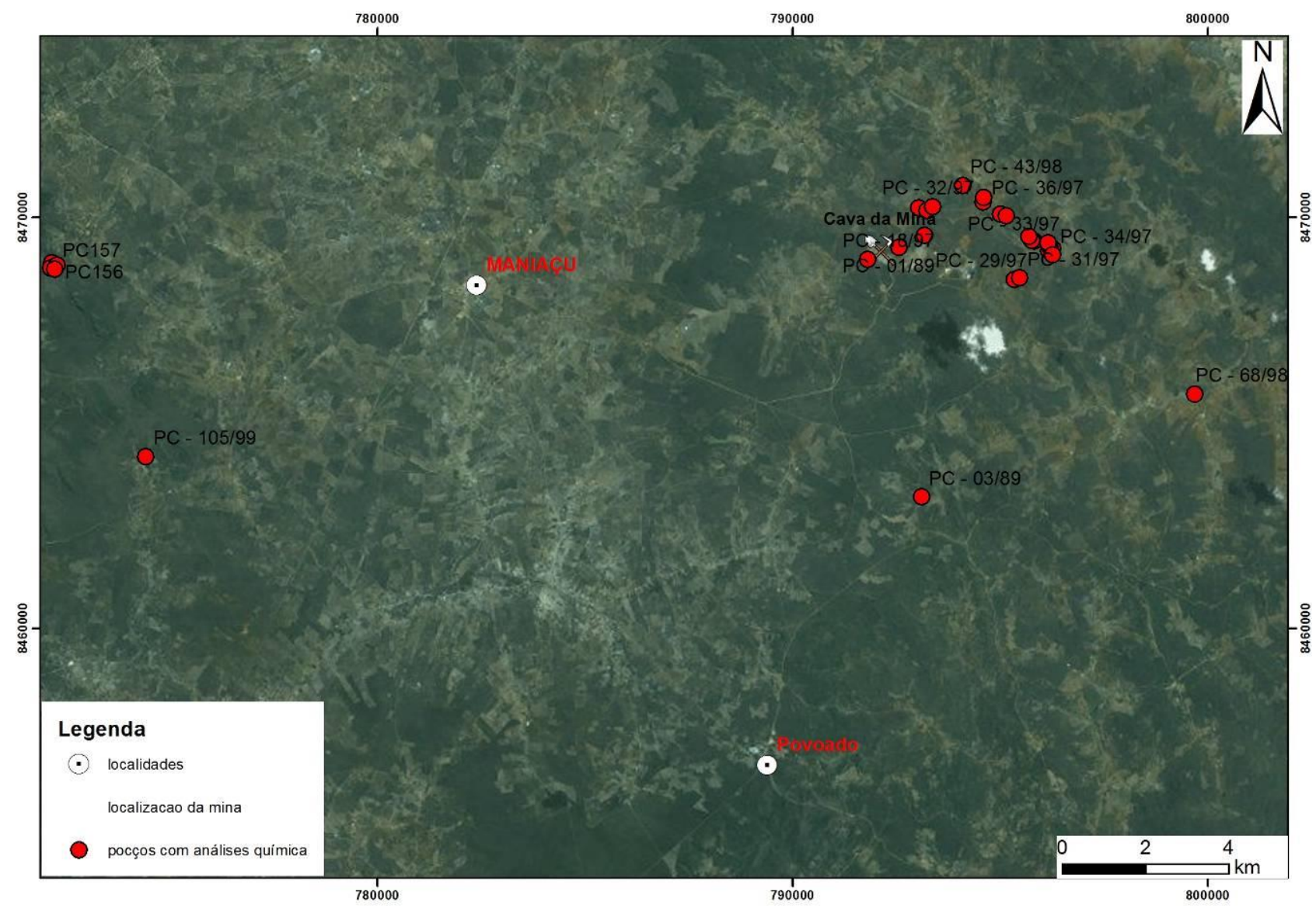

Figura 4.3 - Localização dos poços 28 poços adotados para as avaliações hidroquímicas.

Os dados estão separados entre parâmetros estáveis e os radionuclídeos. No primeiro grupo encontram-se $\mathrm{Na}, \mathrm{K}, \mathrm{Mg}, \mathrm{Ca}, \mathrm{Ba}, \mathrm{Mn}, \mathrm{Fe}, \mathrm{Al}, \mathrm{SiO}_{2}, \mathrm{SO}_{4}, \mathrm{~F}, \mathrm{Cl}, \mathrm{NO}_{3}$, N. Já no segundo têmse o $\mathrm{U}$ natural, ${ }^{226} \mathrm{Ra},{ }^{228} \mathrm{Ra}$, Th natural e ${ }^{210} \mathrm{~Pb}$. Como pode ser observado a partir do Mapa Geológico (Figura 4.4) e dos perfis construtivos dos poços, aqueles poços construídos dentro dos limites do complexo mínero-industrial, bem como os PCs - 03 e 68 foram instalados em ortognaisses do Grupo Lagoa Real ou em rochas graníticas da Suíte São Timóteo. O poço 105 encontra-se construído em quartzito, e os poços 137, 155, 156 e 157, segundo o Mapa Geológico, foram perfurados em cobertura detrito-laterítica, e em profundidade atravessam Quartzito ou rocha metapiroclástica (Metariolito e Metadacito). Para estes quatro últimos poços não foram disponibilizados os respectivos perfis construtivos, entretanto, sua análise é fundamental, pois retratam tipos petrográficos distintos e pontos distantes daqueles instalados dentro dos limites de atuação da INB. 


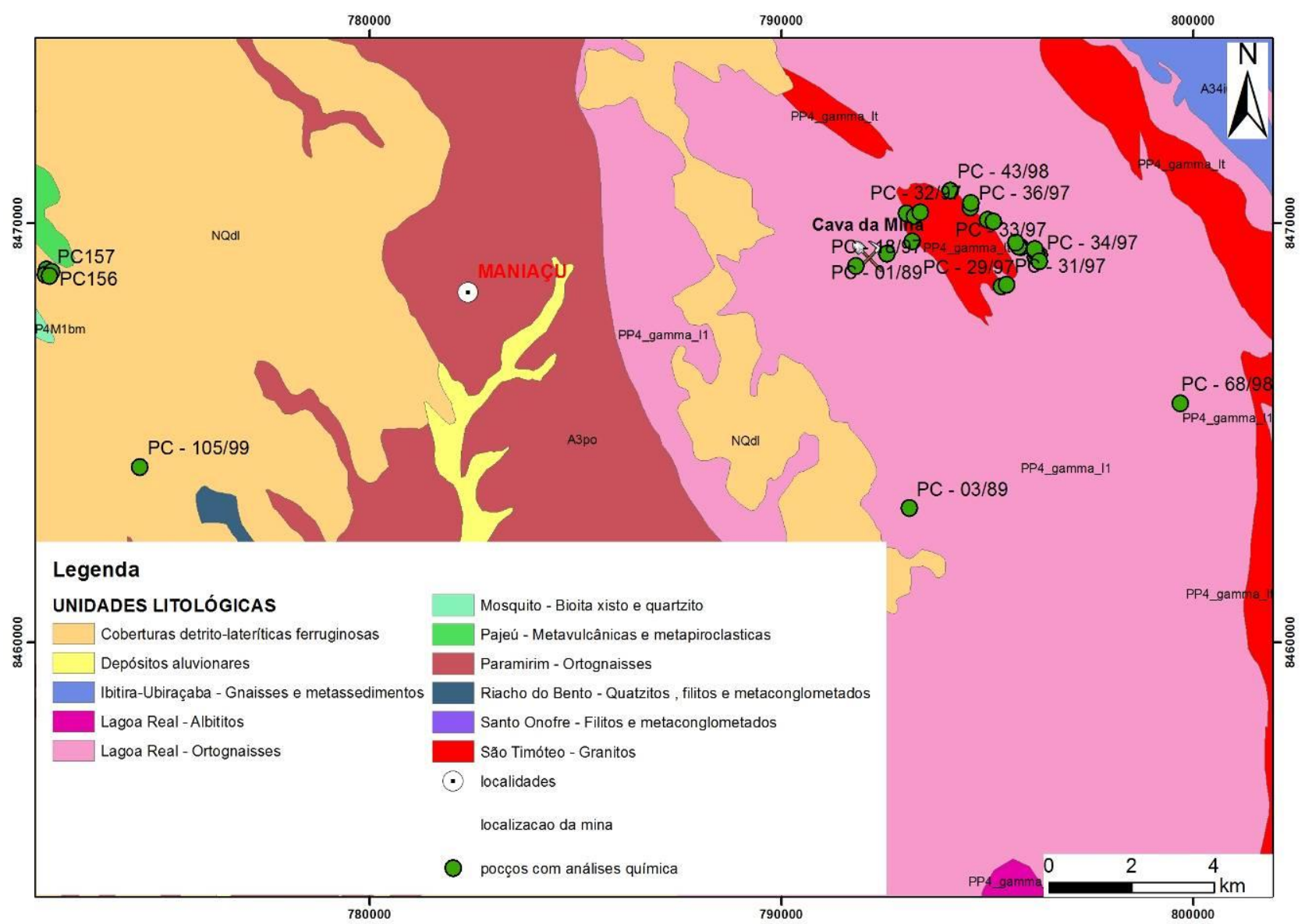

Figura 4.4 - Mapa Geológico com a localização dos poços 28 poços adotados para o estudo hidroquímico.

\subsubsection{Distribuições de Sódio e Cálcio}

De acordo com Feitosa \& Filho (2000), o cálcio é um dos principais constituintes das águas e responsável primordial pela sua dureza. Ocorre principalmente nos minerais de calcita e, nas rochas ígneas e as principais fontes de cálcio são o plagioclásio rico em anortita e a apatita. Nas águas meteóricas os teores de Ca variam entre 0,1 a $10 \mathrm{mg} / \mathrm{L}$. Já nas águas subterrâneas, suas concentrações encontram-se entre 1 e 100 mg/L.

No que se refere ao sódio, pode-se afirmar que é o metal alcalino mais importante e abundante nas águas subterrâneas. Nas rochas ígneas as principais fontes de $\mathrm{Na}$ correspondem aos plagioclásios ricos em albita, feldspatóides (nefelina e sodalita), anfibólios e piroxênios.

Considerando a geologia da área, o metassomatismo que deu origem aos albititos mineralizados em urânio do Complexo Lagoa Real ocorreu em duas fases principais: (i) metassomatismo sódico, permitindo a substituição do feldspato potássico pelo plagioclásio sódico e neoformação da albita, a formação de piroxênio sódico, com dessilicificação dos minerais; (ii) metassomatismo cálcico, acompanhado de desidratação do anfibólio, transformando-o em piroxênio e granada, neoformação de piroxênio, granada, calcita e fluorita, sendo essas duas últimas tardias. Nesse sentido, o sódio encontrado nas águas está intimamente ligado ao processo de lixiviação dos corpos de albititos. O cálcio é originado preferencialmente de cristais de calcita encontrados em rochas do Complexo Lagoa Real. 
O sódio apresenta concentrações elevadas, no conjunto representado por todos os poços analisados. Observa-se, entretanto, que nas regiões onde as rochas correspondem a gnaisses e granitos, as concentrações são 4,5 vezes maiores, em relação aos quartzitos e rochas metapiroclásticas (Tabela 4.1). Já o cálcio encontra-se dentro do esperado para águas subterrâneas, exceto por anomalia diagnosticada no PC- 113, instalado em rocha gnáissica (Tabela 4.2).

\begin{tabular}{|l|c|c|c|}
\hline \multicolumn{1}{|c|}{ Na mg/L } & Geral & Fora-área & Dentro-área \\
\hline máximo & 324 & 152,28889 & 324 \\
\hline Q3 & 150,7717 & 47,472769 & 186,1409242 \\
\hline média & 124,4189 & 32,585941 & 149,464213 \\
\hline mediana & 110,9456 & 9,5338462 & 124,4548344 \\
\hline Q1 & 86,01643 & 5,91875 & 94,86462121 \\
\hline Mínimo & 5,6 & 5,6 & 30,495 \\
\hline
\end{tabular}

Tabela 4.1 - Distribuição média da concentração de Na nas águas subterrâneas em mg/L.

\begin{tabular}{|l|l|l|l|}
\hline \multicolumn{1}{|c|}{ Ca mg/L } & Geral & Fora-área & Dentro-área \\
\hline máximo & 313,9911 & 58,341923 & 313,9910526 \\
\hline Q3 & 85,26763 & 25,181181 & 92,15580357 \\
\hline média & 71,36191 & 18,784073 & 85,70131503 \\
\hline mediana & 67,88375 & 12,048825 & 73,16175629 \\
\hline Q1 & 44,11586 & 9,1517975 & 61,88471812 \\
\hline Mínimo & 5,902306 & 5,9023056 & 16,25272727 \\
\hline
\end{tabular}

Tabela 4.2 - Distribuição média da concentração de Ca nas águas subterrâneas em mg/L.

Essa diferença pode ser mais bem compreendida através do exame dos gráficos, com a distribuição das concentrações desses parâmetros nas águas subterrâneas, visto nos poços instalados em cada um desses domínios. Toma-se como exemplo os seguintes poços: PC 18 situado a montante das cavas e construído no Granito São Timóteo (Figura 4.5), PC 68 localizado fora da área do complexo da INB e instalado em rocha gnáissica (Figura 4.6) e PC 105 - posicionado longe da área do complexo e implantado em quartzito (Figura 4.7).
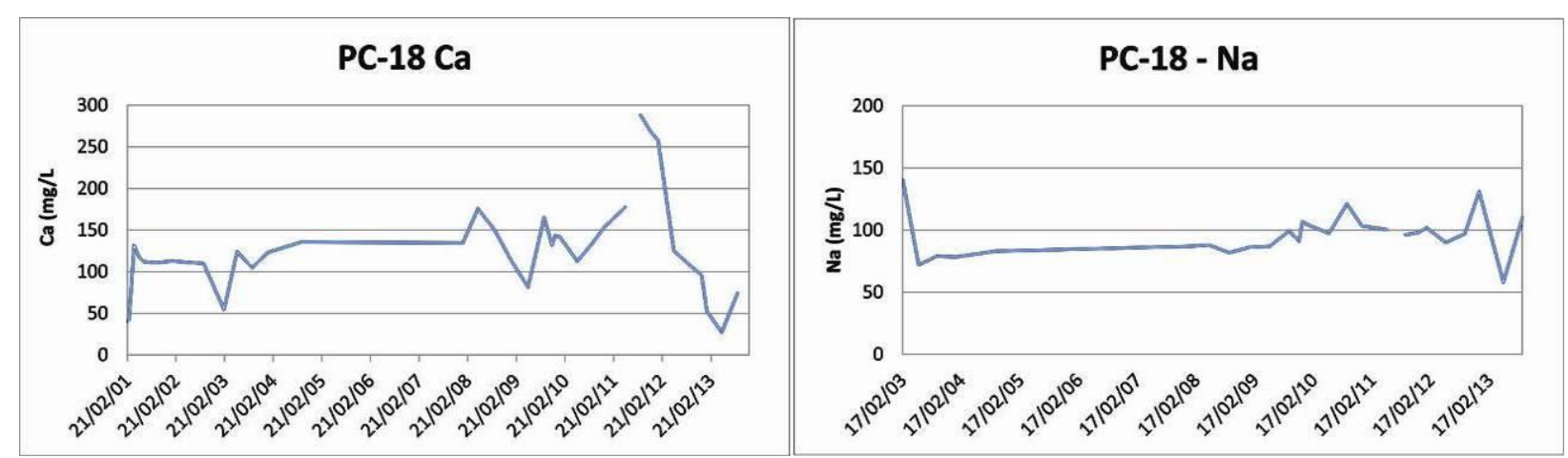

Figura 4.5 - Concentração de Na e Ca no poço PC - 18. 


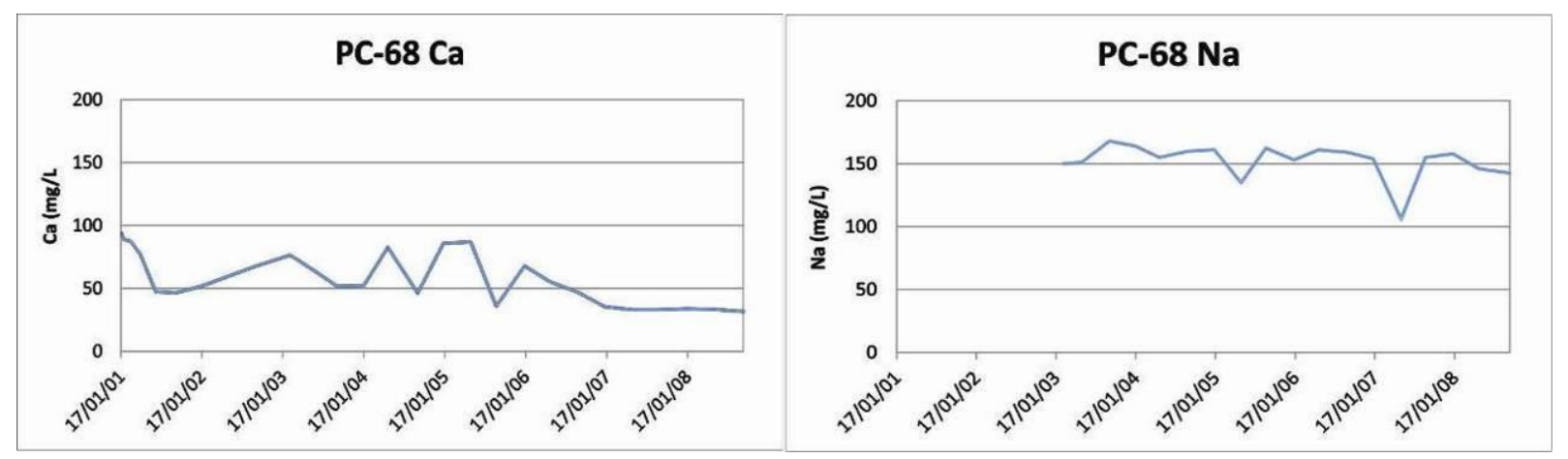

Figura 4.6 - Concentração de Na e Ca no poço PC - 68.

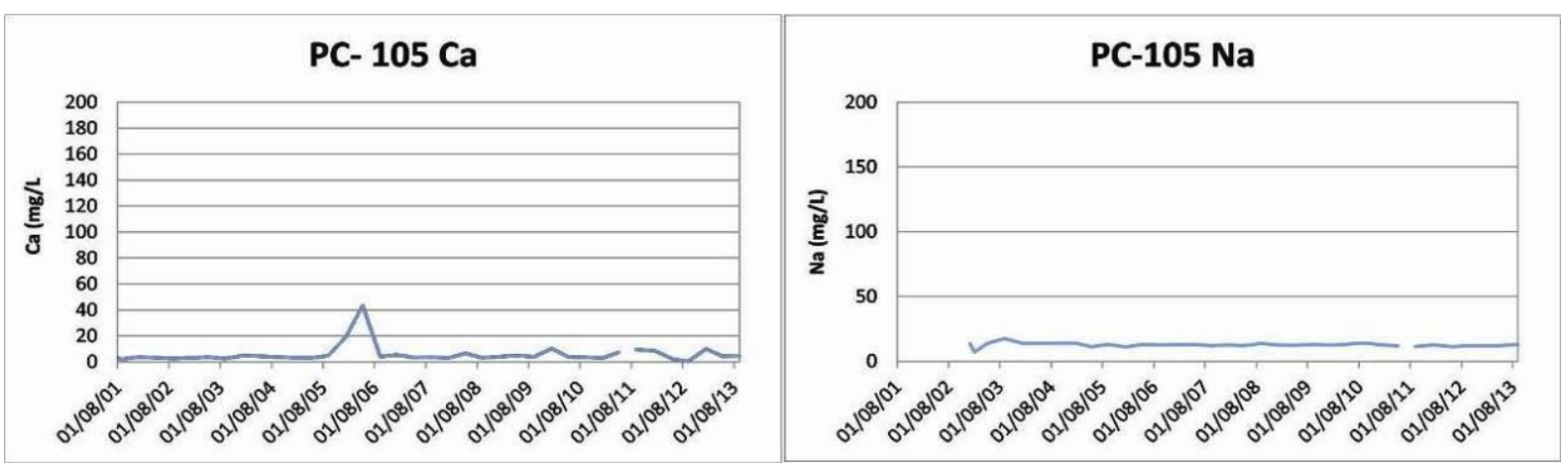

Figura 4.7 - Concentração de Na e Ca no poço PC - 105.

De acordo com o contexto geológico (Figura 4.4) esses poços estão consideravelmente distantes para haver qualquer tipo de comunicação, principalmente considerando a natureza fraturada do aquífero. As concentrações desses parâmetros analisados nas rochas graníticas e gnáissicas corroboram com os teores de sódio e cálcio (Tabelas 4.1 e 4.2), que representa o comportamento da distribuição desses elementos, com base nas concentrações médias obtidas em todos os poços.

Apesar de localizar-se dentro dos limites do complexo mínero-industrial, o PC 18 está a montante das cavas. Nesse sentido, não há escoamento superficial que o atinja e, também não existe contaminação por água subterrânea que possa ter percolado a partir das áreas com exposição de rocha (no caso as três cavas). O PC 68 acha-se em área livre de atividade voltada para mineração, todavia também apresenta concentrações semelhantes aos poços perfurados dentro da área da INB.

Conclui-se que a concentração elevada de $\mathrm{Na}$ nessas águas relaciona-se com o intemperismo dos albititos encontrados em toda a área de ocorrência dos gnaisses do Complexo Lagoa Real. Por outro lado, o cálcio está fortemente vinculado à dissolução de cristais de calcita (Figuras 4.8 e 4.9). Inclusive, em alguns pontos nos gnaisses podem-se observar áreas mais ricas em carbonatos, denominadas como "bolsões carbonáticos". Além disso, nas rochas ígneas e metamórficas pode-se considerar fonte de cálcio os feldspatos cálcicos, anfibólios e piroxênios, sendo que na área, durante o metamorfismo em fácies anfibolito, ao longo de zonas de cisalhamento, alguns estágios de alteração metassomática propiciaram a transformação da hornblenda em piroxênio, e esse mineral pode ser considerado a fonte secundária de cálcio. 


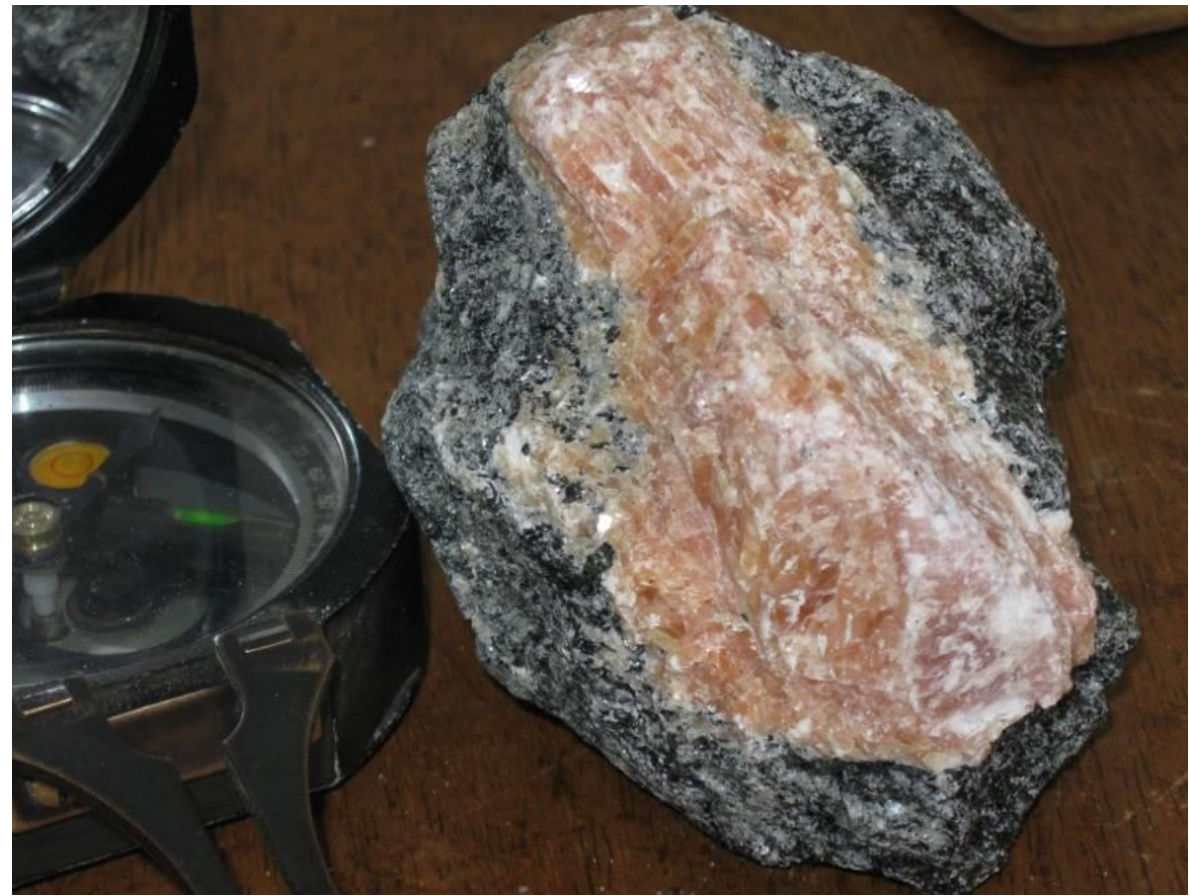

Figura 4.8 - Mineral de Calcita encontrado no gnaisse.

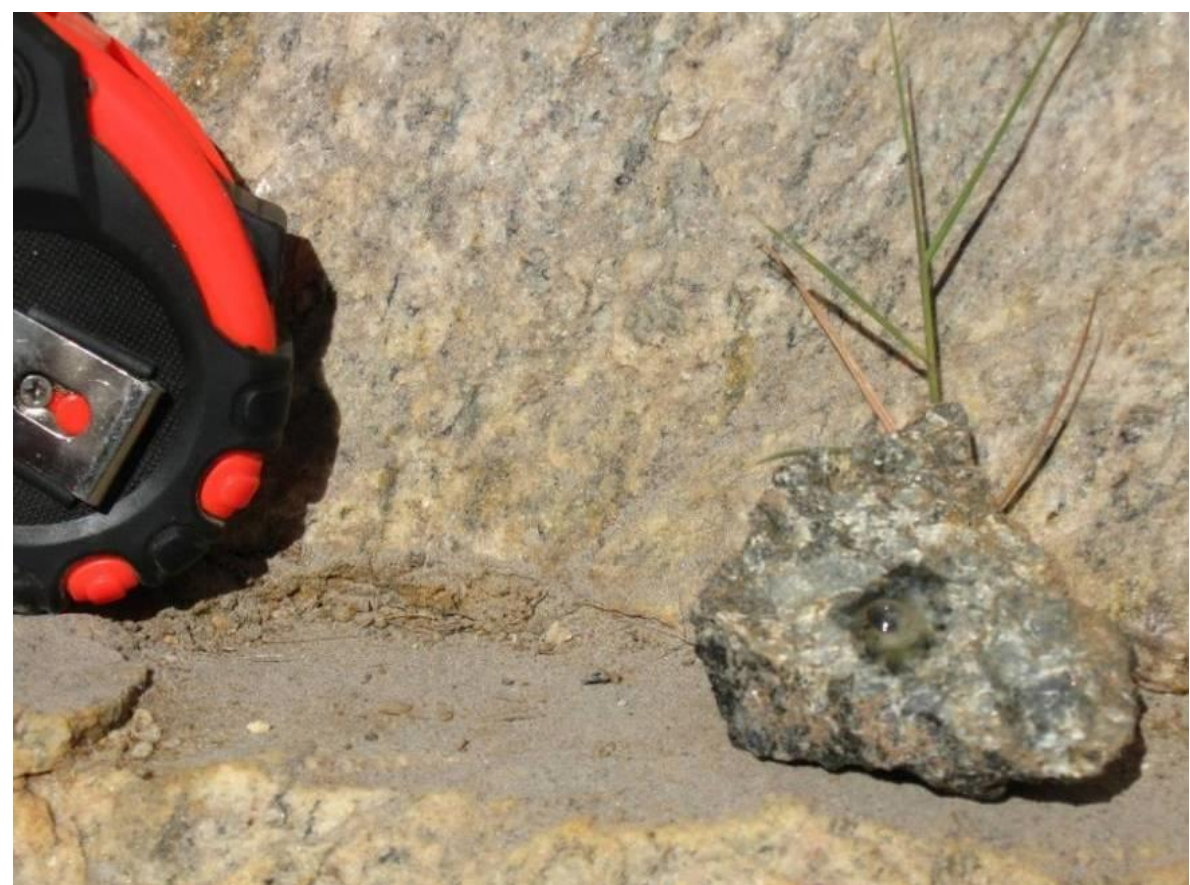

Figura 4.9 - Calcita reagindo na presença de ácido clorídrico.

\subsubsection{Distribuição do Potássio}

Segundo Feitosa \& Filho (2000), este elemento ocorre em pequenas quantidades nas águas subterrâneas, graças a sua participação intensa em processos de troca iônica, bem como pela facilidade de ser adsorvido pelos minerais de argila, e ainda, por ser bastante utilizado pelos vegetais. O potássio ocorre principalmente nos cristais de feldspato potássico, muscovita e leucita, em rochas ígneas e metamórficas. Nas águas meteóricas seus teores variam entre 0,1 e 4 mg/L. Já nas águas subterrâneas suas concentrações, em condições normais, encontram-se abaixo de $10 \mathrm{mg} / \mathrm{L}$. 
A influência da composição química dos minerais que formam as rochas, em se tratando das concentrações desse elemento encontrado nas águas, pode ser melhor entendida comparando o conteúdo de sódio e cálcio com o potássio. A distribuição desse parâmetro (Tabela 4.3), tanto dentro da área da INB quanto fora, não apresenta diferença significativa de sua concentração nessas regiões analisadas. Isto se dá em função do K-feldspato não ser tão abundante nessas rochas, em decorrência do processo de metassomatismo sódico (uma das fases que originou os corpos de albititos mineralizados), que provocou a substituição do feldspato potássico pelo plagioclásio sódico e neoformação da albita. Obviamente, nas rochas graníticas e gnáissicas a quantidade constatada supera aquela observada em quartzitos, por exemplo, entretanto, mesmo assim, essa diferença não chega a ser tão discordante quanto no caso anterior.

\begin{tabular}{|l|l|c|c|}
\hline K mg/L & Geral & Fora-área & Dentro-área \\
\hline máximo & 20,54807 & 7,36038462 & 20,54807018 \\
\hline Q3 & 11,78445 & 6,11217949 & 12,83739765 \\
\hline média & 9,027807 & 3,23201211 & 10,60847828 \\
\hline mediana & 9,386463 & 1,68153846 & 9,6982 \\
\hline Q1 & 5,842781 & 1,499375 & 7,856138716 \\
\hline Mínimo & 1,46 & 1,46 & 4,075 \\
\hline
\end{tabular}

Tabela 4.3 - Distribuição média da concentração de K nas águas subterrâneas em mg/L.

De acordo com o Box-Plot para o potássio (Figura 4.10), depreende-se que os poços localizados fora da área do complexo mínero-industrial são 3,28 vezes menores que aqueles dentro da área. Conforme elucidado acima, a exceção do PC 68, todos os demais poços externos a área do complexo, não foram perfurados em rocha granítica ou gnáissica. A maioria compreende rochas quartzíticas e, possivelmente, metapiroclásticas, e certamente mais empobrecidas em K. Mais uma vez se evidencia que a composição da rocha influencia diretamente na constituição química das águas.

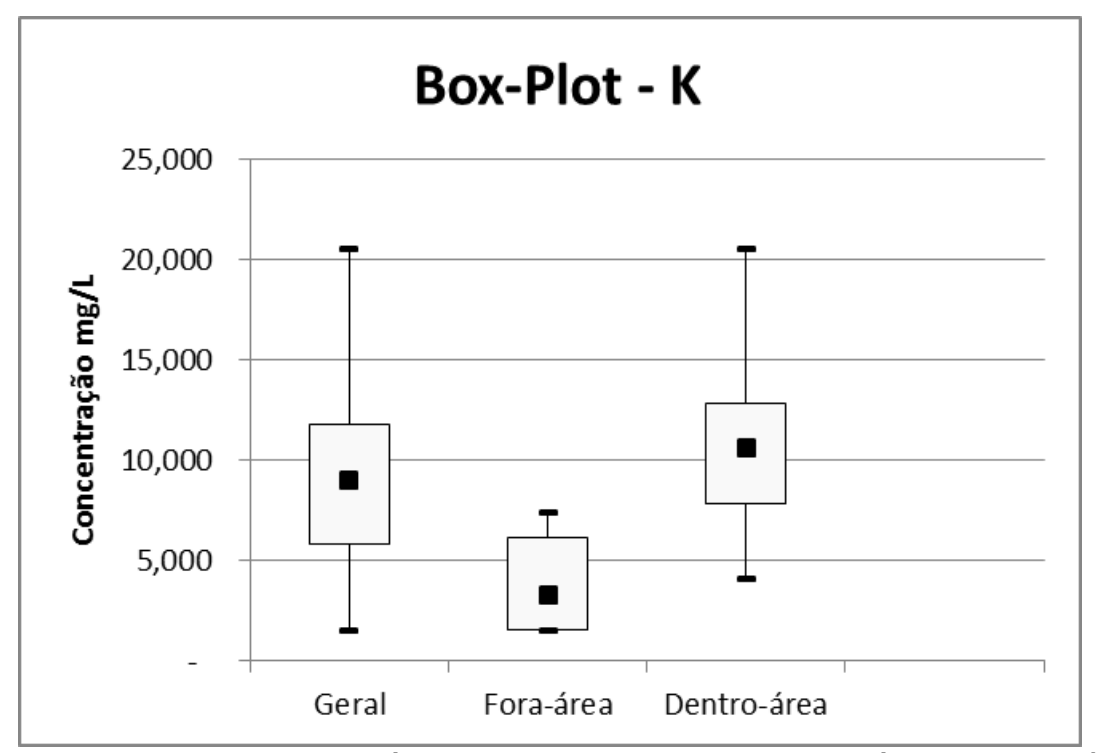

Figura 4.10 - Box-Plot da distribuição média da concentração de K nas águas subterrâneas em mg/L. 
Considerando os mesmos poços usados no exemplo anterior, PC 18 (granito-dentro do complexo), PC 68 (gnaisse - fora do complexo) e PC 105 (quartzito - fora do complexo), nota-se, nos gráficos com a distribuição das concentrações ao longo do tempo (Figuras 4.11, 4.12 e 4.13), que o potássio, no gnaisse e no Granito São Timóteo, apresenta valores semelhantes, a exceção de picos anômalos. Já no quartzito a concentração se mantém baixa ao longo do tempo (exceto por um único pico, que certamente representa uma anormalidade ou erro de análise).

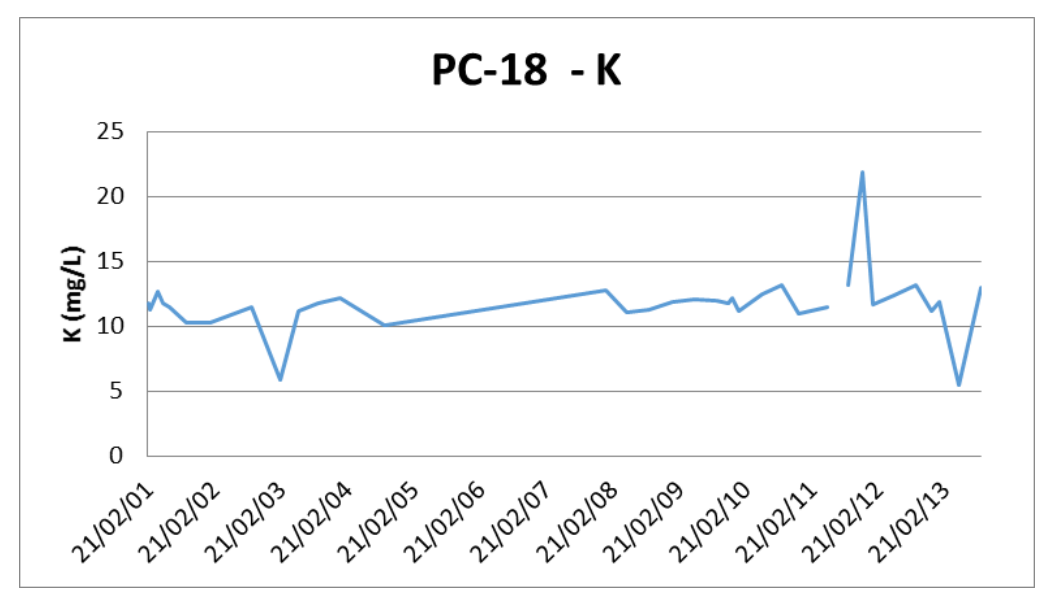

Figura 4.11 - Concentração de K no PC 18.

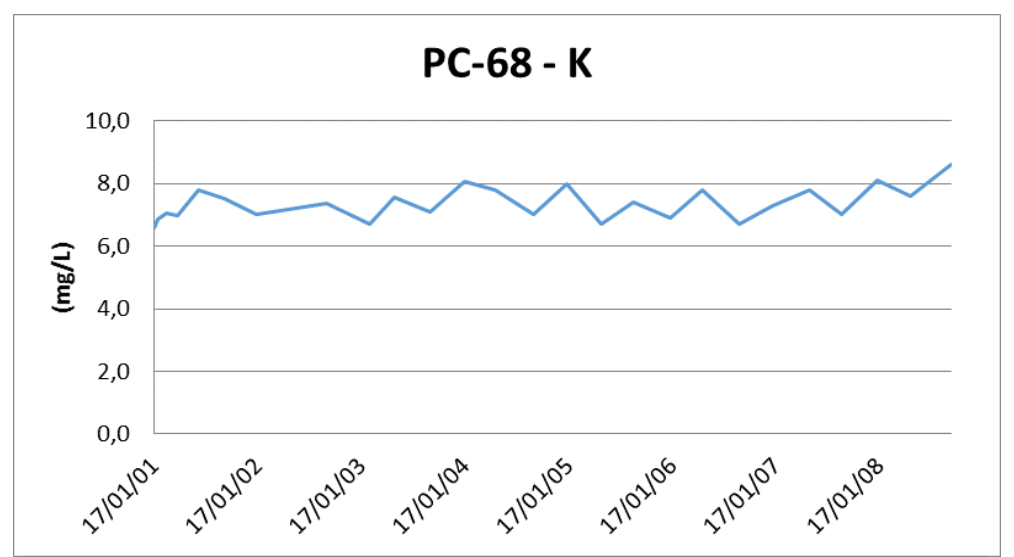

Figura 4.12 - Concentração de K no PC 68.

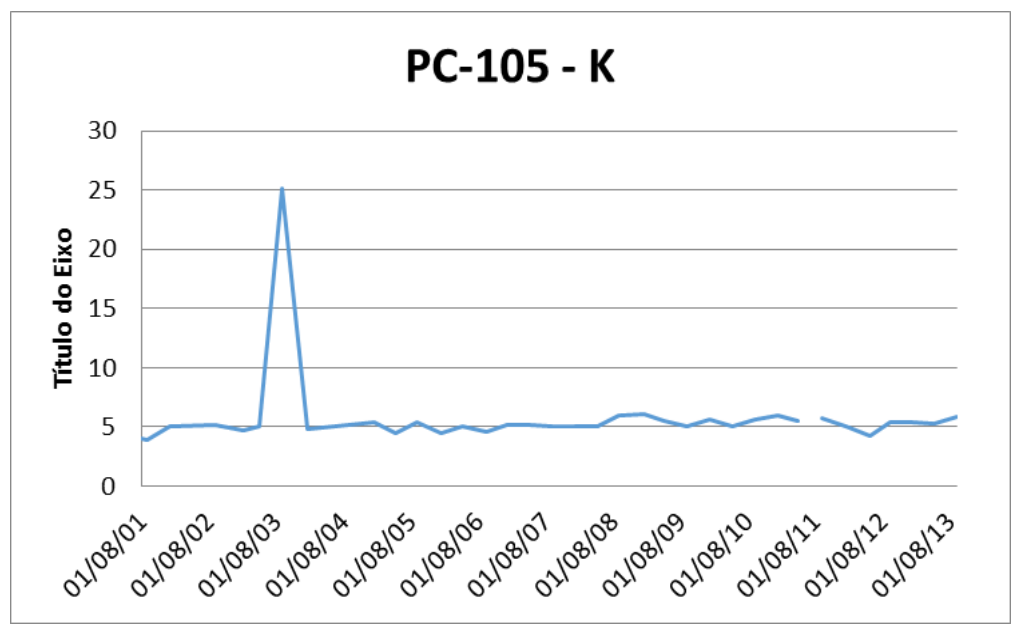

Figura 4.13 - Concentração de K no PC 105. 


\subsubsection{Distribuição do Ferro e Magnésio}

O ferro presente na água subterrânea tem sua origem relacionada aos minerais que possuem esse elemento em sua composição, tais como a magnetita, biotita, pirita, micas ferromagnesianas, piroxênio e anfibólios. Segundo Zimbres (2005) esse elemento pode existir nas valências +2 e +3 , sendo que a estabilidade de seus íons dependerá do $\mathrm{pH}$, Eh e da composição da solução. $\mathrm{Na}$ forma reduzida $\mathrm{Fe}^{+2}$ é solúvel e móvel. Já quando oxidado $\mathrm{Fe}^{+3}$ forma precipitados relativamente insolúveis, junto com carbonatos, sulfatos, óxidos e hidróxidos (Custódio \& LLamas, 1996). O magnésio pode ser oriundo da dissolução de biotita, anfibólios e minerais ferromagnesianos (piroxênios e olivinas). Considerando a geologia da área, no caso dos gnaisses, esses elementos originam-se preferencialmente dos piroxênios, biotitas e hematitas, resultado dos vários estágios de alteração metassomática.

Tanto no caso do $\mathrm{Fe}$, quanto do $\mathrm{Mg}$, as concentrações nas águas subterrâneas são maiores nos gnaisses e granito, quando comparadas aquelas observadas nos poços fora destes tipos petrográficos. Na figura 4.14 encontram-se os poços externos a área do Complexo da INB, com predomínio derochas quartzíticas e metapiroclásticas (Metariolito, Metadacito), já na figura 4.15 os poços encontram-se em gnaisses e granitos, dendro da área da INB. Além disso, os valores anômalos (outliers) também são constatados nestes dois primeiros conjuntos de rochas.

Como se verifica nos Box-Plots que se seguem, a maior parte dos poços em gnaisses e granitos encontra-se impróprios para consumo humano, em virtude das altas concentrações de ferro que, embora seja resultante da geologia da área, inviabilizam o uso dessas águas para fins de consumo humano (Figura 4.15).

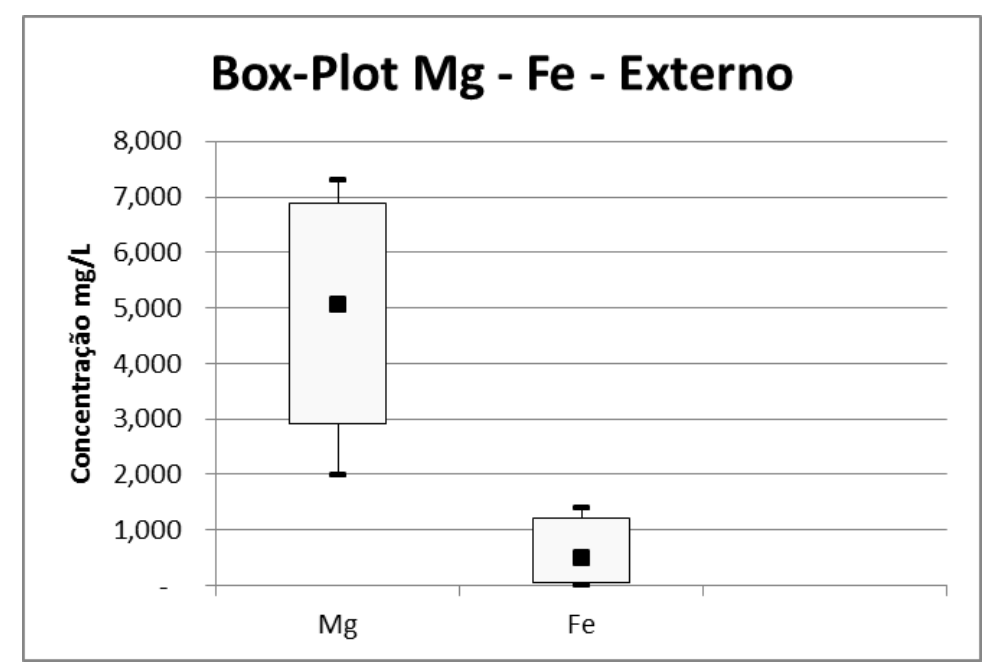

Figura 4.14 - Box-Plot da distribuição média da concentração de Fe e Mg nas águas subterrâneas de poços externos às áreas de lavra. 


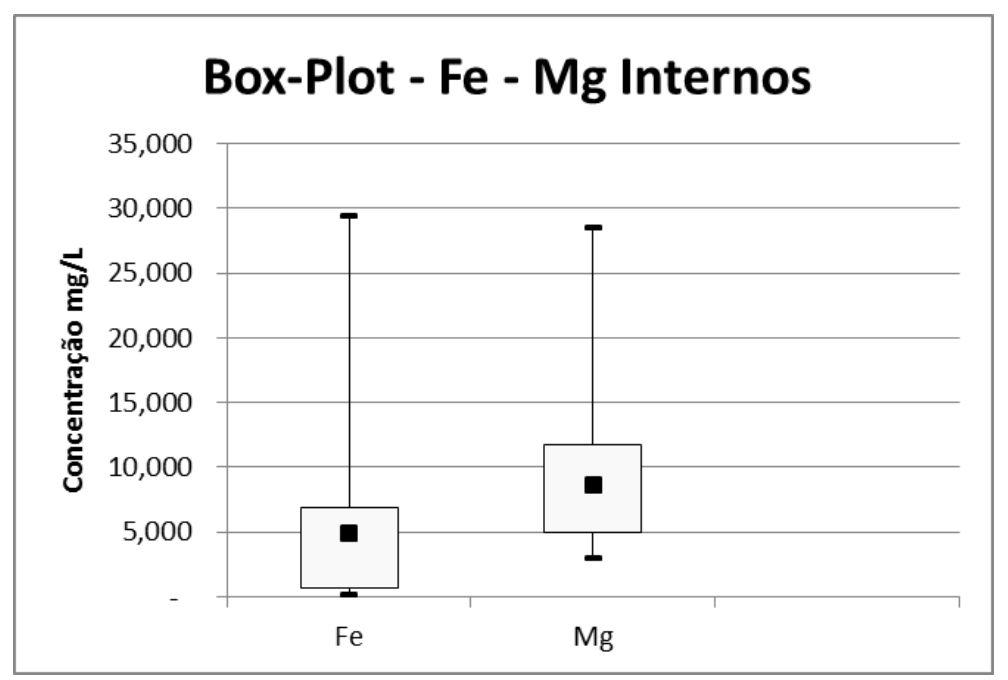

Figura 4.15 - Box-Plot da distribuição média da concentração de Fe e Mg nas águas subterrâneas em poços construídos nos domínios das áreas de lavra e beneficiamento.

\subsubsection{Distribuição do Manganês}

Assemelha-se ao ferro quimicamente, em termos de ocorrência nas águas subterrâneas, porém, em concentrações muito inferiores, em geral menores que $0,2 \mathrm{mg} / \mathrm{L}$ nas águas naturais (Feitosa \& Filho, 2000).

$\mathrm{Na}$ área de estudo, o teor médio do manganês nas águas é baixo (Figura 4.16). Apenas um poço apresenta valor médio acima de $1 \mathrm{mg} / \mathrm{L}$, o PC 23 perfurado em rocha gnáissica, localizado no fundo do vale onde corre o Riacho das Vacas (Anexo 01).

Esses teores baixos podem resultar do pH encontrado nessas águas, cujo valor médio mostra neutralidade ( $\mathrm{pH}$ médio igual a 7,1) na maior parte dos pontos avaliados. Quando, em ambiente oxidante, o pH for neutro ou levemente alcalino, espera-se que o manganês se precipite como óxido ou hidróxido.

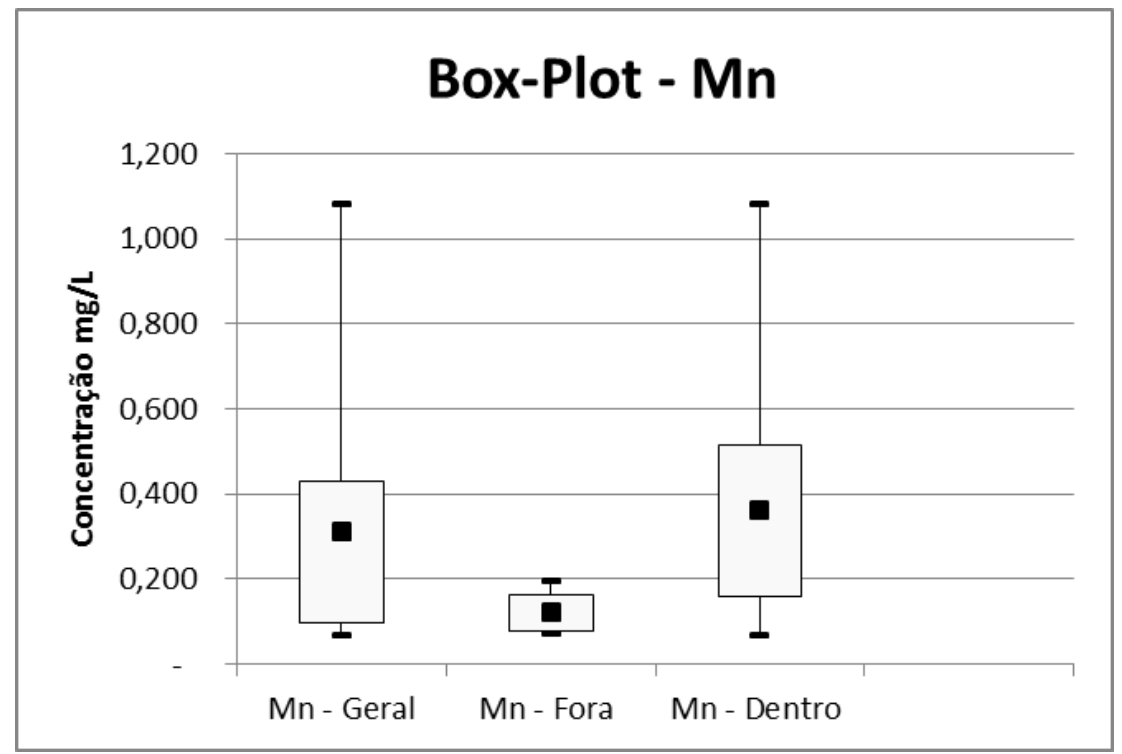

Figura 4.16 - Box-Plot da distribuição média da concentração de manganês nas águas subterrâneas em poços situados no interior e fora das áreas de mineração. 
Dentro da área do complexo da INB os valores médios de Mn encontrados nas amostras avaliadas variam de $0,06 \mathrm{mg} / \mathrm{L}$ a $1,07 \mathrm{mg} / \mathrm{L}$, com média de $0,36 \mathrm{mg} / \mathrm{L}$. Já fora desta região, os valores desse metal apresentam concentração média de $0,12 \mathrm{mg} / \mathrm{L}$.

\subsubsection{Distribuição do $\mathrm{SO}_{4}$}

Naturalmente o sulfato forma sais moderadamente a muito solúveis, exceto no caso dos sulfatos de estrôncio e de bário. A presença desse ânion nas águas resulta da oxidação de sulfetos das rochas, e da lixiviação de compostos sulfatados como gipsita e anidrita. As águas subterrâneas apresentam teores de sulfato, geralmente, inferiores a $50 \mathrm{mg} / \mathrm{L}$ (Feitosa \& Filho, 2000).

Na região estudada, sua distribuição nos aquíferos evidencia que, nas rochas gnáissicas e graníticas os valores são 16,6 vezes maiores do que nas rochas quartzíticas e metapiroclásticas (Figura 4.17). No PC 68 ocorre o maior valor observado de sulfato nas águas subterrâneas.

O sulfato encontrado dentro da área da INB se relaciona com as rochas gnáissicas e graníticas, já aquele amostrado fora dos domínios da mineradora referem-se às rochas quartzíticas e metapiroclásticas. No caso da distribuição de sulfato geral, dentro desta designação estão todos os diversos litotipos, considerando todos os poços analisados.

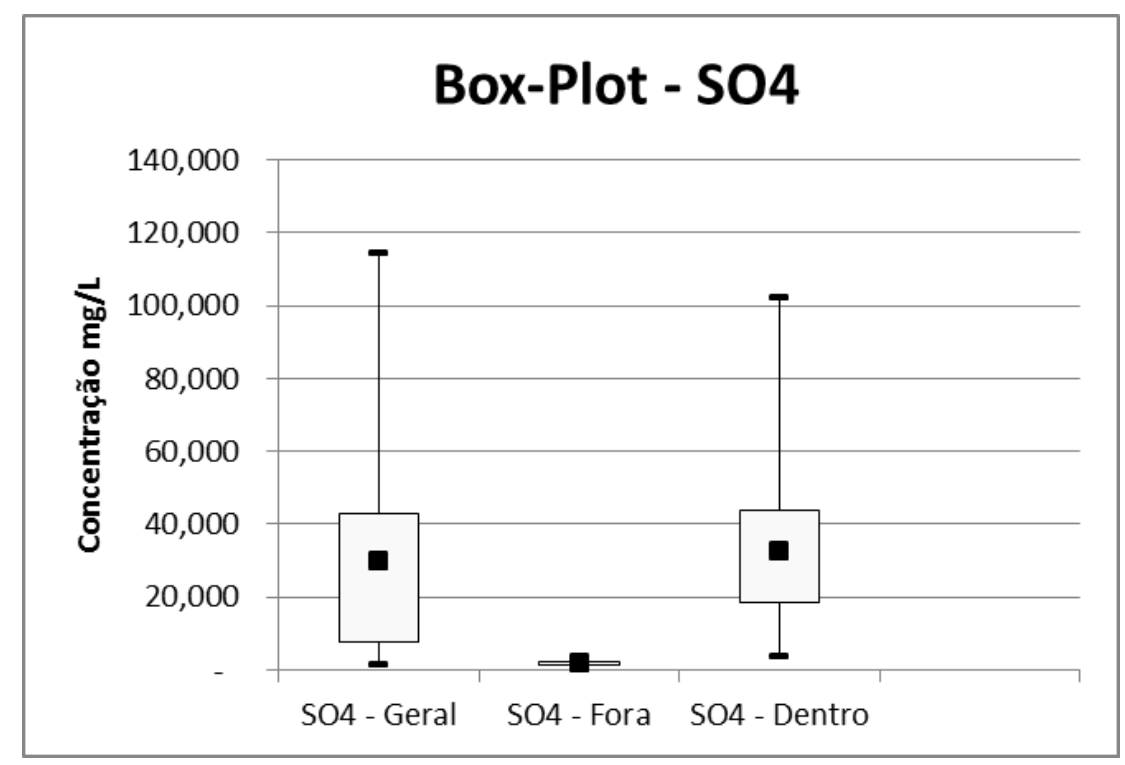

Figura 4.17 - Box-Plot da distribuição média da concentração de sulfato nas águas subterrâneas.

A partir da comparação dos mesmos poços já considerados anteriormente, para caracterização das águas subterrâneas (PC 18, PC 68 e PC 105), que refletem a variação da concentração dos parâmetros nessas águas, no que se refere a poços instalados em rochas de tipos petrográficos distintos, optou-se por agrupar o sulfato, o cálcio e o sódio, com o intuito de visualizar em conjunto essas diferenças (Figuras 4.18, 4.19 e 4.20). 
De acordo com os resultados que seguem, nos gnaisses (PC- 68) a concentração de $\mathrm{SO}_{4}$ e Na encontra-se mais elevada em comparação aos granitos (PC-18). Já o cálcio apresenta-se mais elevado nos granitos, em comparação aos gnaisses. Entretanto, quando se confronta essas duas rochas, com o quartzito representado pelo poço PC 105, as concentrações de cálcio, sulfato e sódio são 7,9, 17 e 17,2 vezes maiores, respectivamente, em relação aos outros dois poços.

A presença do ânion sulfato nas águas da região é atribuída à oxidação de fases minerais sulfetadas, principalmente a pirita que é ocasionalmente observada em amostras de mão de rochas recuperadas das cavas.

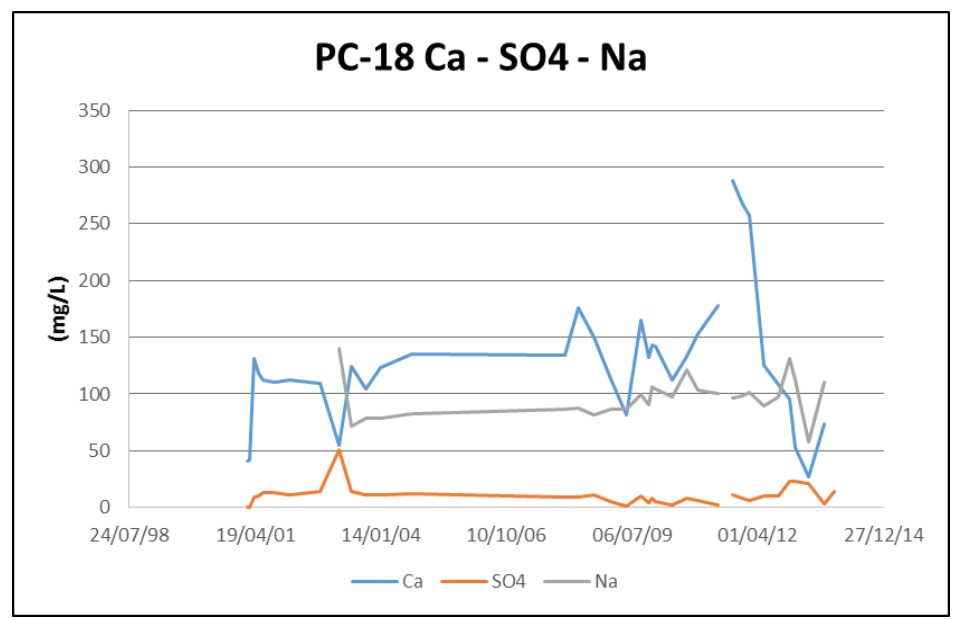

Figura 4.18 - Concentração de $\mathrm{Ca}, \mathrm{SO}_{4}$ e $\mathrm{Na}$ em águas do poço $\mathrm{PC}$ - 18.

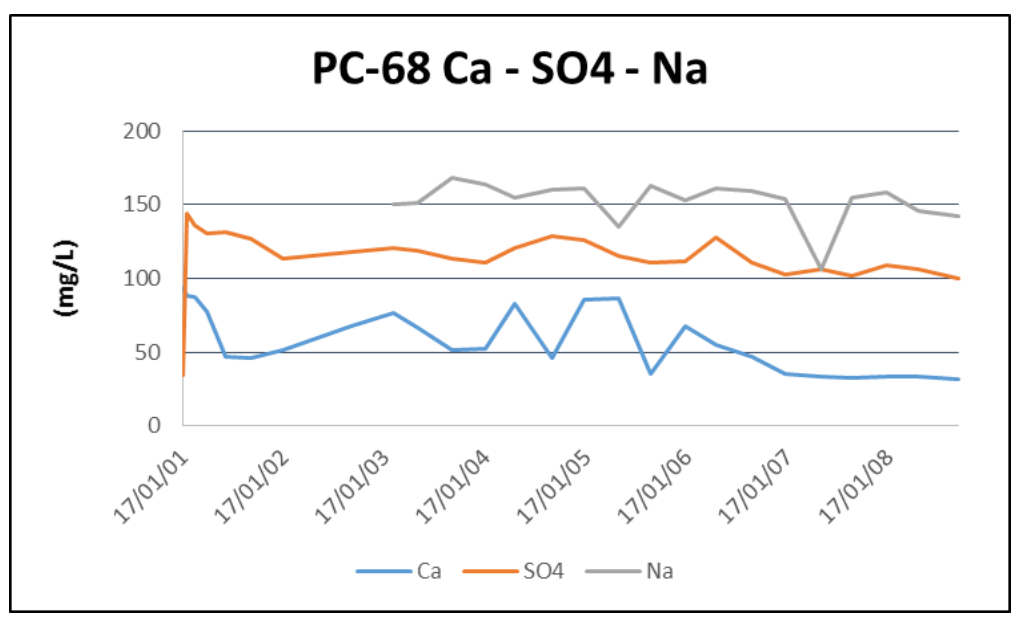

Figura 4.19 - Concentração de $\mathrm{Ca}, \mathrm{SO}_{4}$ e $\mathrm{Na}$ em amostras de água do poço PC - 68. 


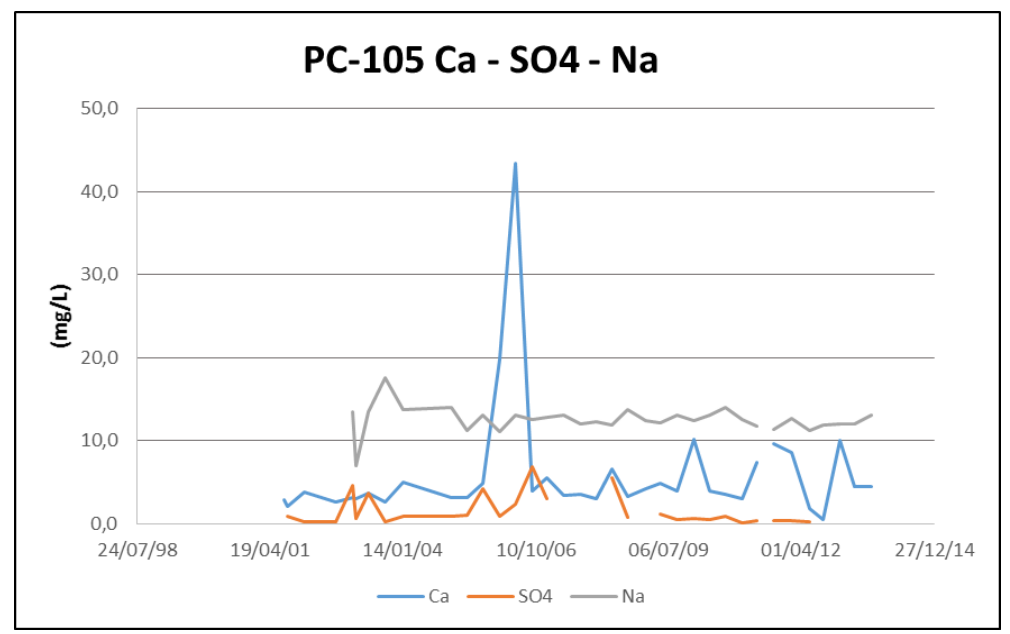

Figura 4.20 - Concentração de $\mathrm{Ca}, \mathrm{SO}_{4}$ e $\mathrm{Na}$ em amostras do poço PC - 105.

\subsubsection{Distribuição do Cloreto}

O cloreto pode ser considerado um dos principais responsáveis pela salinidade da água, e pode ser encontrado em todos os corpos hídricos superficiais ou subterrâneos. De acordo com Hem (1985), os sais de $\mathrm{Cl}^{-}$têm como característica serem solúveis e apresentarem estabilidade, quando em solução. Está presente em todas as águas naturais, com valores situados entre $10 \mathrm{e}$ $250 \mathrm{mg} / \mathrm{L}$ nas águas doces. Dificilmente precipita e normalmente não oxida nem se reduz em águas naturais (Feitosa \& Filho, 2000).

$\mathrm{Na}$ área de estudo observam-se elevadas concentrações de cloretos nas águas dos poços localizados em rochas graníticas e gnáissicas. Enquanto que, nos poços que captam água em quartzitos e rochas metapiroclásticas, a concentração média é de 15,70 mg/L, nos gnaisses e granitos essa concentração média se eleva para 198,2 mg/L, e esses valores altos podem ser encontrados tanto dentro da área do complexo da INB, quanto fora. Essa diferença nas concentrações de cloreto está essencialmente ligada a composição química do Granito São Timóteo e dos gnaisses que existem na região, em comparação com o quartzito.

Além de uma provável fonte a partir dos granitos e gnaisses que ocorrem na região, outra importante fonte para o cloreto refere-se àquela proveniente da atmosfera, a partir das águas de precipitação pluvial, como veremos mais adiante.

A Figura 4.21 mostra a variação da concentração de cloreto, geral, fora das áreas de ocorrência dos gnaisses e granitos e no interior do domínio destas rochas. 


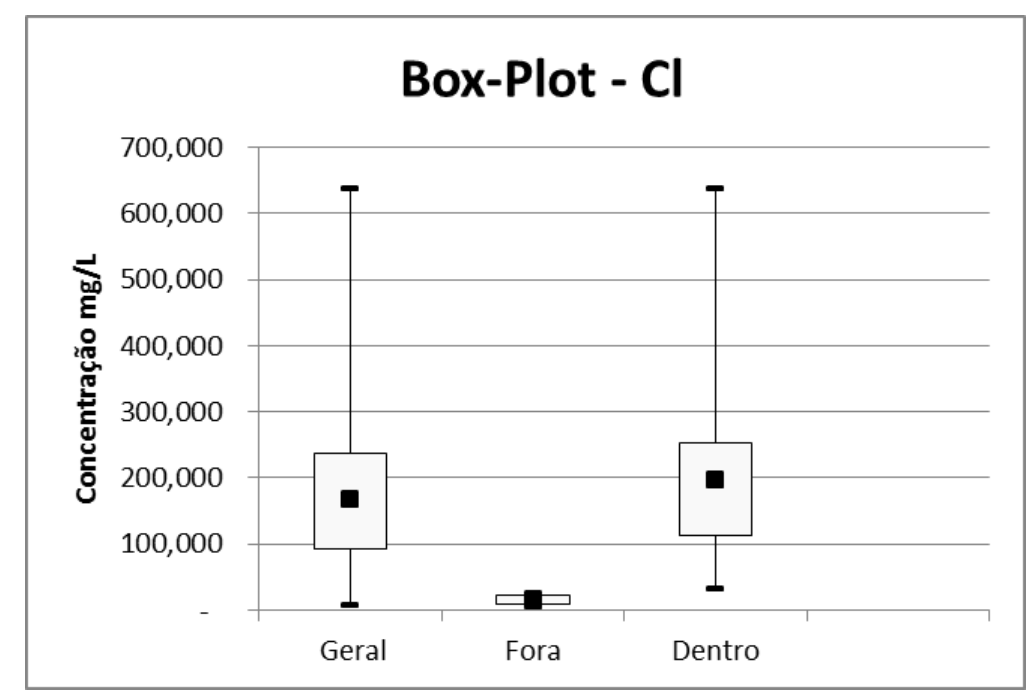

Figura 4.21 - Concentração do Cloreto considerando todos os poços construídos fora do domínio das rochas graníticas e gnáissicas e dentro deste conjunto de rochas.

Existem muitas opiniões em relação ao regime de salinização das águas subterrâneas no semiárido brasileiro. Alguns autores atribuem essa salinidade ao processo de dissolução dos minerais das rochas, em consequência da percolação das águas, através das descontinuidades da rocha (Teixeira \& Oliveira, 1962; Costa, 1965; Siqueira, 1963); outros atribuem a salinização das águas ao transporte de aerossóis, provenientes do mar, nas correntes atmosféricas (Rebouças, 1973; Matsui, 1978, apud Santos et al., 1984); para um terceiro grupo de pesquisadores, esse enriquecimento de sais nas águas subterrâneas está diretamente relacionado ao clima da região, que resulta num processo de salinização progressiva, da seguinte forma: precipitação - saturação do solo - evaporação - infiltração de uma solução mais concentrada nas chuvas posteriores (Cruz \& Mello, 1968, apud Santos et al., 1984).

Neste caso analisado perceber-se que o tempo de residência das águas em contato com as rochas, aliado ao fator climático podem ser considerados determinantes para as concentrações de cloreto diagnosticadas. A Figura 4.21 mostra a influência dos diferentes tipos de rochas e as concentrações de Cloreto em solução nas águas subterrâneas.

Dentre as análises químicas estudadas para caracterizar o aquífero, um poço se destacou com valores anômalos bastante elevados para cloro, bem como enriquecimento em sais, de modo geral. Este foi o PC - 113, que tem 64 metros de profundidade, instalado em rocha gnáissica (Figura 4.22). 


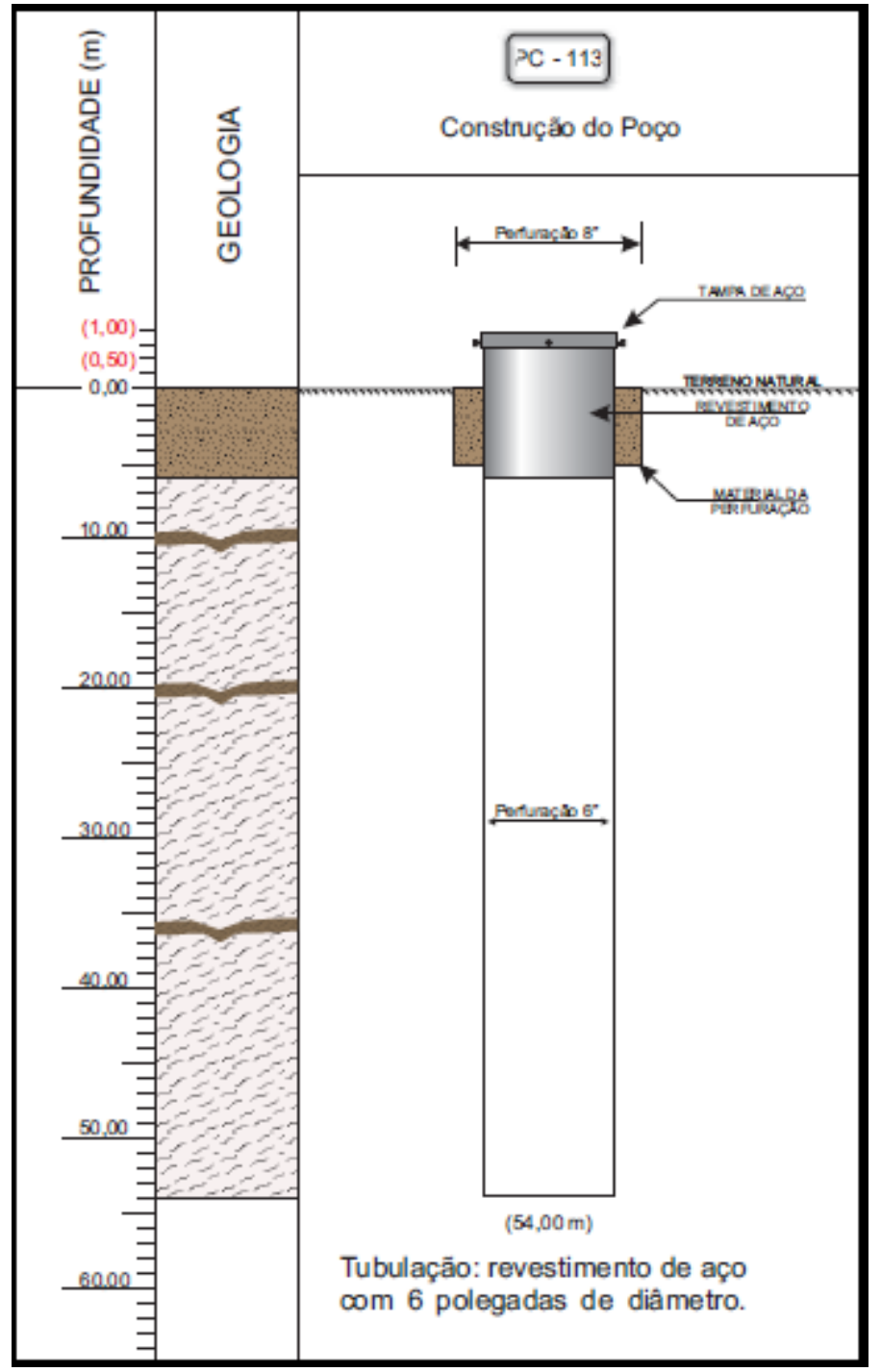

Figura 4.22 - Perfil construtivo do PC - 113, construído em rocha gnáissica, com entradas de água (zonas fraturadas) em 10, 20 e 36 metros de profundidade. As três linhas horizontais na cor marrom, observadas no perfil, representam as descontinuidades que este poço atravessou.

Este poço situa-se no vale do Córrego Cachoeira (Anexo 01), a jusante da cava da mina. Entre ele e as cavas ainda existem os poços: PC-01 (gnaisse), PC- 07 e PC-19, ambos perfurados em rocha granítica, segundo seus respectivos perfis construtivos. De acordo com os gráficos, baseados nos dados de monitoramentos dos parâmetros físico-químicos já descritos (Figuras 4.23, 4.24 e 4.25), constata-se que existe significativo aumento da concentração de $\mathrm{Cl}$, $\mathrm{Na}, \mathrm{Mg}, \mathrm{Ca}, \mathrm{SO}_{4}$ e Ba no poço PC- 113, a partir do primeiro semestre de 2008. No PC-01, o primeiro poço instalado a jusante das cavas, não se verifica esse mesmo enriquecimento no mesmo período. Da mesma forma, os poços situados a jusante, não demonstram comportamento semelhante, o que dificulta o estabelecimento de uma possível ligação dessas concentrações com a eventual contaminação dessas águas. 


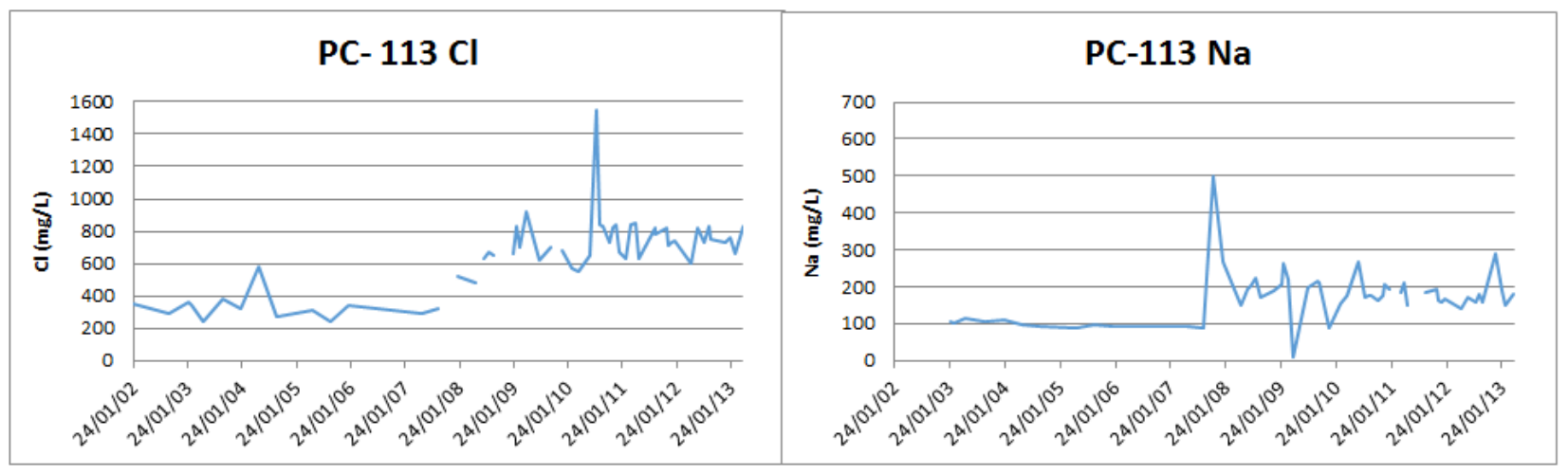

Figura 4.23 - Concentração de cloro e sódio no PC - 113.

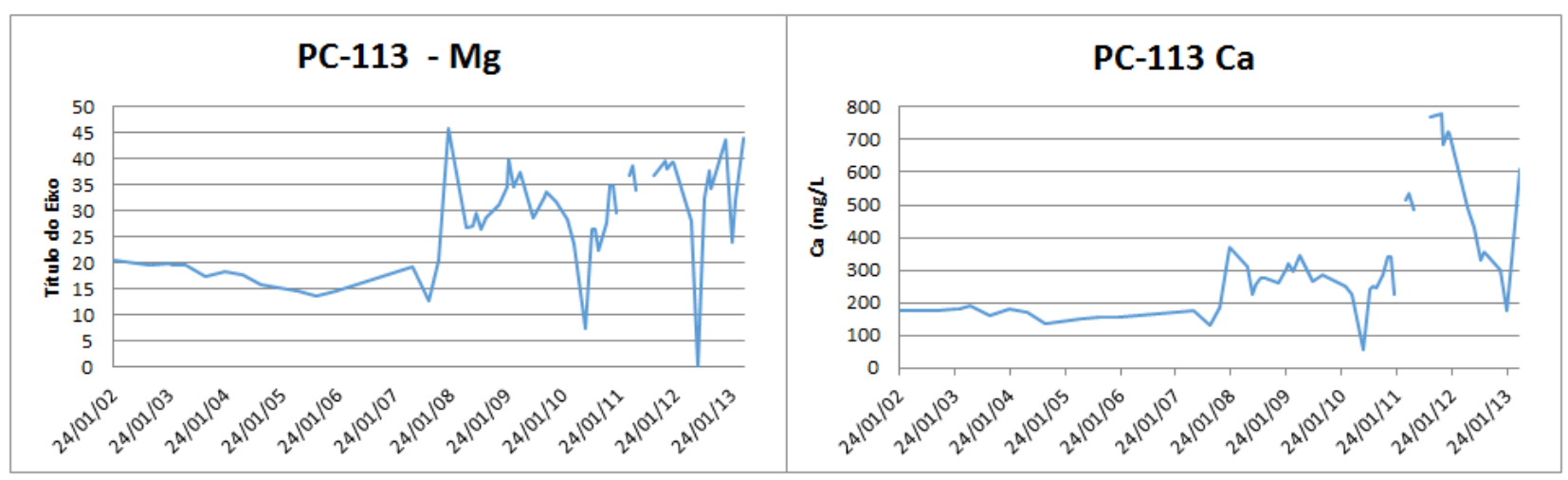

Figura 4.24 - Concentração de magnésio e cálcio no PC - 113.

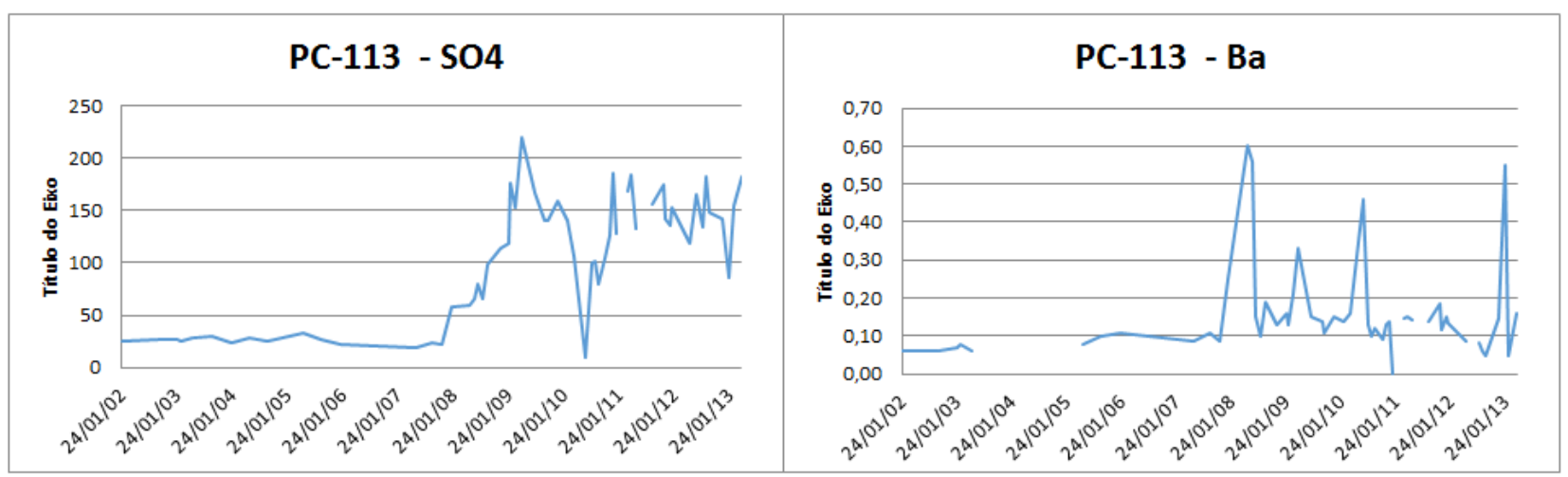

Figura 4.25 - Concentração de sulfato e bário no PC - 113.

De acordo com Zhu \& Sverjensky (1992) o cloreto pode ter origem geogênica a partir da substituição de $\mathrm{OH}$ por $\mathrm{Cl}$ em alguns filossilicatos (particularmente a biotita), podem ser naturalmente enriquecidos nesse elemento. Este cloreto pode ser colocado em solução, em função das interações água-rocha, por troca iônica ou adsorção quando, por exemplo, a biotita, se altera formando outros minerais. Considerando a descrição da geologia local, sabe-se que na área existem importantes zonas de cisalhamento, onde ocorre enriquecimento em minerais máficos, inclusive com a ocorrência de biotitito. Essas áreas são consideradas importantes zonas de recarga do aquífero, e também são mais facilmente afetadas pelo intemperismo químico, ocorrendo geração de argilominerais como resultado da alteração da rocha. Assim, 
parte do cloro observado é considerada como proveniente da alteração dos minerais máficos enriquecidos nas zonas de cisalhamento.

Especialmente no caso do PC - 113 instalado em rocha gnáissica, as concentrações observadas indicam que este poço tenha interceptado área com bolsão carbonático (que ocorre com frequência em toda a região), devido aos altos teores de $\mathrm{Ca}$, atípicos para águas subterrâneas de aquíferos gnáissicos. Por não se observar este mesmo comportamento nos poços vizinhos, conclui-se que não existem descontinuidades comunicando essas águas com aquelas captadas nos demais poços, o que resulta em uma região localmente isolada, onde o teor de alguns elementos encontra-se mais elevado, em consequência da mineralogia do reservatório nesta área, bem como, da influência do clima semiárido no condicionamento da concentração, maior, de total de sais dissolvidos.

\subsubsection{Distribuições da Sílica e Alumínio}

O intemperismo de minerais de argila e os feldspatos constituem as principais fontes de sílica para as águas subterrâneas. O quartzo também é uma importante fonte potencial de sílica, porém, possui forte resistência ao ataque do intemperismo. Teores de $20 \mathrm{mg} / \mathrm{L}$ nas águas subterrâneas não são raros (Feitosa \& Filho, 2000).

De acordo com Cetesb (2009), o alumínio pode ocorrer em diferentes formas nas águas, e é influenciado pelo $\mathrm{pH}$, temperatura e presença de fluoretos, sulfatos, matéria orgânica e outros ligantes. A solubilidade é baixa em pH entre 5,5 e 6,0. As concentrações de alumínio dissolvido em águas com $\mathrm{pH}$ neutro variam de 0,001 a 0,05 mg/L, mas aumentam para 0,5 a 1 $\mathrm{mg} / \mathrm{L}$ em águas mais ácidas ou ricas em matéria orgânica. Em águas com extrema acidez, afetadas por descargas de mineração, as concentrações de alumínio dissolvido podem ser maiores que $90 \mathrm{mg} / \mathrm{L}$.

As análises químicas mostram que, dentro da área do complexo da INB, os teores de sílica são maiores que nos demais poços amostrados (Figura 4.26). Considerando que dentro do complexo predominam rochas graníticas e gnáissicas e, à exceção do PC - 68 (incluído fora da área neste caso), todos os demais poços investigados nesta tese encontram-se em quartzitos ou em rochas metapiroclásticas, percebe-se que há um controle geológico na quantidade de sílica encontrada nas águas subterrâneas da região. Ainda que, a exemplo do PC- 115, alguns poços encontrem-se em quartzito, o quartzo que representa o principal mineral constituinte da rocha é mais resistente ao intemperismo quando comparado, por exemplo, aos cristais de albita e demais silicatos que constituem parte da mineralogia, tanto do granito, quanto dos gnaisses que ocorrem dentro da área do complexo mínero-industrial. 


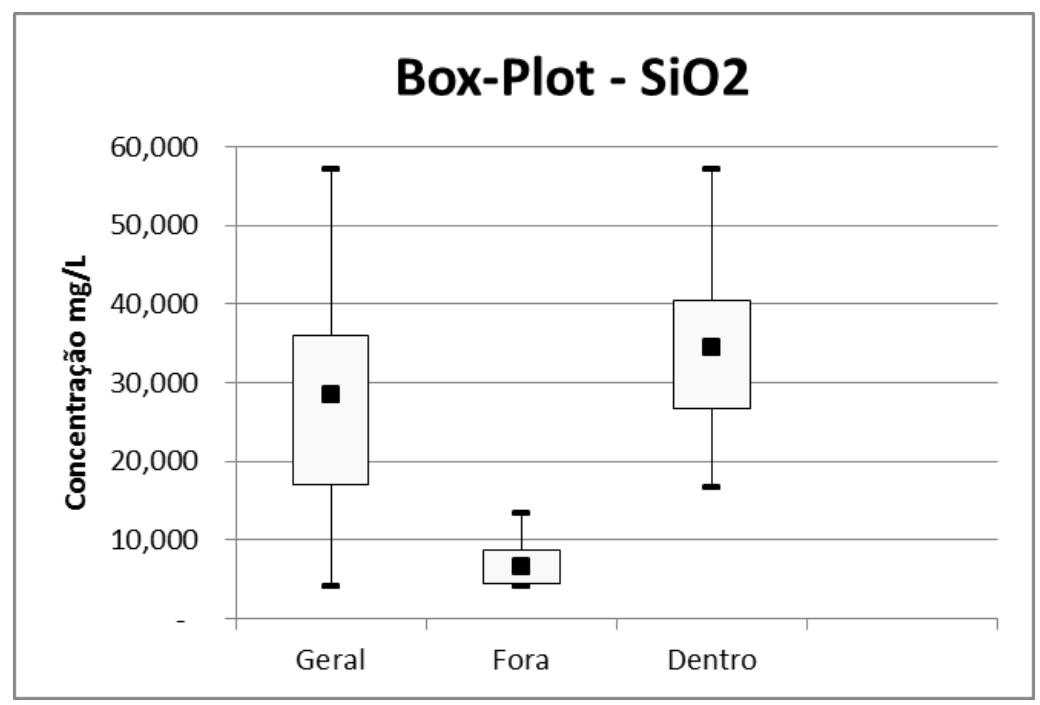

Figura 4.26 - Concentração de sílica nas águas amostradas, dentro da área do complexo e nas demais regiões onde existem poços para captação de água subterrânea.

No caso do alumínio, a concentração média observada dentro da área foi 0,44 mg/L, com anomalia de 2,24 mg/L no PC - 32, que se localiza a norte do Riacho das Vacas, em rocha granítica, bastante fraturada, porém, cujas descontinuidades foram diagnosticadas até a profundidade de 27 metros. Já fora da área do Complexo da INB, o teor médio de Al nos poços foi $0,41 \mathrm{mg} / \mathrm{L}$ (Figura 4.27 ).

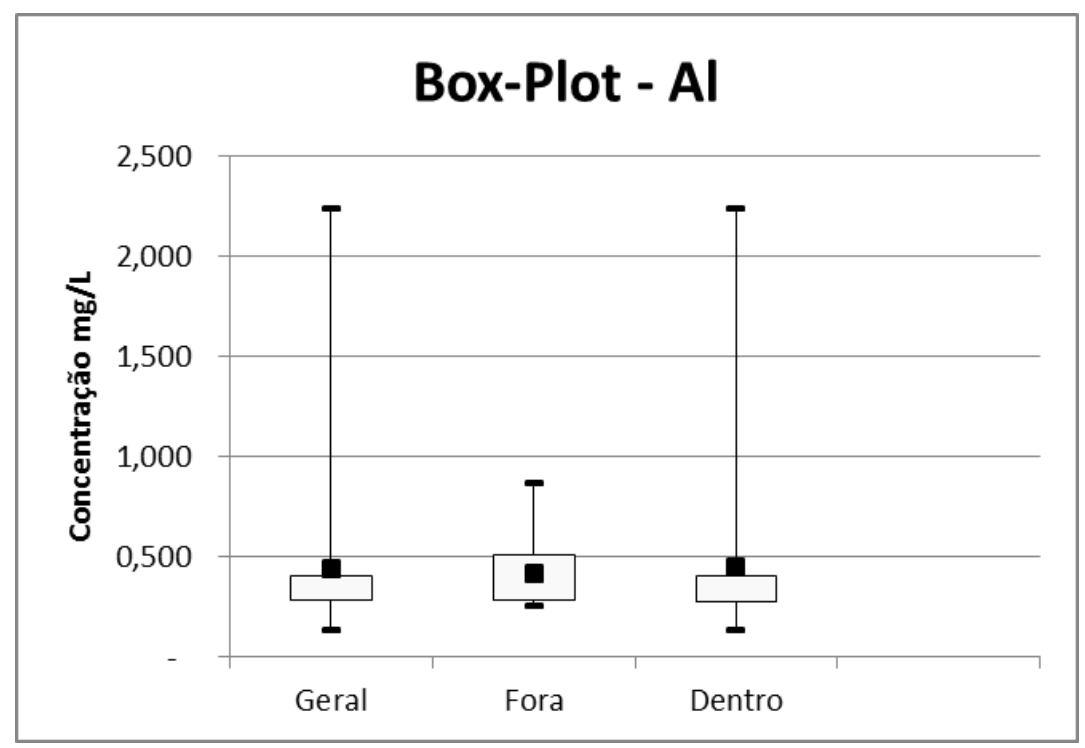

Figura 4.27 - Concentração de alumínio nas águas amostradas, dentro da área do complexo e nas demais regiões onde existem poços para captação de água subterrânea.

\subsubsection{Distribuição do Nitrato e Nitrito}

As fontes de nitrogênio nas águas naturais são diversas. Os esgotos sanitários constituem, em geral, a principal fonte (Cetesb, 2009). Teores de nitrato acima de $2 \mathrm{mg} / \mathrm{L}$ podem ser indicativos de contaminação da água subterrânea por atividade humana (esgotos, fossas sépticas, depósitos de lixo, cemitérios, adubos nitrogenados, resíduos de animais, etc.). Esses 
resíduos ricos em nitrogênio se decompõem em nitrato, na presença de oxigênio. Já a presença de nitrito na água subterrânea é um indicativo de poluição recente ou com fonte próxima a área de sua detecção (Feitosa \& Filho, 2000).

As concentrações de nitrato encontradas na região analisada apresentam-se elevadas, indicando contaminação antrópica, possivelmente de dejetos de animais (principalmente) e lançamento de esgoto sanitário através de fossas, sem tratamento (subordinadamente). Inclusive, fora da área do complexo da INB essas concentrações apresentam-se mais elevadas, tanto para nitrato quanto para nitrito (Figuras 4.28 e 4.29), onde se desenvolve criação de animais e as construções são precárias, sem rede pública de água e esgotamento sanitário.

Embora não seja foco da presente pesquisa, os teores de nitrato refletem um importante problema ambiental na região, considerando que os poços amostrados revelam contaminação das águas subterrâneas por $\mathrm{NO}_{3}$, em concentrações bastante altas.

Por outro lado, os baixos teores de nitrito indicam que as fontes de nitrogênio são antigas e praticamente totalmente oxidadas quando ocupam os espaços porosos nos aquíferos.

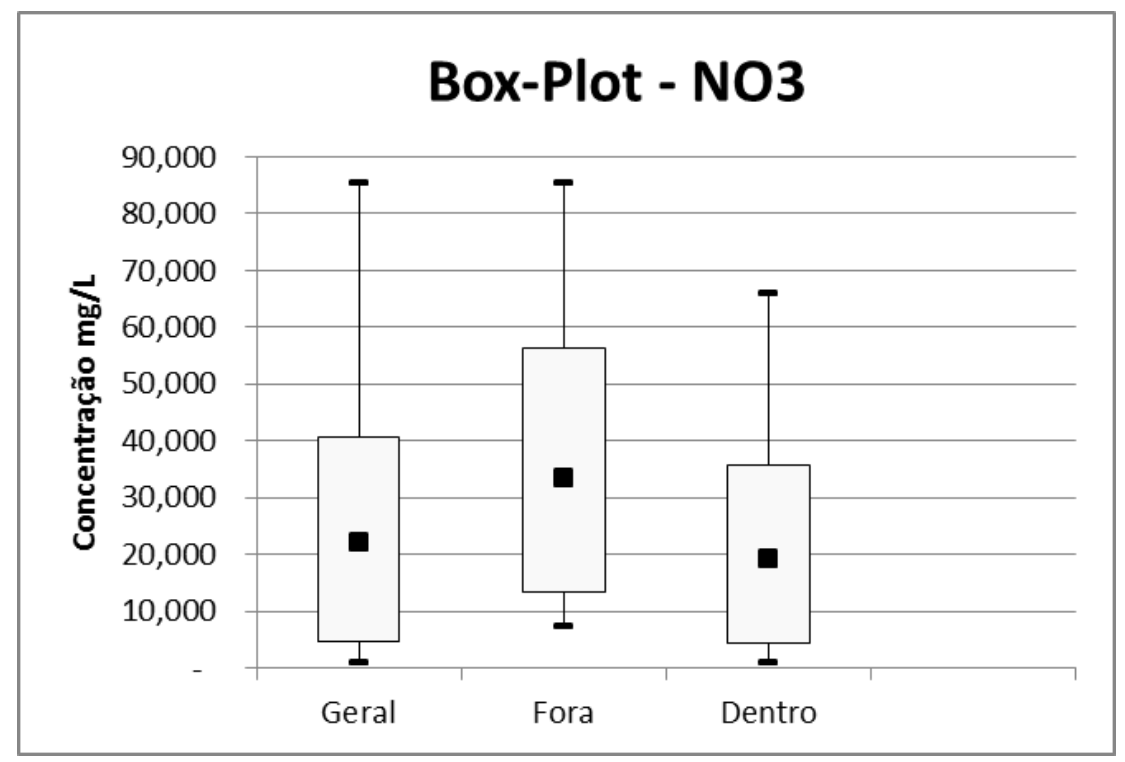

Figura 4.28 - Concentração de $\mathrm{NO}_{3}$ nas águas amostradas, dentro da área do complexo e nas demais regiões onde existem poços de captação de água subterrânea para abastecimento humano. 


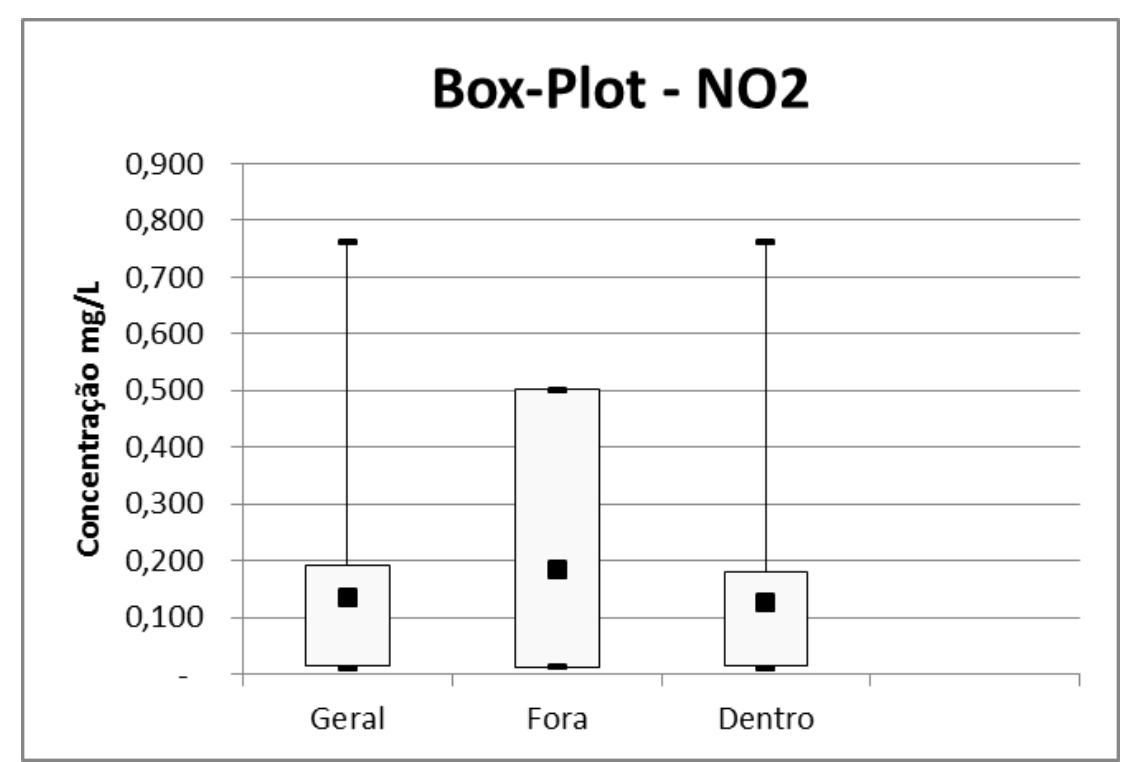

Figura 4.29 - Concentração de $\mathrm{NO}_{2}$ nas águas amostradas, dentro da área do complexo e nas demais regiões onde existem poços para captação de água subterrânea.

\subsubsection{Distribuição do Bário, Fósforo, Flúor e Molibdênio}

O bário corre naturalmente na água, na forma de carbonatos em algumas fontes minerais, geralmente em concentrações entre 0,007 e 0,9 mg/L (Cetesb, 2009).

A presença de fósforo na água está relacionada a processos naturais (dissolução de rochas, decomposição de matéria orgânica, chuva) ou antropogênicos (lançamentos de esgotos, detergentes, fertilizantes e pesticidas). Em águas não poluídas, as concentrações de fósforo encontram-se entre 0,01 a 0,05 mg/L. Valores acima de 1,0 mg/L geralmente são indicativos de águas poluídas. A presença de fósforo na água indica contaminação por fertilizantes, detergentes, efluentes domésticos, inseticidas e pesticidas (Feitosa \& Filho, 2000). Entretanto, de acordo com Nascimento \& Barbosa (2005), o fosfato não é tão preocupante quanto o nitrato, porque é menos móvel na água e, consequentemente, mais facilmente absorvido pela fração sólida do aquífero, atenuando sua influência como contaminante.

O fluoreto é o mais eletronegativo de todos os elementos químicos. É tão reativo que nunca é encontrado em sua forma elementar na natureza, sendo normalmente encontrado como sal de fluoreto. Nas rochas, esse elemento ocorre, principalmente, na forma de fluorita $\left(\mathrm{CaF}_{2}\right)$, fluoroapatita $\left(\mathrm{F}_{10}\left(\mathrm{PO}_{4}\right)_{6}\right)$ e criolita $\left(\mathrm{Na}_{3} \mathrm{AlF}_{6}\right)$. Em locais onde existem minerais ricos em flúor as concentrações podem chegar a $10 \mathrm{mg} / \mathrm{L}$. A maior concentração de flúor registrada em águas naturais é de $2.800 \mathrm{mg} / \mathrm{L}$, no Quênia (Cetesb, 2009).

O molibdênio não participa de forma efetiva na formação de minerais essenciais de rocha durante a cristalização magmática. Porém, pode apresentar enriquecimento em rochas ígneas ácidas e, sobretudo nas rochas graníticas que comportam concentrações da ordem de 1,5 mg/L. Em rochas máficas e ultramáficas a concentração média cai para valores sempre inferiores a 1 mg/L (Kabata Pendías \& Pendiás, 1984; Siegel, 1979).

De acordo com as análises químicas das águas dos poços, os teores de bário 
apresentam-se dentro da faixa de variação descrita por Cetesb (2009), onde o valor médio (considerando todos os poços), foi de $0,18 \mathrm{mg} / \mathrm{L}$. Considerando a abundância de cálcio nas águas analisadas, espera-se que o teor de bário em solução seja baixo, em razão da precipitação deste elemento em forma de carbonato de bário. No caso do fósforo, os valores encontrados estão baixos, com média de $0,09 \mathrm{mg} / \mathrm{L}$. Em relação ao flúor, nota-se quantidade média relativamente elevada em solução, valores bem distribuídos, com média de 1,78 mg/L. Finalmente, no que se refere ao molibdênio, a concentração média observada foi de $0,17 \mathrm{mg} / \mathrm{L}$ (Figura 4.30).

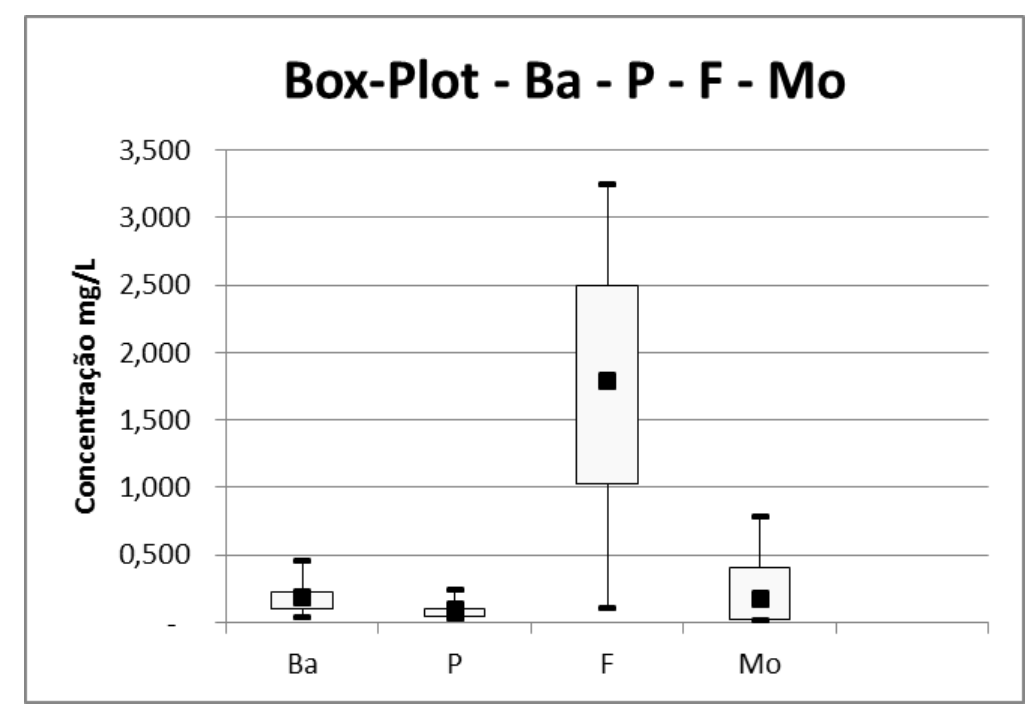

Figura 4.30 - Concentrações de Ba, P, F e Mo nas águas amostradas, considerando todos os poços.

\subsubsection{Distribuição do $T h,{ }^{226} R a,{ }^{228} R a e^{210} \mathrm{~Pb}$}

Dentre os quatro isótopos de Ra que ocorrem naturalmente, o ${ }^{226} \mathrm{Ra}$ e o ${ }^{228} \mathrm{Ra}$ são os mais abundantes e mais radiotóxicos, devido as suas meias-vidas relativamente longas (Williams \& Kirchmann apud Jesus, 2010). Dentre os compostos insolúveis de Ra, o sulfato de rádio é o sal de rádio mais insolúvel que se conhece, inclusive, sendo usado no processo de recuperação de Ra.

A presença de rádio nos aquíferos resulta da interação água/solo/rocha, desde que ele faça parte da composição desses sólidos. De acordo com Jesus (2010), a ocorrência de rádio nas águas subterrâneas pode ser consequência de atividades antrópicas, mais especificamente, exploração de $U$ e Th. Isso se dá em virtude do rádio ser gerado através do decaimento radioativo de urânio e tório. O Ra-226 é um emissor alfa de meia-vida relativamente longa (1602 anos), formado a partir do decaimento radioativo sequencial de cinco isótopos radioativos: $U$ $238 \rightarrow$ Th-234 $\rightarrow \mathrm{Pa}-234 \rightarrow \mathrm{U}-234 \rightarrow \mathrm{Th}-230 \rightarrow \mathrm{Ra}-226$. O Ra-228 é um emissor beta, com meia-vida de 5,75 anos, formado diretamente a partir do decaimento do Th-232.

O tório é cerca de três a quatro vezes mais abundante na crosta terrestre que o urânio, por ser menos sujeito à mobilização no ambiente supérgeno (Gabelman apud Tonetto \& Bonotto, 
2002). Na natureza predomina a ocorrência como um cátion tetravalente. A torianita $\left(\mathrm{ThO}_{2}\right)$ e torita $\left(\mathrm{ThSiO}_{4}\right)$ são os principais minerais fonte de tório (Ivanovich \& Harmon apud Tonetto \& Bonotto, 2002).

Por ocorrer em minerais de difícil dissolução, em geral, o tório pode ser considerado bastante insolúvel em água. Entretanto, a formação de complexos inorgânicos com os íons $\mathrm{Cl}^{-}$, $\mathrm{NO}_{3}^{-}, \mathrm{H}_{3} \mathrm{PO}_{4}, \mathrm{H}_{2} \mathrm{PO}_{4}^{-}, \mathrm{SO}_{4}{ }^{2-}, \mathrm{F}^{-}, \mathrm{OH}^{-}$e $\mathrm{HPO}_{4}{ }^{2-}$ e orgânicos como oxalatos, citratos e ácido etilenodiamino tetracético (EDTA), contribui para que sua mobilidade seja favorecida no ambiente hídrico (Tonetto \& Bonotto, 2002).

$\mathrm{O}{ }^{210} \mathrm{~Pb}$ resulta do decaimento radioativo da série do U-238, é um emissor beta de meiavida de 21 anos. A mobilidade de chumbo no ambiente é bastante restrita, no entanto condições especiais como altas concentrações de ácidos húmicos em água podem ser responsáveis por elevar suas concentrações no meio aquoso.

$\mathrm{Na}$ área de estudo, a radioatividade média observada nos poços é baixa. De acordo com os dados, têm-se radiação média igual a: $0,081 \pm 0,0113 \mathrm{~Bq} / \mathrm{L}$ de ${ }^{226} \mathrm{Ra}, 0,151 \pm 0,0204 \mathrm{~Bq} / \mathrm{L}$ de ${ }^{228} \mathrm{Ra}, 0,00717 \pm 0,00159 \mathrm{~Bq} / \mathrm{L}$ de Th natural e $0,0937 \pm 0,0179 \mathrm{~Bq} / \mathrm{L}$ de ${ }^{210} \mathrm{~Pb}$. No caso do ${ }^{226} \mathrm{Ra}$ e do ${ }^{210} \mathrm{~Pb}$ principalmente, a média está deslocada, com valor mais alto, em função de valores anômalos. Sendo assim, a mediana representa melhor o valor onde a maior parte dos dados se concentra, que respectivamente é $0,110 \pm 0,015 \mathrm{~Bq} / \mathrm{L}$ e $0,067 \pm 0,016 \mathrm{~Bq} / \mathrm{L}$ para o ${ }^{226} \mathrm{Ra}$ e para o ${ }^{210} \mathrm{~Pb}$ (Figura 4.31).

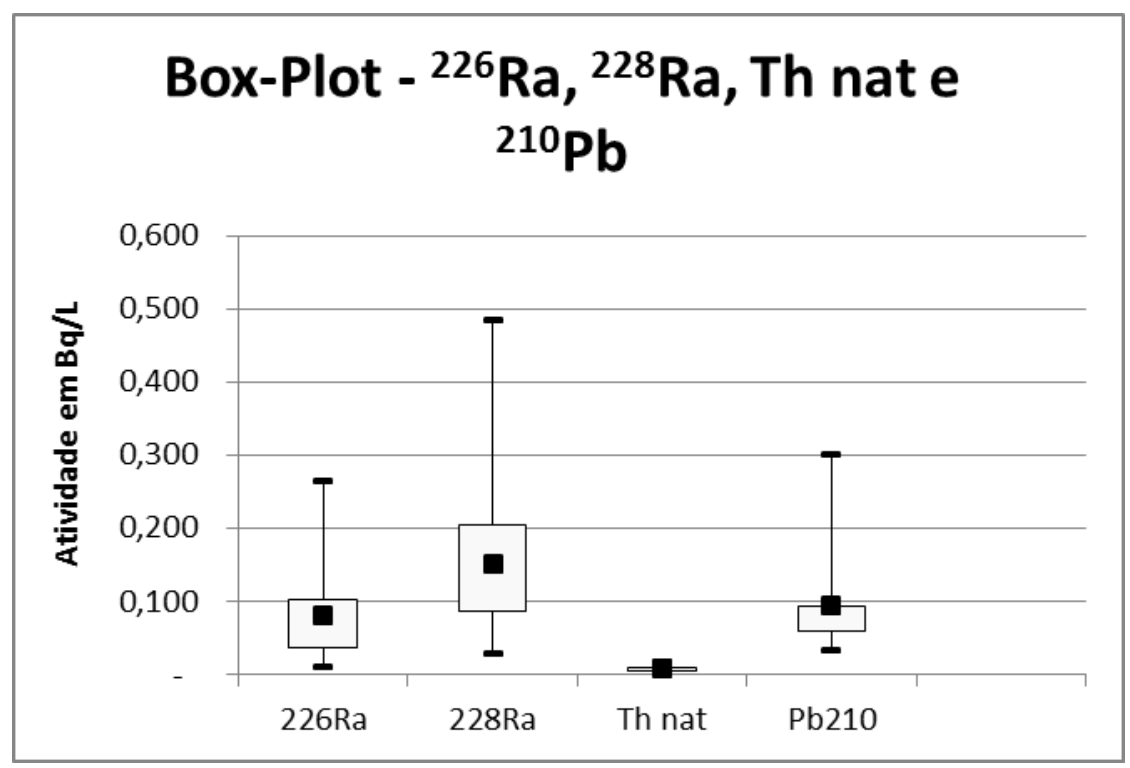

Figura 4.31 - Distribuição da radioatividade medida nas águas amostradas, considerando todos os poços, para ${ }^{226} \mathrm{Ra},{ }^{228} \mathrm{Ra}$, Th natural e ${ }^{210} \mathrm{~Pb}$.

Os valores baixos de radioatividade para o tório, nesse caso específico, indicam que esses isótopos não são formadores dos minerais encontrados nas rochas da região. Minerais hospedeiros de tório são altamente resistentes ao intemperismo e, portanto, o tório tem sido considerado como um elemento imóvel e insolúvel em águas naturais, como atestam dados da 
concentração de tório nestes ambientes, onde é encontrado em baixas concentrações, ou nem ocorre. Entretanto, a ocorrência de altos teores de cloro, nitrato e sulfato nas águas subterrâneas, favoreceria a formação de complexos inorgânicos com o tório, caso pudesse ser encontrado nas rochas da área. De fato, não há registro de anomalias de tório na região.

Já no que se refere aos isótopos de rádio, ${ }^{226} \mathrm{Ra}$ e ${ }^{228} \mathrm{Ra}$, dada a presença de altas concentrações de sulfato na água, espera-se que estes isótopos, quando em solução nas águas, precipitem sob a forma de sulfato de rádio, que é um sal bastante insolúvel.

Em se tratando do ${ }^{210} \mathrm{~Pb}$, a baixa radioatividade detectada corrobora com a baixa mobilidade que esse isótopo apresenta no meio aquoso.

\subsection{Determinação de valores de Background na Água Subterrânea}

Plumlee (1999) apoiado em estudos de exploração geoquímica, definiu o termo background como à concentração anômala de um elemento em um material sob investigação. Esse material pode ser rocha, solo, plantas ou água.

Já outros autores, como Matschullat et al. (2000), afirmaram não haver, até aquele momento, definição clara e precisa sobre este conceito. Sendo assim, o definiram como uma medida relativa, a ser utilizada na distinção entre as concentrações naturais de um dado elemento e as concentrações influenciadas por atividades antrópicas. Já Galuszka (2006) determinou o background como uma concentração teoricamente natural, de uma substância ou elemento em uma amostra, considerando as variáveis temporal e espacial da área sob investigação.

O conceito que melhor atende nossa aplicação de background para a área em estudo corresponde aquele definido por Galuszka (2006). Nesse sentido, em relação às concentrações dos parâmetros físico-químicos diagnosticadas nas águas, o background refere-se aos teores naturais, determinados pelo equilíbrio entre a composição das rochas e o clima da região, ao longo do tempo de contato entre a água e as rochas.

Essa determinação do background traz algumas implicações em relação aos radionuclídeos, especificamente no caso do urânio - alvo de muitos questionamentos. Neste caso, pode-se considerar se há contaminação, como resultado da atividade de mineração, ou se a influência das anomalias desse elemento nas rochas (inclusive formando depósitos economicamente viáveis para exploração), resulta em maiores concentrações naturais dissolvidas nas águas subterrâneas. Além dos radionuclídeos, o mesmo pode ser aplicado ao caso do nitrato, bem como alguns sais, a exemplo do cálcio, sódio, cloro e sulfato, que apresentam teores elevados. Nesse sentido, a determinação do background será aplicada para o $\mathrm{U}, \mathrm{Na}, \mathrm{Cl}, \mathrm{Ca}, \mathrm{SO}_{4}$ e $\mathrm{NO}_{3}$. Para o caso dos radionuclídeos os níveis de radioatividade estão expressos em Becquerel por litro $(\mathrm{Bq} / \mathrm{L})$.

A mina de urânio, situada dentro do Complexo Mínero-industrial da INB, no município de Caetité, teve início de suas operações em 1999. O primeiro poço para captação de água 
subterrânea foi o PC-01, perfurado em 1989, durante a fase de pesquisa da área. As análises químicas mais antigas, disponibilizadas pela INB datam de 1998. Nesse sentido, o estabelecimento dos valores de background dos parâmetros analisados baseou-se nas seguintes diretrizes:

a) Valores encontrados nas análises mais antigas - os resultados encontradas nas análises químicas das águas dos poços, principalmente aqueles perfurados antes da abertura e início das operações serviram de base para determinação das concentrações naturais, pretéritas as ações que expuseram a rocha a maior ação do intemperismo;

b) Análise estatística - considerando os poços perfurados dentro dos limites da área de propriedade da INB, bem como, poços perfurados a grandes distâncias, sendo a maior delas de, aproximadamente, 19,5 km. Nesses casos, considerou-se todo o histórico de análises para cada poço, ao longo dos anos. A partir daí calculou-se a média, mediana, máximos, mínimos, terceiro quartil e primeiro quartil. Com base nessas informações elaborou-se Box-Plots para cada parâmetro e, a partir da análise desses gráficos, buscou-se referência para a determinação do background;

c) Análise estatística - tal qual mencionado anteriormente, entretanto, separando poços dentro da área da INB e poços afastados, fora do complexo, bem como poços em granitos e gnaisses separados daqueles encontrados em quartzitos e rochas metapiroclásticas. $O$ objetivo foi estabelecer a influência da atividade de mineração e do contexto litológico, e suas possíveis interferências nas concentrações dos diversos parâmetros físico-químicos detectados nas águas subterrâneas;

d) Análises excluindo as anomalias - considerando que os outliers, ou valores atípicos fogem do conceito de background, esses valores foram desconsiderados em determinadas análises, para se chegar as concentrações naturais mais realistas dos parâmetros no aquífero.

\subsubsection{Urânio}

De acordo com Silva (2011), apesar de possuir vários estados de valência, apenas os estados 4+ e 6+ são encontrados, em quantidades significativas, no ambiente natural. Quando os valores de $\mathrm{pH}$ encontram-se entre 4 e 9, a uraninita é extremamente insolúvel nas águas naturais, e nessas condições, o $U^{4+}$ permanece praticamente imóvel em solução.

Como pode ser observado na Figura 2.1, toda a região onde ocorrem biotita gnaisses (gnaisse zebra), é rica em corpos de albititos. Considerando que as anomalias de urânio encontram-se nesses albititos, espera-se que os teores observados nas águas subterrâneas também sejam mais altos, em comparação com aquíferos, cuja rocha não apresente essa anomalia.

Os valores de $\mathrm{pH}$ constatados, situam-se no campo da neutralidade, com média de 7,08, o que desfavorece a solubilidade da uraninita nas águas (Figura 4.32). 


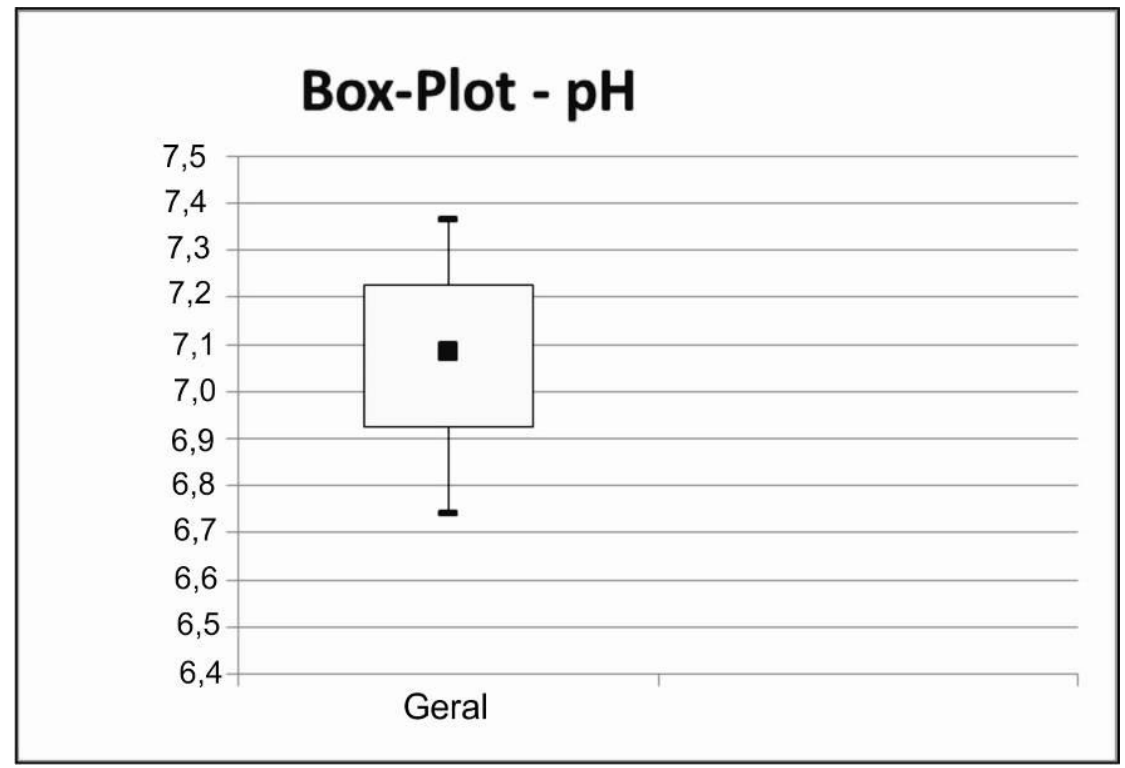

Figura 4.32 - Valores de pH amostrados nas águas subterrâneas, considerando todos os poços e todo o conjunto de dados disponíveis.

Nesse cenário, em toda a região, incluindo tanto os poços dentro dos limites do complexo da INB, quanto aqueles fora dessa área, o teor médio de urânio natural - englobando todos os isótopos de urânio, encontrado é $0,214 \mathrm{~Bq} / \mathrm{L}$ (não incluindo aqui as anomalias). Os poços com radioatividade anômala são PC- 09 (1,10Bq/L \pm 0,128), PC- 68 (8,06 Bq/L \pm 1,855) e PC- 01 (média de 10,11 Bq/L $\pm 1,204$ ). Os dois primeiros estão situados dentro da área do Complexo da INB, sendo que o PC-01 instalado em rocha gnáissica e o PC- 09 em rocha granítica. Já o PC-68 localiza-se fora da área da INB, construído em rocha gnáissica.

Considerando que a comunicabilidade das estruturas, neste sistema aquífero estudado, refere-se a interligação que as descontinuidades sub-horizontais exercem no meio, e depende essencialmente de sua persistência e espaçamento, neste caso específico, nenhum desses três poços estão interligados. Como se observa no anexo 01 o PC-01 se situa logo a jusante da cava, o PC-09, próximo ao leito do Riacho das Vacas, e o PC- 68 se localiza fora dos limites da INB. Ainda, essas concentrações anômalas não foram observadas nos poços circunvizinhos a estes, indicando que há isolamento das águas desses poços. Na Figura 4.33 podem-se observar o valor máximo, mínimo, médio e mediano, primeiro quartil e terceiro quartil, referente as concentrações de U natural nas águas, a partir das médias de cada poço amostrado.

De acordo com os gráficos que retratam a variação dos teores de urânio natural nos poços amostrados, ao longo dos anos (Anexo 02), de maneira generalizada, os poços mantêm, desde as análises mais antigas, a mesma variação dos teores, exceto alguns poços onde se observa aumento da concentração (PC-01 e PC-155) e ou diminuição desses teores de urânio (PC-02, PC-03, PC-20, PC-43, PC-105, PC-113 e PC- 137). 


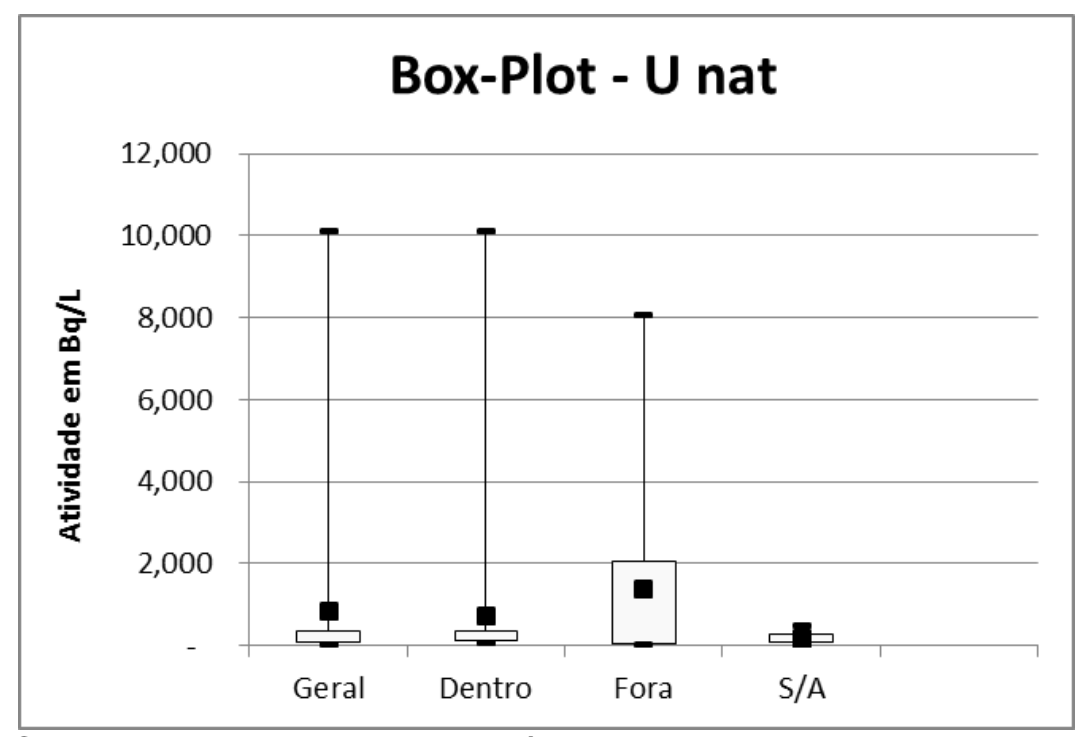

Figura 4.33 - Concentrações de U natural nas águas amostradas, considerando todos os valores (geral), poços dentro da área do Complexo da INB (dentro), poços fora da área da INB (fora) e todos os poços, porém, desconsiderando as anomalias.

Como se observa nas figuras 4.34, 4.35, 4.36 e 4.37, exceto as anomalias (PC- 01, PC09 e PC-68), a concentração máxima observada é inferior a 0,5 Bq/L. Nesse sentido, estabeleceu-se, como background para toda área, todos os valores de radioatividade abaixo do valor encontrado no terceiro quartil, que representa a concentração de $75 \%$ do volume amostrado. Esse teor corresponde a 0,26 Bq/L.

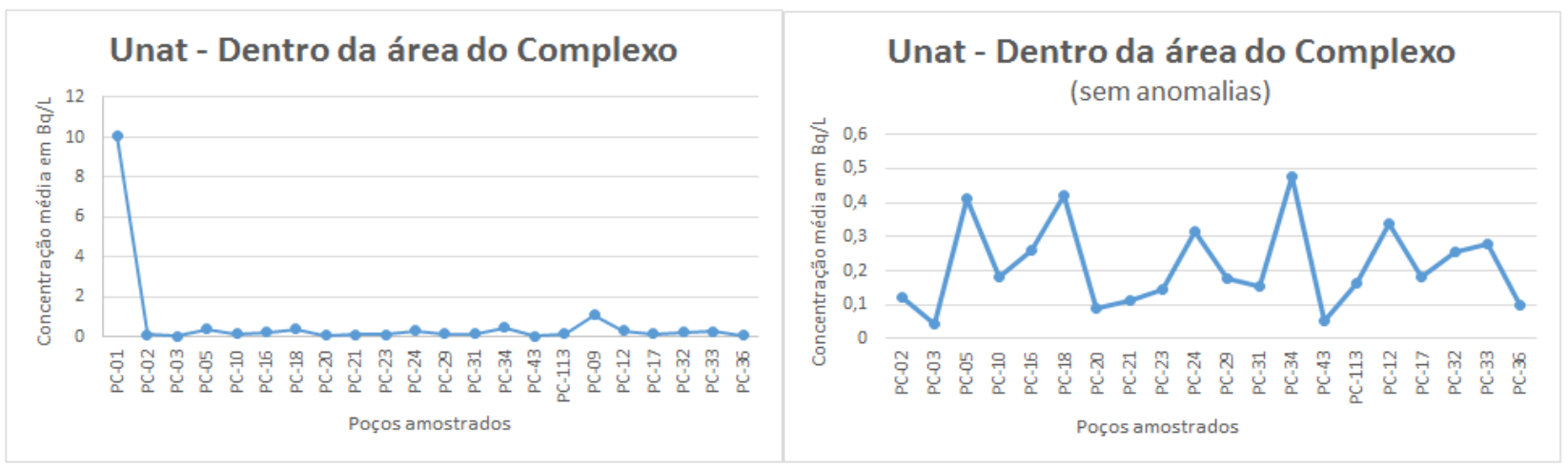

Figura 4.34 - Concentrações de U natural nas águas amostradas, considerando os poços dentro dos limites da INB.
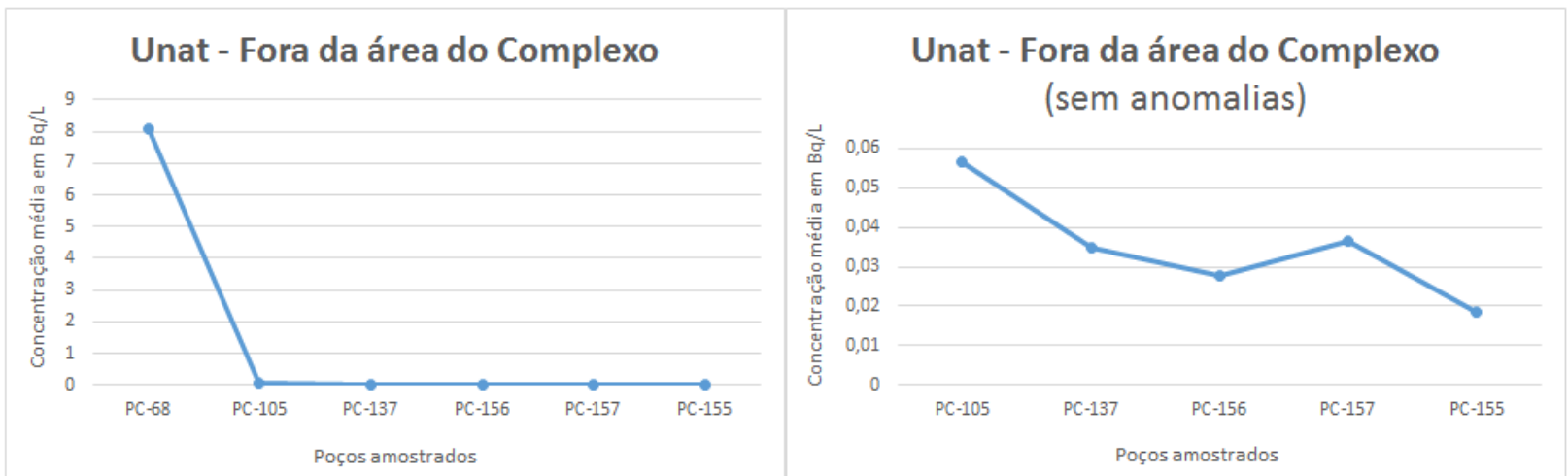

Figura 4.35 - Concentrações de U natural nas águas amostradas, considerando os poços fora dos limites da INB. 


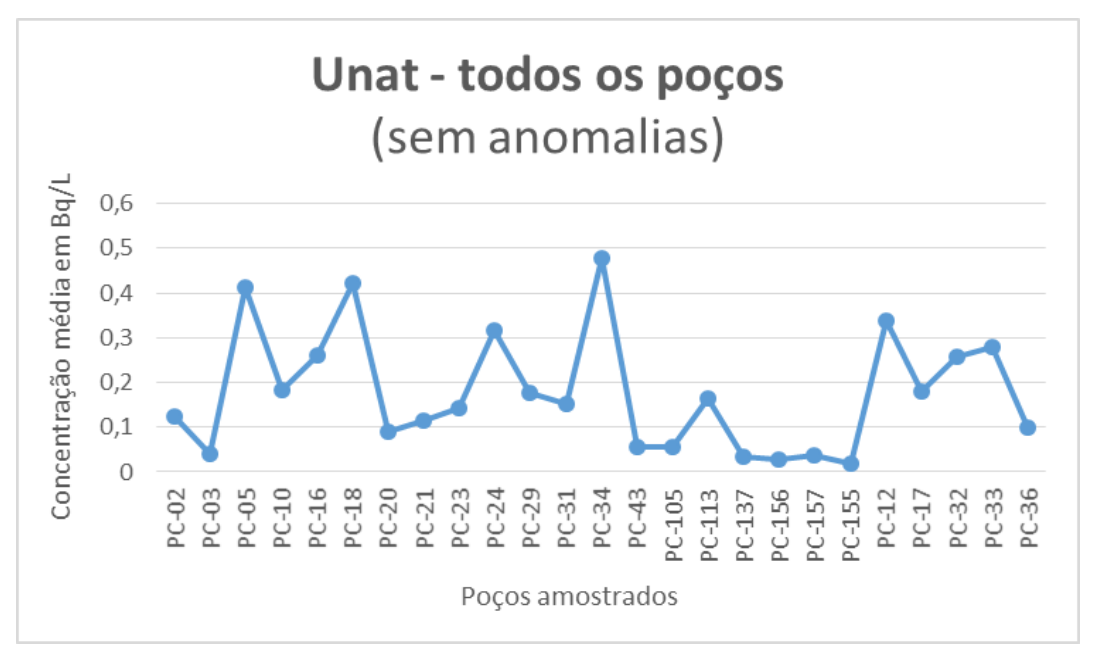

Figura 4.36 - Concentrações de U natural nas águas amostradas, considerando todos os poços.

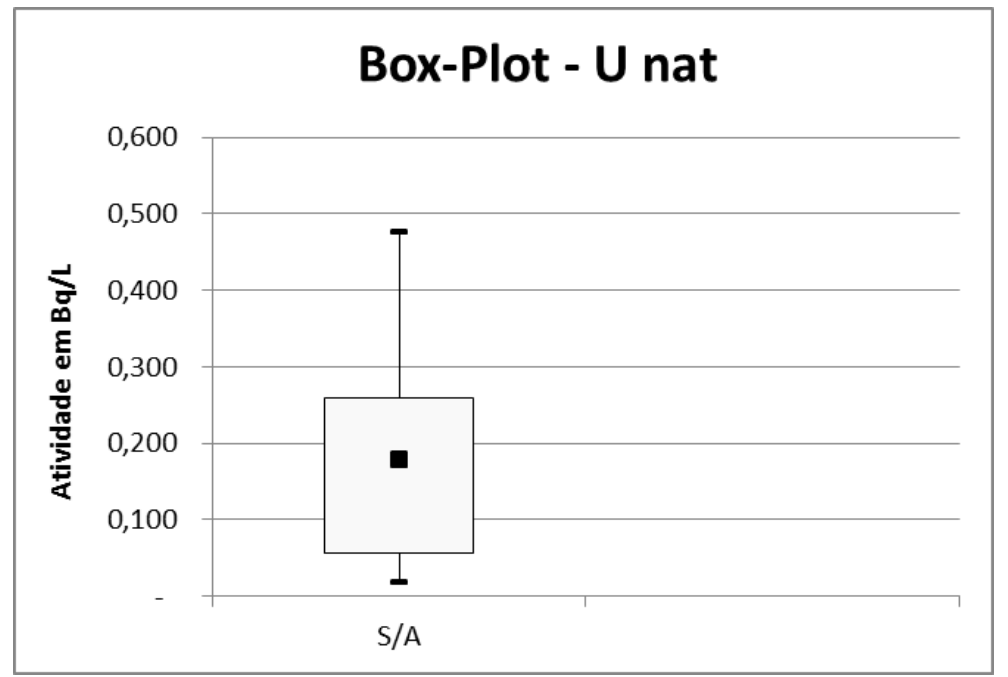

Figura 4.37 - Concentrações de U natural nas águas amostradas, considerando todos os poços.

Acima do valor de background valor definiu-se mais três faixas, uma entre 0,26 a 0,48, 0,48 a $8 \mathrm{~Bq} / \mathrm{L}$ e a última entre 8 e $11 \mathrm{~Bq} / \mathrm{L}$ (Figura 4.38).

Os poços anômalos encontram-se nos gnaisses, onde ocorrem os albititos mineralizados. Logo, essas anomalias estão intrinsecamente relacionadas a composição química das rochas, que influencia diretamente nas concentrações desse radionuclídeo, bem como na radioatividade detectada nesses poços.

Ainda, esses pontos anômalos contribuem para o entendimento da comunicabilidade do aquífero. $\mathrm{O}$ isolamento desses poços, principalmente os dois localizados dentro da área da INB que, claramente, não se comunicam com a vizinhança, tendo em vista que as anomalias estão restritas, denotam pontos de estagnação das águas em determinadas regiões do sistema aquífero. Nessas regiões, possivelmente, as estruturas sub-horizontais não apresentam persistência suficiente ou abertura para ligar essas áreas com o restante do sistema. 


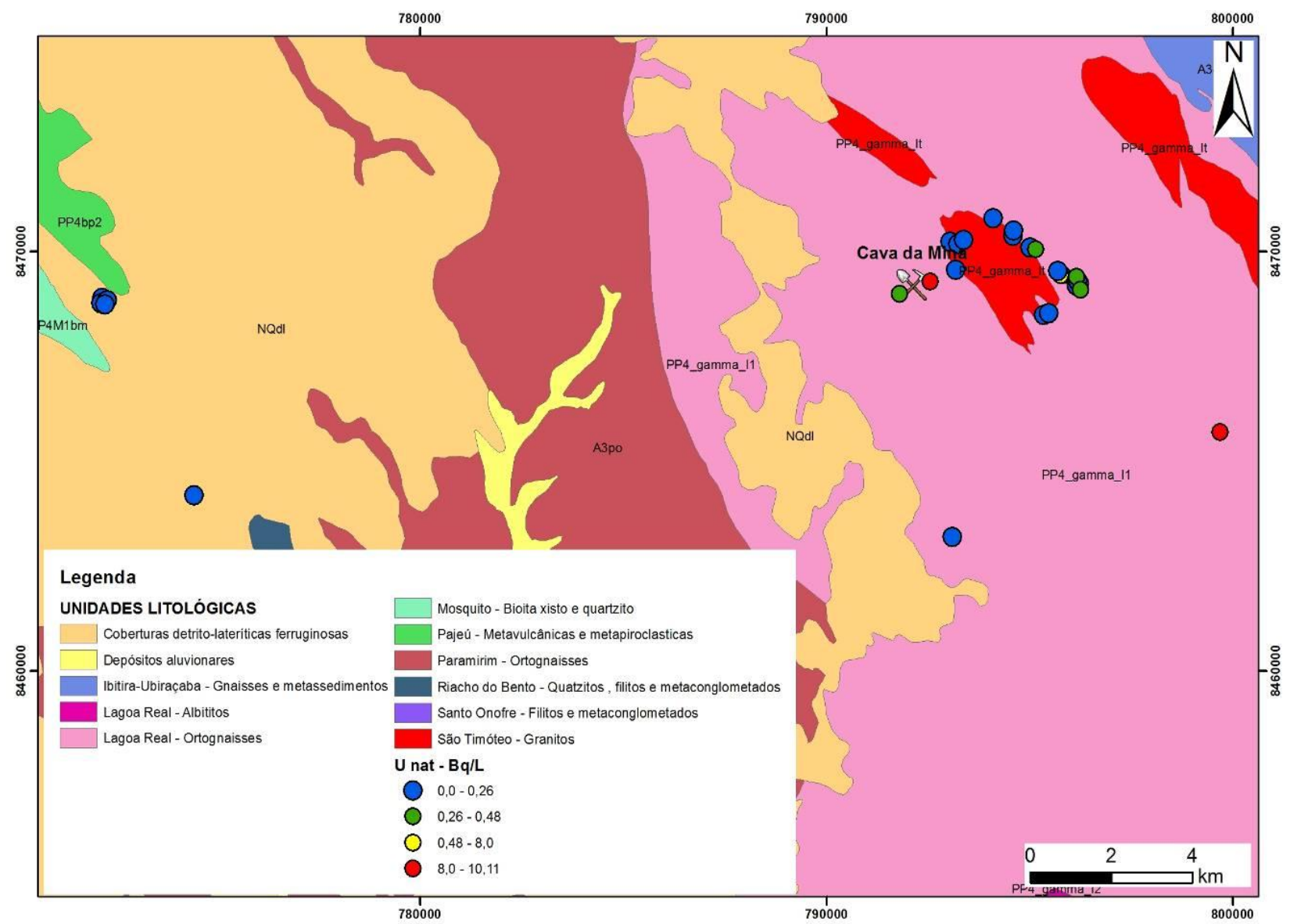

Figura 4.38 - Background para a radioatividade do U natural representado por pontos azuis, em amarelo e vermelho as duas outras classes, que englobam as anomalias.

\subsubsection{Nitrato}

No caso do nitrato, a determinação de background, tal qual foi estabelecida, não pode ser aplicada, considerando que o $\mathrm{NO}_{3}$ não ocorre em quantidades relevantes nas rochas e no solo da região.Sua presença é indicadora de atividade antrópica, especialmente neste caso, urina de animais e lançamento de esgoto sanitário sem tratamento. Sendo assim, no caso do nitrato, a determinação do background não se baseou na análise estatística, ou na correlação com as rochas da região. Em face das concentrações elevadas resultarem de atividade antrópica, optouse por estabelecer o valor de baseline (linha de base referencial) de acordo com o limite máximo permitido pela Portaria 2.914 de 12 de dezembro de 2011, do Ministério da Saúde.Não foi possível propor valores naturais de background pois não existem dados antigos disponíveis (anteriores a ocupação dessa área).

Tendo em vista que o nitrato é uma substância química que representa risco à saúde, o padrão de potabilidade para consumo humano estabelece, como concentração máxima permitida, $10 \mathrm{mg} / \mathrm{L}$ de nitrato, o equivalente a $44 \mathrm{mg} / \mathrm{L}$ de nitrogênio de nitrato $\left(\mathrm{N}-\mathrm{NO}_{3}\right)$ na água. Sendo assim, considerou-se como valor de baseline teores de nitrato até $10 \mathrm{mg} / \mathrm{L}$. De acordo com os valores encontrados (Figura 4.30), estipulou-se mais 5 classes, cujos intervalos menores atendem as classes com maior concentração de medidas, e os maiores, aquelas classes com menor número de resultados encontrados, sejam elas: 10 a $20 \mathrm{mg} / \mathrm{L}, 20$ a $30 \mathrm{mg} / \mathrm{L}, 30$ a 50 
mg/L, 50 a 70 mg/L e 70 a 90 mg/L. Assim, na Figura 4.39 pode-se visualizar os distintos teores de nitrato, encontrados nas águas subterrâneas da região. Destaca-se que todas as amostras acima do baseline são impróprias para consumo humano, de acordo com a Portaria 2.914 de 2011, do Ministério da Saúde.

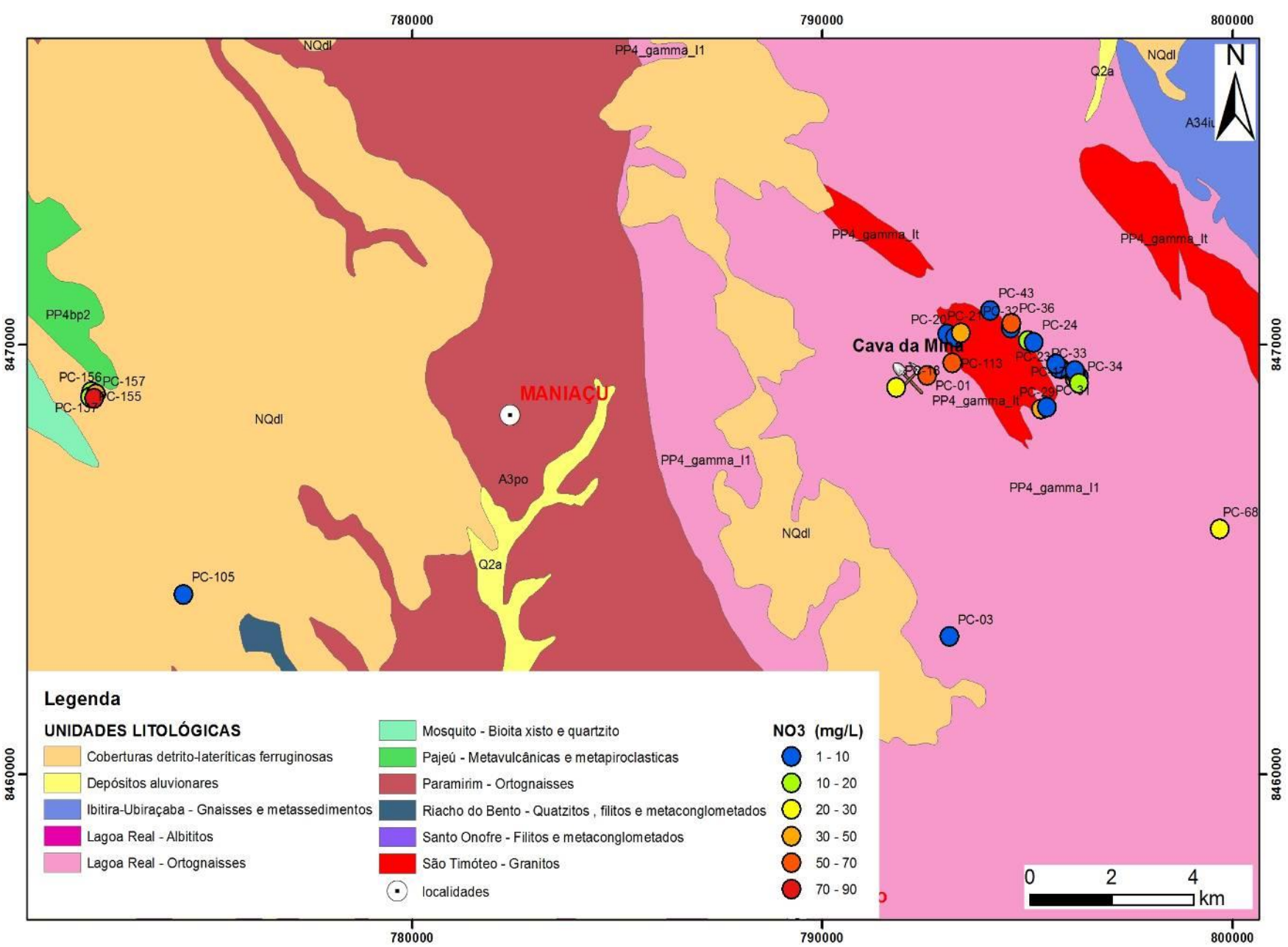

Figura 4.39 - Baseline para nitrato representado por pontos azuis, em verde, amarelo, laranja, abóbora e vermelho encontram-se as classes representando as concentrações de $\mathrm{NO}_{3}$, do menor valor para o maior, respectivamente.

\subsection{3 $\mathrm{Ca}-\mathrm{Na}-\mathrm{Cl} \mathrm{e} \mathrm{SO}_{4}$}

De acordo com o diagnóstico das concentrações do cálcio, sódio, cloro e sulfato, determinado anteriormente, verificam-se que os teores dessas substâncias variam muito, quando comparados os valores encontrados nas rochas graníticas e gnáissicas, com aqueles observados nos poços instalados em quartzitos, ou rochas metapiroclásticas. Nos primeiros poços, as concentrações superam abundantemente os últimos (Tabela 4.4 e Figura 4.40).

Dessa forma, o estabelecimento do background para a área de interesse, baseou-se nos poços instalados em rochas, comprovadamente, graníticas (Granito São Timóteo) e gnáissicas do Complexo Lagoa Real. De forma a evitar a interferência da exposição da rocha, através da atividade de mineração, selecionou-se os dados até o início da operação, que se deu em 1999. 
mediana, que representa melhor a tendência central, mais representativa do todo. Sendo assim, os valores definidos como background correspondem às concentrações menores ou iguais a: $67,66 \mathrm{mg} / \mathrm{L} \rightarrow \mathrm{Ca} ; 12,267 \mathrm{mg} / \mathrm{L} \rightarrow \mathrm{SO}_{4} ; 135 \mathrm{mg} / \mathrm{L} \rightarrow \mathrm{Na}$ e 169,1 mg/L $\rightarrow \mathrm{Cl}$

\begin{tabular}{|c|c|c|c|c|c|c|c|c|c|}
\hline $\begin{array}{l}\text { Granito/ } \\
\text { Gnaisses }\end{array}$ & $\mathrm{Ca}$ & $\mathrm{SO}_{4}$ & $\mathrm{Na}$ & $\mathrm{Cl}$ & $\begin{array}{c}\text { Quartizito/ } \\
\text { Metapiroclásticas }\end{array}$ & $\mathrm{Ca}$ & $\mathrm{SO}_{4}$ & $\mathrm{Na}$ & $\mathrm{Cl}$ \\
\hline máximo & 113,175 & 40,2 & 324 & 807,5 & máximo & 11,0809 & 1,87263 & 8,007692 & 14,80955 \\
\hline Q3 & 78,05 & 23,775 & 298 & 397,2915 & Q3 & $\begin{array}{l}11,0809 \\
\end{array}$ & 1,87263 & 8,007692 & 14,80955 \\
\hline média & 65,84782 & 14,3625 & 182,7727 & 278,1065 & média & 8,350613 & 1,615913 & 6,473397 & 10,29962 \\
\hline mediana & 67,66 & 12,26667 & 135 & 169,1 & mediana & 8,068634 & 1,512829 & 5,8125 & 8,801959 \\
\hline $\mathrm{Q} 1$ & 50,19 & 2 & 75 & 123,0625 & Q1 & 5,902306 & 1,462279 & 5,6 & 7,287348 \\
\hline Mínimo & 29,766 & 1 & 32 & 65,875 & Mínimo & 5,902306 & 1,462279 & 5,6 & 7,287348 \\
\hline
\end{tabular}

Tabela 4.4 - Tratamento estatístico das concentrações médias de cálcio, sulfato, sódio e cloro obtidas das análises de amostras de água oriundas dos poços até o início da operação (1999). Essas são as análises mais antigas, que serviram de base para a determinação do background.

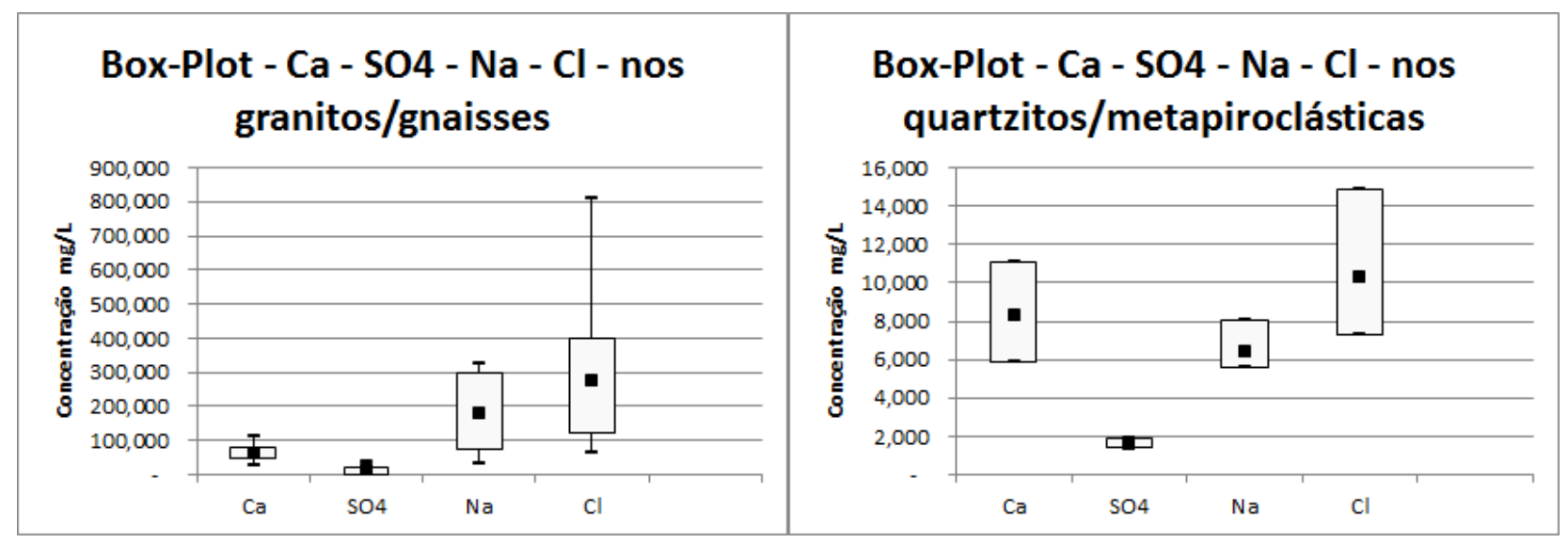

Figura 4.40 - Distribuição das concentrações médias de cálcio, sulfato, sódio e cloro obtidas das análises dos poços até o início da operação (1999). Tais resultados representam as análises mais antigas, que serviram de base para a determinação dos valores de background.

Nota-se que os teores encontrados inicialmente, já eram elevados, quando comparados os dados apresentados na Tabela 4.5 e na Figura 4.41 que retratam os valores médios, a partir dos dados históricos da distribuição desses parâmetros, em todos os poços. De acordo com os dados, estabeleceram-se classes, subdividindo os teores acima dos backgrounds supracitados, quais sejam: no caso do cálcio, as classes determinadas foram 67,66 mg/L a $100 \mathrm{mg} / \mathrm{L}, 100$ $\mathrm{mg} / \mathrm{L}$ a $200 \mathrm{mg} / \mathrm{L}$ e $200 \mathrm{mg} / \mathrm{L}$ a $314 \mathrm{mg} / \mathrm{L}$ (Figura 4.42); para o sulfato, também definiu-se três classes, 12,26 mg/L a 50 mg/L, $50 \mathrm{mg} / \mathrm{L}$ a $80 \mathrm{mg} / \mathrm{L}$ e de $80 \mathrm{mg} / \mathrm{L}$ a $120 \mathrm{mg} / \mathrm{L}$ (Figura 4.43); em se tratando do sódio designou-se duas classes, $135 \mathrm{mg} / \mathrm{L}$ a $200 \mathrm{mg} / \mathrm{L}$ e $200 \mathrm{mg} / \mathrm{L}$ a $324 \mathrm{mg} / \mathrm{L}$ (Figura 4.44); finalmente, no que se refere ao cloro, delimitou-se quatro classes, $169,1 \mathrm{mg} / \mathrm{L}$ a $200 \mathrm{mg} / \mathrm{L}, 200 \mathrm{mg} / \mathrm{L}$ a $300 \mathrm{mg} / \mathrm{L}, 300 \mathrm{mg} / \mathrm{L}$ a $400 \mathrm{mg} / \mathrm{L}$ e 400 mg/L a 637,68 mg/L (Figura 4.45). 


\begin{tabular}{|c|c|c|c|c|}
\hline mg/L & Ca & SO4 & Na & Cl \\
\hline máximo & 313,9911 & 114,4731 & 324 & 637,6764 \\
\hline Q3 & 85,26763 & 42,83679 & 150,7717 & 236,3256 \\
\hline média & 71,36191 & 30,19214 & 124,4189 & 167,6101 \\
\hline mediana & 67,88375 & 27,08767 & 110,9456 & 123,8488 \\
\hline Q1 & 47,40529 & 9,265505 & 88,15232 & 96,30581 \\
\hline Mínimo & 5,902306 & 1,462279 & 5,6 & 7,287348 \\
\hline
\end{tabular}

Tabela 4.5 - Tratamento estatístico dos dados de concentrações médias de cálcio, sulfato, sódio e cloreto obtidos das análises históricas englobando todos os poços.

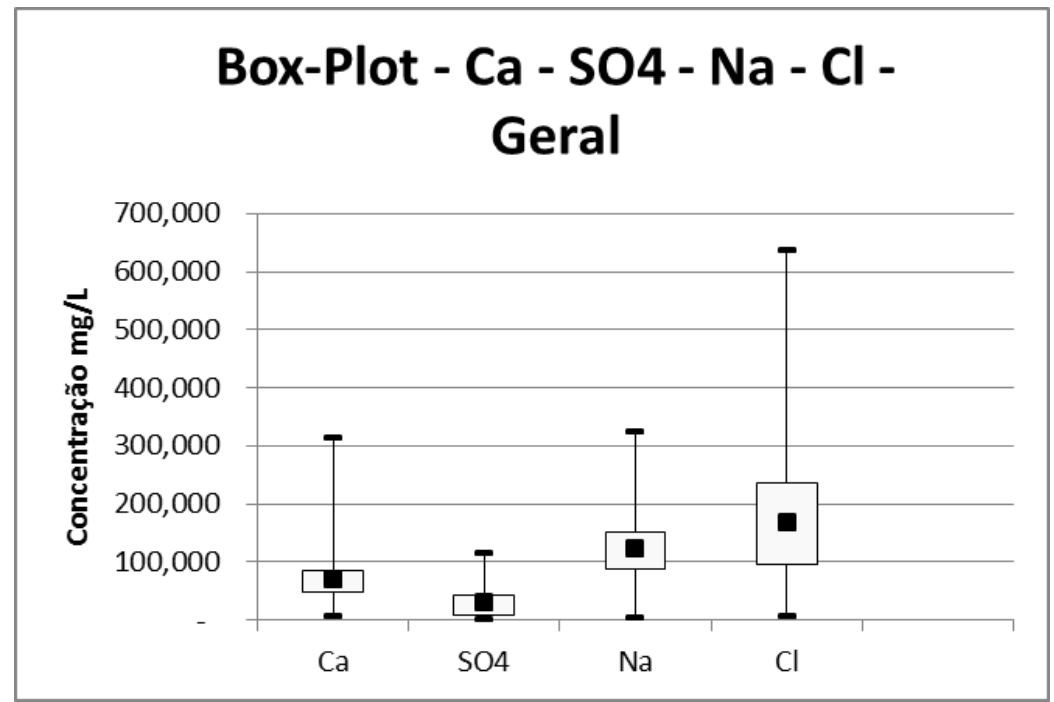

Figura 4.41 - Distribuição das concentrações médias de cálcio, sulfato, sódio e cloro obtidas de análises de águas de todos os poços ao longo de todo o tempo de monitoramnto.

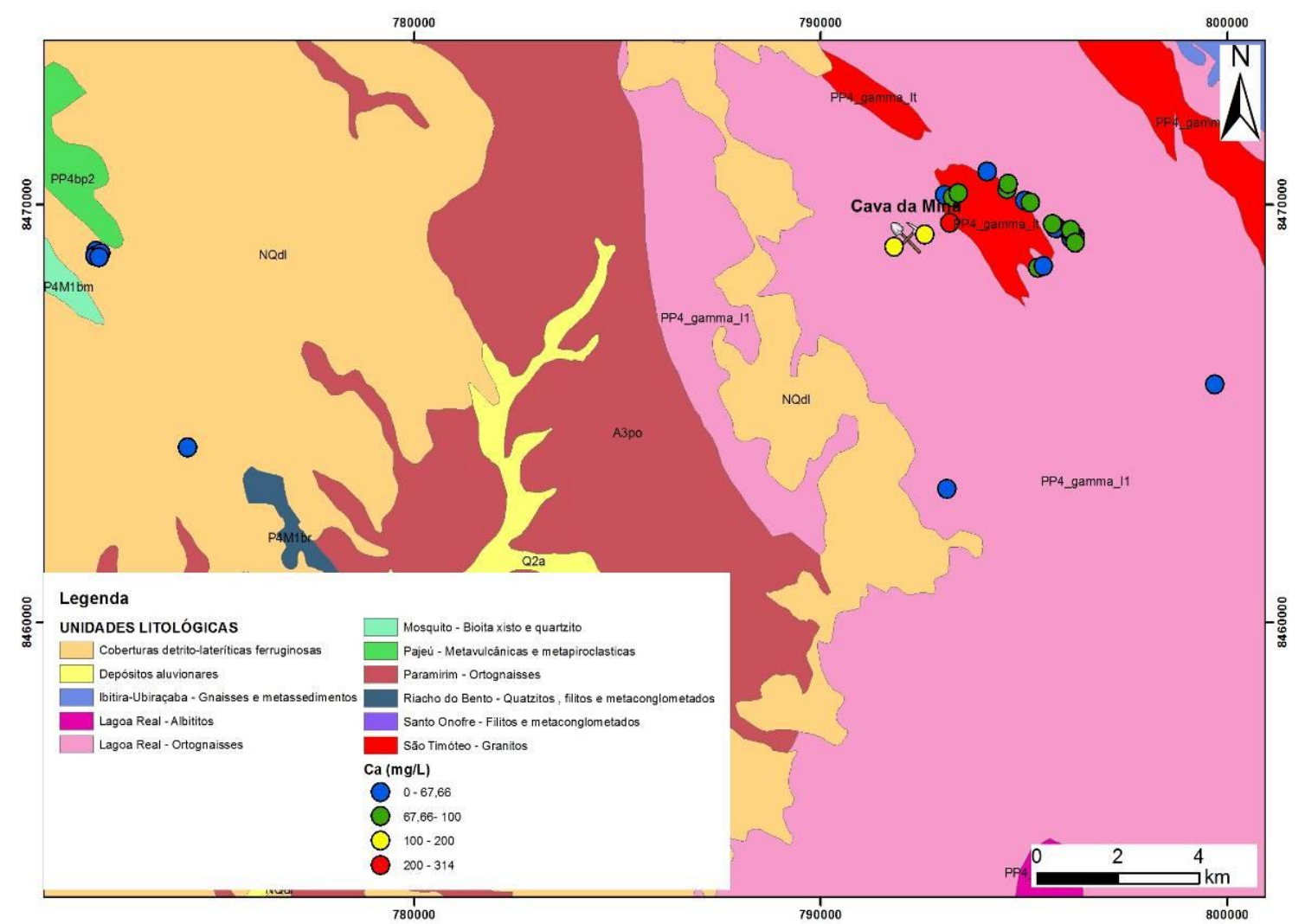

Figura 4.42 - Background para o cálcio representado por pontos azuis. Em verde, amarelo e vermelho encontram-se as classes representando as concentrações anômalas de $\mathrm{Ca}$, do menor valor para o maior teor, respectivamente. 


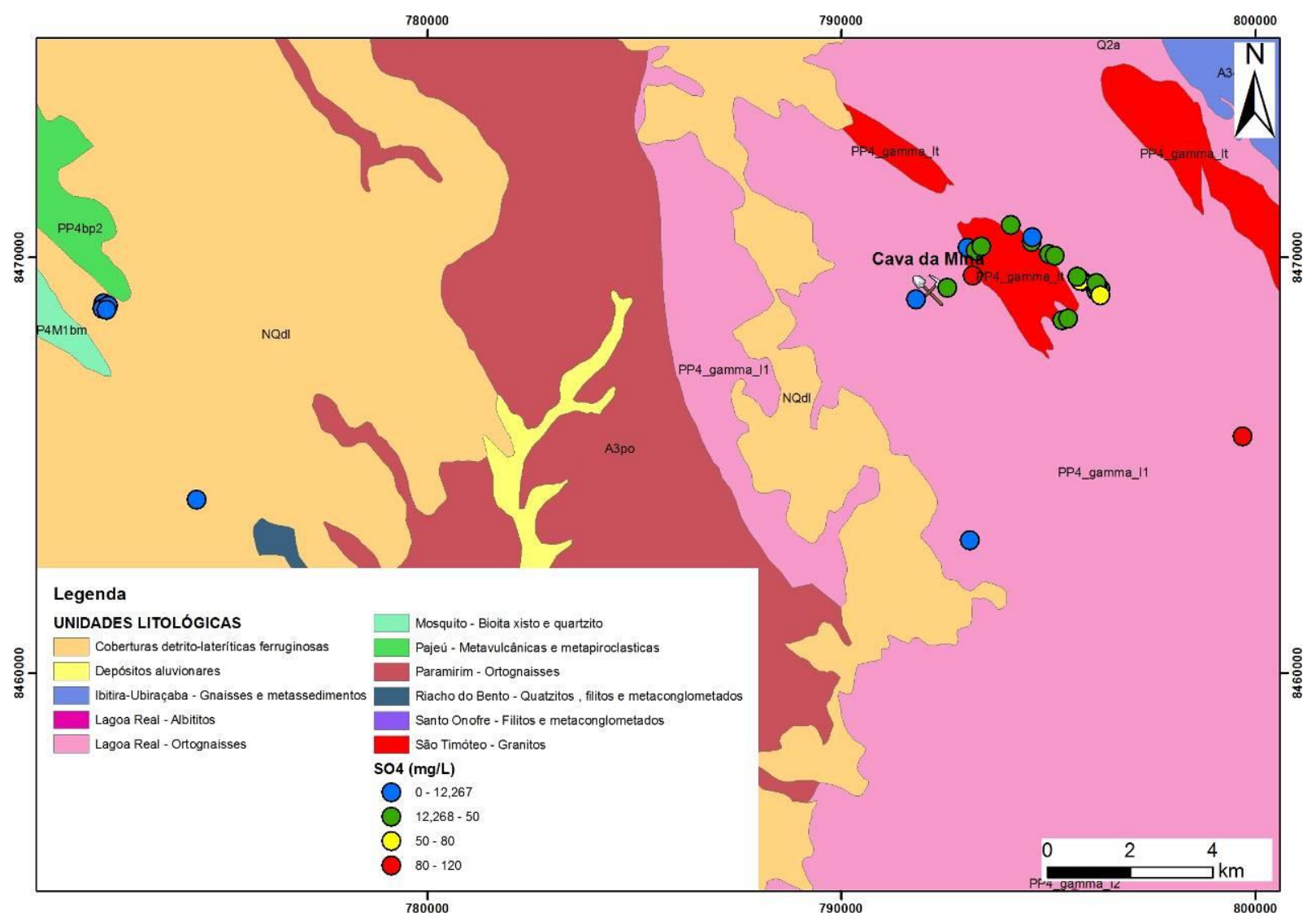

Figura 4.43 - Background para o sulfato representado por pontos azuis. Em cores verde, amarelo e vermelho encontram-se as classes representando as concentrações anômalas de $\mathrm{SO}_{4}$, respectivamente, do menor valor para o maior teor.

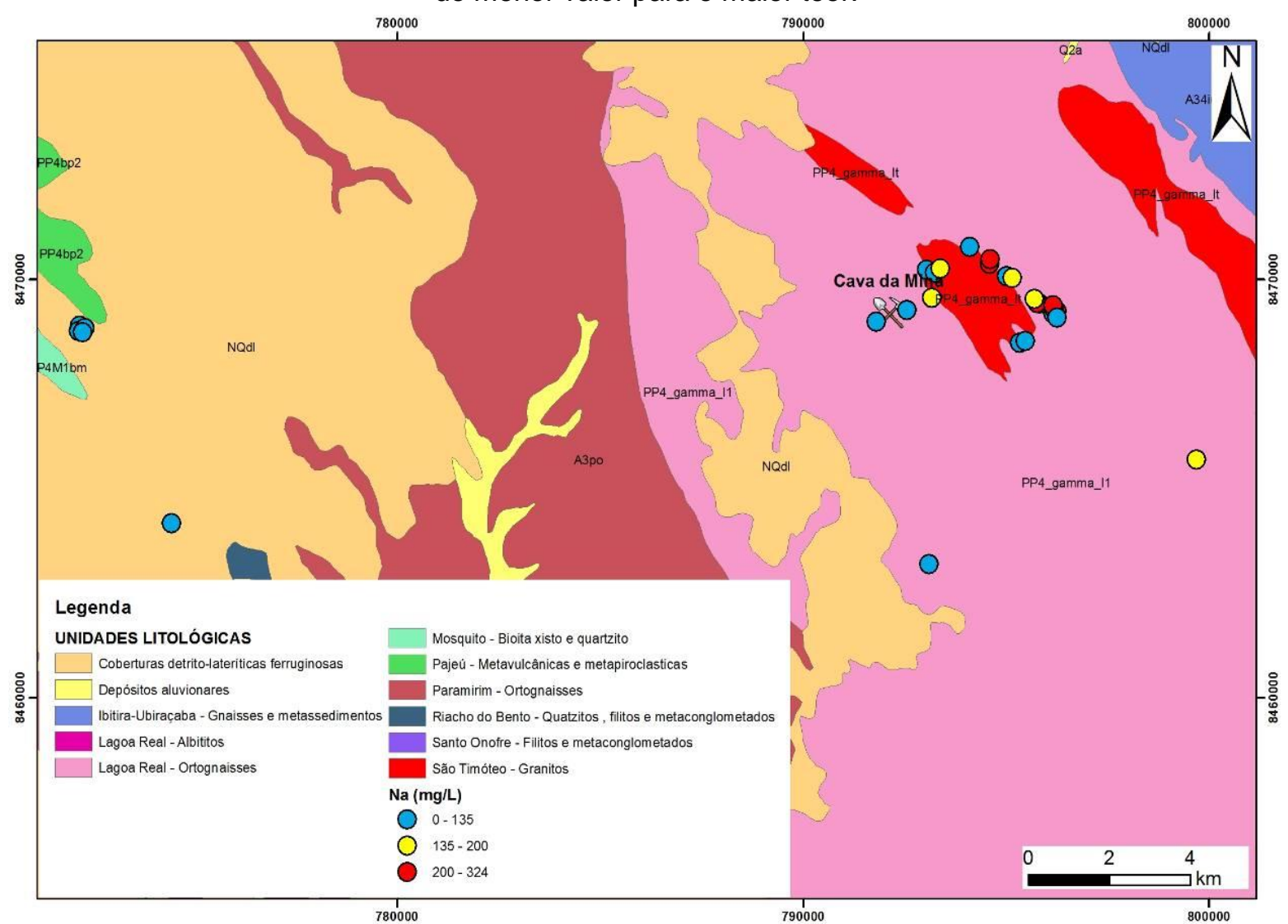

Figura 4.44 - Valores de background para o sódio representado por pontos azuis. Em amarelo e vermelho encontram-se as classes representando as concentrações crescentes de $\mathrm{Na}$. 


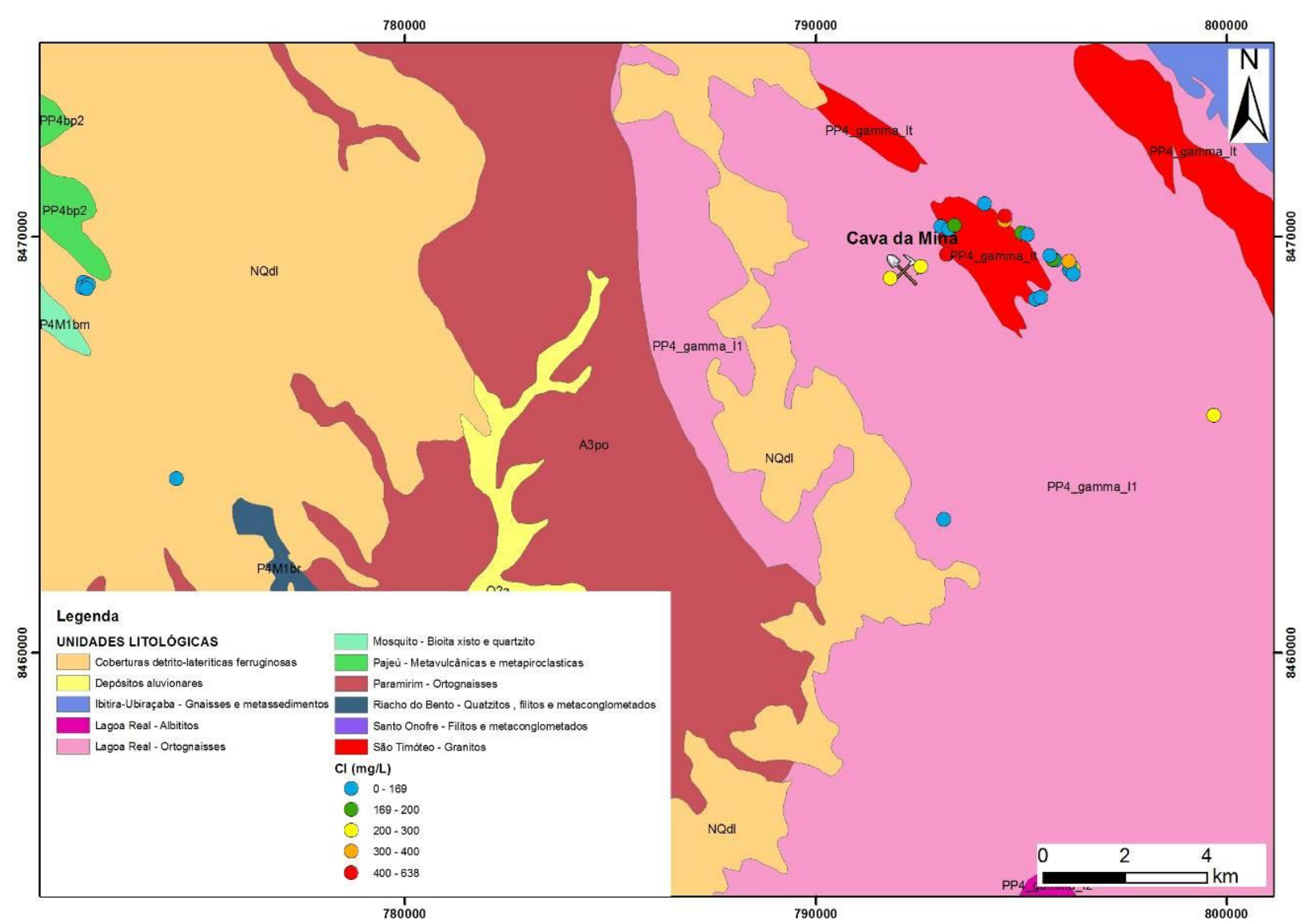

Figura 4.45 -Background para o cloreto representado por pontos azuis, em verde, amarelo, laranja e vermelho encontram-se as classes representando as concentrações de cloreto, do menor valor para o maior teor, respectivamente.

Dentre os poços analisados, dez foram selecionados para representação da composição da água, através do Diagrama de Stiff. Nele, as concentrações iônicas em meq/L são representadas sobre linhas paralelas horizontais, sendo que, do lado direito são plotados os ânions $\left(\mathrm{Cl}, \mathrm{F} \mathrm{e} \mathrm{SO}_{4}\right)$ e do esquerdo, os cátions ( $\mathrm{Na}+\mathrm{K}, \mathrm{Ca}$ e $\mathrm{Mg}$ ), resultando numa figura geométrica característica para cada amostra de água analisada.

Os poços selecionados foram: PC - 137 e PC - 105 (instalados em quartzito e rocha metapiroclástica), PC - 16 e PC - 18 (perfurados em rocha granítica), PC - 20, PC - 23, PC - 34, PC - 36 e PC - 68 (posicionado em rocha gnáissica) e PC - 31.

Como se observa na Figura 4.46, todos os poços dentro e fora do complexo da INB, perfurados em rochas graníticas e gnáissicas seguem o mesmo padrão, revelando águas ricas em cloreto e sódio. Já os poços 105 e 137 retratam águas empobrecidas em íons, fato que corrobora com a natureza dessas rochas (quartzitos e rochas metapiroclásticas), notadamente menos reativas que granitos e gnaisses. 


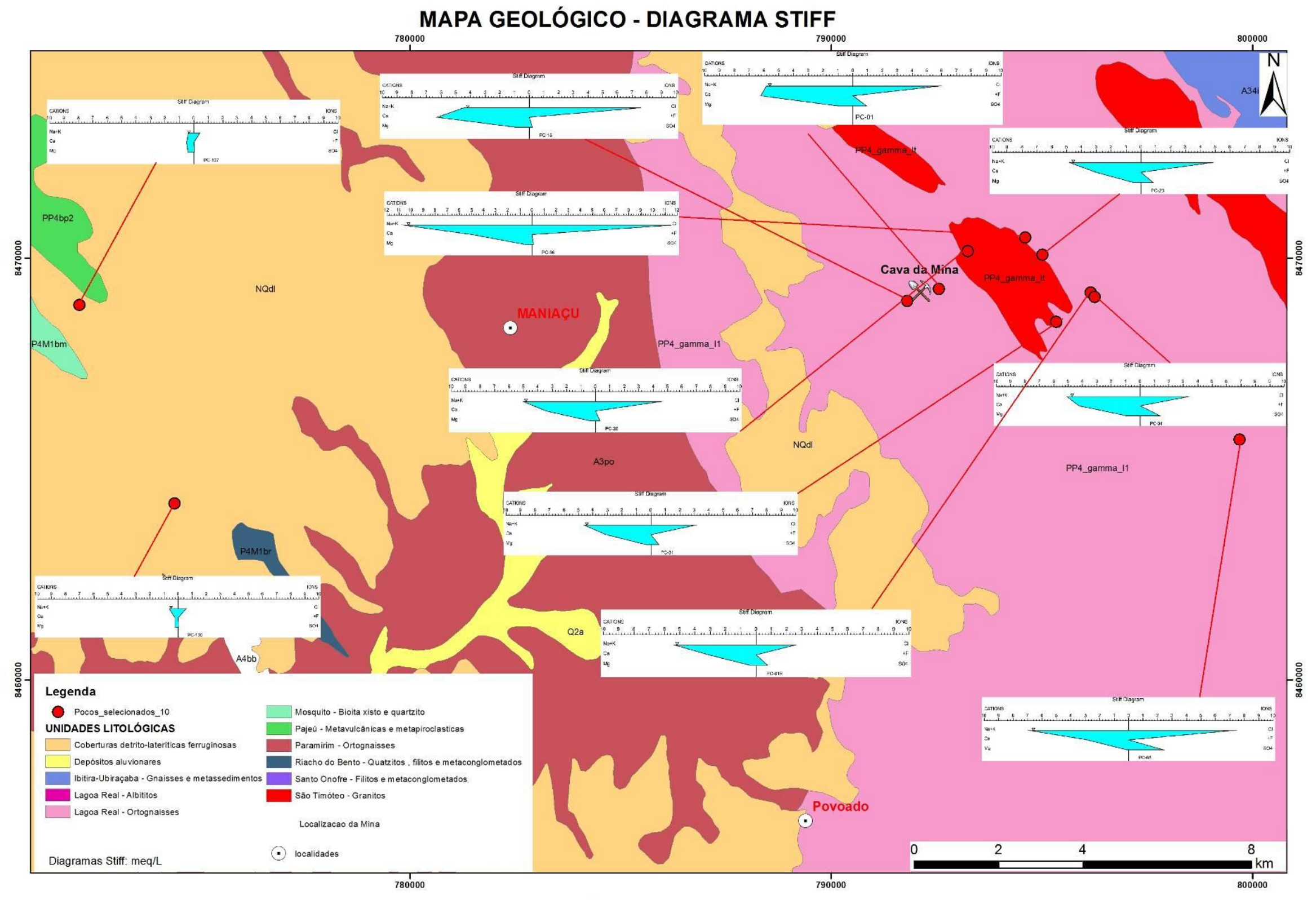

Figura 4.46 - Distribuição de padrões Stiff para amostras de água subterrânea com ampla distribuição geográfica na área em estudo. 


\subsection{Fluxo}

A circulação de água subterrânea nos aquíferos fraturados é condicionada pela quantidade, forma e interconexão das estruturas que provocam descontinuidade na rocha, gerando a chamada porosidade secundária, que serve como caminho para percolação e/ou acúmulo de água. Considerando o modelo conceitual proposto para este aquífero fraturado, com base no levantamento estrutural realizado na área, sabe-se que existem três famílias de descontinuidades principais que o compõem, constituídas pelas famílias NE, SW-W-NW e Subhorizontal. A primeira e a segunda, respectivamente, são responsáveis pela recarga, já a terceira responde pela interconexão de todo o sistema. Da análise dos parâmetros físico-químicos, amostrados regularmente, percebe-se que existem zonas de estagnação, onde se encontram anomalias de determinados parâmetros que não se observa nos poços circunvizinhos. Ainda, nos vales e regiões de declive, onde as descontinuidades são interceptadas pela topografia, há liberação da água subterrânea, do sistema aquífero para o exterior.

Nesse sentido, entende-se que existem estruturas sub-horizontais bastante persistentes, observáveis a grandes profundidades (até 150 metros), capazes de conectar as demais descontinuidades por extensas áreas, e ainda assim, ocorrem regiões notadamente sem conexão com o entorno.

Neste cenário, procurou-se estabelecer ligação entre os resultados obtidos, a partir da análise dos parâmetros físico-químicos, com a geologia estrutural observada na área.

\subsubsection{Poços secos e Produtores}

Dos poços perfurados na área em busca de fontes alternativas de abastecimento, uma parte considerável revelou-se improdutiva. Daqueles que foram produtores, muitos se localizam ao longo dos principais cursos d água (ainda que temporários), da região. Em função do controle estrutural dos aquíferos, estas áreas concentraram os esforços em busca de água (Figura 4.47).

A investigação dos perfis constritivos desses poços revela que, os poços secos são aqueles onde não se verificam descontinuidades (falha e junta), ou essas estruturas são rasas (Figura 4.48). Já os poços produtores de água, independentemente do tipo petrográfico que interceptam, apresentam descontinuidades mais profundas em seu perfil construtivo (Figura 4.49). Este fato ocorre, mesmo para os poços instalados nos vales, próximos as calhas dos corpos hídricos, o que reflete a pouca influência do meio poroso sobre o acúmulo de água, em decorrência do clima semiárido e do déficit hídrico observado na maior parte do tempo, tornando essas zonas mais rasas fortemente afetadas pela evaporação. 


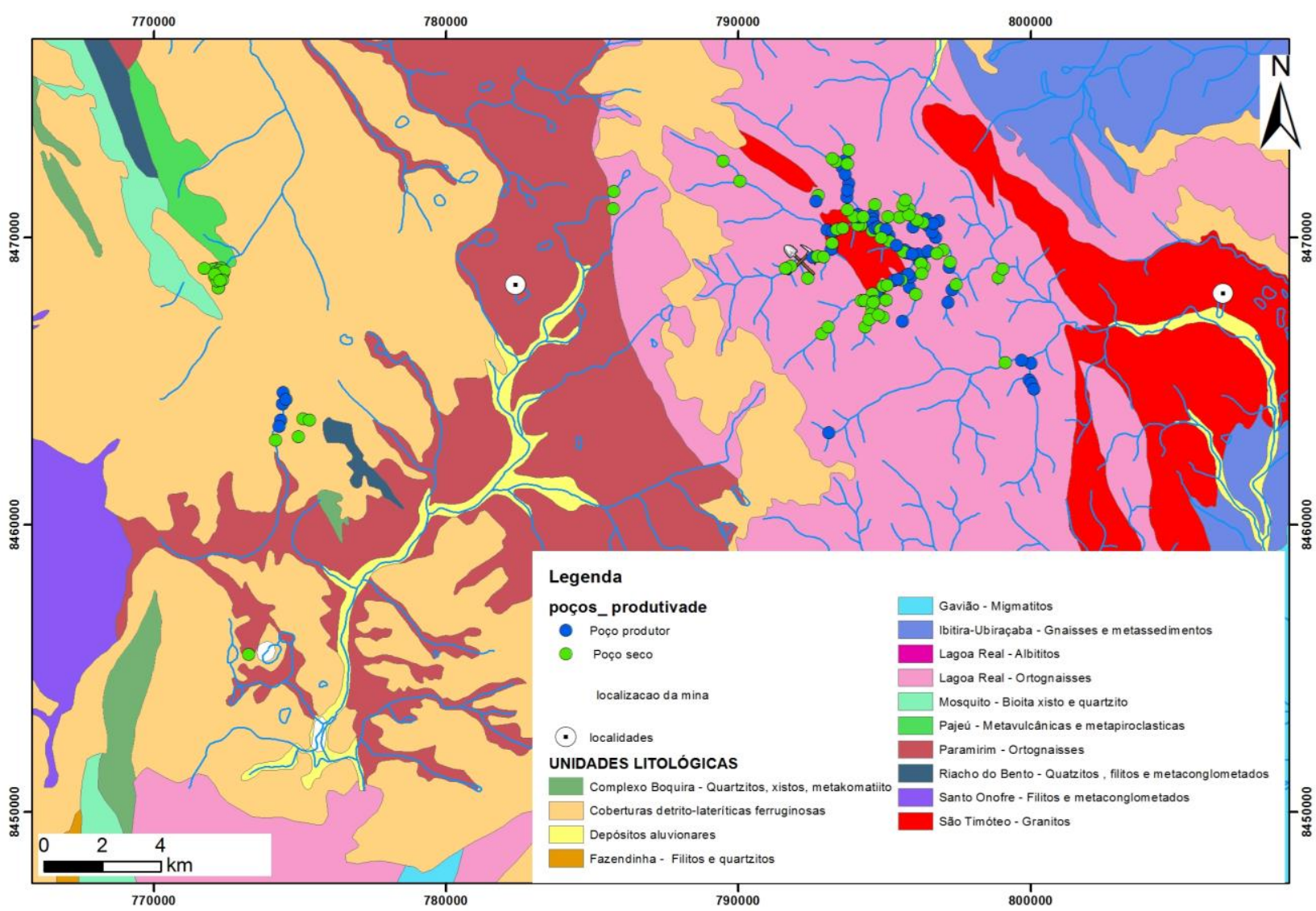

Figura 4.47 - Localização dos poços secos e produtores, fruto dos esforços para captação de água na região.

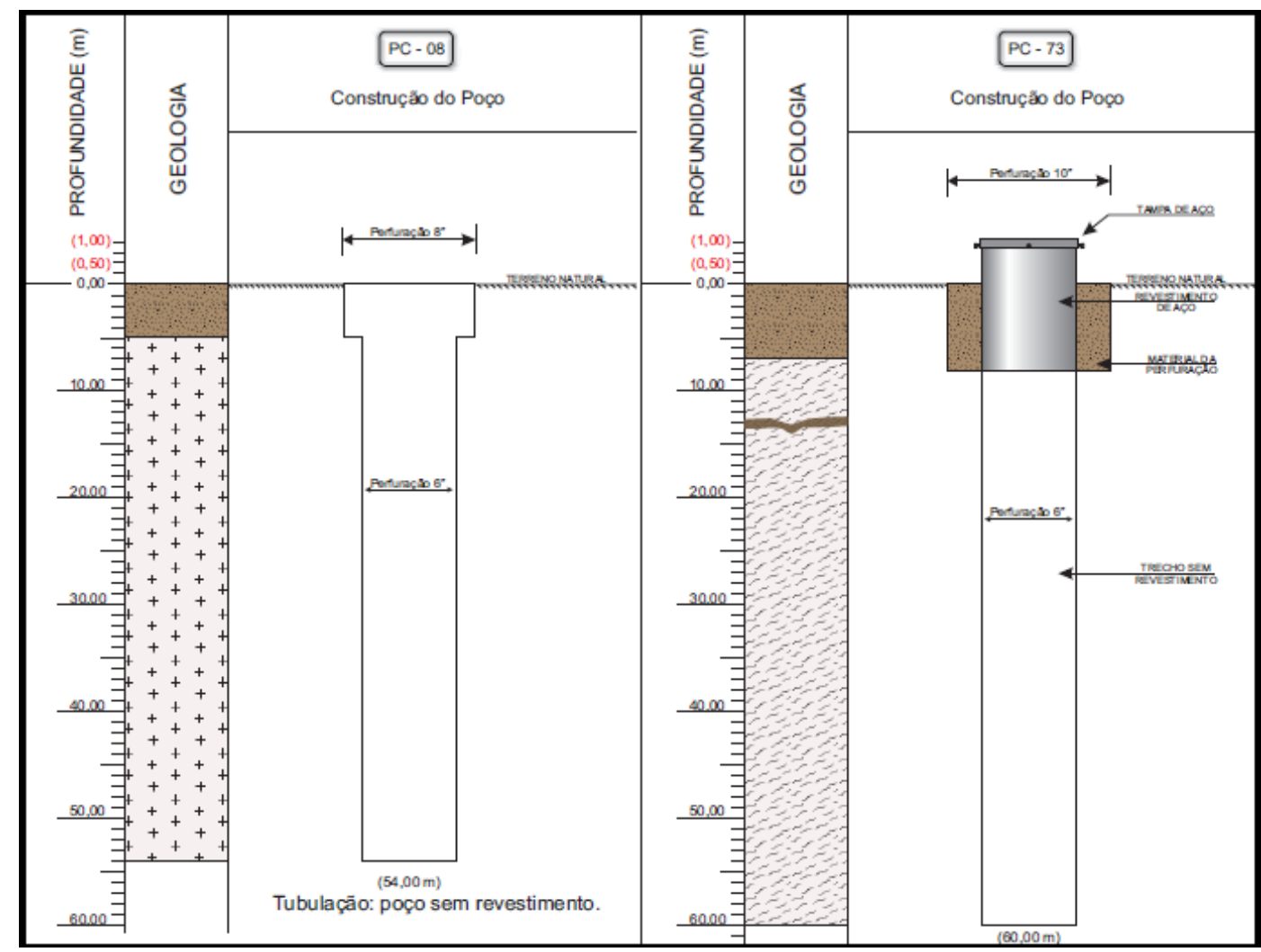

Figura 4.48 - Exemplo de perfil construtivo de poços secos. No primeiro caso, PC-08, instalado em rocha granítica e no segundo, PC-73 construído em rocha gnáissica. A linha horizontal na cor marrom, observadas no perfil do poço 73 , representa a descontinuidade que este poço atravessou. 


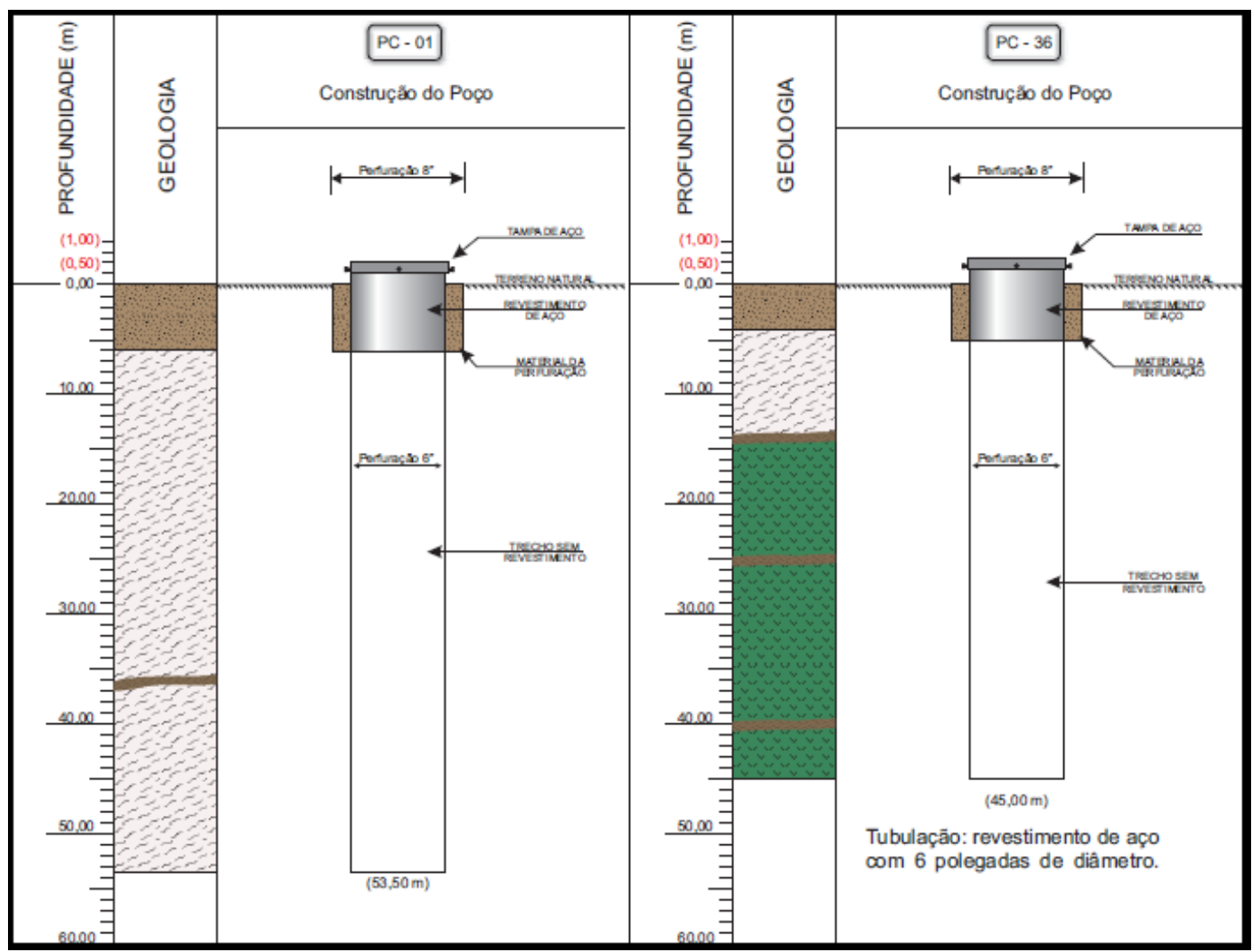

Figura 4.49 - Exemplos de perfis construtivos de poços produtores. No primeiro caso, $\mathrm{PC}$-01, instalado em rocha gnáissica e no segundo, $\mathrm{PC}-36$ construído no contato entre os gnaisses e o dique de diabásio. As linhas horizontais na cor marrom, observadas no perfil desses poços, representam as descontinuidades que foram interceptadas durante a perfuração.

\subsubsection{Controle estrutural}

De acordo com a descrição, realizada no capítulo anterior, sobre a Geologia da região, sabe-se que as estruturas com strike N45W (NW-SE) predominam na área de estudo. Isto pode ser constatado na orientação preferencial dos corpos de albititos (Figura 2.1), na atitude da foliação, no bandamento gnáissico, na principal família de descontinuidades identificada e principais zonas de cisalhamento (Figura 2.8). Considerando o Revelo Sombreado, baseado no Modelo Digital do Terreno (MDT/ASTER), obtido com posição de luz a N45E e $45^{\circ}$ sob a imagem ASTER GLOBAL DEM, consultado em 25/07/2015, a partir do site do Serviço Geológico Americano (USGS), buscou-se identificar os principais lineamentos estruturais, para suprir a escassez de informações do Mapa Geológico-Estrutural disponível. Procurou-se correlacionar esses dados com os resultados obtidos nas análises químicas, com o objetivo de identificar a influência das estruturas na distribuição da composição química das águas.

O primeiro parâmetro correlacionado foi o urânio. Suportado pelos dados estruturais constata-se que não há estrutura conectando os poços com as maiores anomalias (Figura 4.50), ou, tampouco, encontrou-se um padrão que comprove a existência de mobilidade desse isótopo dentro do sistema aquífero. Nesse caso, a ocorrência de anomalias desse elemento nas águas está diretamente relacionada a anomalia pontual nas rochas onde o poço estiver instalado. 


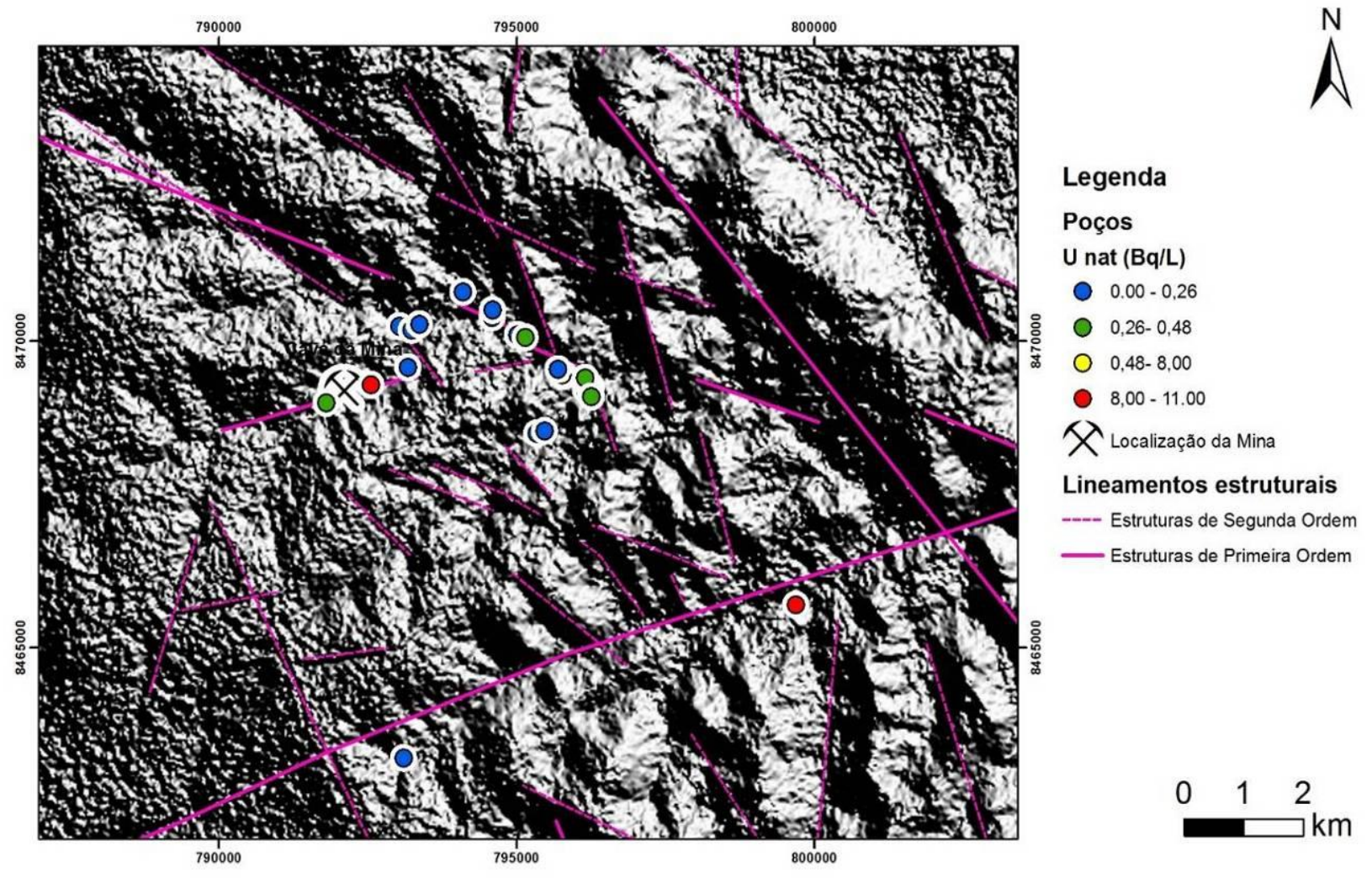

Figura 4.50 - Correlação entre a distribuição de U natural e os lineamentos estruturais identificados na região estudada.

Não há indícios de que a distribuição da concentração de cloreto, nas águas analisadas, tenha relação direta com a comunicação do aquífero através das descontinuidades levantadas. De acordo com o Diagrama de Stiff, pode-se concluir que existe o mesmo padrão de distribuição no sistema aquífero, tanto em rochas graníticas quanto gnáissicas, e muito diferente daquele observado nas rochas quartzíticas e metapiroclásticas. Entretanto, comparando as concentrações de $\mathrm{Cl}$ verificadas em alguns poços, com o gráfico de precipitação e evaporação total (Figura 4.51), pode-se perceber aumento significativo dos teores desse elemento nos períodos de estiagem. Sendo assim, entende-se que o background representa a concentração naturalmente presente em função dos tipos de rocha, mas os incrementos desses teores têm relação intrínseca com o clima semiárido e o processo de salinização do solo e das águas subterrâneas. 


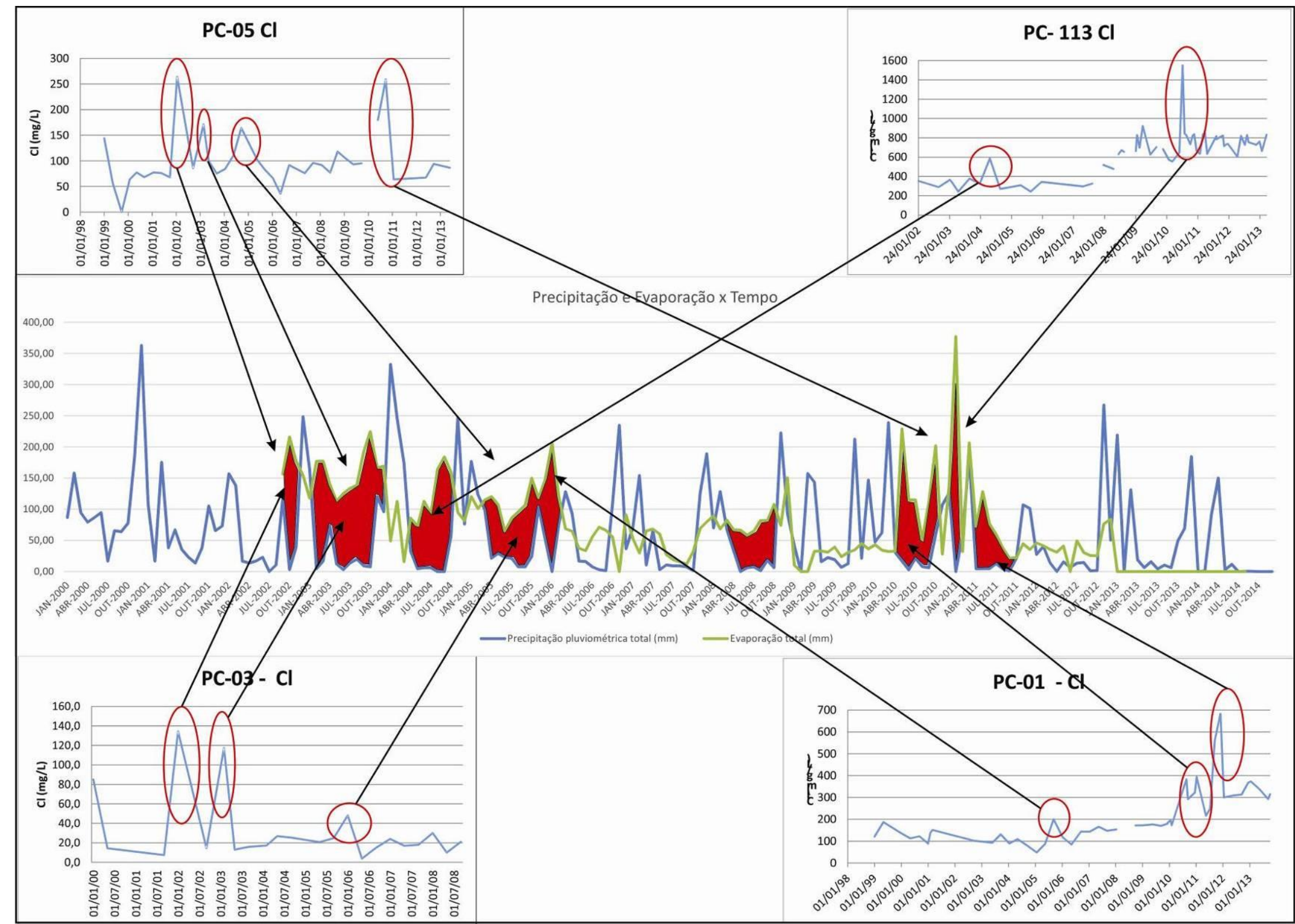

Figura 4.51 - Correlação entre a distribuição de cloreto com os parâmetros climáticos. Precipitação - linha azul, Evaporação - linha verde e em vermelho o déficit hídrico acumulado. 
O confronto entre cálcio, sódio e sulfato com o Mapa de Lineamentos Estruturais (Figura 4.52) demonstrou que essas estruturas regionais não são preponderantes na distribuição das concentrações dos parâmetros físico-químicos analisados. De fato, a partir dos resultados obtidos até o momento, o fator dominante é a composição da rocha. Como verificou-se do Diagrama de Stiff, os diferentes grupos de materiais rochosos determinam qual será o padrão de distribuição deste íons.

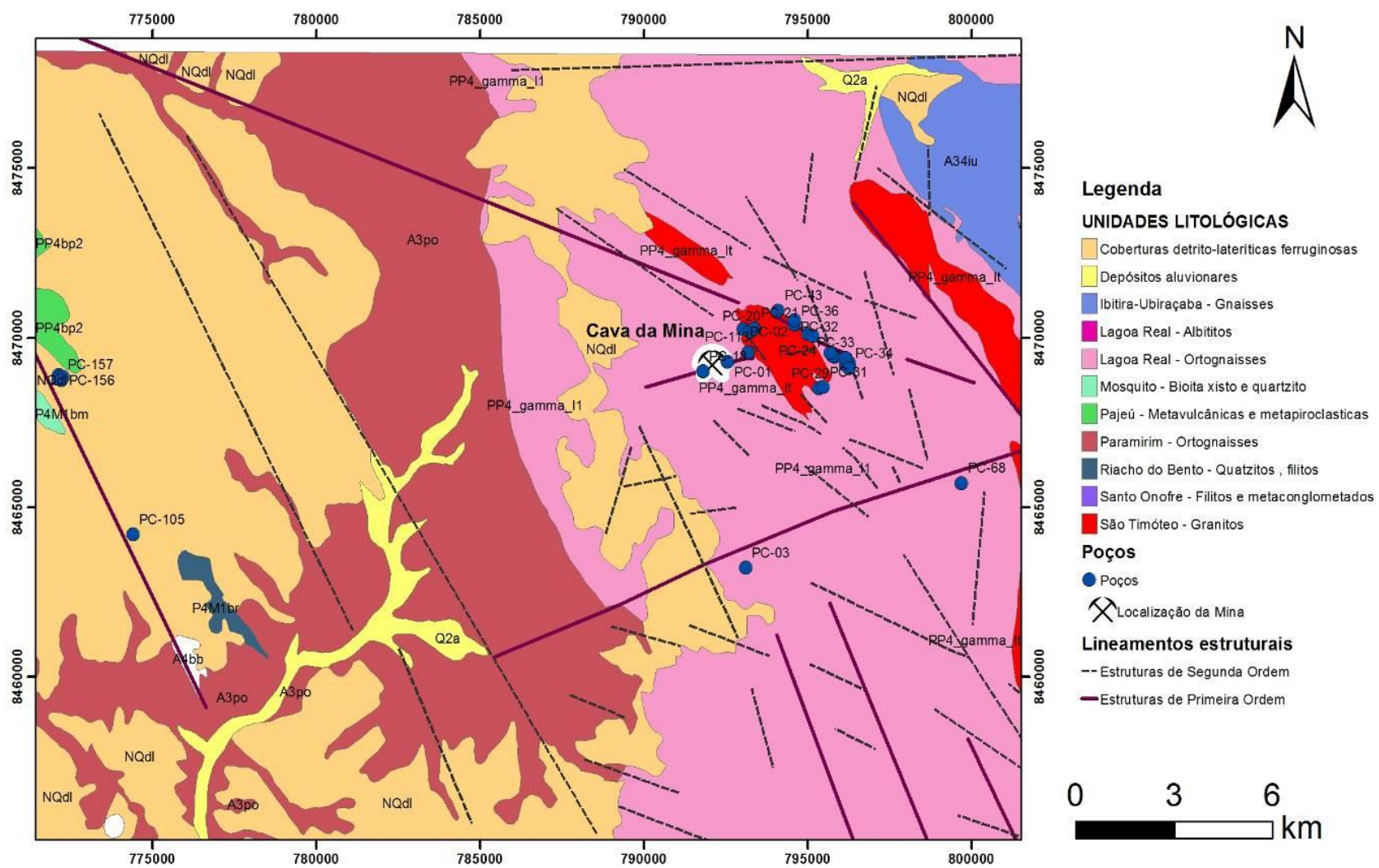

Figura 4.52 - Lineamentos estruturais identificados baseados no Modelo Digital do Terreno (MDT/ASTER), obtido com posição de luz a N45E e $45^{\circ}$ sob a imagem ASTER GLOBAL DEM, consultado em 25/07/2015 através do site do Serviço Geológico Americano (USGS).

Nesse sentido, depreende-se desses resultados que as descontinuidades compreendem o arcabouço estrutural do sistema aquífero, por onde a água flui e é armazenada. Os poços perfurados que não atravessam essas estruturas, ou que encontram descontinuidades rasas, próximas a intercepção com a topografia apresentam-se secos ou com vazões muito reduzidas. A caracterização estrutural demonstrou que esse aquífero tem capacidade de armazenar água até profundidades de 150 metros, de acordo com a exposição de afloramentos e descrições de furos de sondagem. Todavia, a distribuição da comunicação dessas descontinuidades não se mostrou fator preponderante para a homogeneização das concentrações dos parâmetros químicos analisados. Nesse caso, a composição das rochas se revelou fator fundamental. Ainda, a influência do clima semiárido atua no aumento dos teores totais de sais dissolvidos, principalmente em se tratando do cloreto, devido aos longos períodos de seca aos quais toda a região é comumente submetida. 
O teor total de sais dissolvidos já se apresentava em concentrações elevadas, antes do início da atividade de mineração. O mesmo ocorre no caso dos radionuclídeos, em especial o urânio. Além do background já ser elevado, considerando que se trata de região naturalmente anômala, alguns poços apresentam valores de radioatividade bem mais altos. Porém, esses teores estão ligados a natureza da rocha onde o poço está instalado, uma vez que não há indícios de ligação entre esses poços anômalos, e também não há indicadores de comunicação entre eles e os demais poços circunvizinhos, cujos valores encontram-se dentro do background. 


\section{CAPÍTULO V}

\section{MODELO CONCEITUAL E PROPOSTA PARA GESTÃO DO SISTEMA}

\subsection{Modelo Conceitual de Fluxo}

Considerando a determinação física do sistema aquífero, proposta no Capítulo 3, bem como as contribuições da caracterização hidroquímica realizada no capítulo 4, pode-se sintetizar a compreensão do aquífero fraturado analisado.

Na Figura 5.1 está representado, de forma esquemática, os tipos de fluxo associados as descontinuidades que compõem o sistema aquífero. Especialmente em relação a família de estruturas com mergulho sub-horizontal, pode-se visualizar a interferência que estas exercem, comunicando as demais estruturas e permitindo a existência de fluxo e acumulação de água. $A$ Foto 1 na Figura 5.1 exemplifica este tipo de fluxo através de fratura de alívio, pois mostra de forma evidente a existência de fluxo ligado as descontinuidades sub-horizontais. Ainda, consoante o poço 1 presente no bloco diagrama, entende-se que a ocorrência da água explorada refere-se àquela vinculada a zona de descontinuidades sub-horizontal, cuja a área de recarga pode estar há grandes distâncias e ocorrer pela infiltração da água de precipitação em fraturas de elevado ângulo de mergulho que interceptam a superfície.

A Foto 2 na Figura 5.1 retrata as estruturas mais penetrativas, notadamente a família com mergulho para NE. Em decorrência de apresentarem as maiores persistências, esse grupo específico de descontinuidades atua de forma importante na recarga no aquífero, permitindo que a água infiltrada alcance maiores profundidades, e apresente fluxo lateral na medida em que são interceptadas por estruturas sub-horizontais.

Um exemplo de zona de isolamento de fluxo dentro do sistema aquífero pode ser exemplificado pelo Poço A, na Figura 5.1, em que esta estrutura hidráulica, não interceptou estruturas com acúmulo e transmissão de água, resultando em um poço seco.

Ao longo do Riacho das Vacas (Figura 5.2), constatou-se que os poços produtores concentraram-na margem nordeste, enquanto os poços secos predominaram na margem sudoeste. A correlação entre as famílias de estruturas com a topografia revela que, o grupo de descontinuidades mais penetrativas tem mergulho no mesmo sentido do declive topográfico da encosta (Poço A). O fluxo conectado pelas estruturas sub-horizontais logo é descarregado na superfície, quando a topografia intercepta essas descontinuidades. Por outro lado, na margem nordeste, a família NE mergulha no sentido contrário ao talude (Poço B). Nesse caso, ainda que as estruturas sub-horizontais direcionem parte da água para a direção do Riacho das Vacas, as estruturas com mergulho para NE proporcionam regiões com maior acúmulo e circulação de água. 


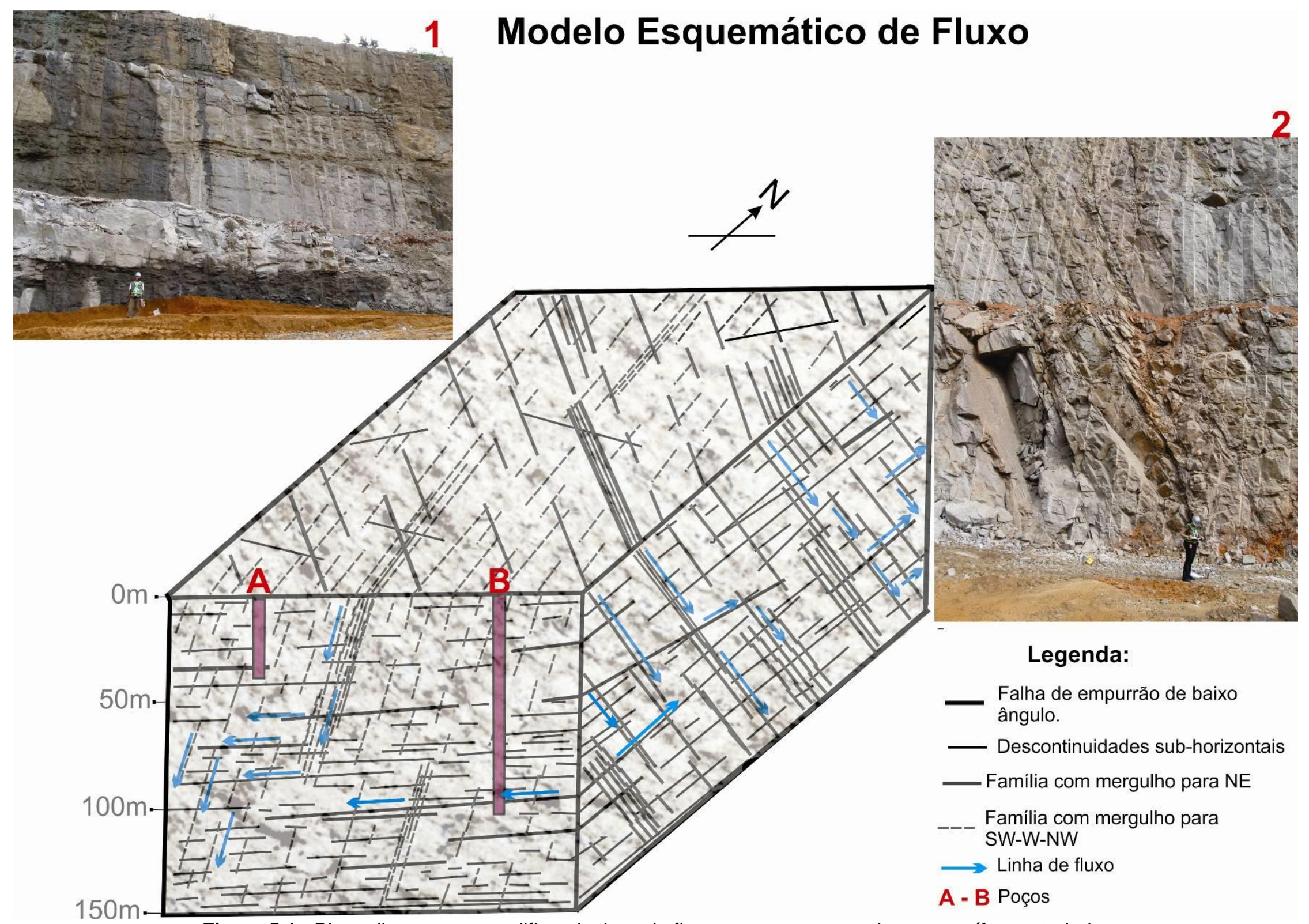

Figura 5.1 - Bloco diagrama exemplificando tipos de fluxo que ocorrem no sistema aquífero estudado. 


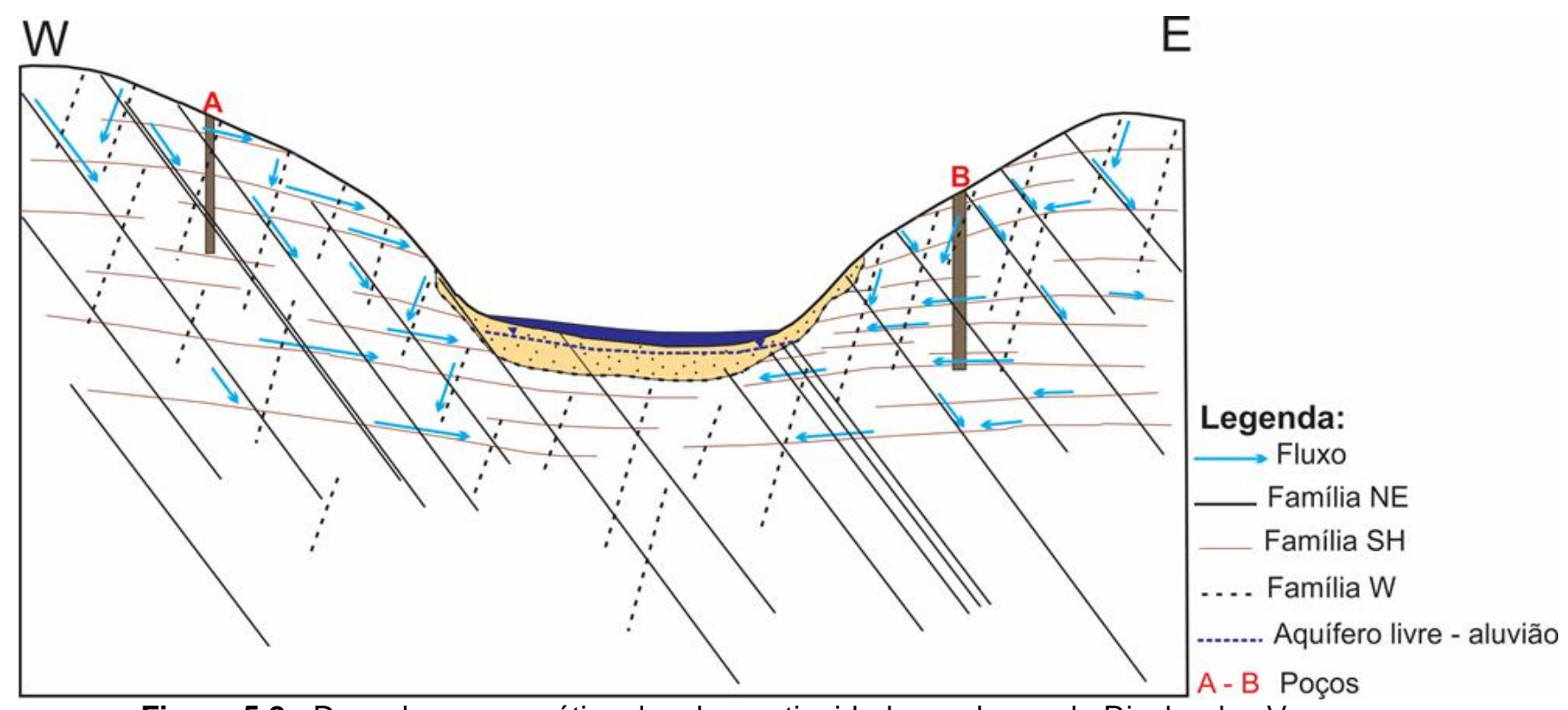

Figura 5.2 - Desenho esquemático das descontinuidades ao longo do Riacho das Vacas.

O fluxo no maciço é condicionado à intersecção de sistemas de descontinuidades. Quando as fraturas sub-horizontais são mais penetrativas há maior possibilidade de escoamento em maior volume de aquífero, ampliando a transmissividade o meio. Quando as fraturas subhorizontais são pouco penetrativas ou ausentes há o isolamento do fluxo, sendo o aquífero mais compartimentos em blocos determinados por grandes zonas com fraturas verticais abertas. Nos casos em que os maciços apresentam baixa densidade de fraturas de todas as famílias ocorre a condição de não fluxo, representando casos em que os poços são secos.

O estudo em uma cava com profundidade da ordem de 150 metros é uma oportunidade para se verificar a presença de fluxo a maiores profundidades. Este dado diverge do senso comum de que nos aquíferos fraturados do cristalino do semiárido brasileiro não há possibilidade de entradas d'água a maiores profundidades e abre a possibilidade para o desenvolvimento de pesquisas para prospecção de estruturas abertas ais abertas.

\subsection{Propostas para Gestão dos Sistemas Aquíferos}

A região estudada apresenta características próprias que tornam os recursos hídricos subterrâneos ainda mais importantes, em comparação a outras regiões do país. Esses fatores tanto promovem quanto agravam os conflitos pelo uso da água e acarretam consequências socioeconômicas. A falta de estudos e acesso a informação favorece um ambiente de vulnerabilidade da população. Na busca por soluções tenta-se enumerar os agentes que geraram os problemas, antes de diagnosticar suas causas. Nesse sentido, o objetivo desse capítulo é identificar a natureza dos problemas que afetam os aquíferos e apontar, dentro do possível, medidas para saná-los.

De acordo com os estudos realizados na área, bem como baseado no cenário socioambiental, político e econômico, podem-se relacionar os seguintes fatores, responsáveis 
pelos conflitos relacionados aos recursos hídricos subterrâneos da região:

a) Clima semiárido $\rightarrow$ déficit hídrico $\rightarrow$ salinização das águas;

b) Background elevado para cálcio - sódio - sulfato - cloretos;

c) Contaminação por nitrato;

d) Zonas de estagnação do fluxo no aquífero;

e) Anomalias naturais de urânio;

f) Conflitos pelo uso da água;

g) Falta de reservatórios de superfície;

i) Risco potencial de contaminação nas áreas de lavra de Urânio

\subsubsection{Diagnóstico dos Problemas}

\subsubsection{Clima Semiárido $\rightarrow$ Déficit Hídrico $\rightarrow$ Salinização das Águas}

O fato de a região estar inserida no contexto do clima semiárido significa que a estação chuvosa ocorre de forma curta (não mais que quatro meses ao ano) e ainda é muito incerta (podem ocorrer seguidos anos com precipitação inferior à média histórica). Na maior parte do ano há déficit hídrico, grande parte dos rios apenas apresenta fluxo no período chuvoso e a população é fortemente dependente da água subterrânea. Além disso, a concentração de sais, que já é naturalmente alta, sofre incremento progressivo nos períodos de estiagem. Como resultado, em certos locais as águas podem apresentar-se impróprias para finalidades de uso mais nobres, tais como consumo e higiene humana. Ainda, considerando que a vocação econômica do município de Caetité é a agricultura familiar, os longos períodos de seca determinam o insucesso das atividades agrícolas e pecuárias e colocam em risco a subsistência das famílias.

Diferente de outras regiões do nordeste do Brasil, submetidas ao mesmo clima, na área em estudo não se observam muitos açudes para armazenamento de água superficial.

No que se refere ao abastecimento público identificou-se, durante as atividades de campo, que dois programas do governo sobressaíram com resultados positivos. O primeiro refere-se ao projeto do Ministério do Desenvolvimento Social e Combate à Fome - MDS, por meio da Secretaria Nacional de Segurança Alimentar e Nutricional - SESAN, que desde 2003 financia a construção de cisternas. Trata-se de uma tecnologia simples e de baixo custo, na qual a água da chuva é captada do telhado por meio de calhas e armazenada em um reservatório de 16 mil litros, capaz de garantir água para atender as famílias e atenuar a falta de água durante o período de estiagem. O segundo aborda a construção de poços para captação de água subterrânea, iniciativa de diversos programas do governo, de entidades não governamentais e dos próprios moradores. Principalmente nos vales, esses poços têm sido usados, tanto para abastecimento, quanto para irrigação de pequenas áreas destinadas ao cultivo de legumes, hortaliças e outras culturas. 


\subsubsection{Background alto para Cálcio - Sódio - Sulfato e Cloretos}

As concentrações de sais mais elevadas, como ocorre naturalmente na região, bem como os pontos de estagnação, onde esses teores são ainda maiores podem resultar em águas salobras, impróprias para o consumo humano e animal. Num contexto socioambiental onde os recursos hídricos são tão fundamentais a subsistência da população, o aproveitamento dessas águas torna-se imprescindível, para promover geração de renda e melhoria da qualidade de vida.

Além dos teores anômalos destes íons, o elevado TDS (total de sais dissolvidos) também é responsável pela limitação dos usos (para fins nobres) de águas oriundas de poços tubulares que captam águas exclusivamente de aquíferos fraturados.

\subsubsection{Contaminação por Nitrato}

Os teores de nitrato encontrados na região são consideravelmente elevados. Da observação durante as atividades de pesquisa realizadas em 2014, notou-se a criação de animais bovinos (em pequenas regiões) e ovinos (de forma mais generalizada), como também uso de pesticidas em restritas zonas de plantação, principalmente nos vales, sendo considerada a principal fonte de contaminação por nitrato. Também se deve considerar, embora em menor grau, as práticas resultantes da má construção, conservação ou implementação em locais pouco adequados de fossas. O tipo de poluição resultante é, sobretudo, microbiológica, mas também se traduz por aumento de nitratos e de outros compostos (como sódio e cloreto). Sendo assim, no ambiente rural identifica-se contaminação pontual, todavia, disseminada por toda a área.

\subsubsection{Existência de Zonas de Isolamento nos Aquíferos}

A identificação de zonas de isolamento, onde claramente não há indícios de comunicação no aquífero, propicia aumento das concentrações de sais e radionuclídeos, especialmente se associado a pontos onde existem bolsões de carbonatos. Nessa lógica, caso um poço seja perfurado em zonas de estagnação, os teores de sais e de isótopos radioativos encontrados poderão ser bastante anômalos, em relação ao background geral.

Como são situações isoladas no domínio dos aquíferos fraturados esta feição pode ser crítica em alguns poços e não representar qualquer risco em outros poços construídos em uma mesma propriedade rural.

\subsubsection{Anomalias Naturais de Urânio}

Esse é um ponto muito sensível, que tem sido objeto de sérios conflitos em toda a região. Afinal, qual a verdadeira causa que explica os teores de urânio diagnosticados nos poços da região? Para alguns essa pergunta tem apenas uma resposta, a atividade de mineração. Entretanto, não se pode descartar outra possibilidade para explicar as anomalias regionais em urânio. 
A INB ocupa uma área restrita aos limites do Complexo Mínero-industrial, onde as principais fontes de contaminação são áreas da cava da mina, pilhas de estéreis de mineração, pátio de estocagem de minérios e bacia de rejeitos. De acordo com Simões Filho et al. (2008), os rejeitos provenientes da primeira etapa do ciclo do combustível nuclear são caracterizados por possuírem um volume inversamente proporcional à concentração de urânio minerada. A composição química dos rejeitos gerados na mineração e beneficiamento do urânio consiste basicamente de materiais inertes (sílica, alumina, etc.) associados a resíduos químicos (ácidos ou alcalinos) provenientes do tratamento físico (britagem e moagem) e químico (extração química) aos quais o minério é submetido. Como todos os efluentes, e do mesmo modo o escoamento superficial são drenados e reintroduzidos no processo, ou acumulados em piscinas de contenção, a maior fonte de contaminação para as águas subterrâneas são as cavas, onde a água das chuvas pode lixiviar os albititos mineralizados e recarregar diretamente o aquífero (a partir de descontinuidades expostas).

Em relação a concentração de urânio encontrada nas águas subterrâneas, deve-se considerar que:

a) A estação chuvosa concentra-se em quatro meses ao ano e na maior parte do tempo há déficit hídrico. Caso as cavas fossem responsáveis por alguma contaminação, isso estaria intrinsecamente associado ao período chuvoso.

b) Em toda a região, como pode ser observado na Figura 2.1, encontram-se albititos mineralizados em urânio. Estas rochas não estão restritas a área da INB, ao contrário, estão largamente distribuídos, compondo uma grande região anômala, onde as rochas (gnaisses do Complexo lagoa Real) apresentam concentrações naturais elevadas em urânio.

c) De acordo com os dados produzidos, os poços com as maiores anomalias de urânio (PC01, PC-09 e PC-68) não estão conectados entre si, tanto do ponto de vista estrutural como hidroquímico. Considerando o diagnóstico produzido no capítulo anterior, poços adjacentes apresentam teores abruptamente inferiores àqueles constatados nos poços anômalos.

Desta forma, entende-se que as concentrações anômalas de urânio observadas em determinados poços refletem a geoquímica da rocha, que naturalmente é enriquecida nesse elemento radioativo. Trata-se de uma grande região anômala para este radioisótopo e é esperado se encontrar nas águas subterrâneas, que lixiviam essas rochas, o reflexo dessa anomalia. Assim, pode-se afirmar de forma categórica que as anomalias de urânio nos solos e nas águas subterrâneas são decorrentes de processos naturais de acúmulo por interação águarocha e pelo intemperismo.

\subsubsection{Prioridades de Uso $\rightarrow$ Abastecimento Público}

O principal conflito de interesse observado na região refere-se a finalidade de uso da água para fins de consumo humano, uso na irrigação e industrial. Ainda, alguns poços não podem ser destinados ao consumo humano, considerando que as concentrações de sais e 
especialmente de nitrato apresentam-se bastante altas. No meio urbano há sistema de abastecimento público, entretanto, na zona rural predominam os poços e as cisternas para captação de água das chuvas.

No que se refere a irrigação e dessedentação de animais, essas finalidades competem com o consumo e higiene humana. No caso da atividade de mineração de urânio, a INB utiliza água dos poços instalados dentro dos limites de sua propriedade, assim como compra água envasada para consumo dos funcionários e, diante disso, não compete com as demais finalidades de uso. Ressalta-se, porém, que outras atividades de mineração são desenvolvidas na região, como é o caso da mineração de ferro pela Bahia Mineração (Bamin) e da mineração de manganês pela BAGESA Fertilizantes e Mineração Ltda.

\subsubsection{Falta de Reservatórios de Superfície}

A região em estudo, em comparação com outras áreas do semiárido do nordeste do Brasil, apresenta carência de reservatórios de superfície para armazenamento de águas de escoamento superficial. As barragens ou açudes como são conhecidos na região representam importante volume de água para serem utilizadas nos amplos períodos de recessão das chuvas. Estas águas são prioritariamente utilizadas para dessedentação de animais e para irrigação de pequenas culturas em geral plantadas nas adjacências dos próprios açudes.

Considerando que grande parte das águas das chuvas são "perdidas" para o escoamento superficial, o armazenamento mais eficiente dessa água pode ser feito através de barragens construídas nos vales mais encaixados, que propiciam reservatórios estreitos e com maior profundidade da lâmina d'água.

\subsubsection{Risco Potencial de Contaminação nas Áreas de Lavra de Urânio}

O risco de contaminação do meio ambiente como um todo (ar, água superficial, água subterrânea, solos, etc.) pela atividade de mineração de urânio não pode ser totalmente desconsiderado. Ventos podem elevar particulados a partir das áreas de rejeitos. $\mathrm{A}$ água de escoamento superficial pode sair dos limites das áreas de lavra e de metalurgia é alcançar áreas externas. Há risco de contaminação durante o transporte dos insumos e dos produtos oriundos da planta de tratamento, a partir de eventuais acidentes com caminhões e máquinas. Enfim, o risco de contaminação pela atividade de mineração não pode ser desconsiderado, sendo sua minimização fortemente dependente da efetividade das medidas de mitigação e de controle ambiental desenvolvidas.

\subsubsection{Propostas para Gestão do Sistema de Abastecimento}

Uma série de ações pode ser considerada como importante para a gestão do sistema de abastecimento e ampliação da segurança hídrica da população residente na região em estudo, 
incluindo: construção de poços tubulares, ampliação da rede de cisternas para acumulação de águas de chuva, uso de dessalinizadores, controle da qualidade das águas (principalmente para TDS, radioatividade e nitrato), construção de reservatórios de superfície, desenvolvimento de projetos de recarga artificial dos aquíferos, dentre outros.

Dentre os projetos implantados pelo poder público, alguns obtiveram êxito e outros não alcançaram os resultados esperados.

A construção de poços tubulares contribuiu para a melhoria da qualidade de vida de diversas comunidades, propiciando abastecimento para consumo humano, irrigação de plantações e criação de animais (Figura 5.3). O desenvolvimento dessas atividades gera emprego e renda, incrementando a economia dos municípios com o fornecimento de legumes, verduras e carne sem a necessidade de grandes deslocamentos, o que torna o frete mais barato, e por conseguinte, minimiza o custo ao consumidor final.

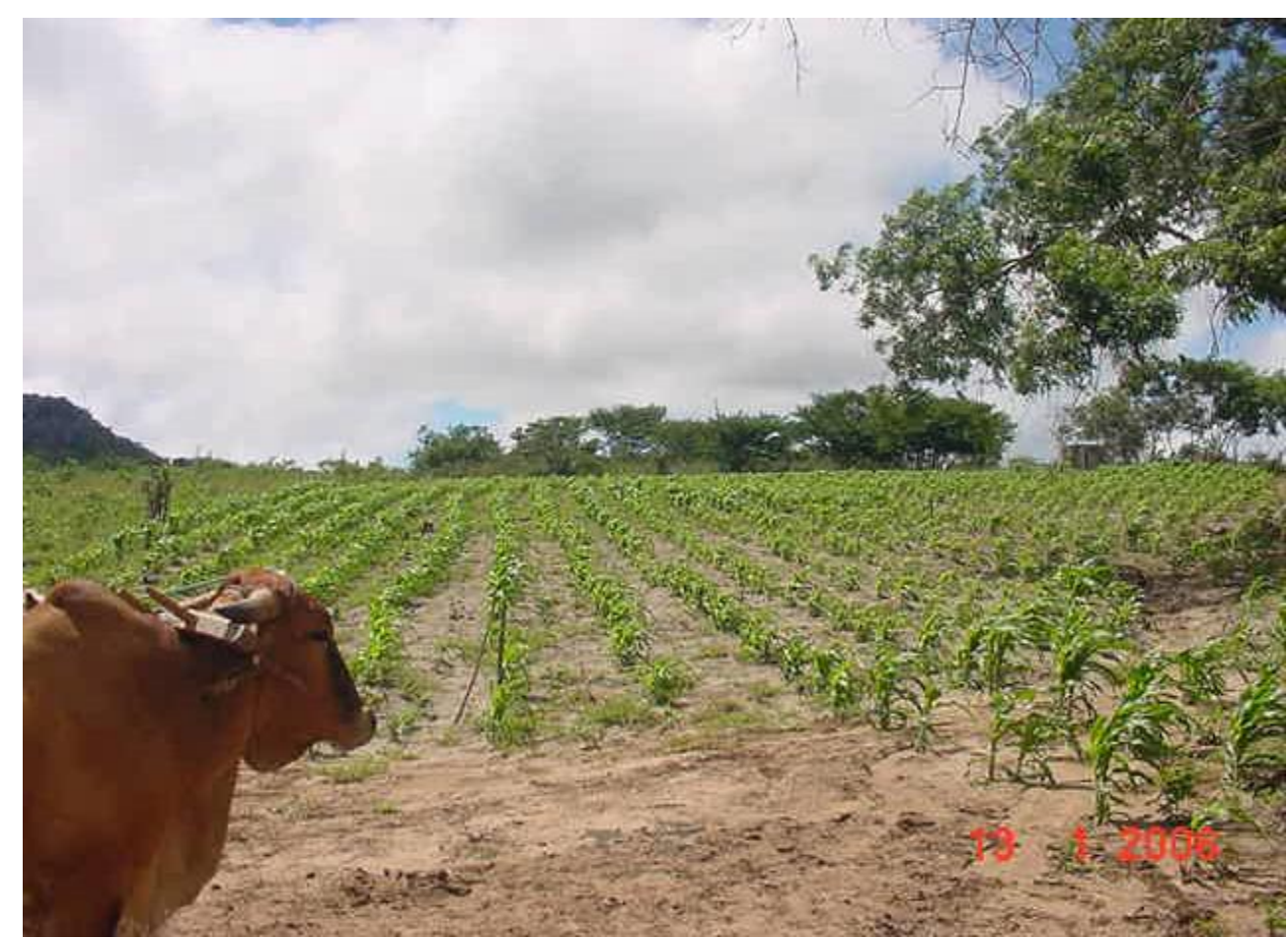

Figura 5.3 - Foto da região de São Timóteo, onde a água subterrânea captada a partir de poços tubulares profundos é usada para o desenvolvimento da agricultura familiar e criação de animais.

A construção de cisternas para captação da água de chuva (Figura 5.4) também pode ser citada como exemplo de projeto que surtiu efeitos positivos como fonte alternativa de abastecimento. A população rural utiliza essa água para consumo e higiene humana. Uma pesquisa realizada pela Federação Nacional dos Bancos (FEBRABAN) revelou que, num universo de 140 mil pessoas beneficiadas com uso de água de cisternas, a incidência de verminoses e asma diminuiu respectivamente $4,2 \%$ e 3,9\%, (ASABRASIL, 2015). 


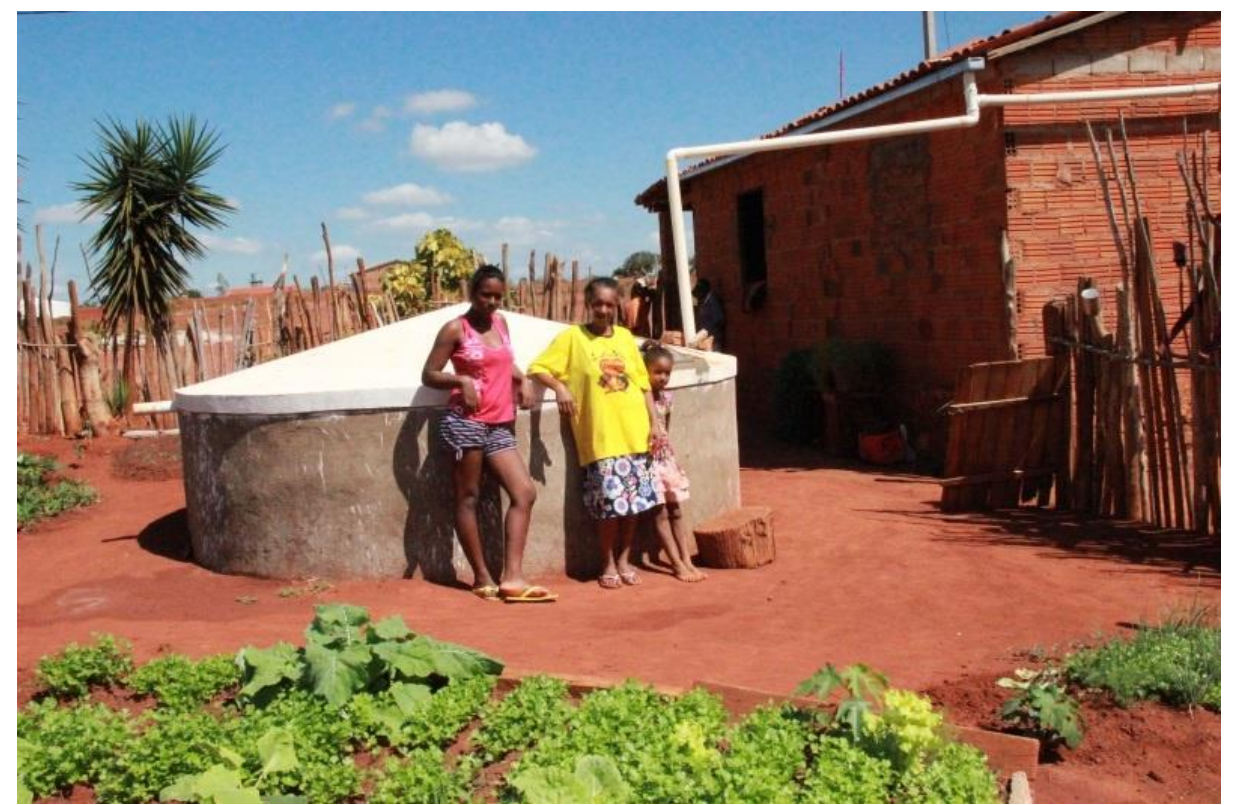

Figura 5.4 - Foto de cisterna para captação da água de chuva no semiárido nordestino (Fonte: Irecê Repórter, 2015).

Alguns projetos não lograram êxito, principalmente como resultado da falta de planejamento. Na região estudada pode-se citar a implantação de dessalinizadores como exemplo desses programas. Como resultado do processo de osmose reversa utilizada nos dessalinizadores, parte da água tratada é excelente para o consumo, e o restante fica extremamente concentrado em sais e deveria ser reutilizada em alguma atividade. Entretanto, parte dos equipamentos está quebrada e não há manutenção, e os poucos que funcionariam estão inutilizados pela falta de fornecimento de membranas. Ainda, dentre os dessalinizadores visitados, constatou-se não haver local para descarte da água concentrada em sais, e isso é realizado diretamente na superfície, ao lado do equipamento. Esse rejeito infiltra no solo e recarrega o aquífero, aumentando progressivamente o processo de salinização das águas subterrâneas.

Em se tratando da construção de poços e cisternas recomenda-se a ampliação desses projetos, já no caso dos dessalinizadores (Figura 5.5), tecnologia que pode contribuir como fonte de abastecimento para a população, a solução deve focar na manutenção dos equipamentos, recuperando aqueles que apresentam defeitos e garantindo o fornecimento das membranas. Também deve-se assegurar que a água residual seja reaproveitada. Existem opções de reuso que além de evitar o agravamento do processo de salinização criam novas opções de geração de renda para a comunidade. Segundo Soares et al. (2006), nos países desenvolvidos, o rejeito está sendo transportado para os oceanos, injetados em poços de grande profundidade ou lançado na rede pública de esgotos. No Brasil, alternativas promissoras consistem no desenvolvimento da aquicultura, com a criação de tilápias e camarões em viveiros. Além da geração de emprego e renda capaz de promover autossuficiência ao dessalinizador, ainda aumentaria a oferta de proteína de baixo custo e proveria a capacitação da mão-de-obra da região. 


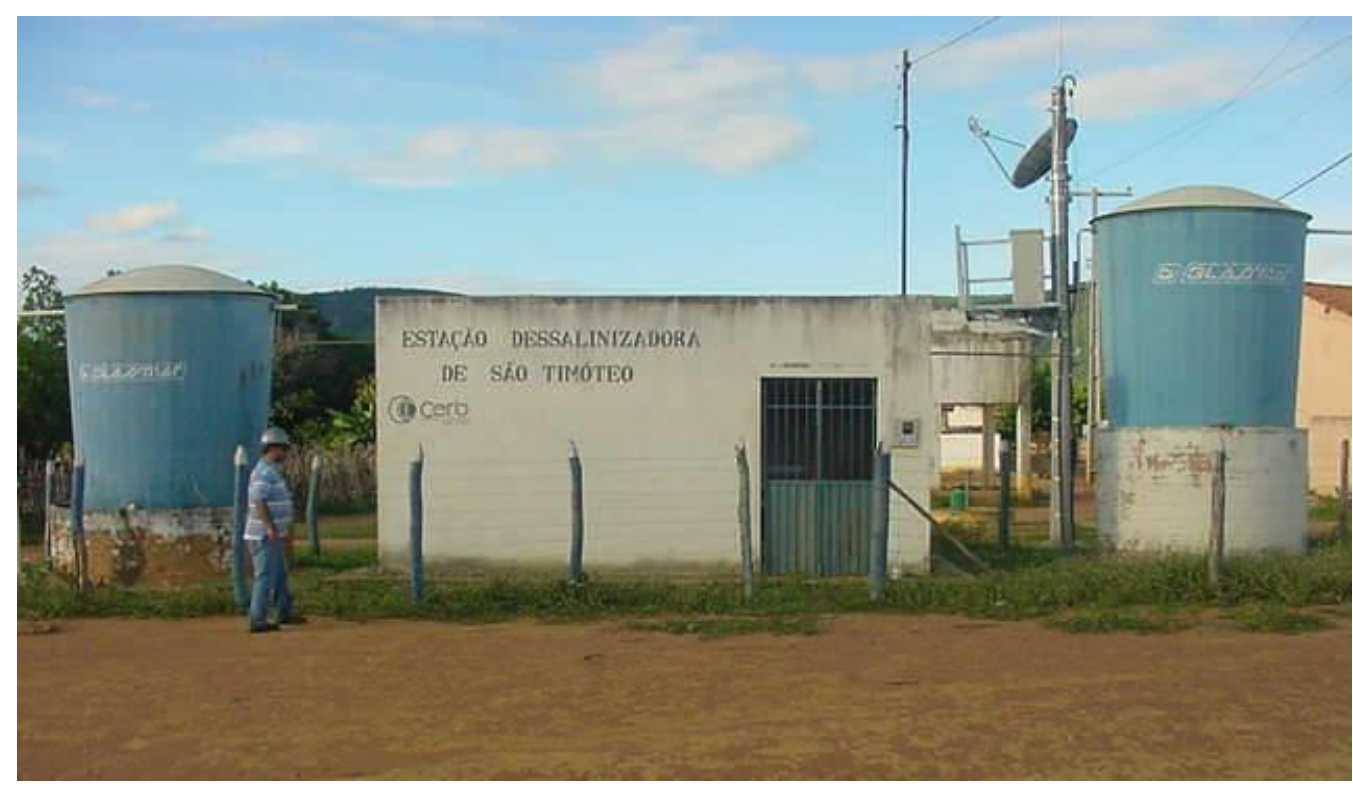

Figura 5.5 - Unidade dessalinizadora de São Timóteo.

Dentre os problemas detectados no decorrer do desenvolvimento desta dissertação, no caso do déficit hídrico, uma alternativa viável para aumentar a disponibilidade de água é a recarga artificial de aquíferos. Considerando o tipo de aquífero encontrado na região (fraturado), métodos que consistem em criar estruturas superficiais (recarga por irrigação, por alagamento, construção de valas e canais ou desvio de rios) não apresentam a mesma eficiência, em comparação a poços de injeção profunda. Além disso, tendo em vista o processo de salinização, a percolação dessas águas pelo solo acarretaria em dissolução de sais e infiltração dessa água salobra. Os poços de injeção constituem uma técnica de recarga artificial onde a água é bombeada diretamente nos poços. A tecnologia para implantação e os requisitos de qualidade da água de recarga são mais exigentes do que nos sistemas de recarga à superfície. Sendo assim, utiliza-se água pluvial coletada no telhado das casas, graças a sua melhor qualidade em comparação ao escoamento superficial. A desvantagem dessa técnica são os custos envolvidos, que atualmente são significativamente elevados.

Em se tratando dos poços construídos em anomalias de urânio ou nas zonas de estagnação, que normalmente apresentam atividade de isótopos radioativos e/ou concentrações de sais mais elevadas, para os poços que já existem e aqueles que serão perfurados, o controle da qualidade da água é imprescindível. Análises periódicas e que diagnostiquem as variações hidroquímicas do aquífero, de acordo com a sazonalidade, e incluam as atividades dos radioisótopos, indicariam para qual finalidade de uso determinado poço se destina, se há viabilidade de implantar sistema de alternância do bombeamento - não explotar a água de um determinado poço, num período no qual o teor de sais supera o limite permitido para aquela finalidade de uso permitida-, ou mesmo se um ponto de interferência deve ser tamponado. Já no que se trata da construção de novos poços, o local e o tipo petrográfico encontrado já indica o que esperar da qualidade da água. Como se observou dos diagramas de Stiff, todos os poços 
instalados nos granitos e gnaisses na região apresentam teores de sais mais elevados, principalmente cloretos e sódio. No caso de interceptar albititos, a possibilidade de deparar-se com concentrações anômalas de urânio nas águas deve ser considerada. Sendo assim, planejar novos poços com base na geologia da região e analisar o material rochoso coletado durante a perfuração auxiliam na previsão do que esperar da qualidade da água.

No caso das concentrações de nitrato detectadas, o critério de poluição é relativo, pois a qualidade da água dependerá de sua aplicabilidade. No que se refere ao padrão de potabilidade para consumo humano, estabelecido pela Portaria no 2.914 do Ministério da Saúde,o padrão de potabilidade é definido como o conjunto de valores permitidos, dos parâmetros físico-químicos, que definem a qualidade da água destinada ao consumo humano. A água potável, por sua vez, é aquela que atende ao padrão de potabilidade e não oferece riscos à saúde. Nesse caso, as supracitadas análises químicas periódicas das águas dos poços possibilitariam a delimitação de regiões com diferentes níveis de concentração de nitrato, identificando as áreas mais vulneráveis, as finalidades de uso possíveis, e principalmente, possibilitando a identificação das fontes de contaminação e o diagnóstico de um problema de caráter socioambiental. Trata-se da falta de um sistema de esgotamento sanitário que atenda essa população rural, de áreas pobres do país. Na impossibilidade de implantação de rede coletora de esgotos, alternativas precisam ser analisadas e praticadas, tais como a construção de sistemas fossa-filtro-sumidouro, de tal modo que esses lançamentos gerem menos impactos ao meio ambiente e, em especial diminuem a deterioração das águas subterrâneas, fato que amplia os problemas de escassez de água com qualidade para serem consumidas pelo homem.

Uma ação que em geral deve ser desenvolvida pelos poderes públicos federal, estadual e municipal é a construção de mais reservatórios eficientes de superfície compondo açudes com capacidade de acumulação de expressivos volumes de água de escoamento superficial. Os trabalhos de campo mostraram vários pontos em locais com relevos mais acidentados com a presença de ombreiras nos vales mais encaixados que permitem a instalação de reservatórios com elevada eficiência, isto é, grande profundidade e menos área, para minimizar as perdas pela evaporação direta.

Em casos específicos, ao longo dos principais aluviões, não se pode descartar a possibilidade de instalação de barragens subterrâneas que também podem ser responsáveis pela acumulação e reserva de significativos volumes de água, com mínimo risco de perda por evaporação e salinização. Esse tipo de reservatório compreende uma alternativa econômica e simples de ser executada. Um exemplo simples é a impermeabilização utilizando lonas, onde se escava uma sessão do leito do rio e instala-se essa lona, alcançando o substrato aproveitando o próprio material escavado para fixá-la.

Por fim, para se minimizar risco de contaminação diretamente pela atividade de mineração e metalurgia de urânio devem-se manter as ações já desenvolvidas. Dentre as práticas a serem mantidas e intensificadas, se incluem: eliminação total do fluxo de escoamento 
superficial para áreas externas às de lavra e de tratamento de minério; manutenção dos controles de acesso de pessoas, dar continuidade ao monitoramento de parâmetros de qualidade das águas e ar; ampliação dos controles de segurança no transporte de substâncias consideradas perigosas e demais ações ambientais. 


\section{CONSIDERAÇÕES FINAIS E CONCLUSÕES}

Esta Dissertação de Mestrado traz uma contribuição inédita ao entendimento do sistema aquífero da região. Trata-se do modelo conceitual proposto para o aquífero, a partir da caracterização das descontinuidades que o compõem. O levantamento quali-quantitativo das estruturas, analisadas independente de sua gênese, mas com foco na sua contribuição à acumulação e fluxo de água, representa um grande passo rumo ao conhecimento do comportamento desse aquífero em meio fraturado, situado em região de clima semiárido.

Deve-se ressaltar também a metodologia utilizada, que consistiu em dar uma aplicação distinta a técnica de caracterização de estruturas concebida para ser aplicada a projetos de engenharia. Desse modo, todas as estruturas que rompem a continuidade do maciço rochoso (e por isto denominadas de descontinuidades), independentemente de serem falhas, juntas, zonas de cisalhamento ou a própria foliação da rocha, desde que tenham importância na composição do aquífero, são diagnosticadas e analisadas.

Existem poucos afloramentos viáveis para esse tipo de levantamento na região, que requer exposição do maciço, e nesse caso essa parte do trabalho se concentrou dentro dos domínios físicos da INB, aproveitando a exposição de rochas das cavas da mineração, bem comodo canal de desvio das águas de escoamento superficial.

Sobre o sistema aquífero, pode-se afirmar que é um sistema livre e aberto, porém, apresenta pontos de isolamentode fluxo sem comunicação com a vizinhança. Existem três famílias de descontinuidades principais que o compõem, as famílias NE, SW-W-NW e Subhorizontal. A primeira e a segunda são responsáveis pela recarga, já a terceira responde pela interconexão de todo o sistema.

A parte superior do maciço apresenta-se com volume maior de anisotropias, pouco espaçadas e com persistências mais baixas, formando uma zona bastante fragmentada. Com a profundidade, predominam estruturas mais penetrativas e com espaçamentos maiores entre si, representadas principalmente pela família NE. Essas descontinuidades têm papel fundamental na recarga dessas zonas mais profundas, e a existência de fluxo d'água. Ainda existem zonas de cisalhamento que, quando não preenchidas, apresentam aberturas que constituem caminhos preferenciais ao fluxo, em virtude de representarem zonas penetrativas no maciço.

As estruturas sub-horizontais persistem até a profundidade de 150 metros, garantindo a interconexão do sistema aquífero em toda a massa de rochas analisada. Este dado indica que o senso comum de que a profundidade máxima dos poços em aquíferos cristalinos do semiárido do nordeste deve ser inferior a 100 metros pode estar equivocada. Há possibilidade real de que, 
pelo menos ao longo das principais zonas de cisalhamento, ocorram poços com entradas d'água a maiores profundidades (como no caso estudado).

A importância das anisotropias sub-horizontais é evidenciada na cava da Mina de Urânio que mostra percolação de água mais intensa e evidente que as estruturas verticais ou de elevado ângulo.

O modelo conceitual do aquífero estudado pode ser considerado como um tipo fraturado clássico, pois o conjunto de rochas não apresenta nenhuma porosidade intergranular ou espaços matriciais residuais, por se tratar de rochas metamórficas de alto grau ou rochas plutônicas.

A distribuição da comunicação dessas descontinuidades não se mostrou fator preponderante para a homogeneização das concentrações dos parâmetros químicos analisados. Nesse caso, a composição das rochas se revelou fator fundamental na determinação do caráter hidroquímico das águas subterrâneas. As rochas graníticas e gnáissicas mapeadas na região apresentam o mesmo padrão químico, cujo background encontrado para o sódio, cloretos, cálcio e sulfato é naturalmente elevado, especialmente nos dois primeiros íons citados. Já os quartzitos e rochas metapiroclásticas distribuídas regionalmente, retratam comportamento totalmente distinto, sendo empobrecidas em íons e em atividade radioativa.

O confronto entre as concentrações de cálcio, sódio e sulfato, bem como a atividade do urânio com o Mapa de Lineamentos Estruturais (em escala 1:230.000), demonstrou que essas estruturas regionais não são preponderantes na distribuição das concentrações dos parâmetros físico-químicos analisados.

O teor total de sais dissolvidos já se apresentava em concentrações elevadas, antes do início da atividade de mineração. O mesmo ocorre no caso dos radionuclídeos, em especial o urânio. Além do background já ser elevado, considerando que se trata de região naturalmente anômala, alguns poços apresentam valores de radioatividade bem mais altos. Porém, esses teores estão ligados a natureza da rocha onde o poço está instalado, uma vez que não há indícios de ligação entre esses poços anômalos, e também não há indicadores de comunicação hidráulica entre eles e os demais poços circunvizinhos, cujos valores encontram-se dentro do background.

A respeito dos cloretos, a influência do clima semiárido atua no aumento dos teores desse sal, devido aos longos períodos de seca, aos quais toda a região é normalmente submetida. A fonte principal é considerada atmosférica, entretanto não se descarta que uma parcela tenha origem a partir da hidrólise de micas (principalmente a biotita), o que resulta em fonte geogênica.

As concentrações elevadas de nitrato não mantêm relação com os tipos rochosos, são intrinsecamente ligadas ao lançamento de esgoto sem tratamento e a dejetos de animais em virtude da pecuária extensiva, desenvolvida na região.

Considerando as concentrações de nitrato, em determinados locais as anomalias de urânio, os pontos de isolamento de fluxo e as altas concentrações de sais, a água dos poços 
existentes e daqueles a serem perfurados deve ser periodicamente analisada com o objetivo de manter o controle sobre a qualidade dos recursos hídricos subterrâneos. A partir dessa avaliação podem ser tomadas medidas para regulamentar a finalidade de uso da água de um determinado poço, por exemplo, ou até mesmo decretar que um poço seja tamponado, caso constate-se contaminação que inviabilize seu uso para qualquer finalidade.

Os resultados obtidos devem ser aplicados para a previsão do fluxo de plumas de contaminação, para locação de novos poços, para locação de sítios de recarga e demais ações para a gestão dos aquíferos fraturados em estudo, especialmente no que se refere ao fechamento da mina, quando findar o bombeamento dos poços e o fluxo da água subterrânea voltar ao estado natural.

Para a localização de seções aquíferas potencialmente produtoras os pontos prioritários para a locação de poços encontram-se nas zonas de intersecção de anisotropias das famílias NE com aquelas associadas à Família SW-W-NW. Como as estruturas sub-horizontais são persistentes até maiores profundidades o sucesso na exploração da água subterrânea é significativamente ampliado.

Especialmente em regiões onde ocorrem rochas cristalinas, no semiárido nordestino, esse estudo demonstra que é viável construir poços mais profundos. Como observado na área da cava, as estruturas sub-horizontais ocorrem em profundidades de até 150 metros, com percolação de água mesmo no período seco do ano.

A fim de reduzir as dificuldades de determinação das estruturas em locais com maior cobertura de solos sugere-se a aplicação de estudos geofísicos. Mesmo os métodos que estudam pequenas profundidades são úteis, uma vez que nas regiões semiáridas as coberturas pedológicas são pouco espessas.

Finalmente, a região analisada oferece bastante motivação para aprofundamento dos estudos. O volume de dados disponível é grande, principalmente tratando-se dos parâmetros físico-químicos. Encoraja-se também a aplicação de diferentes ferramentas para modelagem de aquíferos fraturados, como, por exemplo, de se tratar o aquífero fraturado como um meio fractal. 


\section{REFERÊNCIAS BIBLIOGRÁFICAS}

Ab' Sáber, A. N.1999. Sertões e sertanejos: uma geografia humana sofrida. In: ESTUDOS AVANÇADOS. Dossiê Nordeste seco. São Paulo: IEA/USP, v. 13, n. 36.

Asabrasil, 2015. Ministério reforça parceria para universalizar acesso à água em municípios de Alagoas. Disponível em: <http://www.asabrasil.org.br/imprensa/asa-namidia?artigo_id=1563> Acesso em agosto de 2015.

Bizzi, L. A., Schobbenhaus, C., Vidotti, R. M., Gonçalves, J. H. (eds).2003. Geologia Tectônica e Recursos Minerais do Brasil. $1^{a}$ ed. Brasília: CPRM- Serviço Geológico do Brasil.692 p.ISBN 85-230-0790-3.

Branco, P.M.1979.Dicionário de Mineralogia. Rio de Janeiro: ed.Oficina de textos.254p.ISBN: 9788579751639.

Brito, W., Raposo, C., Matos, E.C. 1984. Os albititos uraníferos de Lagoa Real. In: SBG, Congresso Brasileiro de Geologia, 33, Rio de Janeiro. Anais, p. 1475- 1488.

Caby R. \& Arthaud M. 1987. Petrostrucutural evolution of the Lagoa Real subalcaline metaplutonic complex (Bahia, Brasil). Revista Brasileira de Geociências, 17(4):636.

Camargo, M.B.P.,Camargo, A.P. 1993.Representação gráfica informatizada do extrato do balanço hídrico de Thornthwaite \& Mather. Bragantia, Campinas, v.52, p.169-172.

Cardoso, V. G., Sobrinho, N. M. B. A., Wasserman, M. A. V., Mazur, N. 2009. Geoquímica de radionuclídeos naturais em solos de áreas circunvizinhas a uma Unidade de Mineração e Atividade de Urânio. Rev. Bras. Ciênc. Solo, vol.33 - nº.6, Viçosa. ISSN 0100-0683.

Cetesb (Companhia Ambiental do Estado de São Paulo). 2009. Significado Ambiental e Sanitário das Variáveis de Qualidade das Águas. Disponível em: http://www.cetesb.sp.go v.br/userfiles/file/agua/aguas-superficiais/variaveis.pdf. Acesso em: julho de 2015.

Chaves, A.O. 2013. New geological model of the Lagoa Real uraniferous albitities from Bahia (Brazil).Central European Journal of Geosciences, Vol. 5, Issue 3, p.354-373.

Cordani, U.G., Iyer, S.S., Taylor, P. N., Kawashita, K., Sato, K., Mcreath, I. 1992. Pb-Pb, Rb-Sr, and $\mathrm{K}-\mathrm{Ar}$ sistematic of the Lagoa Real uranium province (south-central Bahia, Brazil) and the Espinhaço Cycle (ca. 1.5- 1.0 Ga). J. Sout. Amer. Eart. Sci.1: 33-46.

Costa P. H. O., Andrade A. R. F., Lopes G. A. C., Souza S. L. 1985. Projeto Lagoa RealMapeamento Geológico 1:25.000. CBPM/NUCLEBRAS/SME, vol. 1, 455p.

Costa, WD. 1965. Resumo Hidrogeológico da Região Centro-Sul da Paraíba. Água Subterrânea, 3: 18-24.

Custodio, E.; Llamas, M. R. 1996. Hidrología subterránea. º ed. Barcelona: Ediciones Omega, $1157 \mathrm{p}$.

Dandenne, M. A., Schobbenhaus, C. 2001. Metalogênese do Brasil. Brasília, Brasília: CPRMServiço Geológico do Brasil., 392p.

Embrapa. 2013. Sistema Brasileiro de classificação de solos. - 3 ed. rev. ampl. - Brasília: Embrapa. 353 p. Disponível em: http://livraria.sct.embrapa.br/liv_resumos/pdf/00053080.pdf. Acesso em dezembro de 2013.

Feitosa, F.A.C., Manoel Filho, J., Feitosa, E.C. Demetrio, J.G.A. (Eds).2008. Hidrogeologia: conceitos e aplicações. Rio de Janeiro: Serviço Geológico do Brasil - CPRM: LABHID, 812 p.

Gabelman J.W. 1977. Migration of uranium and thorium - exploration siguificance. Tulsa, Amer. Assoc. Petro. Geol. Studies in Geology no 3,168 p.

Galuszka, A. 2006. Methods of determining geochemical background in environmental studies. Problems of landscape ecology. Polish association of landscape ecology - Warsaw (in Polish with English summary), vol. 16, n. 1, p. 507-519. 
Geisel Sobrinho, E., Raposo, C. Prates, S.P., Matos, E. C., Alves, J. C. 1980. Jazidas uraníferas de Lagoa Real, Bahia. In: SBG, Congresso brasileiro de Geologia,31. Camboriú, Anais, 3:1499-1512.

Geoservice.2004. Estudo Hidrogeológico ambiental para caracterização do potencial de contaminação de solos e água subterrânea na área da Unidade de Concentrado de Urânio em Caetité. Relatório final, volume I.

Goodman, R.E. Introduction to Rock Mechanics. $2^{a}$ ed. Califórnia: editora John Wiley \& Sons, 1989.

Hayett, A.J., Dyke, C.G. \& Hudson, J.A. 1986. A Critical Evaluation of Basic Concepts Associated with the existence and Measurement of In-Situ Stress. International Symposium on Rock Stresses and Rock Stress Measurements. Stockholm.

Heinrich, E.W. 1966. Mineralogia Y Geologia de las Matérias primas Radiactivas. Editora Omega, Barcelona. Capítulo V, Yacimientos de Pegmatitas Radiactivas, pp.209-248.

Hem, J. D.1985. Study and interpretation of the chemical characteristics of natural water. U.S. Geological Survey: Alexandria, $3^{a}$. ed.

Herget, G. 1988. Stresses in Rock. $1^{\text {a }}$ ed. Rotterdam: editora Balkema.

Hoek, E. \& Brown, E.T. 1988. Empirical strength criterion for rock masses. J. Geotech. Engng Div., ASCE 106(GT9), 1013-1035.

Indústrias Nucleares do Brasil (INB). Ciclo do Combustível Nuclear/ Mineração. Disponível em: <http://www.inb.gov.br/pt-br/WebForms/interna.aspx?secao_id=81> Acesso em 2008.

International Society for Rock Mechanics (ISRM). 2007. The complete ISRM suggested methods for characterization, testing and monitoring: 1978-2006. In: Ulusay, R. \& Hudson, J.A. (eds.), suggested methods prepared by the Commission on Testing Methods, ISRM. Ankara, Turkey.

Irecereporter, 2014. CAA tem três projetos aprovados e irá construir milhares de tecnologias de Captação de água da chuva na Bahia. Disponível em: < http://irecereporter.com.br/noticia/caa-tem-tres-projetos-aprovados-e-ira-construir-milharesde-tecnologias-de-captacao-de-agua-da-chuva-na-bahia> Acesso em agosto de 2015.

Ivanovich M. \& Harmon R.A. 1982. Uranium-series Disequilibrium: Applications to Earth, Marine, and Environmental Sciences. Oxford, Clarendon Press, $571 \mathrm{p}$.

Jaeger, C. 1979. Rock Mechanics and engineering. $2^{\mathrm{a}}$ ed. Londres: editora Cambridge University Press.

Jesus, S.C. 2010. Levantamento dos níveis de radioatividade natural em águas do Alto Vale do Ribeira à Planície Costeira do Litoral Sul do Estado de São Paulo. Tese de Mestrado. Instituto de Pesquisas Energéticas e Nucleares, 157 p.

Kabata-Pendias, A.; Pendias, H. 1984. Trace Elements in Soil and Plants. Boca Raton, CRC Press Inc., 315 p.

Kuramoto, E. Mais urânio na cesta energética brasileira. ABEN- Associação Brasileira de Energia nuclear. Disponível em: < www.aben.com.br> Acesso em fevereiro de 2014.

Lobato L. M. 1985. Metamorphism, metassomatism and mineralization at Lagoa Real, Bahia, Brazil. Tese de Doutoramento, University Western Ontario, 306p.

Lobato, L. \& Fyfe, W. 1990. Metamorphism and mineralization at Lagoa Real, Bahia, Brasil. Econ. Geol., 5: 968-989.

Lobato, L. M., Forman, J. M. A., Fusikawa, K., Fyfe, W. S., Kerrich, R. 1982. Uranium Enrichment in Archean Basement: Lagoa Real, Brazil. Rev. Bras. Geoc., 1-3 : 484-486.

Lobato, L.M., Forman, J.M., Fuzikawa, K. Fife, W. 1983. Uranium enrichment in Archean basement: Lagoa Real, Brazil. Rev. Bras. Geoc., 21: 484-486. 
Maruèjol, P. 1989. Metasomatose alcalino et mineralization uraniferes: lês albitites du gisement de Lagoa Real (Bresil). Doctor of Philosophy Thesis, Centre de Recherches sur la Géologie de l'Uranium, 421p.

Maruèjol, P., Cuney, M., Fuzikawa, K., Maria Netto, A., Poty, B. 1987. The Lagoa Real Subalkaline Granitic Complex (South Bahia, Brazil): A Source for Uraniun Mineralizations Associated With Na-Ca Metassomatism. Rev. Bras. Geoc., 4: 578-594.

Matscullat, J., Ottenstein, R., Reimainn, C. 2000. Geochemical background - can we calculate it? Environmental Geology, v. 39, p. 990-1000,

Matsui, E. 1978. Origem e dinâmica da salinização de água do Nordeste brasileiro. Bacia do Rio Pajeú, PE. 164p. Tese de doutoramento - Escola Superior de Agricultura Luiz de Queiroz, Universidade de São Paulo, Piracicaba, 1978. 132p.

Mendes, B.V. 1997. Importância social, econômica e ecológica da caatinga: p. 72-121 In: Anais do Simpósio Brasileiro sobre Meio Ambiente e Desenvolvimento Sustentável do Semi-Árido, 1, Mossoró. Fundação Vingt-Un Rosado, CEMAD, Mossoró, RN. (Coleção Mossoroense, Série C, 948).

Nascimento, S.A.M. \& Barbosa, J.S.F. 2005. Qualidade da água do aquífero freático no alto cristalino de Salvador, bacia do rio Lucaia, Salvador, Bahia. Revista Brasileira de Geociências, 35(4):543-550.

Oliveira, A. M. S. e Brito, S. N. A. (eds) 1988. Geologia de engenharia. $1^{a}$ ed. São Paulo: editora Associação Brasileira de Geologia de Engenharia (ABGE), 587 pg.

Pádua, A.I.; Borges, W.R.; Cunha, L.R.; Lago, A.L.; Campos, J.E.G. 2013. Integração de dados geofísicos para a identificação de zonas fraturadas. Thirteenth International Congress of the Brazilian Geophysical Society.

Paul, G. \& Jungblut, C. 2008. Urânio: país pode quebrar monopólio. ABIN- Agência Brasileira de Inteligência. Disponível em: < www.abin.gov.br >. Acesso em fevereiro de 2009.

Pimentel, M.M., Machado, N., Lobato, L.M. 1994. Geocronologia U/Pb de rochas graníticas e gnáissicas da região de Lagoa Real, Bahia, e implicações para a idade da mineralização de urânio. In: SBG, Congresso Brasileiro de Geologia, 38, Boletim de Resumos Expandidos, p. 389-390.

Pires, F.R.M. 2012.Urânio no Brasil, geologia, jazidas e ocorrências. $1^{\text {a }}$ Ed. Rio de Janeiro: editora Vitrina Comunicação/ Eletronuclear.264p. ISBN 978-85-66024-01-2.

Planejamento Ambiental e Arquitetura - Estudo de Impacto Ambiental - EIA do Complexo Uranífero Mínero-Industrial de Lagoa Real, Caetité. Salvador: PLANARQ,1997.

Plumlee, G.S. 1999.The environmental geology of mineral deposits. In: PLUMLEE, G.S., LOGSDON, J.J. (eds.). The environmental geochemistry of mineral deposits. Part A, Processes, Techniques, and Health Issues. Society of Economic Geologists Reviews in Economic Geology, v. 6A, p. 71-116.

Raposo, C. \& Matos, E. C. 1982. Distrito uranífero de Lagoa Real- A história de um exemplo. In: SBG, Congresso Brasileiro de Geologia, 32, Anais, p. 2035-2047.

Raposo, C., Matos, E. C., Brito, W. 1984. Zoneamento cálcio-sódico nas rochas da província uranífera de Lagoa 1973. Real. In: SBG, Congresso Brasileiro de Geologia, 33, Anais, p. 1489-1502.

Rebouças, A. da C. 1973. Le problème de l'eau dans la zone seme-aride du Brésil: evaluation des ressouces, orientation pour la mise en valeur. Strabourg, 291p. Tese de doutorado. L'Université Louis Pasteur de Strasbourg.

Ribeiro, C. I., Carvalho Filho, C. A, Hashizume, S. 1984. As jazidas de urânio de Lagoa Real. Congresso Brasileiro de Geologia, 33, Anais, p.1463-1474. 
Santos, P., Azevedo, S. G., Mistreta, G. 1984. Novos Aspectos da salinização das Águas Subterrâneas do Cristalino do Rio Grande do Norte. IPT. Comunicação Técnica nº 314.

Scislewski, A. R. 2004. Estudo experimental da mobilidade do urânio por ação intempérica, Distrito Uranífero de Caetité/Lagoa Real, Bahia, Brasil. Tese de mestrado. Universidade Federal da Bahia.

Serra Junior, E.; Ojima, L. M. 1998. Classificação de maciços rochosos. In: Oliveira, A.M.S.; Brito, S.N.A. (ed.), Geologia de Engenharia. CNPQ/FAPESP, cap. 13, p. 211 a 226.

Siegel, F.R. 1979. Review of research on modern problems in geochemistry. Earth Sciences, United Nations Educational, Scientific and Cultural Organization, N.Y., vol. 16.

Silva, L.F. 2008. Geologia estrutural e geoquímica aplicados ao estudo do aquífero localizado na área do Complexo Mínero-industrial (URA/INB) de Caetité, Bahia. Monografia de Graduação, IGEO/UFRJ, 70 p.

Silva, L.F. 2009. A mineração de urânio no Brasil e o antagonismo entre o monopólio estatal e a função social da propriedade. Uma abordagem jurídico-geológica com vistas à participação da iniciativa privada. Monografia de especialização em sistemas mínero-metalúrgicos. Ouro Preto: UFOP-Fund. Gorceix-Vale. 87 p.

Silva, L.S. 2011. Avaliação da radioatividade natural em águas potáveis, de superfície e subterrâneas da região de Caetité, BA. Tese de mestrado. Instituto de Pesquisas Energéticas e Nucleares, $114 \mathrm{p}$.

Simões Filho, F.F.L.; Fernandes, H.R.S.M.; Franklin, M.R.; Flexor, J-M.; Fontes, S.L. Pereira Filho, S.R. \& Nascimento, F. 2003. Impactos de mineração e sustentabilidade no semi-árido. Estudo de caso: unidade de concentração de urânio - URA (Caetité, BA) in Anais do XV Simpósio Brasileiro de Recursos Hídricos, Curitiba, Nov. 2003, pp.1-20.

Simões Filho, F.L., Fernandes, H.M., Santos, R.R., Silva, L.F., Aravena, R., Pereira Fo, H.A. 2006. "Caracterização hidrogeoquímica, avaliação da qualidade e da recarga em aquíferos do semiárido associados a mineração de urânio (Caetité, BA)" In: XIV Congresso Brasileiro de ÁguasSubterrâneas, Curitiba, ABAS.

Simões Filho, F.L., Silva, L. F., Santos, R. R., Marques, A. J. 2008. Avaliação da contaminação de aquíferos fissurais através de modelagem geoquímica e levantamento estrutural em área de mineração de urânio no semiárido da Bahia. In: XV Congresso Brasileiro de Águas Subterrâneas, Natal/RN.

Siqueira, L. 1963. Aspectos hidrogeológicos do Cariri Paraibano.SUDENE, Bol. Rec. Nat., 1(1): 11-44.

Soares, T.M.; Silva, I. J. O.; Duarte, S. N.; Silva, Ê. F. F. 2006. Destinação de águas residuárias provenientes do processo de dessalinização por osmose reversa. Revista Brasileira de Engenharia Agrícola e Ambiental. Vol.10, $\mathrm{n}^{\circ} 3$.

Sobrinho, E. G., Raposo, C., Alves, J. V., Brito, W., Vasconcelos, T. G. 1980. O distrito uranífero de Lagoa Real, Bahia. In: SBG, Congresso Brasileiro de Geologia, 31, Anais., p. 1499-1512.

Stein, J. H., Netto, A. M., Drummond, D., Angeiras, A. G. 1980. Nota preliminar sobre os processos de albitização uranífera de Lagoa Real (Bahia) e sua comparação com os da URSS e Suécia. In: SBG, Congresso Brasileiro de Geologia, 31, Anais, p. 1758-1775.

Teixeira, J.A. \& Oliveira, S.P.B. 1962. Perfuração de poços tubulares e levantamento geológico, Petrolina PE. SUDENE, $22 \mathrm{p}$.

Teixeira, L. R. 2000. Relatório Temático de Litogeoquímica. Projeto vale do Paramirim. Salvador, CPRM/CBPM, 35p.

Tonetto, E.M. \& Bonoto, D.M. 2002. Mobilização de tório em águas subterrâneas de Águas da Prata, estado de São Paulo. Revista Brasileira de Geociências, v. 32, p. 343-350. 
Turpin, L., Maruèjol, P., Cuney, M. 1988. U-Pb, Rb-Sr and Sm-Nd chronology of granitic basement, hydrothermal albitites and uranium mineralization, Lagoa Real, South Bahia, Brazil. Contrib. Mineral. Petrol., 98: 139-147.

U.S. Geological Survey, The Advanced Spaceborne Thermal Emission and Reflection Radiometer (ASTER)/ Global Digital Elevation Model (GDEM). Desenvolvido juntamente com U.S. National Aeronautics and Space Administration (NASA), 2001. Disponível em: https://lpdaac.usgs.gov/dataset_discovery/aster/aster_products_table/astgtm Acesso em julho de 2015.

Webmineral, 2008. Uraninite Mineral Data. Disponível em: <http://www.webmineral.com/ data/Uraninite.shtml\#.VgL-a99VhBc> Acesso em Agosto de 2014.

Williams, A.R.; Kirchmann, R.J. 1990. Radium - a historical introduction. In: The Enviromental Behaviour of Radium, Technical Report Series, no 310, chapter.1, v.1, pp. 3-10, IAEA, Vienna.

Zhu C, Sverjensky, D.A. 1992. F-Cl-OH partitioning between biotite and apatite. Geochim Cosmochim Acta. 56:3435-3468.

ZimbresE. [citado 09 Dez 2005]. Disponível em: URL: http://www.meioambiente. pro.br/ agua/guia/aguasubterranea.htm. 